Juan Camilo Buitrago Trujillo

(Juan Buitrago)

\title{
ALADI, da libertação de nossos povos às leis do mercado
}

Tese apresentada à Faculdade de Arquitetura e Urbanismo da Universidade de São Paulo para obtenção do título de Doutor em Ciências em Arquitetura e Urbanismo.

Área de concentração: Design e Arquitetura

Orientador: Prof. Dr. Marcos da Costa Braga

Volume 1

São Paulo

2017

EXEMPLAR REVISADO E ALTERADO EM RELAÇÃO À VERSÃO ORIGINAL, SOB RESPONSABILIDADE DO AUTOR E ANUÊNCIA DO ORIENTADOR.

0 original se encontra disponível na sede do programa São Paulo, 15 de maio de 2017. 
AUTORIZO A REPRODUÇÃO E DIVULGAÇÃO TOTAL OU PARCIAL DESTE TRABALHO, POR QUALQUER MEIO CONVENCIONAL OU ELETRÔNICO, PARA FINS DE ESTUDO E PESQUISA, DESDE QUE CITADA A FONTE.

E-MAIL DO AUTOR: buitraguillo@gmail.com

Buitrago Trujillo, Juan Camilo

B932a ALADI, da libertação de nossos povos às leis do mercado / Juan Camilo Buitrago Trujillo. -- São Paulo, 2017.

2 v, 488 p. : il.

Tese (Doutorado - Área de Concentração: Design e Arquitetura) FAUUSP.

Orientador: Marcos da Costa Braga

1.Design - América Latina 2.Historia do design 3.Sociologia do design 4. Asociación Latinoamericana de Diseño - ALADI I.Título 
Nome: Buitrago, Juan

Título: ALADI, da libertação de nossos povos às leis do mercado

Tese apresentada à Faculdade de Arquitetura e Urbanismo da Universidade de São Paulo para obtenção do título de Doutor em Ciências em Arquitetura e Urbanismo. Área de concentração: Design e Arquitetura

Aprovado em:

Prof. Dr.

Instituição:

Julgamento:

Prof. Dr.

Instituição:

Julgamento:

Prof. Dr.

Instituição:

Julgamento:

Prof. Dr.

Instituição:

Julgamento:

Prof. Dr.

Instituição:

Julgamento: 
À Bibi, pela paciência e a cumplicidade. Porque eu já sei qual é a palavra... é attraversiamo! 


\section{Agradecimentos}

[...] O vaivém é também geográfico, percorrendo espaços entre São Paulo, Buenos Aires e Montevidéu [acrescentaria para meu caso: Bogotá, Medellín, Cidade do México, Havana e Rio de Janeiro]. Nesse sentido, e como no famoso mapa de Joaquín Torres García, meu sul se converteu em meu norte. Jorge Schwartz (Brasil) (Schwartz, 2013, p. 10).

A pesquisa de onde proveem as seguintes ideias, me permitiu dar uma resposta provisional para o fenômeno da ALADI que me inquietava desde tanto tempo atrás. A Universidad del Valle o possibilitou pela "Comisión de Estudios" que me outorgou para fazer o meu doutorado na Universidade de São Paulo -USP-. A USP, por sua vez, me recebeu e ofereceu a estrutura de uma universidade de primeiro nível. Um valor que tomara não seja perdido no assédio político que vive 'o público' atualmente o Brasil, e que, oxalá, seja conquistado na Colômbia na conjuntura de mudança de narrativa social: a formação gratuita de qualidade em todos os níveis é preciso para a América Latina do pesadelo. Sou orgulhoso de ser parte dos doutores egressos da USP. Agradeço também à Fundação do Amparo para a Pesquisa do Estado de São Paulo -FAPESP-, que avaliou que o meu projeto era digno de ser apoiado. A generosa bolsa que recebi dela foi fundamental para a consecução dos objetivos.

Serei permanentemente grato com todos aqueles que me outorgaram depoimento em cada país que visitamos. Conhece-los logo de anos de familiaridade com os seus nomes é místico. Todos foram cálidos e muito amáveis. Especialmente serei grato com Franca Rosi em Montevidéu; José Abramovitz e Luiz Blank no Rio de Janeiro; Santiago Pujol em Havana; Oscar Hagerman, Oscar Salinas, Gabriel Simón e Claudio Rodríguez na Cidade do México; assim como com Karen Lange, Jairo Acero, Jesús Gámez e Rómulo Polo em Bogotá. Cada um deles cedeu para mim copias e até originais de documentos dos seus acervos pessoais, enriquecendo as minhas fontes primárias. Salinas além disso me conectou com muitas pessoas, tanto no México como em Cuba. Por sua parte, Lesley Whitworth em Brigthon, assim como Neil Parkinson em Londres me permitiram experiências cativantes de arquivo. Lesley no Design Arquives da Universidade de Brigthon aonde repousa o acervo do ICSID -International Council of Societies of 
Industrial Design-; Neil no Archives \& Collections do Royal College of Arts que atesoura processos sediados nessa instituição e que são tão importantes para a profissionalização do design. No Design Arquives consegui vários documentos imprescindíveis para a pesquisa. No Archives \& Collections não tanto para essa pesquisa, mas sim para perguntas posteriores. Aproveito para agradecer a Lívia Rezende que me abriu as portas do Royal College e me apresentou a Neil.

Nessa mesma direção sou grato com Gabriel García em Bogotá, que me contatou com vários colegas relacionados com os processos da ALADI tanto na Colômbia, quanto na Guatemala. Por sua vez Elina Pérez foi generosa me enviado documentações desde Caracas. Aqueles documentos relatam alguns dos processos da ALADI na Venezuela, contribuindo à necessária perspectiva nas questões da associação desde finais dos anos 1980 e inicio dos 1990. Já em Buenos Aires Ricardo Blanco foi muito amável me contatando com os seus antigos colegas, todos eles relacionados em diferentes níveis com a ALADI. Graças a esses contatos consegui fazer entrevistas essenciais para a pesquisa na Argentina.

Sou igualmente grato com Beatriz Castro. Em principio por todas aquelas coisas que já tinha aprendido dela sobre a critica histórica e sociológica. Várias dessas ideias conversaram comigo durante essa pesquisa. Porém explicitamente lhe agradeço pela generosidade de conceito que escreveu para eu aplicar à bolsa da FAPESP. Me convenço de que as suas considerações deram confiança nos pareceristas que decidiram me outorgar a bolsa. Agradeço também à Priscila Farias por essa generosidade.

A ideia que originou esse argumento foi sonhada, desenhada, projetada, possibilitada e finalmente desenvolvida, graças à importantíssima participação de uma inúmera quantidade de eventos e pessoas. Desde a minha primeira aproximação nela em Bogotá em 1998 ou 1999, quando -por causa de uma mudança no escritório no qual trabalhava quando estava em férias universitárias- apareceram nas minhas mãos copias de duas revistas. A primeira se chamava "La Carreta del Diseño", uma pequena publicação de 1980 feita na cidade, por quatro grandes nomes do design colombiano: Jaime Gutiérrez, Hernán Lozano, Jesús Gámez e Rómulo Polo. Era uma publicação que recolhia artigos de cada um deles e alguns outros designers, sobre a discricionalidade e a jurisdição do design... sobre o que é e para que funciona isso no contexto colombiano. A segunda revista se chamava "Módulo", sendo editada por Franca Rosi e Oscar Pamio na cidade de Cartago na Costa Rica. Essa revista coletava artigos de vários nomes do design 
na extensão da América Latina, entre os quais estavam aqueles colombianos de "La Carreta". Se encontrar escritos de colombianos pensando o design foi incrível, vê-los em diálogo com os seus colegas da região fazendo a mesma coisa me pareceu assombroso. $\mathrm{Eu}$ tinha passado recentemente por aulas de história do design que me deixaram grandes inquietações. Narrativas que me produziram grandes moléstias pelo que compreendo hoje como a resignação e a repetição acrítica de histórias de exaltação e influencia internacional, para explicar o que acontece entre nós. Como se só existíssemos sendo um reflexo. Não porque acredite que 'o internacional' não tem nada a ver com o que aconteceu no país e na região, mas pelo fato de que as interpretações sobre a sua influência, tinham sido realmente desproporcionadas -exageradas- e descontextualizadas, resignando a nossa possibilidade de compreensão.

As duas revistas nas minhas mãos compartilhavam um mesmo bloco de informações que me deixou ainda mais deslumbrado. Elas traziam documentos que davam conta da existência de uma associação de designers que tinha sido fundada em Bogotá em 1980 por delegações de nove países da região. Não só era mencionada com alegria e orgulho a fundação. Elas incluíam a ata fundacional, e no caso de "La Carreta", até os documentos redigidos em cada passo que se seu para chegar em Bogotá: estava completamente alucinado. Da sua generosidade por anos de conversas e de cedências de documentação e interpretações, sou e serei grato com Rómulo Polo. Ele não só foi o primeiro presidente daquela associação chamada ALADI, mas era o dono desse escritório aonde eu trabalhava quando descansava da rotina de faculdade.

Desde esse momento as minhas inquietações com a ALADI me rondavam. Mas porquê? 0 que tiveram aqueles documentos que despertaram esse nível de interesse em mim? Muitas outras coisas passaram pelas minhas mãos e, simplesmente seguiram o seu caminho. Porquê essas ficaram, além, naquele nível?

Em parte me aproximo à resposta, quando tento me ver reflexado no espirito da Associação. Durante a minha adolescência construí o gosto por umas determinadas coisas que fizeram de mim o que sou agora. Naquela época decidia por exemplo fumar "Mustang rojo" em lugar de "Marlboro" assim como beber o refrigerante chamado "Colombiana" e não "Coca-Cola". Decidi comer hambúrguer em "El Corral” e não em "Mcdonalds". Parece tonto -em verdade e em parte é- mais essas e outras coisas que decidia fazer na companhia dos meus antigos e igualmente tontos amigos, é um sintoma do que encontrei na ALADI. Guardando as proporções, quando eu escolhia um produto 
colombiano acima de um norte-americano na "tienda" do meu bairro, inconscientemente decidia pela quebra da dependência, castigando o snobe e o arrivismo, significando dependência, snobe e arrivismo o que significasse. Eram decisões como as que me invitavam a torcer por um time latino-americano em lugar de um europeu na Copa do Mundo de futebol de 1994 ou de 1998. Fazer essa pesquisa e escrever as ideias que apresento nesse texto, permitiu me conhecer mais um pouco, tentando compreender o porquê me emociono com determinadas coisas e me incomodo com outras.

Por outro lado na sua forma, meu pai e a minha avó -a mãe da minha mãeconseguiram me apaixonar pelos relatos de Gabriel García Márquez desde a minha infância. Lembro por exemplo, algumas das conversas com ela, nas quais me descrevia e até lia passagens de "Cem anos de solidão", o "Amor nos tempos do cólera" ou "O general em seu labirinto". Era emocionante mesmo ver como ela parecia se transportar. Sendo um precoce adolescente não conseguia compreender o sentido do que García Márquez tratava naquelas narrações. Dessa forma, quando encontro no coração do discurso de García Márquez -na sua própria forma ilustrada- a minha reclamação, encontro uma dupla conexão emocional com a sua obra: uma que me liga às letras por minha avó e a sua própria linha de estímulo social com a leitura; outra que me explica que ele reivindicava aquele espirito que encontrei atesoirado na ALADI e que me comove ainda como discurso de dignidade e solidariedade.

No inicio mencionei que sou grato com uma longa lista pessoas. Em primeira instancia meu orientador Marcos Braga. Conversas sobre história do design brasileiro, suas organizações e apostas, deram perspectiva a várias interpretações da minha pesquisa. Da mesma forma lhe agradeço pela sua paciência com meu português atrapalhado que -ainda cada vez foi melhor- estou convencido que nunca esteve no lugar da comunicação concreta com a que se relacionam na vida acadêmica no Brasil. Ele igualmente abriu a porta para a minha participação em vários cenários como o PAE Programa de Aperfeiçoamento do Ensino- ou o Seminário Paulista de Ensino da História do Design. Contudo o que valoro mais do que qualquer coisa é a sua ajuda para ter moradia em São Paulo, o que foi possível também pela generosa ajuda da sua mulher: Ângela Cardoso. Marcos e Ângela permitiram que a nossa estancia inicial fosse tranquila em um país aonde nem se fala a minha língua materna. Obrigado aos dois.

Nessa mesma linha sempre serei grato com Maryuri Mora e Carlos Beltrán, que abriram as portas da sua casa em São Bernardo do Campo para nós receber. Se não 
tivesse sido por eles, as coisas houvessem sido muito difíceis para nós. Mary além com a cumplicidade de Humberto Ramos e Raquel Lima fizeram com que a minha documentação no Brasil se agilizasse para iniciar a viagem.

Nesse processo também conhecemos a Josh e Kimberly Vis, com os que compartilhamos momentos significantes para mim. Antes da sua viagem de regresso para os Estados Unidos -moraram no Brasil dois anos- eles deram praticamente o seu mobiliário de casa para nós, com o qual vivemos em São Paulo. As diferentes preocupações deles com a nossa tranquilidade ultrapassam a ideia do interesse, me deixando ver que a solidariedade -cooperação nas teses de Sennett- é um valor que governa as relações humanas, podendo ultrapassar os marcos da conveniência. É possível estar aí, no presente e se colocar realmente no lugar do outro. Com todas as limitações para nós comunicar, eles e nós estabelecemos uma relação 'não logica' embasada nas estruturas do linguaje verbal-, mas altamente significativa. A pesar de todas as distancias existentes que iniciavam com a língua, essa vontade por estar presentes, permitiu que compartilhássemos momentos inesquecíveis que moram na minha memória.

Duas grandes amigas merecem meu mais aprofundado agradecimento. Por uma parte Adriana Guzmán que me acompanhou esses quatro anos de assuntos administrativos em Univalle, indo, recebendo e atendendo a interminável listagem de apetites burocráticos da Universidade. Na sua vez Dora Dias, quem aliás de tudo o que a cotidianidade permitiu em São Paulo, me incentivou e acompanhou para conseguir a bolsa da FAPESP, assim como revisou e corrigiu generosamente esse escrito, dando claridade nesse meu esquisito português.

Estando em São Paulo senti falta das tertúlias com o meu caro Fernando Flórez. Aquelas conversas em torno da mimeses, das formas como se produzem e reproduzem os processos culturais; as formas que adquirem os discursos, as suas estruturas, as logicas às que aparentam responder, etc., todo aquele arsenal de ideias que apareciam nas nossas tertúlias. Estou convencido de que várias das coisas que debatíamos, estão presentes no enfoque desse trabalho.

María Fernanda Muñoz, me ajudou a focar em um momento em que precisava perspectiva. As diferentes epifanias que promoveu, permitiram que retomasse confiança nas minhas ideias que, as vezes, por conta da bruma com que a vida se apresenta, pareciam se esfumar. Uma das conquistas mais importantes da vida -quem sabe se a 
mais- é a de perder o medo a se conhecer. Quero pensar que esse caminho o iniciei, e foi, na companhia de Mafa.

Nessa linha o meu agradecimento por meus caros e antigos amigos é gigante. Desde o momento em que iniciei o meu percurso como professor na Universidad del Valle -2005- foi se dando uma relação que mistura camaradaria e cumplicidade, com rigor e paixão pelo debate e a critica. Nesses quatro anos que morei em São Paulo, senti muita falta da sua companhia. Senti falta da sua camaradaria, da sua cumplicidade e descarnada crítica. Me aproprio das palavras de García Márquez quando penso em Tatiana Cuellar, Diana Valero, Miguel Bohórquez, Andrés Reina e Mauricio Chemás: “Mi mayor satisfacción no es haber ganado tantos y tan maravillosos amigos nuevos, sino haber conservado, contra los vientos más bravos, el afecto de los más antiguos". Vocês estão presentes nas minhas meditações.

De Cuba meu coração saiu pequeno. A ajuda de Gisela Herrero, Alejandro Ojeda e Jenny García foram cruciais para a pesquisa me acompanhando na revisão do acervo inativo da ONDI -Oficina Nacional de Diseño- aonde praticamente repousa a memória institucional da ALADI. Agradeço a Gisela que promoveu a minha consulta lá. Lucila Fernández foi igualmente importante para a nossa instancia em Havana: foram intensas e emocionantes as nossas conversas abraçadas pela magia do verão caribenho. Sergio Peña com natural sensibilidade promoveu a minha consulta na Biblioteca do Instituto Superior de Diseño em Havana. Idania Ramos -obrigado com a minha querida Paulina Avellaneda que me conectou com ela-, nos contatou com Patria e Noemi Rivera. Elas por sua vez nos receberam na sua casa durante a nossa estadia na ilha. Permanentes e variadas conversas tivemos à luz dos acontecimentos da região. Desde o -nesse momento possível- impeachment de Dilma no Brasil, passando pelas aproximações entre Raúl Castro e Barack Obama até chegar na realidade do processo de paz entre o governo colombiano e as FARC, que nesse preciso instante estava em negociação alguns quilômetros ao norte de donde conversávamos. Quando digo que meu coração saiu pequeno da ilha está relacionado com ter conhecido pessoas como todos eles. Contudo Patria e Noemi conquistaram o nosso coração com a sua grandeza. Dedico as letras desse escrito para vocês com toda a minha gratidão.

No México a experiência foi indescritível. Caminhar pelo D.F, sobre tudo pelo seu centro é sentir que um grande e antigo ancestre mora no ambiente. 0 estado atual do “Templo Mayor” é em si uma metáfora. Lá tudo foi extraordinário porque Itzia Guzmán e 
Philip Nevin nós receberam e dividiram sua cotidianidade. A camaradagem que conseguimos estabelecer, em sentida sensibilidade com as vivencias da arte, do design, da política; a comida, a musica, os vinhos... Eles são grandes. São bons amigos. São irmãos. Georgina Morales e Javier Guzmán; Pilar Bordes e Paul Nevin pais deles, nos acolheram como sendo parte da sua família. Na mesma direção sou grato com Iris López. Com ela sempre haverá cumplicidade para dar gargalhadas e experimentar comidas maravilhosas. Sua companhia em São Paulo foi importante para o que passávamos no momento. 0 tamanho da sua bondade pode ser medido pela sua sensibilidade... pela sua capacidade de se colocar no lugar do Outro no momento respectivo. Obrigado Iris.

Na Argentina a companhia e conversas com Verónica Devalle -como sempreforam irreverentes e estimulantes. Ela teve a sensibilidade de me convidar no Instituto de Arte Americano e Investigaciones Estéticas da Universidade de Buenos Aires: o que é todo um honor. Dentro dos meus assistentes estevem Daniela Lucena, Laura Zambrini, Paulo Ledesma e o próprio Mario Sabugo -plateia de primeiro nível-, para mencionar só alguns. Buenos Aires vira no tempo uma cidade encantadora, que vai mobilizando sentimentos profundos e três pessoas fizeram daquela estância uma lembrança marcante. Em primeira instancia Claudio Guerri, quem nós recebeu no seu lar, logo do qual nós levou para a sua casa no "Tigre" fazendo um assado na beira do rio, que simplesmente ficou gravado no profundo dos meus registros aromáticos e gustativos: indelével. Que grandeza Claudio! As outras duas pessoas são Vicky Avendaño e Paulo Ledesma. A nossa corta vida em Buenos Aires foi linda, porque conseguimos compartilhar a cotidianidade com eles. Nós mostraram cantos da "Ciudad de la furia"; vivenciamos juntos a desilusão do voto do NÃO no Plebiscito pela Paz; choramos, rimos, comemos, bebemos e conversamos por horas. Moram no nosso coração.

No Uruguai tivemos uma experiência igualmente estimulante. Viajamos para lá expressamente para entrevistar Franca Rosi e não foi em vão. A conversa com ela foi uma das melhores que teve na pesquisa pelas relações diversas entre assuntos. Como se a entrevista fora pouca coisa, ela nós recebeu com uma total amabilidade e uma desprendida gentileza culinária.

Já na Colômbia tudo foi bom pela presencia incondicional da minha família. Meu pai e o seu carinho e alegria por viver -ele praticamente financia parte da pesquisa ao me emprestar o seu cartão de crédito-; minha mãe, sua hospitalidade e carinho, Monica com a sua cumplicidade e Camila com o seu talento; meu cunhado Enrique Arévalo - 
parceiro e cúmplice- e Silvana e Violeta, as minhas lindas sobrinhas. Ambas -Silvana e Violeta- mexeram no meu coração em momentos muito particulares da minha vida, mostrando sentido em momentos difíceis. Com algo de esoterismo -aceito- acredito que boa parte da capacidade que possa ter para me focar no importante -núcleo do fato de ter resolvido essa tese-, se deve a cada uma dessas sacudidas... àquelas palavras, miradas e/ou gestos.

Em Bogotá, principalmente na Universidade Jorge Tadeo Lozano estou agradecido com meu caro amigo Pedro Duque, que sempre se tinha mostrado parceiro com os meus processos. Lá igualmente me recebeu Diana Castelblanco para ministrar três palestras sobre a minha pesquisa. Abrir espaço para esse debate foi importante para organizar partes da tese. Abro um parêntese: a esses espaços na Tadeo e na UBA, devo somar aquele que criou Gisela Belluzzo de Campos na Universidade Anhembi Morumbi em São Paulo. Ela avaliou que uma palestra sobre a minha pesquisa seria útil para o seminário de Doutorado em Design que coordenava. Essa palestra me permitiu arrumar vários pontos que por sua vez me facilitou a escrita do capitulo 3. Fechando a parêntese, em Bogotá também conversei de várias ideias com Renán Silva. Discutimos vários ângulos do assunto da minha pesquisa, relacionados principalmente com problemas de enfoque e de procedimento. A claridade com que Renán compreende a análise sociológica deu força para organizar e projetar os processos da última parte da pesquisa e sou muito grato com ele.

Já em Medellín meu total agradecimento é com meu caríssimo amigo Augusto Solórzano. Como se o fato de me ceder a memória da primeira ALADI lá pelo 2010 tivesse sido pouco, ele abriu as portas da sua casa para nós hospedar uns dias. Não só pelas conversas daqueles dias e as suas noites, mas pelas que tivemos inúmeras vezes enquanto morei no Brasil, eu estou em franco agradecimento com ele. Para mim Augusto coincide com aquela clássica imagem do filósofo que descobre -ou ilumina- os assuntos dando perspectiva para as decisões da vida. Enquanto morei em São Paulo, lembro pelo menos de duas decisões cruciais que tomei logo que adquiriram perspectiva graças ao Augusto.

No Brasil, além de Dora conseguimos conhecer e estabelecer uma amizade sincera com Patricia Amorim e Raúl Aguiar. Eles são parceiros de viagem, de ideias e de sonhos. São estimulo para o trabalho e um grandíssimo apoio emocional na nossa estancia em São Paulo. Dividimos risos, gracejos e pensamentos... compartilhamos natais... vimos 
como viraram os anos... comemos e bebemos... fomos camaradas e nós abraçamos. Parceiros e amigos. Moram na nossa alma.

Mas no final, eu não tivesse tido coragem suficiente nem paciência para terminar essa pesquisa cumprindo prazos e formalismos burocráticos, mas sobretudo respondendo para mim essa pergunta de tantos anos, se não tivesse sido pela cumplicidade, o carinho e a paciência da minha admirável e corajosa Bibi. Com toda razão Idaina em Havana diz que a pesquisa é dos dois. Se o trabalho foi desenvolvido entre arepas, acarajés, tacos al pastor, tapiocas e fainás... entre empanadas, tamales, hayacas e pamonhas... entre o carinho de mergulhar acervos e conhecer gente boa... entre falar espanhol e português -até inglês-... entre caminhar pelas ruas de São Paulo, Rio de Janeiro e Porto Alegre, Buenos Aires e La Plata, Montevidéu, Cidade do México e Teotihuacán, Bogotá, Medellín e Havana, Londres, Aberdeen e Brigthon... se tudo isso foi grande, a maior satisfação foi fazê-lo e compartilha-lo contigo. Assim como diríamos em espanhol: te dedico las siguientes letras. 


\section{Resumo}

Buitrago, Juan. ALADI, da libertação de nossos povos às leis do mercado. 2017. 488 f. Tese (Doutorado) - Faculdade de Arquitetura e Urbanismo, Universidade de São Paulo, São Paulo, 2017.

Em Bogotá, Colômbia, delegações de nove países latino-americanos, fundaram ALADI (Associação Latino-americana de Designers). Acima de um nítido discurso de reivindicação cultural, os fundadores da ALADI conceitualizaram o Design dentro do campo da tecnologia, como a ferramenta mais adequada para a conquista da autonomia industrial, econômica e cultural dos 'nossos povos'. O discurso fundacional lutou por prevalecer durante os anos 1980, enquanto a associação iniciava o seu fortalecimento em meio das complicações da chamada "década perdida". Com determinados sucessos e problemas o esquema inicial da associação chega aos anos 1990, quando vai mudar de sentido e poder de convocação, exatamente no momento em que América Latina conhece a face mais crua do neoliberalismo. A partir do estudo de fontes documentais e entrevistas com os atores do processo, esta pesquisa pretende determinar as condições sociais que explicam a criação, o funcionamento e a mudança da ALADI entre 1978 e 1995, sendo a pegada de uma epistemologia do design particular -até o momento não levada em conta- que é pensada na América Latina, para a América Latina.

Palavras-chave: 1. Design - América Latina 2. Historia do design 3. Sociologia do design 4. Asociación Latinoamericana de Diseño - ALADI I. Título 


\section{Abstract}

In Bogota, Colombia, delegations from nine Latin American countries, founded ALADI (Latin American Design Association). Above all, the founders of ALADI conceptualized Design within the field of technology as the most appropriate tool for the conquest of the industrial, economic and cultural autonomy of 'our peoples'. The foundational discourse struggled to prevail during the 1980s, while the association began its strengthening amid the complications of the so-called "lost decade." With certain successes and problems the initial scheme of the association comes to the 1990s, when it will change its meaning and power of convocation, just at a time when Latin America knows the cruder face of neoliberalism. From the study of documentary sources and interviews with the actors of the process, this research intends to determine the social conditions that explain the creation, operation and the change of ALADI between 1978 and 1995, being the footprint of a epistemology of a particular way of see design -until not taken into account- that is thought in Latin America, for Latin America.

Keywords: 1. Design - Latinamerica 2. History of design 3. Sociology of design 4. Asociación Latinoamericana de Diseño - ALADI I. Title 


\section{Resúmen}

En Bogotá, Colombia, delegaciones de nueve paises latinoamericanos, fundaron ALADI (Asociación Latinoamericana de Diseñadores). Basada en un contundente discurso de reivindicación cultural, los fundadores de ALADI conceptualizaron el Diseño dentro del campo de la tecnologia, como la herramienta más adecuada para la conquista de la autonomia industrial, económica y cultural de 'nuestros pueblos'. El discurso fundacional luchó por prevalecer durante la década de 1980, mientras la asociación iniciaba su fortalecimento en medio de las complicaciones de la llamada "década perdida”. Con determinados logros y problemas, el esquema inicial de la asociación llega a los años 1990, quando parece cambiar de sentido y debilitar su poder de convocatoria, exactamente en el momento en que América Latina conoce la faceta más cruda del neoliberalismo. A partir del estudio de fuentes documentales y entrevistas com los actores del proceso, esta investigación pretendió determinar las condiciones sociales que explican la creación, el funcionamiento y el sugerido cambio de ALADI entre 1978 e 1995, siendo ella misma, la huella de la existencia de una epistemologia del diseño particular -hasta ahora no tenida en cuenta- que fue pensada en América Latina, para América Latina.

Palabras clave: 1 . Diseño - América Latina 2. Historia del diseño 3. Sociologia del diseño 4. Asociación Latinoamericana de Diseño - ALADI I. Título 


\section{Sumário}

\section{Introdução}

O design é pensado na terra de pássaros berrantes, ditadores e populismos nacionalistas, 19 Aproximações à ALADI, 23

Questões, fontes e procedimentos, 26

A minha infraestrutura, 32

\section{Parte 1}

\section{Capítulo 1. 0 design nessa periferia, 39}

Entradas na modernidade

Uma revolução de irreverentes, 42

Proveniências e desprendimentos, 52

Um projeto emancipador

A velha toupeira, 62

Caixas de ressonância, 72

Sem querer querendo?, 81

A união faz... besteira!, 93

\section{Parte 2}

Capítulo 2. Origens e fundação, 104

Véspera, completas, matinas e prima

Ahmedabad e Bombaim, janeiro de 1979, 107

Sensibilização nacional, 109

0 pacto das catacumbas, 111

Medellín, 1980, 116

Um amanhecer de vinte quatro meses, 116

Não, brief não

Uma estrutura para a interação, 120

Design e tecnologia adequada, 122

Exotismo e identidade, 129

Faces de uma mesma moeda, 132

Duas trajetórias... duas pegadas estendidas, 136

Uma joia no caminho!, 140

0 manifesto, 146

0 assedio dos intrusos

Entrando em Macondoamérica, 149

Vamos de safari!, 151

Ajudar os desfavorecidos, 154

E ai?, 157

A Guerra Fria da Cultura, 161

Capítulo 3. Santandercito e Bogotá: o design segundo a América Latina, 163

Várias ALADIs no âmago da ALADI

Fórum dos fóruns, 165

Senso comum, 167

Heterogeneidade, o design industrial na América Latina, 172

Jurisdição e discricionalidade do design latino-americano, 175

0 sentido... a sua função, 176

Geografias, 182

Designer latino-americano como o protótipo de homem ilustrado, 186

Design e circunstâncias, 190

Quebrar o imperialismo, 191 
Design nas circunstâncias, 199

Essencialmente distintos, 203

Design e subdesenvolvimento, 206

Matrizes de desigualdade, 207

Propósitos falseados, 211

Copia y royalties: dependência, 216

Elementos de una comunidade, 219

Capítulo 4. ALADI, uma comunidade interpretativa, 225

Criatividade social

Criar para resolver, 228

Criar para satisfazer, 238

Tecnologia e circunstâncias

Espelhos da miséria, 248

'Povocentrismo', 251

Industrialização como desejo

A disciplina das práticas, 257

0 progresso técnico como caminho para a prosperidade, 264

Teoria da dependência e diálogo com a esquerda nacionalista, 266

o Povo de Deus e a ampliação da ideia de pecado

Solidariedade e status quo, 275

Um catolicismo latino-americano?, 277

Ação pastoral e autonomia, 283

América Latina, uma Comunidade Imaginada

Não saxã, latina!, 292

O povo como nação, 298

"O tamanho da nossa solidão", 304

\section{Parte 3}

Capítulo 5. Quinze anos na década perdida, 322

Estruturas em ajuste, 323

Espectros em desencantamento, 325

Caravelas desaparecidas, 336

Uma cabeça sem corpo

Voamos muito alto..., 349

Pneûma, 359

Três lustros e as suas desilusões, 369

Capítulo 6. Das utopias ao mercado, 376

Linhas enfraquecendo

Traços da transição, 378

Modernismo fordista, 383

o Grande Estado e a síndrome da eficiência

Modernismo exuberante, modernização deficiente, 388

Década comprida e transições, 400

Após 75 anos, acaba o século 20 curto, 411

Uma frágil consolidação, um desmanchamento anunciado

Do discurso nacionalista ao discurso da eficiência, 422

Dos sonhos à apatia. Todo o sólido desmancha no ar, 435

\section{Ebriedades e desencantos (considerações finais), 440}

Uma experiência em perspectiva, 442

0 inconsciente coletivo e a comunidade interpretativa, 454

Da criatividade social às leis do mercado, 461 


\title{
Abreviaturas e siglas
}

\author{
ABDI Associação Brasileira de Desenho Industrial (Brasil) \\ ACD Asociación Colombiana de Diseñadores \\ ACD Australian Design Council \\ ADIA Asociación de Diseñadores Argentinos \\ ADIBA Agrupación de Diseñadores Industriales de Buenos Aires (Argentina) \\ ALADI Asociación Latinoamericana de Diseño \\ AMDAC Asociación Mexicana de Diseñadores A.C. \\ ANIEDI Asociación Nacional de Instituciones de Enseñanza del Diseño Industrial (México) \\ APDINS Associação Profissional dos Desenhistas Industriais de Nível Superior (Brasil) \\ APDINS/PE Associação Profissional dos Desenhistas Industriais de Nível Superior de Pernambuco \\ APDINS/RJ Associação Profissional dos Desenhistas Industriais de Nível Superior de Rio de Janeiro \\ BID \\ CADI \\ Banco Interamericano de Desenvolvimento \\ CAPES \\ CAYC \\ Comité Argentino de Diseño Industrial \\ Coordenação de Aperfeiçoamento de Pessoal de Nível Superior (Brasil) \\ CELAM \\ Centro de Arte y Comunicación (Argentina) \\ CEPAL \\ CIA \\ Conselho Episcopal Latino-Americano \\ Comisión Económica para América Latina y el Caribe \\ Central Intelligence Agency (EUA) \\ CIDI \\ CNA \\ Centro de Investigación del Diseño Industrial (Argentina) \\ CNPQ \\ Comité Nacional de ALADI \\ CODIGRAM \\ Conselho Nacional de Desenvolvimento Científico e Tecnológico (Brasil) \\ DIITPN \\ DIMAC \\ Colegio de Diseñadores Industriales y Gráficos de México \\ Diseñadores Industriales de México A.C. \\ ECOSOC United Nations Economic and Social Council \\ EDII \\ ELN \\ ENBA \\ ENDI \\ ESDI \\ FAO \\ FARC \\ FIESP \\ HFG \\ IAPI \\ IBERO \\ ICA \\ ICIODI \\ Escuela de Diseño Industrial e Informacional (Cuba) \\ Ejército de Liberación Nacional (Colômbia) \\ Escola Nacional de Belas Artes (Brasil) \\ Encontro Nacional de Desenho Industrial (Brasil) \\ Escola Superior de Desenho Industrial (Brasil) \\ Organização das Nações Unidas para a Alimentação e a Agricultura \\ Fuerzas Armadas Revolucionarias de Colombia \\ Federação das Indústrias do Estado de São Paulo (Brasil) \\ Hochschule für Gestaltung (cidades alemãs de Ulm e Offenbach) \\ Instituto de Aposentadoria e Pensões dos Industriários (Brasil) \\ Universidad Iberoamericana (México) \\ International Cooperation Administration (EUA) \\ ICOGRADA International Council Of Graphic Design Associations \\ ICSID International Council Societies of Industrial Design \\ ICT Instituto de Crédito Territorial (Colômbia) \\ ICU Istituto per la Cooperazione Universitaria (Italia) \\ IDCA Industrial Design Council of Australia \\ IDI Instituto de Diseño Industrial de la Universidad de Rosario (Argentina) \\ IES Institução de Educação Superior \\ IMCE Instituto Mexicano de Comercio Exterior
}




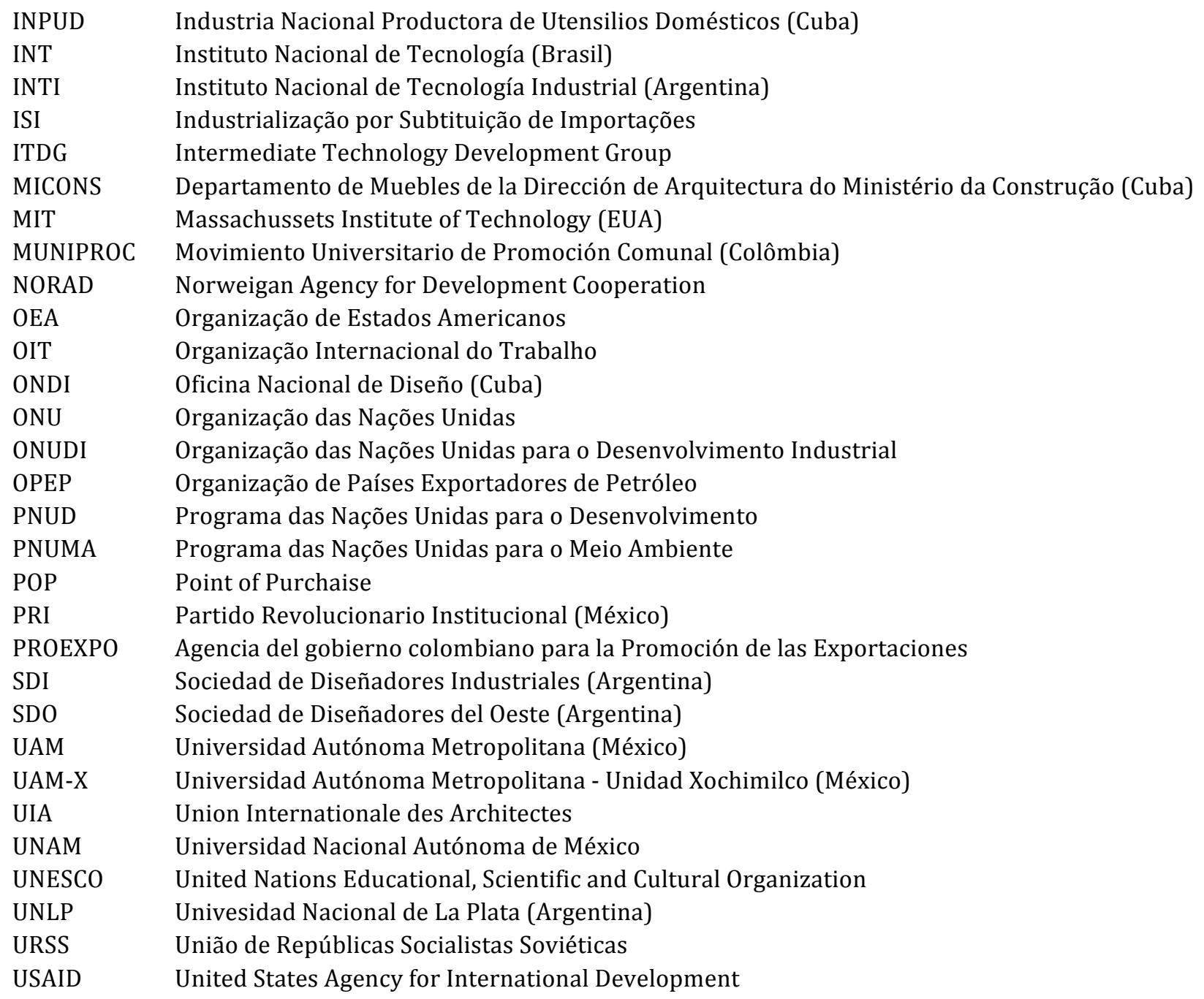




\section{Uma voz latino-americana do design}

[...] Quizá la baja calidad armónica de nuestros pájaros [diz Brunner] no se deba tanto al calor tropical como al hecho de que los habitantes de la selva tenían voces chillonas [...] "el dia que [diz o ilustríssimo Hegel] dejen de oirse en las selvas del Brasil los sonidos casi inarticulados de hombres degenerados, ese día muchos de los plumíferos cantores producirán también melodias más refinadas" [se pergunta Brunner] ¿Qué significado podemos atribuir a tales lecturas "comparativas" de la historia de las culturas, donde finalmente siempre tendrá que concluirse que, respecto del modelo predominante, a las demás -las culturas subordinadas o periféricas- les faltan atributos como la voz cantarina o un Voltaire y les sobran por el contrario, plumas y dictadores? (Brunner, 1995, p. 280).

\section{o Design é pensado na terra de pássaros berrantes, ditadores e populismos nacionalistas}

1.

É mais ou menos evidente que durante os anos 1970 livros especializados em design começam a ser publicados na Europa e nos Estados Unidos. Isso é explicável por várias razões sendo uma delas, seguramente, a proximidade que as grandes associações internacionais de designers estabeleceram com casas editoriais como Gustavo Gili. Muitos dos que participaram dos boards no ICSID, por exemplo, acabaram publicando seus primeiros escritos por meio dessa editora durante esse período. Porém, esse fenômeno significando uma multiplicação importante da reflexão do design naqueles lugares, não implica que em outras partes esse movimento não estivesse ocorrendo, até mesmo antes desse período. Por exemplo, na América Latina também se pensava e se escrevia sobre a discricionalidade e a jurisdição do design exatamente no mesmo momento; uma das diferenças é que não se publicava da mesma maneira... no mesmo ritmo -não necessariamente no mesmo volume de produção- até porque nem mesmo era uma expectativa. Assim como a editora Gustavo Gili não estava próxima nem cultural nem geograficamente, a maioria dos designers da região estavam atolados com a criação de cursos universitários, debatendo a disciplina nas associações nacionais e brigando para a disciplina fizesse parte dos diferentes planos governamentais. Essas questões 
podem ter distraído os interesses editoriais latino-americanos -quem sabe-. De qualquer maneira, aqueles processos produziram textos enriquecidos de reflexões densas, que até esse hoje tinham passado desapercebidas na historiografia do design. Ideias e teses acerca da prática profissional vinham sendo escritas na região ao menos desde o pioneirismo de Clara Porset e Tomás Maldonado desde o final dos anos 1940. ${ }^{1}$

Parece-me que as linhas de pensamento e reflexão do design produzido na região poderiam se agrupar em dois grandes blocos até 1980 ou 1985. Blocos compreendidos como momentos e não como tendências de pensamento, ainda que uma coisa termine influenciando a outra. Por uma parte -como abordarei no percurso do argumento-, me parece notória a existência de um grande movimento que poderia caracterizar como um exercício estético-político. Nesse primeiro bloco as reflexões em torno do design estiveram em permanente diálogo com os baluartes da Modernidade. Essas ideias variavam desde a forma como a criação artística deveria estar presente na cotidianidade -como era evidência do que Lucena chama "contaminación artística" a partir dos enunciados de Maldonado (Lucena, 2015)- até as relações entre beleza e utilidade, dado o seu impacto na qualidade de vida. Tanto Maldonado quanto Porset, cada um em sua própria maneira de abordar e escrever, tratam aquele 'problema ilustrado' na relação com o design.

O segundo bloco -ainda não sei dizer em que grau de conexão, se ligado ou desligado do primeiro- foi marcado por uma clara relação do design com a tecnologia, se desenvolvendo desde os anos 1970 e claramente multiplicado a partir desse momento. Notoriamente envolvido nas concepções cepalinas -da CEPAL: Comissão Econômica para a América Latina e o Caribe- sobre a tecnologia, as suas relações com o desenvolvimento, a economia e -um pouco mais tarde-com o meio ambiente, a base do argumento era resultado de uma mistura de vívidos nacionalismos que em muitos momentos virava automaticamente regionalismo nas proporções da América Latina. Esse envolvimento dialogava com uma intrincada rede de ideias, que estavam ligadas às

\footnotetext{
${ }^{1}$ Com o objetivo de traçar um panorama general sobre a discussão industrial em contextos não industrializados, Gabriel Simon organizou uma coletânea de textos que recolhe de revistas cubanas, argentinas, chilenas, espanholas e mexicanas. Esses textos, debatendo os problemas jurisdicionais da profissão, contêm os sonhos, desafios e problemas relacionados com a ideia do design. Simon decidiu organizar cronologicamente a coletânea, a qual apresenta dois textos de Clara Porset, um de Tomás Maldonado em 1949, textos dos argentinos Francisco Bullrich e Norberto Chaves, dos mexicanos Horacio Durán, Jesús Virchez, Gabriel Simón e Oscar Salinas, do chileno Fernando Shultz e do cubano Iván Espin (também inclui alguns outros textos de designers estrangeiros). No final, ele afirma que "el lector se dará cuenta que lo que caracteriza al concepto de diseño es su pluralidad, su posibilidad de ser interpretado con arreglo a concepciones doctrinales contrapuestas" (Simón, 2013, p. 39).
} 
expectativas da criação para os outros -em claro vínculo com a Arquitetura Moderna Latino-americana, onde muitos dos atores se formaram-; às críticas especializadas acerca da economia, da industrialização, da urbanização, da técnica e os seus propósitos; às condições da realidade social da América Latina; aos postulados que no passo do tempo viraram Teologia da Libertação; aos princípios que determinaram tanto a Teoria do Centro e a Periferia, como a Teoria da Dependência -as duas no coração da CEPAL-; assim como aos elementos que dão base à Teoria da Libertação. Um cenário composto pelo diálogo e a crise com o cosmopolita e o local, aonde as reivindicações com as circunstâncias, com o essencial e com o anti-imperialista, participam da trama como dando uma ilusão de forma.

Posso dizer que esse enredo governou os raciocínios de uma grande parte dos intelectuais latino-americanos durante o século 20, sendo notório -especialmente para o meu argumento- aqueles arquitetos e designers, que configuraram a sua experiência durante as décadas meridionais do século.

Querendo fugir de chauvinismos inúteis, as misturas conseguidas por esses intelectuais na hora de introduzir as suas preocupações com o design naquele tecelagem, deixam entrever configurações tão originais como desconhecidas. Desde o fato de pretender o levantamento do popular como base ideológica e metodológica do ensino do design latino-americano, até as concepções das funções e aplicações da sua discricionalidade em uma "economia de planificação", como sucede na particularidade cubana. As reflexões desses intelectuais deixaram uma pegada que claramente adensa e diversifica o discurso do design, acrescentando-se ainda o fato de que o faz desde uma época na qual -simultaneamente- os grandes nomes do design internacional atravessavam o mundo dizendo o que era e como devia se praticar o design... desde o preciso momento em que os missionários traziam a verdade para os cantos do mundo caídos em desgraça.

Boa parte desse segundo bloco, acabou se expressando na configuração da ALADI Associação Latino-americana de Design-, ela mesmo sendo um dois maiores megafones que a história do design latino-americano já conheceu.

2.

Além, dos seus possíveis sucessos ou fracassos -o qual nunca governou o meu raciocínio ao me interessar por ela-, a ALADI foi fundamentalmente uma arena de 
debates sobre a discricionalidade e a jurisdição do design, entre os seus inicios em 19781980 e a primeira metade dos anos 1990. Um fórum que pretendia definir coletivamente para que é o design e o porquê de sua importância para a 'nossa cultura', não engolindo sem reflexão as outras ideias, mas sim, digerindo-as para vomitá-las transformadas em uma outra forma. Como diria Oswald de Andrade: fazendo antropofagia.

Diferentes sensibilidades faziam com que toda uma geração de intelectuais latinoamericanos sonhasse com projetos da proporção da ALADI. Diferentes processos políticos e culturais marcaram as décadas nas quais indivíduos de gerações apaixonadas se formaram como arquitetos e designers durante os anos 1960 e a primeira parte dos anos 1970. Dessa forma, um workshop organizado no México em 1978 pode se tornar o cenário propício para que alguns desses apaixonados se conhecessem, dialogassem, encontrassem coincidências tanto nas formas de ver a sociedade quanto nas relações com o que veem de fora, e pensar na configuração da ALADI. A partir daí iniciou-se um processo que levou dois anos e que deu origem à Associação em Bogotá em novembro de 1980.

As similitudes na forma de ver e criticar a realidade parecem ser compartilhadas na generalidade. Apesar de que a ideia de uma associação regional de designers transitava na cabeça de diferentes profissionais latino-americanos, as formas como ela era entendida e as razões pelas quais ela era pensada não eram homogêneas. Se pensarse como latino-americano era um lugar comum ao que se sentiam convocados diferentes tipos de indivíduos da região, os detalhes e especificidades desse sentimento são diversos no momento de conceber uma ideia como a ALADI.

Em reivindicações colombianas e argentinas, uma associação de caráter regional tinha sido proposta anteriormente ao início do processo da ALADI em 1978. Aquelas reivindicações foram propostas por coincidência no México -ainda também em diferentes momentos- para a conformação de uma associação latino-americana de designers. Os colombianos -Rodrigo Fernández- em 1972 em uma reunião que a Associação Norte-americana de Designers celebrou na Cidade do México (ACDSecretaria de organización, 1979); e os argentinos -José Rey- em 1974 quando Basílio Uribe debate com os colegas da CODIGRAM mexicana as virtudes que um projeto desse tipo teria para a região (Rey, 2009). Apesar dessa suposta antecedência, o espírito em cada caso era diferente do que termina governando a criação da ALADI. A grosso modo, enquanto a ALADI procurava ser autônoma para se autogovernar, as propostas 
anteriores consentiam a ideia de serem braços regionais de instituições maiores, como o ICSID.

\section{Aproximações à ALADI}

1.

0 interesse pela micro-história do design em países da América Latina apenas tinha começado o seu percurso. A narrativa construída registra casos particulares com alguma relação histórica com o cenário em que se produz o evento estudado: as vezes cursos de design; as vezes produtos ou projetos; outras poucas biografias sociais e pouquíssimas construções institucionais. Se esse percurso apenas começou -últimos dez ou quinze anos- os olhares sobre a América Latina nessas questões são praticamente inexistentes. Duas ou três tentativas pretendem apresentar a região como a somatória de casos. É claro desde a iniciativa: são casos de eventos ocorridos em países da região e é claro que dificilmente darão conta da América Latina como unidade.

Se tudo isso se pode caracterizar como apenas iniciado, menções sobre a ALADI não conseguem superar esse estatuto: o de serem menções. Lucila Fernández (2008; 2012) apresenta alguns elementos da associação em diálogo com acontecimentos institucionais em Cuba. A mesma coisa acontece com Marcos Braga (2011), que trabalhando a operação das associações de design brasileiro -na particularidade da APDINS-, registrou algumas das ligações que se deram no processo com ALADI (APDINS é a base brasileira que participa nela). De igual maneira Gladys Zuluaga menciona aspectos que podem dar um determinado 'decorado' ao cenário do design em Medellín, Colômbia, durante os anos 1990 (Zuluaga, 2015). É esperado que ao estar interessada em fazer uma genealogia institucional do design em Cuba -no caso de Fernández-, como no funcionamento da associação carioca de designers em Braga -carioca é o gentilício do que nasceu no Rio de Janeiro-, ou de relativa perspectiva para o objeto de estudo como acontece em Zuluaga, as ideias sobre a ALADI surjam como diálogo conjuntural e não como caso aprofundado de estudo.

2.

Acompanhando os textos anteriores existe um artigo publicado na Inglaterra que se aproxima muito mais da ALADI. O texto de Tania Messell (2016) apresenta uma problemática histórica interessante, na qual termina envolvida a criação da associação 
latino-americana, ou ao menos, uma das reuniões que lhe da forma. 0 cenário: o 11ํㅜ Congresso do ICSID que ocorreu na Cidade do México em 1979 -um ano após do workshop que marquei antes-. Messell mostra uma face da retórica da assistência -digo eu, no sentido em que Sennett (2012) problematiza a solidariedade- que se concretiza no interior do ICSID por esses anos. Essa face é a base de um relacionamento que o Council estabelece com os "países em desenvolvimento". A mim me parece que a aproximação de Messell é importante dado o fato de reconhecer tanto a verticalidade naquele olhar, quanto o valor que pode ter a produção latino-americana do design como uma 'epistemologia diferenciada' -termo meu-. Ela respeita determinado tipo de fontes primárias e tem uma relativa prudência para problematizar o assunto, assim como a sensibilidade em documentar um evento importante para a história institucional do design mundial.

Apesar desses valores, encontro duas reservas no texto: a primeira é a imprecisão histórica que comete -que termina sendo significativa-, ao lhe outorgar a esse congresso, o cenário a ideia de criar a ALADI. Segundo a narrativa de Messell, tanto a estrutura, quanto a dinâmica do congresso mobilizam a ideia de configurar a ALADI, dado o mal-estar que promove a aproximação assistencialista do ICSID com os latinoamericanos presentes. A defesa eurocêntrica das teses sobre o design em contraparte do 'corajoso discurso' de figuras latino-americanas como os mexicanos Horacio Durán e Jesús Virchez, são os pontos visíveis dessa tensão. Não discuto o valor desses discursos, como tampouco vários dos importantes detalhes dessa tensão ou da organização do evento, que apresenta Messell. A questão é que a reunião de latino-americanos para fundar ALADI naquele congresso, acaba sendo apenas um dos passos de um processo ainda um dos mais importantes como exporei à frente- ${ }^{2}$ iniciado anteriormente e não sendo o evento inicial. Os indivíduos inseridos no processo queriam aproveitar a plataforma do congresso para aumentar o número de adeptos no projeto, como manifestam Claudio Rodríguez -que sendo parte da organização do congresso queria organizar a situação para que acontecesse de forma controlada-, ou Rómulo Polo, que já

\footnotetext{
2 E que eu chamo de 'Pacto das catacumbas' em honor do acontecido em Roma em pleno coração do Concilio Vaticano II em 1965. Esse Pacto lá é um documento tipo manifesto, que organiza ideias já em processo em regiões como Latino América -a enorme maioria dos reunidos são latino-americanos-, e que dão chão à Teologia da Libertação a partir de 1969. Para mim o Pacto, representa um olhar diferenciado nos bispos assinantes, em relação com a ideologia dominante que governava desde o centro da instituição. Como no caso do documento produzido durante o Congresso do ICSID no México em 1979, o Pacto foi assinado na clandestinidade, nesse caso da Catacumba de Domitila em Roma.
} 
tinha participado das duas grandes reuniões que precederam a formação oficial da ALADI, assim como à que ele mesmo promoveu para que os colombianos preparassem um manifesto para levar no México em 1979.3

Para o incauto, essa imprecisão cronológica é explicável e não representa muito problema aclará-la. Para o paranoico, não parece tão simples. Explicar um fenômeno social como a formação da ALADI como um reflexo -que é o que jaz nesse argumento-, reduze os processos sociais aos maniqueísmos da influência: aceitação e rejeição... metrópole-periferia... civilização e barbárie. Como mostrarei, a criação da ALADI correspondia mais a chamados históricos complexos, de longas genealogias, e intrincadamente relacionados com aspectos da identidade latino-americana, que ao fato de se contestar o olhar ou os argumentos de organizações internacionais, que acabam por ser, na realidade, estopins. Se a possibilidade de se reunir com colegas da região se dava por causa de eventos organizados por instituições ' $x$ ' ou ' $y$ ', o lugar delas -as suas ideias, propostas e sentidos- finalmente passavam para um segundo plano, era conjuntural.

A segunda crítica que faria ao texto de Messell, é mais circunstancial. Gira em torno da exclusividade que ela outorga para certa pedagogia diferenciada do design na UAM mexicana -Universidade Autônoma Metropolitana-. A UAM poderia ser um exemplo quando se compara a instituição com outras experiências fora da região, mas não era extraordinária na América Latina. Quem observa as grades curriculares dos cursos de design criados na época seguramente perceberá que esse tipo de aposta -sintetizados por Messell no privilégio do antropométrico, o tecnológico e o social para um projeto de design- fazem parte do coração dos cursos na grande maioria de casos nos diversos países da região. De fato, esses cursos ao serem criados por arquitetos formados nos anos 1960 na região, poderiam ser quase uma tradução das experiências que tiveram em sua formação, e efetivamente melhorados a partir da crítica acumulada e aos anos de experiência no campo profissional do design. Experiência e crítica chegada para a

\footnotetext{
${ }^{3}$ A partir da conversa com Claudio, fico com a ideia de que eles -organizadores do congresso- queriam tanto estimular o processo já iniciado para a criação da ALADI, quanto fazer sentir confortáveis os convidados internacionais da região. Igualmente, as minhas conversas com Rómulo me deixam claro que esse foi um evento importante para a difusão da ideia, dada a presença dos mais diversos colegas da região, mas era um evento que se queria aproveitar para fortalecer o que já caminhava desde um ano antes. Assim como as memórias de vários atores lhe outorgam o inicio da ALADI nesse congresso -a ilusão de que as coisas começam quando as pessoas as conhecem-diferentes documentos permitem demostrar que o processo completava um ano naquele momento. Um desses é o Manifesto que preparam os colombianos, que é redigido em Bogotá junho de 1979 -três meses antes do congresso- na tentativa de apresentar a versão colombiana sobre a futura ALADI (Gutiérrez, et al., 1980).
} 
escrivaninha na hora de pensar esses cursos de 'design perfeitos' para as condições do contexto.

\section{Questões, fontes e procedimentos}

1.

A inquietude que mobilizou esse trabalho gravitou em torno da compreensão das condições sociais que permitiram a criação da ALADI, o seu funcionamento e a sua percebida mudança a partir de 1995.

A pesquisa iniciou em torno do palpite de que a associação tinha se conformado por causa de reivindicações políticas -que alguns classificariam dentro da chamada "antropologia econômica marxista" (Létourneau, 2007)-, com tais graus de convicção, que tanto ilusionava como dava força para o funcionamento da associação durante os anos 1980. No caminho compreendi que ainda essas reivindicações expliquem parte dos acontecimentos, eles são muito mais densos e heterogêneos.

Agora, no inicio também apostava na ideia de mudança pelo que podia perceber na generalidade. Já sabia que esses anos são determinantes para a historia social e cultural da América Latina, dados processos que desmancham e processos que iniciam. Contudo, só na pesquisa comecei a ligar as derivações, que -como para a fundação- são muitas e heterogêneas. Tanto uma quanto outra eram conjecturas iniciais que pretendi deixar nesse nível; que tal vez -e só isso- organizassem as primeiras perguntas que lhe faria às fontes. 0 propósito de proceder assim era simples: não queria lhe impor uma impronta predeterminada aos eventos, tentando que eles me mostrassem o caminho. Tentei que essas presunções ficassem em suspenso.

Dada a natureza da pesquisa, o arquivo foi formado por mim a partir de viagens realizadas para a coleta de fontes primárias, sendo essas fontes de dois tipos principais. O primeiro tipo -associado ao conceito tradicional de documento- são manuscritos que fazem parte da memória relacionada com a ALADI. Nesse grupo aparecem desde documentos oficiais da associação como correspondência, atas de assembleias, memórias de eventos, publicações, convites, artigos jornalísticos de cobertura de congressos e assembleias, passando por fotografias; até documentos mais pessoais dos diferentes membros, como anotações, cartas privadas, fotografias pessoais, peças colecionadas, rascunhos de manuscritos da época, ou inclusive desenhos durante as 
reuniões, como os que me mostraram com orgulho Jesús Gámez em Bogotá e Fernando Shultz na Cidade do México.

Nesse grupo também ficaram registrados documentos parcialmente relacionados com a ALADI, como folhetos de exposições feitas por organizações e/ou membros, artigos de jornais internacionais sobre o trabalho de cada um, cartazes, partes do portfolio de trabalho, etc. Talvez a maior quantidade de documentos desse subgrupo seja o volumoso material relacionado com o $11^{\text {o }}$ Congresso do ICSID, que foi realizado no México. Esses materiais foram generosamente cedidos por Oscar Salinas, Oscar Hagerman e Claudio Rodríguez na Cidade do México. Nesse grupo também está o relacionado com o chamado "Group 4" e os "Interdesign": pastas que consegui revisar no Design Archives da Universidade de Brighton na Inglaterra, onde graças à assistência de Lesley Whitworth tive uma fantástica experiência de trabalho de arquivo.

Estabeleci o trabalho com esses documentos a partir da minha necessidade em visualizar as séries que apresentavam. Séries tanto no sentido habitual -como aquilo que se repete indiscriminadamente nos documentos- como no sentido da aparição esporádica ou mais ou menos espontânea de eventos. Tentei dedicar a mesma atenção em uns e outros, pretendendo dar espaço à heterogeneidade. Organizei cronologicamente esses documentos, separando-os pela sua correspondência com eventos específicos -o congresso inaugural, os congressos dos anos 1980, entre outros-. Dessa forma vários desses eventos manifestaram a sua própria lógica, revelando a existência de séries internas que inclusive estavam fora das séries gerais que traçavam as fontes para o percurso total. Dessa forma se formou a estrutura de cada capítulo como exporei adiante. Os vazios documentais, assim como a maior parte das explicações e interpretações foram preenchidos pela minha abdução.

2.

O segundo subgrupo das fontes primarias foi formado pelas entrevistas com os atores envolvidos nos diversos processos da ALADI. Foram feitas 34 entrevistas, com 30 pessoas, completando quase 63 horas de gravação. Esses atores podem ser agrupados pelos diferentes momentos dentro da associação: alguns deles fazem parte das fases pré-fundação; outros são fundadores; outros parte da primeira geração da ALADI que percorre a década dos anos 1980; outros são parte de uma espécie de geração de transição que aparece desde a terceira ALADI; outros tantos foram assistentes do 
processo no seu país e outros, finalmente, membros atuais da associação. Esse agrupamento é ilustrativo. Os grupos não são mutuamente excludentes. Por exemplo, Paolo Bergomi é membro ativo hoje, mas aparece se relacionando com a ALADI desde 1984.4

As entrevistas foram pensadas com base nos trabalhos de antropologia de Clifford Geertz (1973), Nigel Barley (1989) e Pierre Bourdieu -desse último, sobretudo no seu trabalho "A miséria do mundo" (Bourdieu \& outros, 1997)-. Dessa forma, elas foram concebidas como 'conversas' semiestruturadas. Como pretendia traçar uma cartografia dos capitais sociais e culturais dos atores, para visualizar elementos das condições sociais de ideias nos raciocínios dos atores, a primeira parte da conversa sempre girou em torno das características dos núcleos familiares em que cada um deles cresceu. 0 desempenho e as qualidades intelectuais dos seus pais e familiares em geral foram discutidas nesse bloco, assim como os colégios aonde estudaram, o tipo de hobbies, anelos de adolescência, influências e/ou determinações para decidir estudar uma ou outra coisa na universidade. Também falamos usualmente das lembranças desse período, assim como das estruturas acadêmicas que encontraram naqueles cursos universitários: formatos de trabalho, filiações teóricas e metodológicas, etc. Esse último item, por exemplo, me deu a possibilidade de comparar expectativas e apostas da arquitetura latino-americana, e dos casos do design que já nesse momento se iniciavam.

A segunda parte das conversas usualmente tratavam o início das experiências profissionais, assim como as suas posturas políticas em respeito ao que acontecia em seus respectivos cenários, esclarecendo as diferentes razões pelas quais acabaram se envolvendo com o design, assim como a quantidade e qualidade de eventos de design relacionados com o campo profissional, os seus momentos, problemas e desafios, todos relacionados com a genealogia do que aconteceria com a ALADI.

Já a terceira parte das conversas abordaram as lembranças e detalhes em torno da participação de cada um no projeto da Associação. Dependendo do papel que cada um deles desempenhou, essa parte da conversa era mais ou menos densa; mais ou menos emocionante -tanto no positivo, quando no negativo, algumas vezes indiferente-; e mais

\footnotetext{
${ }^{4}$ Há ainda algumas entrevistas que considero importantes que, por restrições orçamentárias, não consegui marcar, entre outros: Pablo Robles no México; Denise Edelman, Elio Grossman e João Roberto do Nascimento no Brasil; Lourdes Marti nos Estados Unidos; Oscar Pamio na Costa Rica; Rodrigo Walker e José Korn no Chile; Guido Diaz no Equador e Nelly Toledo no Porto Rico.
} 
ou menos aprofundada. Essa era a base geral pretendida para cada uma dessas conversas. Porém, tanto a dinâmica da conversa quanto a preparação para cada depoimento, gerou deslocamentos diferenciados. No primeiro, óbvio, dado o ritmo, a natureza do diálogo e o clima da entrevista, no segundo, suspeitando a partir da análise da documentação que o futuro entrevistado poderia me explicar isso ou aquilo, eu incluí questões especiais na estrutura.

Em geral, essas conversas duraram 90 minutos, com notórias diferenças no caso de Luiz Blank, com o qual conversei por quase cinco horas, ou de Fernando Shultz, Jesús Gámez e Claudio Rodríguez com os quais conversei aproximadamente três horas. As entrevistas foram feitas em português e em espanhol, assim como filmadas e fotografadas, com a indispensável, inestimável e muito pertinente ajuda da Bibi, minha mulher, que é fotógrafa de profissão.

A estrutura dos blocos marcam a generalidade das séries para comparar as entrevistas. Contudo, o uso dessa estrutura girou permanentemente em torno do que marcava a documentação. Dessa forma, ainda que esses dois tipos de fontes sejam considerados como fontes primárias, defini usar as entrevistas como complemento do que os documentos escritos atestavam, decisão talvez explicada por uma razão e um capricho. 0 capricho -preconceito metodológico- tem relação com a ideia de que a produção feita no momento recolhe a grande maioria de sentidos do acontecimento no momento em que ocorre. Nessa perspectiva, a ideia de 'pureza' está mais relacionada com o que se escreveu no preciso instante e que ficou registrado como evidência do acontecido. Sendo assim -e nesse momento explico a razão- a memória é falha e pode distorcer ainda mais os fatos do que os documentos escritos. Já a imagem do acontecimento é mediada por vários elementos como a percepção biológica e social de cada ator no momento em que acontece um evento. No decorrer do tempo essas imagens vão desvanecendo, se misturando e até criando situações inexistentes. Sempre acreditei que lembrar acontecimentos de 30 ou 35 anos atrás traria problemas de registro nessa pesquisa, que se multiplicariam ao serem feitos sem elementos de triangulação.

Não quero dizer com isso que na pesquisa eu estivesse comprometido com uma ilusão de verdade única ou de fidelidade da narração dos acontecimentos. Esse positivismo é vazio, um "empirismo abstrato" como diria Mills (2003). A minha intenção foi colocar elementos de tensão que me permitissem determinar aqueles sentidos 
narrativos que virassem sintomáticos. É por isso que trechos das entrevistas usualmente são usados no argumento, na pretensão de adensar a descrição.

Contudo, ainda fosse essa a estratégia general, é importante reconhecer que em alguns momentos, determinados elementos que surgiram em alguma conversa, determinaram linhas narrativas que por vezes acabaram não sendo trianguladas pela falta de documentação ou fontes secundárias. Nesses casos, essas linhas são das mais livres do meu raciocínio. Se todo o argumento é provisional, essas abduções o são ainda mais.

3.

O diálogo permanente entre fontes se fez complexo com as fontes secundárias e a chamada "teoria substantiva". As primeiras ofereceram variadas anedotas, descrições e problematizações que permitiram adensar o que as fontes primárias apontavam. Todo o meu argumento dialoga com essas fontes. Porém alguns capítulos estão construídos fundamentalmente a partir delas, usando-as como fontes primárias. É o caso das partes nas quais pretendo marcar genealogias -capítulo 4- ou explicar as mudanças sociais da região durante os anos 1980 -capítulo 6-. Nesses casos, a diferentíssima quantidade e qualidade de literatura sobre a América Latina, os seus processos sociais, culturais e econômicos, me acompanharam durante esses anos de trabalho. Nos outros capítulos, uma diversa gama de textos sobre histórias particulares do design -para demonstrar um exemplo- me permitiram colocar em perspectiva algumas das fontes primárias.

Devo dizer que as coletâneas sobre história social da América Latina foram o grande insumo dentre as fontes secundárias. Sem descreditar as outras fontes -várias delas muito boas-, as compilações sobre processos políticos, econômicos e sociais da região como a de Evelina Dagnino et al. (2010), José Luis Reyna (1995), Marco Palacios \& Gregorio Weinberg. (2008) e Leslie Bethell (2011) foram fundamentais para compreender a densidade das problemáticas latino-americanas após 1930. Delas, as três últimas sendo abordagens que pretendem problematizações temáticas da região como unidade.

Além disso, os textos especializados em pequenos problemas também alimentaram esse diálogo e a minha interpretação. Casos de análise da crítica literária, das artes visuais, da arquitetura moderna e do design estão presentes durante todo o argumento. 
Por sua parte, a chamada "teoria substantiva" não esteve ligada de forma predeterminada. Intuí pela natureza da minha pergunta nesta pesquisa, que a construção do argumento gravitaria em torno da sociologia das profissões, porém, não restringi a análise às suas categorias críticas. Pretendendo um relativo ascetismo, e como já mencionei, não quis lhe impor categorias às fontes primarias, deixando que elas me mostrassem lugares nos quais devia aprofundar e complexificar o olhar. Dessa forma, à uma linha relativamente robusta de teóricos das profissões, conhecidas por mim a partir de pesquisas anteriores, foi somando algumas categorias relacionadas com a circulação de ideias -como a teoria das comunidades interpretativas-, o nacionalismo e algo -muito pouco em verdade- das teses do pós colonialismo.

4.

Agora, quando digo que pretendia não impor categorias, não quero dizer que os fatos se classificavam sozinhos, como seguindo mecanicamente a sua própria ordem. Pretendi permanentemente uma operação que me pareceu complicada, e que recolhe as clássicas sugestões de Marc Bloch (2002) em torno do questionamento das fontes. Para ele, era claro que as fontes deviam ser interrogadas para que fossem historiograficamente úteis. Essas perguntas são no final das contas uma mirada colocada na minha percepção no momento de aceder ao acervo.

A operação que pretendi na pesquisa acolheu a sugestão de Bloch, complementada pelos procedimentos de Ginzburg. Para o italiano -Ginzburg- deve existir um permanente diálogo entre os que ele chama de elementos etic e os elementos emic, a partir da linguística de Pike. Sem detalhar aqui, a ideia é a de perturbar e subverter permanentemente o processo de pesquisa, deixando que a natureza de dados e pistas não só se expressem, mas levem o pesquisador a novos e inesperados lugares

[...] Na pesquisa, como no xadrez, as aberturas são importantes, às vezes decisivas; em todo caso, influenciam longamente o curso do jogo. A responsabilidade de quem faz pesquisa começa aqui (Ginzburg, 2005, p. 167).

Ginzburg sabe que as perguntas que se fazem aos documentos -aquelas que defende Bloch- dão limites a pesquisa. Por tanto, o fato de subverter o processo com o objetivo de visualizar perspectivas não previamente consideradas, é um valor essencial tanto para a compreensão das ligações e trilhas, quanto uma complicação como 
mecanismo intelectual. Valor na medida em que mostra elementos que adensam explicações; complicação quando exige um processo de descentralização permanente do pesquisador que é difícil de realizar. Um se afastar de si mesmo, quem sabe, se no sentido que defendia Bourdieu no momento da objetificação do sujeito objetivante

[...] El sociólogo es un tipo que fastidia porque se la pasa quitando los estrados, los taburetes, los zancos, los coturnos que usted tiene bajo los pies, y a veces hasta el suelo que pisa. Es lo que hace que la sociologia parezca triste, pero no es la sociologia la que es triste, es el mundo (Bourdieu, 2010, p. 36).

Ao final, pretendi construir uma narrativa a partir do diálogo e a crise que se estabeleceram nos meus raciocínios na análise das fontes primarias e dos caminhos inesperados que de vez em quando me parecia necessário transitar, as fontes secundárias e o cenário, tudo mediado tão organicamente quanto possível, pelas categorias que a teoria configurava no meu olhar. Persegui permanentemente -e em meio da pertinência- esses procedimentos. Em minha cabeça esteve tudo tempo presente aquela máxima, que me parece claramente expressada por Roger Chartier

[...] El conocimiento histórico se inscribe así en un paradigma del conocimiento que no es el de las leyes pertenecientes a la matemática ni tampoco el de los únicos relatos verosímiles [...] La intriga debe entenderse como una operación de conocimiento que no pertenece al orden de la retórica sino que plantea como central la posible inteligibilidad del fenómeno histórico, en su realidad borrada, a partir del cruce de sus huellas accesibles (Chartier, 2005, p. 75).

\section{A minha infraestrutura}

1.

Para tentar uma compreensão do tecido que explica os processos da ALADI, dividi o argumento em três grandes partes. Partindo do pressuposto de que o Design é um produto social produzido por adensamentos sociais -a metáfora do raio em céu descoberto de Marx (2003) sempre é ilustrativa-, a primeira parte -composta pelo primeiro capítulo- pretende ilustrar a cartografia institucional que explica a existência do design na América Latina. Ainda que eventos costarriquenses e guatemaltecos possam aparecer, construí o argumento com base nos fatos acerca daqueles países que foram determinantes na configuração da ALADI entre 1978 e 1995: Argentina, Brasil, Colômbia, Cuba e México. Esses casos são efetivamente os principais focos de informação, porém nesse capítulo o argumento pretende um olhar horizontal da região e 
não de análise parcelada, pretendendo fugir da ilusão de que a somatória representaria o total.

0 grosso de informações desse argumento são as próprias menções que as delegações fundacionais da ALADI expuseram em 1980, no marco da criação da associação. Como tratarei no capítulo 3, nesse evento realizado em Bogotá, os organizadores colombianos parecem ter convocado as delegações da região para expor detalhes dos processos de institucionalização do design nas suas respectivas sociedades. $\mathrm{Na}$ documentação que encontrei, esses cinco países, foram os que entregaram documentos 'mais detalhados' em esse tipo de eventos.

Contudo, sendo essa a base das linhas analíticas do capítulo, trechos de algumas entrevistas, assim como triangulações provenientes de fontes secundárias, completam um argumento que, me parece, explica os antecedentes das relações com o design nos países da região que terminam envolvidas na ALADI.

2.

A segunda parte do texto está configurado pelos capítulos 2 , 3 e 4 , que compreendem o processo de fundação da ALADI. Uma reconstrução do processo da sua configuração, apoiado na cor e no matiz das discussões e discursos que lhe dão forma; as apostas conceituais sobre o curso -o que é em si, a base de uma voz latino-americana do design da época-, assim como os vínculos que essas ideias tem com determinados sistemas de difusão -“caixas de ressonância” como seguramente diria Serge Gruzinski (2012)-, no qual o latino-americanismo é tanto a base, como o eixo em torno do qual se configuram os postulados.

Como cada capítulo dessa parte pretende dar conta de uma questão particular, cada um manifesta determinadas diferenças a respeito de fontes e procedimentos. Por exemplo, a maior parte do capítulo 2 aborda a reconstrução da primeira reunião do processo no México em 1978. Por isso o construí fundamentalmente acima dos acervos pessoais de Luiz Blank no Rio de Janeiro e de Rómulo Polo em Bogotá, assim como dos seus depoimentos. Eles foram dois dos oito latino-americanos que se conheceram lá e que logo de debater e pensar na ideia de uma associação dessa proporção, decidiram assinar o primeiro documento -um manifesto- que orientava o processo de configuração até 1980. Não consegui entrevistar os outros seis: vários deles já morreram e outros parecem ter perdido ligação com o campo. Em todo caso, como é 
notório na documentação, Blank, Polo, Robles e Rivera (os últimos mexicanos) são os mais fortes promotores da ideia.

No mesmo capítulo, as menções sobre as reuniões intermediárias entre 1978 e 1980 se complementam tanto com o acervo pessoal, quanto dos depoimentos da grande parte dos entrevistados na pesquisa: as volumosas contribuições dos acervos de Jesús Gámez em Bogotá, Oscar Hagerman, Oscar Salinas e Claudio Rodríguez na Cidade do México assim como os documentos de Interdesign e Group 4 que consegui revisar no Design Arquives da Universidade de Brighton.

Em todo o capítulo, o trabalho de séries foi estabelecido segundo elas surgiam da documentação. Nesse processo configurei as linhas visíveis e persegui as pegadas que considerei pertinentes, e que apareceram quando pretendi subverter o sentido da busca. Em tais casos procurei fontes secundárias que me ajudaram a fazer complexa a interpretação, sendo, talvez, a parte mais notória desse exercício o último subtítulo do capítulo: "O assedio dos intrusos".

No capítulo 3 trabalhei de uma forma mais ortodoxa. Como nessa parte eu pretendia a visualização de acordos da estrutura da associação -explicados como continuidades- e a explicação das linhas do discurso da ALADI -o que significava e para que servia o design na região-, foquei nas memórias do primeiro congresso da Associação, ocorrido em 1980. Devo dizer que esse acervo está localizado na Biblioteca da Universidade Nacional em Medellín, na Colômbia, ao que tive acesso pela sensibilidade e generosidade do meu grande amigo Augusto Solórzano, quem sem saber o que era -a ficha catalográfica não explica- o cedeu para mim em 2010. No percurso da pesquisa descobri que Jesús Gámez em Bogotá tem uma outra cópia desse material, sendo as únicas duas cópias que eu conheço.

A memória é, em síntese, os documentos manuscritos que cada delegação entregou no evento inaugural da associação em 1980. Esses textos são manifestos que defendem posturas concretas sobre a jurisdição e a discricionalidade do design na América Latina, sendo em seu 95\% textos inéditos. Com eles nas mãos tracei as séries que manifestavam, de onde consegui determinar quatro grandes grupos para a tese. A sua repetição, compartilhamento e frequência, demostraram para mim a existência de vasos comunicantes concretos, que fazem com que latino-americanos nascidos nos diferentíssimos cantos da região vejam no design praticamente as mesmas promessas e virtudes. Algumas pistas dentro desses documentos me levaram para o PNUD 
(Programa das Nações Unidas para o Desenvolvimento) e de aí cheguei rápido na CEPAL, aonde já tinha suspeitas que chegaria, após as menções do PNUMA (Programa das Nações Unidas para o Meio Ambiente), quando apareceu com tanta força na documentação relacionada com o Interdesign de 1978, aonde tudo iniciou.

Percebendo aquele tributo com aqueles vasos comunicantes, escrevi o capítulo 4. Nele sigo o fio de elementos que me sugerem procurar os caminhos pelos quais transitam ideias na América Latina, para uma forte linha de intelectuais, literatos, artistas visuais, arquitetos e designers da região na segunda pós-guerra. 0 meu trabalho nessa parte do argumento foi o de seguir as ideias defendidas pelos fundadores da ALADI, no discurso da Arquitetura Moderna -berço profissional de onde provêm a enorme maioria deles-; a crítica sobre a tecnologia circunstancial -como a que configurava a CEPAL desde os anos 1950-; a crítica econômica de onde se deslocava esse olhar da tecnologia; passando pelos princípios da Teologia da Libertação que fundamentalmente organiza uma teologia do Outro, aonde o povo, o camponês e o popular em geral são o centro das preocupações; para chegar em uma nítida defesa do latino-americano desde a criação mesma dele como Comunidade Imaginada -no sentido de Anderson (1993)- em meados do século 19. Para mim -como pretendo demonstrar nesse capítulo- tudo isso em complexa relação com configuração de ideias e sonhos que circulam pela região toda, organizando sentidos comuns e propondo linhas de ação com as que os jovens intelectuais se ilusionassem ao pensar, criticar e sonhar o mundo. Nesse momento do argumento, dialoguei com as categorias oferecidas pelas fontes secundárias provindas da história da arquitetura moderna, a história econômica e política da região, a história das ideias assim como a história da arte latino-americana.

3.

A terceira parte do argumento reúne dois capítulos. Como bloco, essa parte pretende ver como transcorreu a vida da ALADI durante os anos 1980 e a primeira metade de 1990. A estrutura do bloco é simples. O capítulo 5, mergulha no comportamento da Associação focado em dois grandes eixos. Por uma parte 'a vida' das assembleias e por outra o comportamento dos congressos durante esse período. Nos dois casos, me baseei fundamentalmente nas memórias dos eventos da ALADI desde 1982 até 1995. Com maiores ou menores detalhes, cada um desses documentos organiza as discussões e conclusões da respectiva assembleia, assim como apresenta o programa 
do congresso e até apresenta os anexos de acontecimentos. Todos eles se encontram na biblioteca do Instituto Superior de Diseño em Havana, Cuba, aonde acedi pela gentileza de Sergio Peña, o diretor do Instituto. Algumas versões complementares foram cedidas a mim por Santiago Pujol em Cuba, Oscar Salinas no México e Jesús Gámez na Colômbia.

Como no caso de Bogotá 1980, o olhar transversal dessas memórias, me permitiu a identificação de séries que viraram -por exemplo- linhas temáticas das palestras ou das apresentações feitas em cada congresso. Essa transversalidade das séries, me permitiu ter uma ideia de trajeto de onde, por exemplo, provem os gráficos desse capítulo. As vezes revisando o resumo, outras fazendo leitura transversal das palestras de cada congresso -quando disponível uma ou outra coisa- foi possível estabelecer uma área temática à que correspondesse. Isso gerou uma contabilidade mais ou menos confiável que um software como excel torna gráfico de forma relativamente simples. Como digo no respectivo momento, fora de pretensões estadísticas, os gráficos apresentados são material didático que exibem as trajetórias -temáticas nesse caso- no decorrer do tempo. As informações foram trianguladas com trechos de entrevistas e artigos jornalísticos que cobriram os eventos, naquele momento.

0 argumento do capítulo 5 demostra a percebida mudança da ALADI durante esse período, explicando algumas das razões internas para isso. Já o capítulo 6 pretende fazer uma reconstrução histórica do que representou econômica, social e politicamente o lapso entre 1982 e 1995 para a América Latina.

Como a explicação não é fixa, foi necessário acessar o passado da região assim como analisar algumas das características gerais do capitalismo pós-moderno. Para o último foi utilíssima a problematização de David Harvey (2014; 2014a; 2016), como os trabalhos de Richard Sennett (2009; 2012; 2014), assim como a introdução que isso apresenta para a região nos textos de Nicolau Sevcenko (2005), Nestor García-Canclini (2015) e finalmente Milton Santos (2013); para chegar às complexidades da região graças às analises densas de Joaquin Brunner (1995), José Luis Reyna (1995), Marcelo Cavarozzi (1995), Francisco Weffort (1995), Gonzalo Delamaza e Carlos Oschsenius (2010), Nora Lustig (1995), José Puello-Socarrás (2015), Luis Alberto Restrepo (2006) e Alain Touraine $(1987 ; 1989)$. 
4.

No final, parece-me que consegui explicar as condições sociais que fazem com que o modelo inicial da ALADI fosse concebido, assim como desmanchado. Quem sabe, esse desmanche chegue até ao ponto de dizer que a Associação desapareceu. A verdade é que ela seguiu operando, mas, efetivamente, já não com a narrativa nem com as pretensões ou promessas com que tinha nos anos 1980.

É importante ressaltar que, assim como posso afirmar que a ALADI pode representar o que a América Latina define sobre a jurisdição e a discricionalidade do design na região, também é necessário dizer que essa definição não foi homogênea nem compartilhada plenamente pelos membros da Associação e os diferentes participantes dela. Se a narrativa latino-americanista libertária governou os sentidos da sua fundação, é claro que a ideia de ser um órgão difusor e promotor que apoiasse as iniciativas empresariais também estava na mesa em Bogotá em 1980.

Nas duas perspectivas -e as outras que aprofundo no texto- dialogavam desejos com sonhos; experiências com justificativas; visões do mundo com perspectivas de trabalho... dialogavam categorias de percepção e capitais sociais -como chamaria Bourdieu uma e outra coisa-. E dialogavam no intuito da conformação de uma experiência. Precisamente aí, na pluralidade dessa experiência, é que podem aparecer as grandes diferenças, por exemplo, entre os designers de eletrodomésticos argentinos e os funcionários cubanos da ONDI -Oficina Nacional de Diseño-.

As diferenças e a experiência com a ALADI é diferente desde o inicio. Vários se emocionam com as lembranças dos processos e dos colegas quase quarenta anos após esses eventos. Outros nem tanto. A mim me parece que uma anedota é significativa: percorrendo os corredores da Universidade de Buenos Aires com Véronica Devalle, Paulo Ledesma e Bibiana Peña, encontramos com Ricardo Blanco -argentino e membro fundador da ALADI- entrando na sua sala. A entrevista com ele tinha sido realizada vários dias antes. Ao cumprimentá-lo, Blanco tomou a minha mão e irreverente desenhou um pequeno riso dizendo mais ou menos a seguinte ironia: "olvidáte de ALADI. Dedicáte a algo más importante." 


\section{Parte 1.}

As nuvens se conformam e no céu se dão as condições para que aconteça um raio... 


\section{0 design nesta periferia}

[...] Los países subdesarrollados se ven ante la única alternativa de desarrollar el diseño o ser dominados, colonizados a través del diseño extranjero, colonialista. 0 los países subdesarrollados diseñan, u otros diseñarán por ellos y en contra de sus intereses (Espín, 1980, p. 5).

O processo de profissionalização do design na América Latina pode ser datado a partir de diferentes enfoques, os quais, em sua grande maioria, parecem cair em duas armadilhas, sendo ao mesmo tempo inocentes e deformantes da realidade. Em uma dessas armadilhas estão inseridos aqueles enfoques -relativamente mais cientes- que explicam o processo regional de profissionalização como reflexo do pioneirismo estrangeiro na região, privilegiando de forma curiosa acontecimentos na Europa, na frente dos Estados Unidos, no que, igualmente existe uma filiação que só a ideologia poderia explicar. A outra armadilha -aparentemente mais sutil- aprisiona um enfoque embasado no chamado 'mito de origem'. Nesse, é privilegiado o ímpeto por 'demostrar' um ranking de antecedência histórico, ou seja, aqueles que iniciaram primeiro determinado processo -geralmente girando em torno da primeira escola-.

Me parece que essas armadilhas capturam essas interpretações pela necessidade por compreender o processo, a partir de linhas retas inquebrantáveis. Linhas que mais do que qualquer coisa parecem interessadas em demostrar a uni-direcionalidade do reflexo do pensamento estrangeiro e/ou em apoiar-se na ideia da conquista do primeiro lugar frente a um juiz imaginário. Seguramente alguma categoria psicanalítica explique tanto o delírio do primeiro quanto a ansiedade do segundo.

Em geral essas linhas retas pretendem marcar 'o início' do processo, assim como princípio e fim. Na intoxicação que produz o 'mito de origem', os eventos são arrancados das circunstâncias nas quais foram produzidos. Como diria Marx (2003): como se um raio acontecesse em céu descoberto.

No mínimo, esses procedimentos acabam por resultar em etnocentrismo e/ou anacronismo. Etnocentrismo porque se lhe trasladam expectativas culturais a diferentes sistemas sociais, como se todos os seres humanos pensassem e desejassem as mesmas 
coisas, sem importar genealogias e acordos intrínsecos de cada sociedade. Como se não existissem diferenças culturais. Anacronismo pela imposição de noções atemporais como da sociedade em que vive o pesquisador- relativas a um momento histórico que simplesmente não as considerava. Uma e outra claramente asfixiam os fatos, elegendo a repetição de narrativas que acabam por virar lugar comum, elegendo a repetição religiosa dos credos. Me parece que Gruzinski expressa nitidamente a complexidade de tal problema

[...] Fundamentadas ou não, todas essas explicações nos parecem redutoras; por pretendermos, a qualquer custo, absolver ou condenar o passado, corremos o perigo de perder o que faz sua singularidade e talvez, ainda, seu valor para nós (Gruzinski, 2012, p. 36).

Esse primeiro capítulo pretende enfocar algumas linhas que parecem atravessar o processo de profissionalização do design na região. Um enfoque geral que pretende esboçar uma fotografia da região como conjunto de eventos entrelaçados e não como a compreensão da união pela somatória das partes. Essa última estratégia é usada nas poucas coletâneas que pretendem a compreensão do design latino-americano como, por exemplo, as de Fernández \& Bonsiepe (2008) e a de Mondragón \& Mejía (2015), assim como as compilações sobre política, sociedade e economia da região.

Dessa maneira, detalhes que seriam usualmente esperados em relatos históricos, simplesmente não apareceram. Em vez disso, pretendo apresentar determinados eixos descritivos que correspondem a categorias que construo desde algumas reflexões da teoria das profissões e que coloco em diálogo com ações-chave vinculadas aos congressos da ALADI. Por exemplo, os documentos entregues pelas delegações dos países fundadores no evento realizado em Bogotá e Santandercito em novembro de 1980. Esses documentos de 1980, como aprofundarei em um capítulo posterior, mencionam vários momentos-chave para a compreensão do processo de profissionalização do design em cada país, sendo os casos do México, Cuba, Colômbia, Brasil e Argentina os mais notáveis. Além disso, incluo informações relevantes que surgiram nas minhas conversas com os atores da ALADI com que dialoguei. Algumas menções sobre fontes secundárias apareceram como contraponto, ou mesmo, definição do cenário relacionados a esses momentos-chave. 
Porém, o leitor não encontrará aqui uma história densa baseada nos estudos publicados acerca de cada país, assim como também não encontrará a revisão crítica dessa produção. 


\section{Entradas na modernidade}

[...] Los objetos de uso corriente van adquiriendo una nueva dimensión [...] Vuelve a hacerse posible el viejo hábito griego de convivir con formas bellas a la vez que útiles [...] Esto, porque el arte ha entrado a la industria. Clara Porset, julho de 1949 (Simón, 2013, p. 46).

\section{Uma revolução de irreverentes}

1.

Poderia se pensar que a profissionalização do design é um indicador de modernidade. Digo isso não só pelo fato de que o processo de profissionalização poderia, não só, ser compreendido como um processo de secularização e autonomia, mas também como um processo de especialização -o chamado "processo civilizatório"-, demonstrado pela consolidação de uma disciplina autônoma e complexa para a configuração de objetos e sistemas visuais para a vida cotidiana. A quebra de relações com a Idade Media e o seus significantes de 'selvageria', garantem a entrada na almejada 'era de luz e contínua realização' à qual se auto-atribui o Projeto Moderno -deliberada e arrogantemente escrito com maiúsculas-.

Da feitura de objetos para resolver as necessidades imediatas em relação com o contexto, a nossa espécie passou lentamente a se especializar técnica e socialmente. A satisfação das nossas necessidades -base da relação com a natureza para determinada linha de raciocínios- fez dos homens prolixos transformadores de matéria, se convertendo gradativamente em dedicados mestres e artistas. A outrora unidade indissociável existente entre a satisfação de necessidades vitais e a gradual contemplação e configuração do gosto -e até do prestigio-, foi tomando conta da vida social, enquanto dava apoio para o estabelecimento do homem em territórios hostis.

A satisfação de necessidades vitais então direciona o afastamento gradual do, contemporaneamente chamado, 'o artístico' e 'o cientifico', se especializando e institucionalizando com o passar do tempo (Buitrago \& Palacios, 2015).

O outrora chamado naturfacto, como é defendido por Edgar Martínez (Buitrago, 2006), objeto obtido diretamente da transformação da natureza, poderia se caracterizar 
como o tipo de objeto produzido pela espécie durante uma fase realmente longa. Uma fase delimitada pelos grandes ciclos que propõem, entre outros, Alvin Toffler (1993), e que vai até a Revolução Industrial de 1750. Em determinado sentido -e com os grandes problemas que supõe um traço dessa dimensão- é mais ou menos útil pensar que até esse momento, as produções humanas -que foram amadurecendo em complexidade material e técnica- respondiam à lógica de serem transformações da natureza, dentro da expetativa da produção de baixa quantidade -praticamente uma peça-. Apesar da especialização com o passar do tempo, essas peças eram produzidas de forma relativamente geral já que, nesse cenário, não há reivindicação a cerca da produção de determinado tipo de objeto, pelo menos até o momento em que os ofícios se tornam sistemas de classe.

Além dos detalhes que são infinitos nesse recorte, a conquista do movimento autônomo traz uma ansiosa e acelerada especialização, dados os desafios que supõem as mudanças da sociedade desde 1750. Da produção de séries pequenas -quando não únicas-, a produção de objetos passou a ser mecanizada. A especialização dos mestres, por exemplo, que tinham experiência técnica e até emocional com os materiais com os quais trabalhavam, foi substituída pela sua posição dentro da linha de produção. A partir da introdução da mecanização da produção, se tornou necessário o treinamento nas chamadas "artes industriais", uma formação voltada às habilidades com desenho e prévisualização necessárias nas indústrias modernas. Segundo velhos enunciados, como Danielle Quarante (1990), esse movimento explica a existência de escolas como a de Artes y Oficios de Barcelona desde finais do século 18, como antecedentes dos cursos de design moderno no século 20.

Na América Latina, várias dessas escolas se multiplicaram a partir de meados do século 19 com propósitos parecidos e, até mesmo, com vínculos institucionais ainda mais robustos dos que as europeias. Por exemplo, a Escuela de Artes i Oficios, criada em Bogotá em 1867, e vinculada à Universidad Nacional de Colombia alguns anos depois (Restrepo, E. et al., 2004, p. 9). Com objetivo de treinar os artífices da região acerca das complexidades oferecidas pela vida liberal, esses cursos procuravam abarcar desde o treinamento para a produção em série até a conquista de mercados internacionais, no que pareciam antecipar 100 anos das diferentes missões relacionadas com o design -ao qual retornarei mais a frente-. As diferentes conjunturas do século 19 e o vaivém do século 20 explicam tanto o relativo sucesso como o fracasso dessas ideias. 
Em determinado sentido, a especialização daqueles ofícios acompanhava o crescimento da complexidade da sociedade. Foi passar da transformação não especializada da natureza para a produção de naturfactos -quase sempre ferramentas- à gradual complexificação e dedicação especializada dos nascentes ofícios, para chegar na determinação de campos de domínio técnico e conceitual, obtidos pela reivindicação da sua autonomia e a luta por sua legitimidade social. Claro, o meu passo aqui foi mais do que geral. Uma imensa quantidade e qualidade de detalhes matizam e negam o que proponho. Contudo, meu propósito nesse momento é assinalar as caraterísticas que permitem pensar no design como inserido em um processo de modernização mais amplo. Quando determinada sociedade acredita na necessidade da existência de um profissional focado na produção de seus satisfactores, se está observando uma sociedade altamente especializada e decididamente segmentada. Ai, a existência do design como profissão é um sintoma.

2.

Os ritmos são diferentes e vão alcançando distintas metas dependendo da sociedade observada. Contudo -e em geral- as diferentes conquistas e desafios trazidas pelas revoluções do século 18, poderiam ser sintetizadas pelos pilares fundamentais das sociedades modernas: a industrialização e a urbanização. Tanto uma quanto a outra desenham novas dimensões para a vida e, claramente, determinam as particularidades da vida social latino-americana durante o século 20.

Dentro das grandes promessas, o chamado Projeto Moderno quebrava com a estrutura da aristocracia, a verticalidade no exercício do poder, os vínculos entre o poder civil e o poder religioso, a explicação esotérica da realidade, etc. Dissolvia as relações entre a acumulação de terra e o exercício naturalizado do poder, assim como sugeria uma nova legitimidade social embasada no raciocínio e não no carisma, ou muito menos na tradição que era evidentemente a sucessão por linhagem. Tudo isso e muitos outros assuntos, prometiam a chegada no futuro. 0 batalhado triunfo do homem. A cidade de muros brancos de Adolf Loos na Europa dos anos 1920. Para vários, a produção em série provocava a ilusão da conquista do ócio, enquanto a criação se relacionava com a originalidade e a busca do porvir.

Contudo, as hasteadas promessas não conseguiam cobrir as perversões que também produzia o processo. Me parece que na linha que expus no primeiro ponto, 
Marx o ilustra com clareza, quem sabe se abrindo uma linha de preocupações profundas no momento em que as artes industriais tentam compreender como é que funcionam nas urgências de mudança que o mundo ocidental apresentava. Quando ilustra as complexidades da máquina e a sua inserção na grande indústria, Marx ressalta como o princípio da evolução das espécies permite a sua sobrevivência na natureza (Marx, 1972). Se a qualidade de uma espécie é definida pelo seu sistema de aderência, o processo evolutivo vai desenvolvê-lo com o propósito de evitar a extinção. No caso do homem, isso aparece na sua habilidade de raciocínio e de criar um mundo artificial que dá suporte à vida. Dessa forma, a máquina como a maior evidencia do seu tempo (Buitrago, 2006).

Assombrosa pela sua engenheira, a máquina foi aplaudida como significante do progresso. Marx também a aplaude, mas a compreende como uma parte de um sistema maior ao qual é necessária e pelo qual é exigida. Não convém aprofundar aqui, mas é importante dizer que Marx assinalou um grande paradoxo no fato de ser ela o significante de todos aqueles princípios da modernidade, dado que ela converteu o homem em parte do seu funcionamento e não o contrário. Como dizia, o outrora artífice tinha experiência com os materiais, as ferramentas, os processos e os sentidos com os quais se reconhecia socialmente (Sennett, 2009). Com o aparecimento da máquina, ele foi alinhado na produção em tarefas especificas submetidas ao movimento mecânico para a produção de mercadorias. Dessa maneira, o homem é convertido em apêndice da maquina (Marx, 1972). Claramente, não é a máquina, mas a disposição do sistema em torno dela que engendra tal fenômeno. Nesse esquema, o capital é o eixo de exploração da força de trabalho e centro das reflexões políticas desde -pelo menos- o século 19.

As condições que libertariam o homem da exploração feudal, se reproduziram novamente com algumas diferenças. Se a promessa era uma grande ilusão, aquela reprodução era um desencanto. Quando Marx e Engels decidem escrever o Manifesto Comunista em 1848, a suas analises da Revolução Industrial de 1750 e os seus efeitos no percurso dos anos fizeram com que a sua conclusão terminasse no chamado à revolução para reorientar o caminho (Marx \& Engels, 2002). Para alcançar as virtudes do Projeto Moderno, era necessário mudar o mundo. 
3.

Não digo que automaticamente, mas no passar das décadas, diante dos desafios que as próprias circunstâncias latino-americanas traziam aos seus respectivos projetos de fundação para as repúblicas nacionais, esses impulsos em direção à mudança do mundo vão estimular uma linha de intelectuais da região. Não que isso tenha acontecido por conta 'da chegada' do marxismo. Assim como a grande maioria de assuntos latinoamericanos, parece prudente dizer que o diálogo com -nesse caso o marxismorespondia a parte das reivindicações regionais relacionadas com a miséria, a pobreza, a cilada dos Estados Unidos sobre os territórios, o estabelecimento das elites latifundiárias como elites do poder e a impossibilidade por superar os flagelos que a região trazia desde antes dos seus dolorosos processos de libertação -principalmente as ex-colônias espanholas-. Esses e outros assuntos dialogavam com a ideia de mudança do mundo, alentando e ordenando narrativas e sentidos retóricos, como defende Hobsbawm (2011).

Dessa forma, várias reivindicações foram se apresentando no cenário das novas repúblicas da região. Em distintos matizes, a Revolução mexicana iniciada em 1910 e os protestos estudantis que terminaram em reformas universitárias em Córdoba, Argentina em 1918 e que se expandiram pela região, mostram a necessidade das jovens repúblicas em compreender um momento histórico particular. Da mesma forma, eram -segundo Brunner (1995), García-Canclini (2015) e outros- ações que pretendiam deixar para trás o pesado tradicionalismo trazido do século 19.

As diversas circunstâncias provocadas pelo desenvolvimento das décadas de 1920 e 1930, colocam na mesa a crítica moderna na literatura e nas artes visuais para se pensar e se representar a realidade latino-americana, assim como os novos olhares sobre o papel da região no cenário mundial. Grandes escritores, artistas visuais e intelectuais de todo tipo, retornam das suas travessias pela 'Europa ilustrada' e se confrontam com a necessidade de se relacionar com a sua realidade. Obras que iniciam o caminho para o reconhecimento mundial, manifestos e até concepções e teorias foram desenvolvidas na região, no intuito de 'ser moderno' no território, como poderia se compreender das ideias de García-Canclini (2015). Em um capítulo posterior aprofundarei alguns detalhes dessa questão.

Por enquanto adianto que, nesse debate, as já mencionadas características da miséria e da pobreza passaram a ser vistas sob novo enfoque. Um exemplo seria o mural 
elaborado por Diego Rivera no Teatro Insurgentes na Cidade do México, no começo dos anos 1950, que apresenta uma narrativa visual de histórias de exploração racial mescladas com categorias de luta de classes (ver figura 1).

Quando o projeto de desenvolvimento se apresenta como rota de fuga da dependência do "Centro" para as economias da "Periferia", aquelas velhas características -miséria e pobreza- parecem se atualizar e se traduzir na linguagem daquilo tudo que vinha sendo 'antropofagiado', ou seja, que vinha sendo digerido e vomitado, resultando uma outra coisa. Não parece estranho, então, que em uma linguagem muito parecida com o vanguardismo do chamado realismo social dos anos 1920, o argentino Antonio Berni estivesse tentando ilustrar a cena proletária da sua cidade na Argentina em 1934 (ver figura 2).

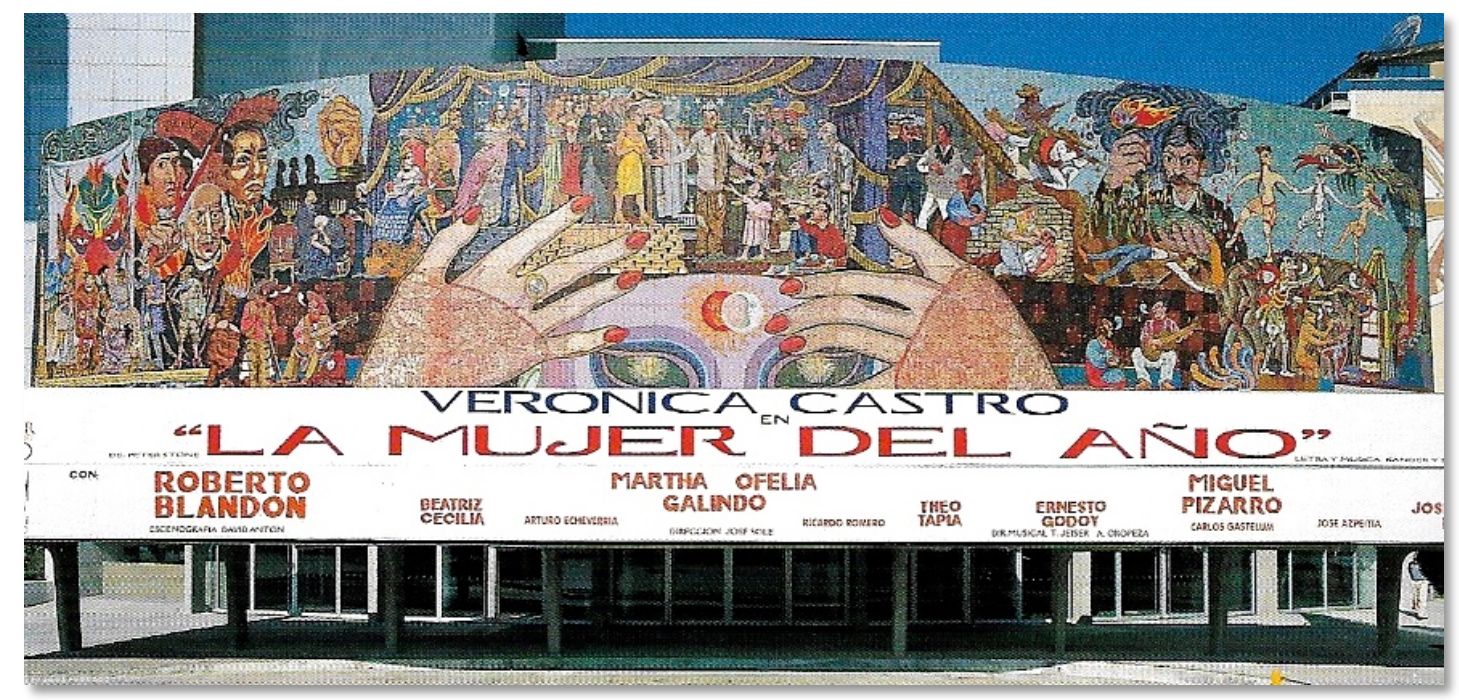

Figura 1. Teatro de los Insurgentes $(12,85 * 42,79$ m.) Diego Rivera 1953, Cidade do México Tomado de Kettenmann (2015) 


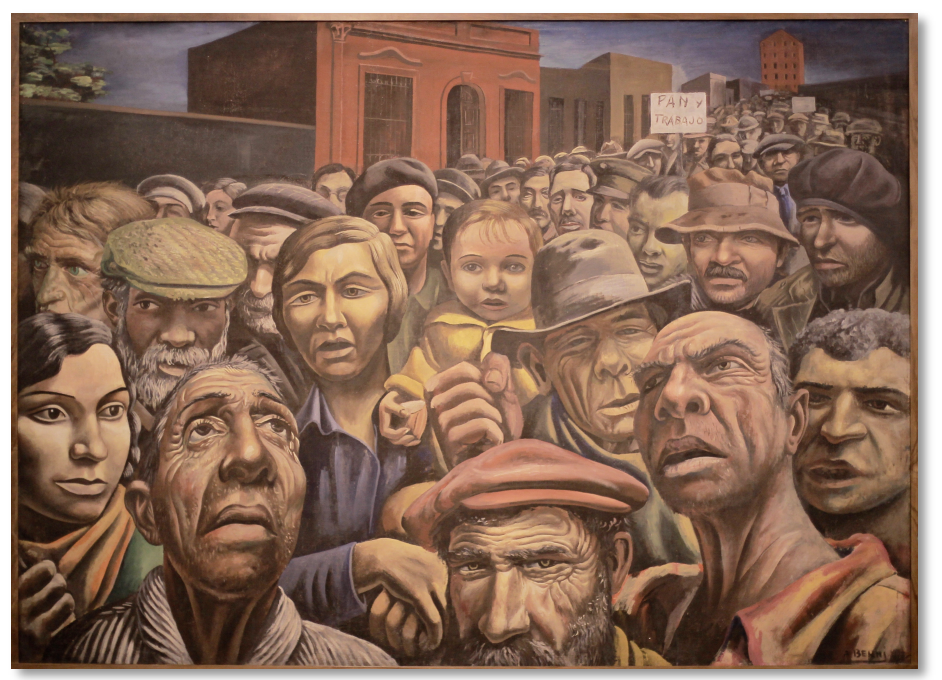

Figura 2. Manifestación $(1,80 * 4,49$ m.

Antonio Berni 1934, Coleção do MALBA (Museo de Arte Latinoamericano de Buenos Aires) Foto por Bibiana Peña

Se a década dos anos 1930 poderia se generalizar como uma década de transição entre aquele tradicionalismo encarnado do século 19 e os ajustes para enfrentar os desafios da modernização dos Estados, as economias e as sociedades no sentido mais amplo, poderia dizer que os anos 1940 permitem pensar no delineamento desse processo como um caminho mais equilibrado para todos os agentes sociais. Bom, 'todos' é retórico. Observar os mecanismos de exclusão sistemática de atores que não se submetiam ao corporativismo promovido pelo Estado, mostra que a tentativa de ampliar a base social era, na realidade, uma proposição feita de ar.

O desenvolvimento seria o eixo sobre o qual giraria o intuito desde os anos 1940 . Com determinados nomes, esse eixo movimentava a ilusão da autonomia técnica, econômica e cultural das economias dependentes do Centro. Como tal, o projeto abrangente oferecia a oportunidade de concretizar uma sociedade mais equilibrada, na qual as angústias da miséria e da pobreza seriam finalmente superadas. Poderia dizer que o projeto de desenvolvimento incluía o princípio de mudança da realidade, pelo qual se convertia em uma esperança para a grande maioria de intelectuais, artistas, escritores e críticos em geral.

Os acontecimentos se encarregaram de diluir essa promessa, gerando novos flagelos que ameaçavam ainda mais a ideia de equidade. Passando a metade dos anos 1950, as economias da região começaram a mostrar indicadores deprimentes, abalando 
a crença na modernidade. Desaceleração da economia, problemas de marginalidade provocada pelos processos desenfreados de urbanização, entre outros, expuseram a miséria e a pobreza em facetas ainda mais cruas. Se antes disso aqueles problemas eram conhecidos em teoria, a partir desse momento passaram a ser vistos na vida quotidiana das cidades latino-americanas.

Em tais circunstancias Fidel Castro consegue entrar em Havana, gritando ao mundo o triunfo da Revolução que tinha iniciado uns anos atrás. Se no contraluz dos desafios da modernidade, o Comunismo Internacional conseguiu alimentar as imagens de porvir em jovens latino-americanos, as românticas efígies de Fidel e de Che Guevara substituíram as velhas imagens de Lenin, como com sentido histórico menciona o historiador Jaime Jaramillo (2007). Claro, essas efígies eram ícones dos seus princípios renovadores para as sociedades da região. Eram promessas da conquista de um mundo mais justo.

4.

É relativamente fácil entender como os pioneiros do design latino-americano se alimentaram desses princípios de mudança do mundo. Não que eles achassem que o Comunismo ortodoxo ou a Revolução fossem uma opção, ao menos, não na grande maioria e/ou no sentido explicito. Existiam os que efetivamente acreditavam em uma ou outra linha -por exemplo, o argentino Tomás Maldonado que esteve durante vários anos comprometido com as diretrizes partidaristas do Comunismo, ou Iván Espín que fez parte da estrutura burocrática do governo cubano- assim como aqueles que acreditavam na mais diversa qualidade e quantidade de opções do porvir. Assim, dos ortodoxos comunistas, passando pelos revolucionários, progressistas, anarquistas até os corporativistas, todos contribuíram para o fortalecimento do campo profissional do design nos seus respectivos países. No final a ideia de mudar a realidade parece morar no coração do Projeto Moderno e indistintamente do credo, dialoga com a mais densa qualidade de intelectuais latino-americanos.

Um dos vasos comunicantes mais claros na difusão desse princípio é, sem dúvida, a Arquitetura Moderna. Mais a frente aprofundarei. Neste momento, gostaria apenas de mencionar seus pilares disciplinares, embasados tanto na quebra do vínculo entre arquitetura e a escolas de Belas Artes como na sua atualização em torno da ideia de resolver necessidades habitacionais de indivíduos. Entre outras coisas, permite 
entender porque habitantes de lugares tão distantes entre si poderiam conceber e resolver o mundo de formas similares. Não é gratuito que o início da profissionalização do design latino-americano tenha tido proximidade com a arquitetura. Vários -muitosarquitetos da região tiveram experiências com o design de objetos de 'menor proporção' e de comunicação visual, o que acabou por levar muitos deles -dadas diferentes circunstâncias- a redirecionarem seu exercício profissional, por vezes abandonando o trabalho que se esperaria de um arquiteto.

No interior da configuração da ALADI, a arquitetura transpira no decorrer de todo o processo e em todos os níveis. Posso afirmar que entre 90 e 95\% dos membros fundadores eram formados em arquitetura nas diversas universidades da região, nascidos entre 1930 e 1950. Os que não eram arquitetos de formação ou tinham frequentado parte do curso substituindo-o no momento em que surge a oferta de um curso de design -Oscar Salinas, Gabriel Simón, Luiz Blank, etc.-, ou estavam relacionados com o seu exercício por meio de familiares influentes -como no caso de Joaquim Redig cujo pai era arquiteto-.

Ao se iniciar no 'mercado profissional diferenciado' do design -já não da arquitetura ou da publicidade-, muitos desses arquitetos acabaram por se especializar academicamente em projeto de mobiliário, projeto de comunicação visual, produção e gerência. Essas experiências de especialização se deram em distintos níveis de formação e de cursos, com difícil equivalência quando comparados, tanto entre eles, com o sistema acadêmico atual. Enquanto uns fizeram 'cursos de verão', outros se concentraram no que hoje equivaleria ao mestrado. Houve aqueles que frequentaram cursos no exterior, os quais aconteceram em escolas diversas: desde a Escola de Ulm -dois ou três casos-, passando pela Escola $H f G$ de Offenbach, a Universidade de Stuttgart na Alemanha, o Royal College of Arts da Inglaterra, o Massachusetts Institute of Technology, o Pratt Institute em Nova Iorque, a Belmont Adult School dos Ángeles nos Estados Unidos, o Politecnico di Milano na Itália, o Instituto Lahty e a Helsinki School of Economics na Finlândia, etc.

Por sua parte os seus substratos familiares mostram como a maioria deles proveio de núcleos urbanos de classe meia e alta. Não foram poucos os que estudaram em colégios que pretendiam formação de cunho humanístico com ênfases literária e artística -música, arquitetura, teatro e artes visuais-, assim como em crítica política e sensibilidade social. Em sua maioria, faziam parte de famílias 'tradicionais', em que as 
mães dedicavam seu tempo aos assuntos do lar e às causas coletivas que giravam em torno do princípio da caridade. Algumas vezes, eram filhos de mães com vidas profissionais e políticas ativas, sendo jornalistas ou professoras. Os seus pais -na grande maioria dos casos- eram profissionais formados nas universidades da região e até no exterior. Desde advogados e médicos, passando por filósofos, jornalistas e arquitetos, alguns deles com carreiras políticas em seus países, sendo senadores, prefeitos e até mesmo candidatos presidenciais, como ocorreu com o pai de Alejandro Lazo no México. Outros poucos tinham profissões mais técnicas, sendo engenheiros ou comerciantes. Conservadores, comunistas, anarquistas e liberais; católicos, judeus e ateus. O enquadre político e ideológico dos pais e mães dos envolvidos na ALADI configura um heterogêneo espectro de influências, as que em todo caso, parecem ter uma coincidência em comum: uma relativa preocupação com o desenvolvimento da sociedade.

Posso dizer que os envolvidos na idealização do design latino-americano podem representar um determinado tipo de processo no qual o arrivismo da elite vai mudando. Um processo que vai desde das tendências em carreiras como advocacia e a medicina até mesmo engenharia- que podem caracterizar as decisões agregadas à formação das gerações de latino-americanos a partir da segunda metade do século 19 (Safford, 1989; Uricoechea, 1999), quanto ao aparecimento da Arquitetura Moderna na região e a sua derivação no campo do 'design'.

Um assunto que parece mostrar um interesse diferenciado pelo prestigio social -a ideia da substituição do título aristocrático pelo título universitário, como menciona Larson (1977)- misturado com a maneira de mudar o mundo, com a qual sonhava a intoxicada geração de jovens estudantes dos anos 1960. A partir daí, a Arquitetura Moderna e o Design -desprendido dela- parecem 'simples' promessas seculares. Nisso, os Sigfridos -São Jorge- tomam partido. ${ }^{1}$

\footnotetext{
${ }^{1}$ A figura retórica do Sigfrido - São Jorge é uma ironia usada por Colin Rowe (1978), quando tenta mostrar como é que os arquitetos modernos se enfrentam ao maneirismo em que caiu a arquitetura dos anos 1950, muito em contra dos seus próprios postulados e princípios heréticos.
} 


\section{Proveniências e desprendimentos}

1.

A partir do mencionado acima, me parece que seria possível afirmar que o design entre outras variadas e heterogêneas linhas genealógicas- se desloca de dois grandes núcleos na região. Para seguir na minha linha argumentativa e não necessariamente seguindo a ilusão cronológica, a primeira é aquela que reúne os ideários, preocupações, técnicas e sistema de ensino da Arquitetura Moderna. De diferente maneira, as explorações dos arquitetos que alcançam o exercício do design de produtos e sistemas de comunicação visual, o faziam oferecendo resoluções amplas de projeto -como com sentido sociológico expressa Ricardo Blanco (2016)-, bem pela imperiosa necessidade por resolver situações que a sua formação não havia abarcado.

Na primeira situação, os projetos de Arquitetura Moderna que se multiplicavam na região durante os anos 1940 e 1950 sistematicamente buscavam a comodidade garantida por meio do design de todos os objetos inseridos em determinado projeto. 0 ideal moderno da habitação seria, provavelmente, a base dessa preocupação, quem sabe se tendo o trabalho e as reflexões de Frank Lloyd Wright como principal referência. Vários casos de moradias na América Latina reproduzem os ideais delineados por expoentes da Arquitetura Moderna nos Estados Unidos e na Europa -ainda de forma simultânea e até precursora- como a Casa Modernista de Gregori Warchavchik em São Paulo em 1928, passando pela Casa Lozano de Heladio Muñoz em Cali em 1947 e a Casa Curutchet de Le Corbusier e Amancio Williams em La Plata em 1953.

Os ideários modernistas da arquitetura cruzavam os oceanos, chegando aos cantos mais recônditos da América Latina, quase sempre por meio de viagens desses indivíduos expoentes. As travessias desses sacerdotes, pelos mais diversos motivos -praticamente todos os Arquitetos Modernos pioneiros visitaram o México, a Colômbia, Cuba, a Argentina, o Brasil, o Peru, etc.- , assim como as passagens de jovens arquitetos latinoamericanos por seus escritórios e/ou aulas. Ideários, técnicas, sistemas de resolução atualizaram os procedimentos e os sentidos do ofício arquitetônico. 0 arquiteto modernista tinha como propósito o projeto de uma obra que permitisse a comodidade, dedicando rigorosa atenção aos detalhes do projeto em todas as suas escalas: desde a 
macro-dimensionalidade do espaço, passando pela equivalência dos objetos, até chegar naqueles que são manipulados entre as mãos, os chamados micro-objetos. ${ }^{2}$

Em certo sentido o arquiteto tinha como objetivo abarcar todos esses níveis de detalhe por diferentes razões. Com o propósito de elaborar um projeto que garantisse o bem-estar, o estilo rigoroso buscava o desdobramento da 'cultura material' como um esoterismo que pretendia alinhar sentidos e esforços; era o caminho para a conquista do porvir. No caso de vários projetos desse período, aquele que projetava a casa acabava por detalhar desde cadeiras até talheres. Com o passar do tempo, essa prática abrangente deu lugar a especialidades profissionais, criando novos campos autônomos para o exercício profissional e, em decorrência disso, criando a necessidade de atualização do ensino. É interessante ver como vários cursos de Arquitetura Moderna se confrontaram com esse desafio no início da década dos anos 1960 na região. No capítulo 4 aprofundarei alguns desdobramentos, principalmente pelo fato de a Arquitetura Moderna ser um dos vasos comunicantes. Por enquanto, compreendendo nela um núcleo de deslocamento do campo do Design, menciono três instituições: a Faculdade de Arquitetura e Urbanismo da Universidade de São Paulo3 , a -naquele momento- Facultad de Arquitetura da Universidad Nacional de Colombia em Bogotá e a Facultad de Arquitetura da Universidad Nacional Autónoma de México. Com os seus respectivos antecedentes e enfoques, durante os anos 1960 essas três escolas enfrentam o desafio de compreender essas novas especialidades como habilidades do Arquiteto Moderno. ${ }^{4}$

2.

Uma outra opção seria que o deslocamento da matriz do curso e da profissão também estivesse relacionado com falências crônicas na estrutura da arquitetura como sistema de pensamento e como ofício. Entre outros, Colin Rowe (1978), Sergio Ferro

\footnotetext{
${ }^{2}$ Aquelas três categorias provêem da antiga classificação de objetos que propus Abraham Moles desde finais dos anos 1960. Num esforço por fazer uma tipologia geral, ele decide utilizar a escala como mecanismo de classificação (Moles, 1975).

${ }^{3}$ Sugiro revisar o trabalho de Renata Siqueira (Siqueira \& Braga, 2009) e Dora Dias (2014, 2014a) no relacionado com a USP brasileira. Cada uma delas estuda a configuração das sequências de design que são incluídas na grade curricular do curso de arquitetura em 1962.

${ }^{4}$ Menciono essas três como simples ilustração. 0 debate estava aberto naquela época em boa parte das escolas de arquitetura da região, como é possível ver das reuniões das Conferencias Latinoamericanas de Escuelas y Facultades de Arquitectura . Por exemplo em 1964 no encontro em Córdoba Argentina, uma das conclusões relacionava a conquista do conforto com a necessidade de fortalecer algumas especialidades para o arquiteto, como o design industrial (Subcomisión-1,1964).
} 
(1982), Adrian Gorelik (2005) e Otília Arantes (2001) assinalaram determinados vícios e engendres nas formas em que a Arquitetura Moderna se pensou, viralizou e implementou. Seja no maneirismo que marca Rowe no início dos anos 1960 -cedo demais-, na alienação mostrada por Ferro nos inícios da especulação imobiliária na América Latina desde a segunda metade dos anos 1970 ou a 'simples' descontextualização que significava a industrialização do Estilo Internacional que criticam Gorelik e Arantes, as outrora premissas centrais da Arquitetura Moderna terminaram por desiludir toda uma geração de indivíduos comprometidos ideologicamente com a mudança do mundo.

A Arquitetura Moderna tinha se oposto ao espírito especulativo na forma, na qual as obras arquitetônicas eram definidas a partir da réplica de modelos considerados apropriados e formosos. Os ideários modernos de conforto e bem-estar invadiram a jurisdição arquitetônica trazendo questionamentos sobre seu lugar no mundo moderno. Dessa forma, que talvez a grande ideia de Lloyd Wright acabasse por ser levada em alta conta.

Tanto a concepção do 'arquitetônico' quanto o ofício se tornaram heréticos -como diz Peter Gay (2007)-, principalmente pelo fato de se opor a sua própria origem: a romântica ideia das Belas Artes. E sendo heréticos, era promissórios. Para aqueles que sonhavam com um mundo de muros brancos aonde ninguém se preocuparia mais pela impureza e a imperfeição da vida -como profetizava Adolf Loos- a obra arquitetônica se tornava a melhor de todas as obras... era uma "máquina para habitar".

Talvez, por causa disso, é que resulta tão paradoxal o fato de que lutando contra a repetição indiscriminada de modelos formais, um cubo acabasse sendo uma opção de habitação, um prédio de escritórios ou uma loja, como ironizava Rowe (1978). Nesse ponto terminal, a função já não determina a forma. Muito ao contrário, além de abandonar o sentido que orienta a sua existência, essa passa a ser replicada como modelo, da mesma maneira em que o estilo romântico, neoclássico ou até mesmo o estilo inspirado na arquitetura de paládio, foi reproduzido durante o século 19 , quando a heresia nascia como reação a essa realidade.

Mas se aquilo podia ser considerado uma traição, a situação se tornaria pior quando atrai interesses de especulação econômica. A facilidade com que se produzia 'o estilo moderno', dada a forma, os materiais e a noção de projeto, em conjunto com as necessidades e a ansiedade dos governos desenvolvimentistas da América Latina 
naquelas décadas, acabam por ser vistas como oportunidade de lucro que não seriam desprezadas. Em decorrência, várias perversões acabariam por se materializar: desde a perda do sentido fundamental pelo qual eram pensadas essas obras arquitetônicas agora deslocadas para satisfazer ideais de rentabilidade- até a maneira como se dava a divisão do trabalho e o jogo do prestígio no exercício de construção. Para o que está comprometido com o ideário de uma sociedade próspera para todos, a entrada em cena do "doutor-capital" -como o chamava Ferro- era o sinônimo mais evidente e doloroso da alienação.

Aliás, se existe um bafo incômodo nesse maneirismo e nessa alienação, o latente arrivismo das elites latino-americanas se tornou o fato mais complicado de digerir pela crítica dos ilusionados. Elas -as elites- compraram um modelo de desenvolvimento dentro do qual até mesmo o estilo arquitetônico estava predeterminado. Estando predeterminado e sendo externo às situações, materializava o princípio de "reformismo conservador", com o que Góreilk caracterizou as operações dos governantes regionais. Dessa forma, toda a heresia encontrada na emancipada Arquitetura Moderna, terminava reduzida em exercícios que além de maneiristas eram sinônimo da infiltração de ideias estrangeiras nas realidades das condições latino-americanas. Os catálogos estavam prontos e -agora, a diferença do tradicionalismo pré-moderno- a elite latino-americana pretendia usá-los como estratégia para se fortalecer e legitimar sua posição no centro do nacionalismo, que por sua vez era o centro do projeto desenvolvimentista. Permito-me citar um parágrafo de um artigo meu publicado em 2013, no qual sintetizei o que pretendo expressar

[...] De las críticas al formalismo y a la alienación se pueden desprender algunas consecuencias generales en cuanto al proceso de implementación del modernismo en América Latina. Una de ellas está relacionada con la descontextualización. La aplicación del proyecto arquitectónico terminó privilegiando en la región proyectos y necesidades sociales que muchas veces no sintonizaban con la realidad de sus países. Esto supone la desilusión de varios arquitectos frente a lo que es vivido como una "traición" a uno de los baluartes más grandes del modernismo en la Arquitectura. Con o sin crítica que lo afirmase, ahí estaban los edificios y los proyectos para confirmar que el sentido de la creación arquitectónica no era cubrir las necesidades habitacionales de la mayoría ni la promoción del desarrollo para todos. Si todo esto se desarrollaba en una escala menor, la mayor decepción fue la comprobación de que la Arquitectura latinoamericana terminó construyendo la imagen de los reformismos conservadores, apoyando los planes de burguesías superficiales, arribistas y culturalmente dependientes, en especial de los Estados Unidos (Buitrago \& Braga, 2013, p. 177). 
À contraluz da crítica sobre a Arquitetura Moderna, me parece plausível pensar que as ideias anteriores pudessem estar presentes na mente de alguns dos arquitetos que pretendiam sucesso no mercado profissional a partir da segunda metade dos anos sessenta. Digo presentes, mas me parece necessário matizar o nível de consciência. Naquele momento quase que não era perceptível, porque essas práticas estavam em seu auge. Mas, com o passo do tempo, essas características críticas começam a ser visíveis, especialmente para aqueles que se deram a oportunidade de refletí-las. Contudo, ainda que não sejam conscientes, não significa que não fossem sentidas ou percebidas em um nível diferenciado de consciência

[...] Pienso que en ese momento aún no, en el sentido o con los alcances de los años posteriores y actuales [...] la gente que salía se ocupaba y tenía claridad sobre su desempeño. Sin entrar en los debates de los arquitectos sobre el asunto, pienso que en aquellos años no había una crisis verdadera, sino que esta viene justamente más adelante, tanto en el ejercicio como en la academia [...] Ahora bien, como sucede en otras carreras, los fenómenos económicos y tecnológicos nunca van a la par con el desarrollo de las disciplinas: eso no va parejo. Ahí es donde yo entiendo que viene el desajuste, pero se presenta de los setenta para acá con toda seguridad (Polo, 2014a).

\section{3.}

Como categorias, essas dimensões me permitem traçar um panorama de crise na estrutura do campo profissional -a Arquitetura- que, por sua vez, acaba por impulsionar a emancipação de um novo campo -o Design, principalmente o Industrial-, em decorrência de atualizações e especializações que denunciam a gradual complexidade da sociedade. Porém, reduzir a análise a esse ponto é forçado e termina sendo abusivo. Existem outras explicações para essa 'emancipação' que acabam sendo tão prosaicas quanto legítimas. Para mencionar uma, me parece interessante notar como de diferentes formas os Estados latino-americanos estimulam as condições para a existência do design como campo diferenciado.

Sem uma proposta anunciada mas com uma imbricada rede de circunstâncias como assessoramentos e receitas internacionais- os Estados promotores do desenvolvimento nacional, promovem a criação de escritórios, planos, projetos, institutos, etc., que por sua vez e de forma direta, exigem o exercício da profissão que seria conhecida como Design. Mais a frente aprofundarei esse raciocínio, mas diferentes 
agências nacionais procuraram, nesse momento, profissionais aptos ao desenvolvimento de determinados projetos, que na prática, e dadas as condições do mercado profissional do momento -anos sessenta- podiam ser levados a cabo por artistas visuais ou arquitetos. Esses últimos, na grande maioria dos casos na Colômbia, no México, em Cuba, na Argentina e no Brasil -pelo menos-, receberam o chamado iniciando processos de aprendizagem das 'discricionalidades' do design enquanto desempenhavam alguma outra função técnica no interior de alguma dessas agências nacionais.

Dessa forma, se jovens arquitetos aborrecidos com a decadência de sua profissão no sentido da sua coerência social, podiam sentir remotamente vontade de se revoltar contra o núcleo de sua prática e se afastar dele desempenhando um outro ofício -um que cumprisse as promessas modernas que o exercício arquitetônico havia traído-, é claro, que as oportunidades simplesmente apareciam nas suas vidas, desenhando um panorama de desempenho profissional desconsiderado como opção até aquele momento. Esses desvios, enxergados como possibilidades, efetivamente mostram uma opção que por sua vez exibem as virtudes do Design como disciplina coerente com o desenvolvimento nacional. Um ofício que se alinhava com as categorias que cada um deles tinha instaladas em seus raciocínios. Vários fundadores da ALADI descobrem a sua relação com o design pelos caminhos da experiência, na qual embasam as suas futuras reflexões.

4.

Acompanhando o percurso da Arquitetura Moderna, o segundo núcleo a partir do qual pode se desprender a profissionalização do Design na região, é um pouco mais antigo e complexo. Parece-me que ele é mais reflexivo que profissionalizante, podendo se revelar como narrativa de manifesto. Em comparação com o matiz profissionalpolítico que mencionei acima da arquitetura nos itens anteriores -que parece mais preocupado com as condições dos países da região, em especial o fortalecimento do projeto de desenvolvimento-, um matiz de maior destaque estético-político é aparentemente considerado como base para raciocínios mais internacionalistas ou se é preferido, mais cosmopolitas. Os esforços conceituais para se pensar o que seria o chamado 'Design' estavam em grande parte sintonizados com discussões mais abstratas, como princípios da filosofia da ciência e/ou da técnica ou relações entre a cotidianidade, a beleza e o conforto, claramente propostas pela discussão geral da modernidade. 
A mim me parece que ao menos dois pioneiros foram fundamentais para os antecedentes reflexivos -teóricos e conceituais- da jurisdição e a defesa discricional do Design na região: a cubana Clara Porset, nascida em Matanzas em 1895 e formada como arquiteta e designer nos Estados Unidos e Europa, que cruzou em seu caminho personagens da Bauhaus como Joseph Albers e Hannes Meyer, e o argentino Tomás Maldonado, nascido em Buenos Aires em 1922 e uma das referências teóricas mais importantes, quanto a problemas do design em escala mundial.

Ambos, provenientes de famílias de classe alta nos seus países, acabam por participar como militantes do Partido Comunista estando fielmente comprometidos com a ideia de mudança da realidade. Os dois antecedem a publicação de textos relacionados com teoria do design na região. Com as precisões que resultam necessárias, é nos últimos anos da década de 1940 que cada um publicou, respectivamente, o seu primeiro artigo, em que reflexionam sobre o significado do design, assim como o seu papel social no sentido mais abrangente (Simón, 2013). Esses escritos transitam -de formas distintas- entre o debate da beleza, da industrialização das artes e da vida quotidiana.

Também -cada um em seu contexto- se dedicaram a ofícios que seriam associados ao conceito de designer. Porset se dedicou mais ao mobiliário e Maldonado, à gráfica. 0 caminho de Porset a levou à Cidade do México, na qual se instalou e onde integrou-se à elite artística moderna do país. Entre outros, foi responsável pela primeira exposição de design de objetos no México no Museo de Bellas Artes em 1952 chamada "El arte en la vida diaria. Exposición de objetos de buen diseño hechos en México". Pode-se dizer que suas motivações se aproximam às preocupações da Bauhaus, parecendo interessada em criar uma ponte entre a produção artesanal -profusa no país- e os nascentes princípios do design internacional

[...] La intención de la diseñadora era conjuntar en un mismo espacio los productos artesanales realizados en México y aquellos realizados en serie. Lograr un vínculo entre la industria, los artesanos y los artistas con el fin de tener mejor diseño y lograr implementar la producción industrial (Mallet, 2013, p. 9).

Além disso, Porset está gravitando em torno algumas ideias do governo cubano nos inicios dos anos 1960, especialmente do Che Guevara -nesse momento, interessado no estabelecimento de uma escola para formar profissionais para lidar com esse tipo de questões-. Nós, hoje, sabemos que essa questão -o debate acerca da beleza, arte industrial, conforto- se compreende para uma linha de raciocínios como a síntese de 
onde nasce o Design como especialidade autônoma. Essa tentativa será adiada e posteriormente direcionada, com outros termos, por outro cubano em 1970: Iván Espín.

Maldonado se tornou conhecido como o grande teórico do design mundial. Não acredito que essa ideia seja exagerada. Por um lado, ele é um dos poucos que refletiram acerca do problema do design a partir de 'noções duras', próprias de determinadas linhas de pensamento da filosofia, sobretudo, como notório, da chamada Filosofia da Técnica e da Tecnologia. De outro, parece que os problemas que pretendia abordar sobretudo na sua juventude- giravam em torno de assuntos sociais maiores, relacionados à Modernidade, à qual o Design estava circunstancialmente envolvido. Uma estreita relação entre as concepções estéticas e as suas relações políticas, como é possível afirmar a partir dos trabalhos de Devalle $(2009 ; 2014)$ e Lucena $(2012 ; 2015)$.

Considerando o trabalho reflexivo de ambos, é possível dizer que servem de base para sensibilizar discussões, discípulos e processos institucionais relacionados ao design. Mas, é preciso considerar que, existe ao menos uma diferença importante nas formas como refletem e atuam em relação com a questão, uma diferença que poderia se explicar pelo contexto, mas que, ao mesmo tempo, ao vê-la presente nos cantos da região resulta um estruturalismo tolo. Parece que ambos, tanto Porset quanto Maldonado, são cosmopolitas no sentido lato e que estão interessados em participar de uma discussão internacional que desconhece territórios e se relaciona com os princípios e a busca de um novo mundo. Contudo, enquanto Porset caminhava pelo trilho da procura nacionalista -como feito pelos colegas mexicanos que naquele momento a rodeavam-, Maldonado estava comprometido com uma busca desprendida de lugares... é um "comunista humanista” como contundentemente defende Verónica Devalle (2016).

Para Porset, é claro que a tradução do local era um dos fundamentos mais importantes para a conquista da modernidade. Após o seu contato internacional com os preceitos modernos norte-americanos e da Bauhaus, ela retornou ao seu país com a compreensão de que a forma mais coerente de ser 'moderna era ser nacional', como defendia Oswald de Andrade (García-Canclini, 2015). Vários dos seus trabalhos evidenciam essa busca, tanto em Cuba, como no México. Um dos seus trabalhos mais famosos é a cadeira Butaque, que poderia ser considerado como o mais conhecido ícone desse esforço da cubana (ver figura 3). Por sua vez, Maldonado foi um tenaz crítico das localidades. Intoxicado por seu internacionalismo, para ele era mais importante a configuração de uma linguagem visual contundente e coerente com o chamado histórico 
da humanidade. Iconoclasta, não só se afastou da procura das manifestações de localidade como também considerava imoral a representação figurativa.

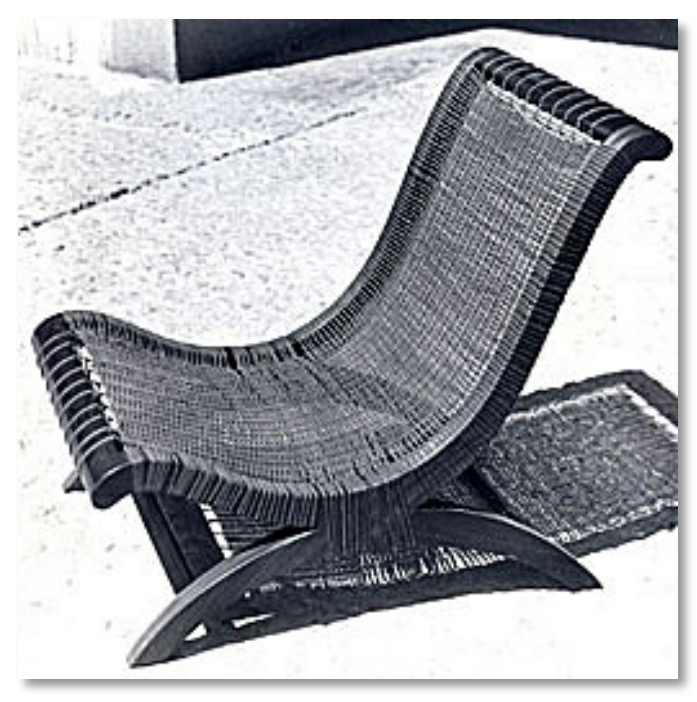

Figura 3. Butaque, Clara Porset 1956, Imagem do livro de Oscar Salinas et al. (2007)

A diferença parece pequena e aparentemente insignificante, mas não é. Diversas correntes de pensamento na região poderiam ser relacionadas com o mote de Oswald de Andrade realçado por García-Canclini (2015). A lista é comprida e as suas obras são visíveis, aplaudidas e famosas. A ideia de ser nacional para ser moderno era colocada na busca do local, o nativo e/ou o originário como via para o realce da própria identidade. Contudo, também existiam grupos de intelectuais que pensavam de forma mais geral. Para eles ser moderno era se inscrever nos debates universais da modernidade em si. Eram latino-americanos que, por diferentes razões, não queriam abandonar a ideia de participar do que acontecia nos 'centros culturais do mundo'.

Isso se manifesta de diferentes formas também, variando conforme as múltiplas circunstâncias que se dão nos distintos lugares. Desde as ideias herdadas das elites que não queriam perder as suas ligações com a Europa -característica marcante do arrivismo em setores das elites latino-americanas como afirma Brunner (1995)-, até os diferentes cruzamentos ideológicos vistos nas sociedades latino-americanas a partir do avanço do populismo durante os anos 1940. Desde o capricho em não perder as maneiras europeias -"hubo un sector que no estuvo dispuesto a abandonar su gusto por las tendencias, la moda, las obras y los acontecimentos" (Mallet, 2014, p. 25)- até a ideia 
de que o contrario seria atraso: "la lucha contra el gobierno se dirime en la causa de la civilización contra la barbarie; para quienes defienden sus políticas [...] la Nación, su Pueblo y la justicia social contra el cosmopolitismo" (Lucena, 2015, p. 156). A primeira citação no debate nacionalista mexicano, a segunda, parte do discurso peronista argentino.

Assim, enquanto Porset inaugurava a exposição de 1952 e trabalhava com cuidado 'na tradução' dos ícones populares na linguagem moderna, Maldonado se dedicava às suas experimentações no concretismo, 'descobrindo' o design enquanto atualizava as suas reflexões. Em parte, aí respira a luta entre o nacional e o cosmopolita. 0 enaltecimento 'do popular' no centro do trabalho de vários grandes artistas latinoamericanos desde os anos 1920. Porset se 'expressava como artista industrial'. Maldonado, não só não reproduzia ícones do orgulho nacional, mas julgava duramente a prática de seus colegas e mestres que o faziam. Lucena (2015) menciona como Maldonado brigou com o seu mestre, o uruguaio Joaquín Torres García, por causa da representação de elementos alusivos ao território na sua obra

[...] El constructivismo uruguayo es el ejemplo típico de la mezcla ecléctica. En las obras constructivas de Torres García encontramos cubismo (mal cubismo), impresionismo, cocina del siglo XIX (sobre todo eso) y simbolismo barato (soles, muñecos pictográficos, pescaditos). Maldonado, 1946 (Lucena, 2015, p. 53). ${ }^{5}$

\footnotetext{
${ }^{5}$ Maldonado também se afasta do Partido Comunista argentino, dadas as irreconciliáveis diferencias iconográficas que tinha com as diretrizes centrais do partido. Resumindo, Maldonado não faria mais fotomontagens para a propaganda do partido no seu país, dada a exigência no uso de imagens realistas. Recomendo ver o texto de Lucena sobre o assunto (2012).
} 


\section{Um projeto emancipador}

[...] El proyecto arquitectónico necesitaba del desarrollo del mobiliario. En un momento determinado, esa tarea la desempeñaba el mismo arquitecto. Pero con el paso del tiempo, esa tarea se especializó convirtiéndose en un área emancipada, que luego comenzamos a llamar diseño (Blanco, 2016).

\section{A velha toupeira}

1.

Em 1987 Alain Touraine publicou El regreso del actor. Nesse livro, ele defendia a ideia da participação social como motor da democracia na América Latina (Touraine, 1987). Uma de suas teses, da qual sempre recordei, foi a ideia de compreender na ação social a base da mudança, considerando os níveis de legitimidade que representava a sua causa e a 'espontaneidade' como produto de agentes que a reivindicavam. A mim me parece que a minha lembrança desses conceitos está relacionada à figura retórica usada por Touraine para expressá-la. Sempre me pareceu que ela é tão dilapidaria, como irreverente e provocadora. Como se acabassem as palavras, ele diz que o ator não deve ser visto como um anjo que pousa iluminando a realidade com a sua pulcritude e a sua aura de perfeição, mas deve ser visto como uma velha toupeira que confecciona em baixo da terra os diversos caminhos pelos que transita. As ideias de determinismo, predeterminação e até de projeto ficam bem questionadas.

Além de uma latente homenagem que possa fazer a Touraine, me parece que sua metáfora descreve com relativa precisão parte do processo de profissionalização do design na América Latina. Da forma como eu vejo, tanto o ofício como o mercado profissional do design latino-americano -ainda que relativamente simultâneo nos diferentes países da região entre eles- se deram, se configuraram, se formaram em torno de respostas isoladas -quem sabe se espontâneas- a determinadas necessidades que manifestas pelas mudanças impulsionadas pela modernização. Quiçá, por isso vários tipos de profissionais se envolveram em exercícios que paulatinamente serão caracterizados como práticas especializadas do design: desde o pioneirismo na projetação de móveis e peças de gráfica publicitária e de comunicação visual até -como 
acontece ao passo do tempo- o design de objetos para o lar, o design editorial, entre outros. Essa atividades eram necessidades que se manifestavam no cotidiano social desvinculado das imposições conceituais que as reflexões estéticas, políticas ou sociais de disciplinas e exercícios modernos pudessem conduzir.

Essa forma de especialização foi um caminho mais ou menos comum dos processos de profissionalização desse campo moderno. Vários dos teóricos das profissões justificam a mudança de ofícios e disciplinas mais velhas como um dos núcleos fundamentais de deslocamento para explicar o nascimento de novos campos profissionais. Dessa forma -por exemplo- as linhas tradicionais de artífices marceneiros são antecedentes diretos no exercício de determinados profissionais -principalmente arquitetos- que projetavam móveis modernos desde os anos 1940 em São Paulo, Bogotá, Lima, Buenos Aires, Havana, Caracas, Cidade do México, Santiago, etc. Antecedentes tanto na linha histórica, quanto na sua interação. É dizer, tanto na diacronia que representa o passo do tempo e a 'sugerida substituição' no exercício de um pelo outro, quanto no trabalho simultâneo entre uns e outros. É interessante ver como essa prática desenhou novas dimensões para o problema. Se nos finais dos anos 1800 um marceneiro era o princípio e o fim da produção de uma peça -cadeira por exemplo-, nos anos 1940, ele aparece como complemento estritamente produtivo das concepções de algum outro. Uma evidência da divisão social do trabalho. Há casos em todo tipo de ofício, possivelmente em todo território, a espera de registro e problematização historiográfica. ${ }^{6}$ Claro, também é visto como determinados ofícios atualizaram a sua prática se transmutando conforme as exigências das circunstâncias e necessidades.

Parte dessas circunstâncias, foram chamadas de evolução tecnológica, que -como o que mencionei de Marx- converte o ser humano em apêndice da máquina (Marx, 1972). Nessa perspectiva evolutiva, é fácil supor o que acontece àqueles que não se ajustam às condições: a extinção. Outras características dessas circunstâncias foram a substituição dos outrora sistemas de prestígio social. Para teóricos como Larson (1977), os títulos acadêmicos entregues pelas instituições educativas desde o século 19, rapidamente viraram substitutos dos anteriores títulos nobiliários. Sem muito problema, um burguês em ascensão, ainda que não conseguisse obter o título aristocrático que lhe permitisse a

\footnotetext{
${ }^{6}$ Com dificuldade, pretendo fugir das "regressões sequenciais" das que fala Pierre Bourdieu. Nesse seu esquema, um evento explicado pelas condições históricas que o produzem, pode ser consecutivamente explicado pelas condições históricas de produção delas e assim sucessivamente (Bourdieu, 2010).
} 
ilusão de pertencimento a um seleto grupo social, poderia se converter em médico ou advogado, manobra que lhe permitia ser parte de clubes formados de pessoas que, como ele, estavam tentando ascender e se afirmar na escala social. As questões relacionadas ao prestígio nobiliário são enfrentadas a partir das revoluções do século 18 e seguem com os posteriores processos de secularização no Ocidente. Como na história da humanidade, pode ser que a forma tivesse mudado, mas o problema seguia latente. 0 que me interessa destacar aqui é que a formação profissional vira significante para boa parte das burguesias europeias e americanas, tanto do norte, quanto do centro e do sul. Era uma das mais claras opções para recriar as camadas sociais na qual estavam ou pretendiam estar, mesmo que nunca houvesse prática ao título ostentado. Em certo sentido, essa significação ainda ronda os esoterismos relacionados com o título profissional, assim como os níveis e as formas de relação entre pessoas.

2.

Nesse caminho de gradual especialização é mais ou menos fácil perceber que campo do ofício do designer -o que se poderia chamar de mercado profissional- se configurou em grande parte da região a partir dos anos 1950. Não importando enclaves e procedências acadêmicas, vários arquitetos, alguns artistas e um ou outro tipo de profissional, em conjunto com indivíduos talentosos treinados pela experiência -como os outrora mestres artífices- enfrentaram encargos ou projetos que foram sendo incluídos na jurisdição do design de expectativas modernas, bem como de projeto de produto, de comunicação visual ou até de vestuário e modas. Dependendo do país, poderia se pensar na complexidade tecnológica desses encargos e projetos.

É possível notar como esse exercício se iniciou com relativa frequência e rigor em países como -entre outros- o México, Argentina, Brasil, Chile, Colômbia e Venezuela, mas igualmente em países com PIBs tradicionalmente menores como a Guatemala, Cuba, Costa Rica, Porto Rico, Uruguai entre outros. Digo também que tanto a complexidade como a proporção e o volume de projetos variasse entre países, dados os seus próprios processos de modernização, sua heterogênea história e os seus vínculos com o chamado Centro. Talvez o volume ou, quem sabe, a complexidade expliquem o início diferenciado de cursos acadêmicos de design em instituições acadêmicas em determinados contextos.

Nomes como Horacio Durán, Jesús Virchez e Óscar Hagerman no México, Jaime Gutiérrez e David Consuegra na Colômbia, Amancio Williams e César Janello na 
Argentina, Aloísio Magalhães e Lina Bo Bardi no Brasil, Olga Fish no Equador, entre outros que constituíram uma constelação de designers de oficio nos mais diversos cantos da região, desempenharam diversos tipos de projetos alinhados com as expectativas modernas da concepção e da produção. Com determinadas variações, eles nasceram durante as primeiras décadas do século 20, dialogando diretamente com os debates dos anos 1940 e 1950. Vários também -como que dando vida à tese de GarcíaCanclini (2015)- problematizaram o modernismo apreendido se questionando quanto às condições dos seus contextos. Dessa forma, para a maioria deles o modernismo -com o seu catálogo de formas, conceitos de produção e princípios de reprodução- virou a linguagem por meio da qual era possível procurar o sentido das obras nas circunstâncias das suas realidades.

Dessa minha lista, nem Lina, nem Olga nasceram na região. A primeira nasceu na Itália em 1914, migrando em São Paulo em 1946. Fish por sua parte, nasceu na Hungria em 1901, se trasladando para Quito em 1939. Da mesma forma, Hagerman -muito mais novo- nasceu na Espanha em 1936 e migrou ainda criança para Cuba e, logo depois, para o México aonde se estabeleceu desde a sua precoce adolescência.

É fácil encontrar nos seus trabalhos um certo comprometimento com a procura e o realce 'do local', seja esse compreendido como os povos originários, os camponeses ou os artífices, como quem pretende atualizar as formas e os sistemas de resolução material, para que não desapareçam no avanço da modernidade. Se posso dizer aqui, uma espécie de reflexo do trabalho daquela linha de artistas visuais e até literatos modernos latino-americanos que alguns anos antes já tinham começado aquela empresa nas suas respectivas maneiras e sistemas de expressão e representação. No capítulo 4 voltarei a essa questão e a contornarei com mais detalhes.

Vale mencionar que, fazendo uma comparação arbitrária, pode ser incomparável o caso do famoso mural mexicano de Diego Rivera no "Teatro de los Insurgentes", que mostrei em páginas anteriores (ver figura 1) com a projetação da cadeira "Arrullo" de Oscar Hagerman. A origem de cada um deles como projeto é radicalmente diferente, assim como o que é pedido e entregado em cada caso. São dois tipos de produção humana, que transitaram o seu próprio caminho. Para Rivera existia uma necessidade de seguir recriando a mexicanidade frente a ameaça que significava a 'modernização cosmopolita' de Miguel Alemán, como parece estar sugerindo Kettenmann (2015). Um 
'memorial' que ensinasse permanentemente o valor do passado, recuperando uma iconografia originária e popular daquela mexicanidade.

No seu caso, para Hagerman -em 1970- a oportunidade de fazer rentável a linha de produção de um objeto-mercancia para a Sociedad Cooperativa Artesanal Don Emiliano em Nezahualcóyotl, acima da permanência de um 'símbolo popular'

[...] Cuando conocí a las personas de la Sociedad Cooperativa Artesanal Don Emiliano, en la Ciudad Nezahualcóyotl, eran un grupo de carpinteiros que hacía cajas de muertos. Me dijeron que era mucho trabajo y que ganaban muy poco, entonces les propuse: ¿por qué no hacer muebles? [...] Para "La Coope" diseñé la silla Arrullo, inspirada en una de las sillas populares de México [...] Unos carpinteros de Opopeo, Michoacán [...] compraron la silla y la llevaron a su tierra. Hicieron miles de sillas y las vendieron en carreteras, mercados, camellones y calles de todo el país. La silla Arrullo partió de un diseño popular y regresó a la gente. Oscar Hagerman (Hagerman, O. et al., 2014, p. 142 e 144).

A mesma ideia é expressada por Hagerman na entrevista que me cedeu na Cidade do México (Hagerman, 2016).

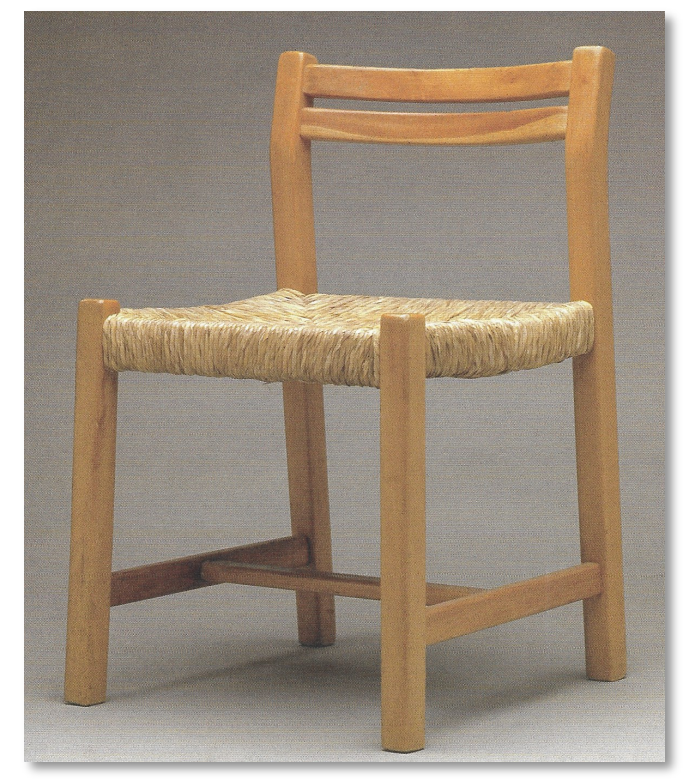

Figura 4. Silla Arrullo, Oscar Hagerman 1970 "Madeira de pino ensamblada y asiento tejido de tule" (Hagerman, Poniatowska, \& Vera, 2014, p. 145) Imagem do livro de Hagerman et al. (2014)

Parecem dois produtos incomparáveis dado o sentido da sua originalidade e da sua criação. E parece que, de fato, respondem a dois momentos históricos particulares, não só do México, mas da região. Não é a toa que essa obra de Rivera poderia se incluir na 
listagem dos seus últimos trabalhos, enquanto a cadeira de Hagerman é uma dos seus primeiros produtos.

Anastassakis me permite entender o núcleo do que poderia estar no coração do 'incomparável', se utilizo a premissa da sua reflexão acima do trabalho de Aloísio Magalhães e Lina Bo Bardi, quando comparadas com os modernos paulistas dos anos 1920. Para ela a diferença entre estes e aqueles, no relacionado com a cultura popular, era a conjunção de valores culturais e econômicos a favor dos primeiros (Anastassakis, 2014, p. 88). Para os modernos paulistas dos 1920, como para Rivera e tantos outros pela região toda, o valor cultural era o princípio e o fim da obra e a sua concepção. No entanto para Magalhaes, Bo Bardi, Hagerman e outros muitos por extensão, esse valor cultural estava ai sendo realçado, mas dialogava com os valores de cambio econômico, que já se impunham na sociedade.

Sem importar a diferença, me parece que a vocação segue a linha da procura daquilo que pode ser considerado como 'o nosso', de fato, quase se atualizando às condições que governam a sociedade nos anos 1970. Não importando se está se falando da consumada obra para a contemplação ou para sentar -no que esta de fato implicado um debate conhecido e complexo-, tanto o grande Rivera, quanto o enorme Hagerman, experimentam no fundo do originário e do popular para criar... já mencionei o que Renato Ortiz, pensando em Oswald de Andrade, diria: para ser modernos era necessário ser nacionais (García-Canclini, 2015).

3.

Agora, aqueles designers envolvidos no mercado profissional em seus países não fizeram apenas trabalhos nesse viés cultural. Os seus portfólios são diversos, exibindo produtos que vão de trabalhos pessoais ou individuais, passando por séries pequenas realidade da grande maioria dos seus clientes- até chegar nas produções de larga escala como eletrodomésticos e, em poucos casos, projetos de sistemas de transporte. Em todo caso, e em função do que pretendo mostrar aqui, um exercício exigido pelas condições e ao qual vários indivíduos sentiram-se convocados. Uma progressiva especialização do 'mercado profissional', que exigiu, na sua lógica e em contato com tensões provenientes de fora do amorfo campo, a complexificação do ofício e a posterior institucionalização.

A instalação e funcionamento de indústrias diversas e heterogêneas na região podem dar base a essa dinâmica. Desde o pioneirismo portenho e paulista como 
assinalado por vários dos historiadores da economia latino-americana, passando pelas diferentes instalações de indústrias de médio e grande porte que produziam respeitando a reprodução de patentes e o pagamento de regalias, até a instalação das multinacionais, supõem certo viés para o mercado profissional daqueles que trabalhavam com o que hoje chamaríamos 'desenvolvimento de produto' e também 'publicidade'. Nesse panorama, o capital privado e público aparecia misturado em determinados momentos.

Por exemplo, as exigências de empresas nacionais e estrangeiras como Philips, Noblex e Aurora na Argentina permitiram que Hugo Kogan, Roberto Napoli e Julio Colmenero -os dois últimos delegados fundadores da Argentina na ALADIacumulassem uma determinada experiência como designers de eletrodomésticos, mesmo que boa parte do seu trabalho consistisse na adequação de projetos para a reprodução para o mercado interno argentino dos anos 1960 e 1970. Em todo caso, cada um deles participaram no desenvolvimento de produtos próprios, produzidos e comercializados por suas respectivas empresas. Casos como, por exemplo, o rádio Giulia desenvolvido por Napoli para Noblex em 1975, o acendedor piezoelétrico Magiclick projetado por Hugo Kogan para Aurora em 1970 e o televisor Televa, projetado por Colmenero em 1975 (ver figura 5). Da mesma forma, e como claramente defendido por Blanco, vários dos produtos feitos por eles e outros tantos designers argentinos -e me atrevo a afirmar latino-americanos- simultaneamente ou até em antecedência do que os que eram projetados na Europa e nos Estados Unidos (Blanco, 2016a, p. 105 e ss). ${ }^{7}$

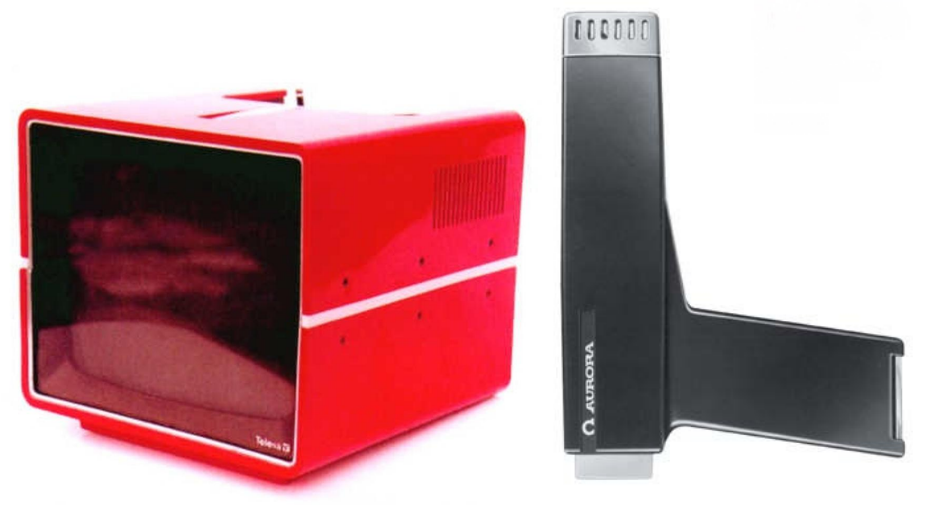

Figura 5a. Esquerda. Televisor Televa. Julio Colmenero, 1975. Fonte da imagem, Ricardo Blanco (2005). Direita. Acendedor Piezoeléctrico Magiclick. Hugo Kogan, 1970. Fonte da imagem, de José Rey (2009).

\footnotetext{
${ }^{7}$ Não digo que Blanco afirme tal coisa; a verdade me parece que não o faz explicitamente. Porém, tanto a contundência da comparação que faz naquelas páginas do seu livro, quanto -me atrevo interpretar- a ideia de fazê-las, parecem transitar na linha de demostrar simultaneidade e até antecedência na concepção de vários projetos argentinos em relação com famosos projetos da acrisolada história do design mundial.
} 


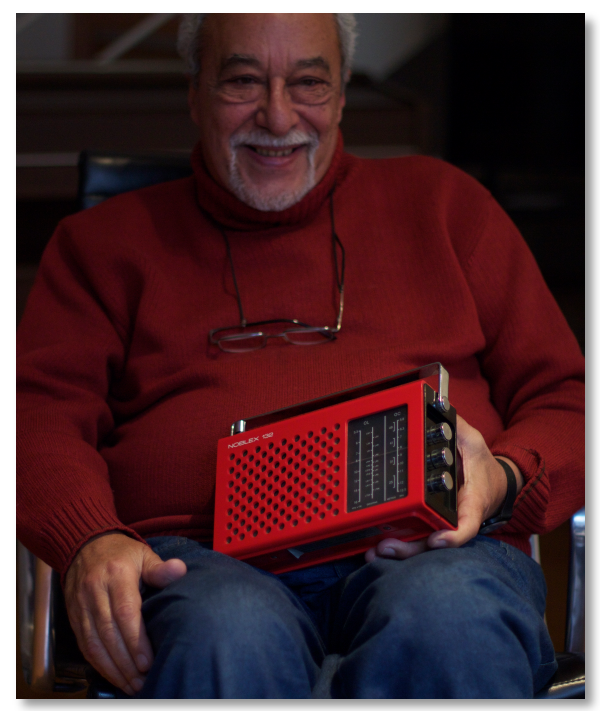

Figura 5b. Roberto Napoli posando com o radio Giulia da Noblex. Projeto 1975. Fotografia, Bibiana Peña, Buenos Aires, Argentina 2016 na casa do autor.

Também foi possível o design e o desenvolvimento de eletrodomésticos como geladeiras e fogões em vários dos países presentes na ALADI. Empresas como Siam Di Tella na Argentina, Consul no Brasil e Challenger na Colômbia -chamada INELSO-, estabeleceram linhas de desenvolvimento e produção com séries que cobriam o mercado interno e, em alguns casos determinados, até as demandas de países no exterior como por exemplo a brasileira Consul (Braga, 2014). Algumas ainda tiveram em sua estrutura interna setores com equipes que incluíam 'designers', no sentido mais geral.

Igual aconteceu com empresas de móveis que desde os anos 1950 oferecia a modernização do lar. Entre os envolvidos, artífices migrantes e experientes marceneiros atualizados, alguns deles com viés empresarial, assumem o desafio de projetar e produzir séries de objetos para o domicílio desenvolvendo principalmente móveis em madeira e, até mesmo, em metal iniciando a promoção do 'estilo de vida moderno' que era direcionado à crescente classe média latino-americana, como com sentido sociológico aponta Mina Hugerth no caso da Mobilinea em São Paulo (Hugerth, 2015).

Esse panorama incluía casos de economias mais robustas, o projeto de automóveis como ocorreu principalmente no Brasil, na Argentina e no México. O caso mais significativo parece ser o brasileiro, com vários projetos de pequenas séries e concurso de projetos especializados. A inércia e ímpeto dedicados a essa parcela da produção 
industrial podem explicar o projeto de um automóvel que foi produzido em larga escala para Volkswagen: o carro Brasília, por Martins e Piancastelli. ${ }^{8}$

4 .

Acompanhando esse processo de conformação do 'mercado profissional', vários dos envolvidos se viam, permanentemente, como participantes daquele novo ofício. 0 que é o que eu faço -com o passo do tempo chamado design-? O como poderia se definir o seu sentido e o seu lugar na sociedade? Entre muitas outras, essas perguntas transitavam nas reflexões de vários dos envolvidos no nascente ofício do designer. De forma mais ou menos esperada, esses raciocínios permitiram a construção de um discurso para a oferta de serviços e a conquista clientes -o dito sucesso no mercado- até o polimento dos limites jurisdicionais do amorfo campo e proteção da concorrência.

Dadas as suas experiências naqueles ofícios, é comum que vários deles acabassem envolvidos no mundo acadêmico. Disciplinas especializadas para cursos de arquitetura, palestras e cursos de curta duração, acompanhamento técnico, entre outras tantas facetas, aparecem na cena como possibilidade de desempenho simultâneo daqueles 'novos profissionais'. As apostas pelo desenvolvimento iam se ajustando ao passo das circunstâncias, parecendo cada vez mais importante o papel técnico-instrumental de um profissional com as habilidades dos chamados 'designers'.

Em seguida, delinearei o aparecimento do curioso interesse dos governos latinoamericanos em exigir e estimular o design em suas estratégias de desenvolvimento econômico nos anos 1970. Mas, por enquanto, é importante mencionar que esse interesse direcionou vários desses atores a se enfrentar à configuração de programas acadêmicos especializados. Tanto a experiência acumulada no ofício quanto as reflexões sobre o campo, foram fundamentais para responder à exigência. Posso pensar que foram momentos nos que as experiências adquiriram perspectiva enquanto os raciocínios eram disciplinados. É possível dizer que na América Latina a criação de programas acadêmicos e corpos associativos esteve estreitamente vinculada com o que Wrigth Mills (2003) chamou de "perspectiva do empírico" e não tanto ao transbordamento de conteúdos que descem por canudos predeterminados. Mais a frente aprofundarei.

\footnotetext{
${ }^{8} 0$ Brasil até projetou aviões naqueles anos -não sei se ainda o faz-. 0 avião Bandeirante ou o Ipanema são ícones da história da aviação no país luso-parlante.
} 
Dessa forma, são recorrentes as revistas especializadas desde os anos 1960 -a grande maioria delas, revistas de Arquitetura Moderna- nas quais se pode encontrar reflexões acerca da jurisdição e discricionalidade do ofício. 0 que é design? 0 que o diferencia de outras profissões como a arquitetura, as artes e a engenharia? Qual é a importância da sua existência? As perguntas iam ficando densas assim como os ensaios para resolvê-las, com clara evidência de uma permanência permanente -me aceitem a redundância- na cabeça dos envolvidos.

Tentando fugir de chauvinismos inúteis, me parece importante abrir um parênteses para mencionar de novo, que a diferença do ocorrido na Europa e nos Estados Unidos, aqueles que se sentaram para refletir sobre o exercício do design na região não tiveram ao seu alcance a estrutura de difusão que efetivamente tiveram europeus e norte-americanos desde 1960 com determinadas casas editoriais. Contudo, os latino-americanos que misturaram o exercício profissional do novo campo, o ensino acadêmico e mais à frente o trabalho associativo, com a reflexão e escrita para a promoção e difusão da disciplina, usaram em várias ocasiões aquelas revistas de Arquitetura Moderna e até mesmo os jornais de circulação nacional, para publicar seus textos. Esse tipo de texto pode ser encontrado em diversos meios de comunicação em Cuba, México, Colômbia, Argentina e Brasil e suponho que não seja diferente nos outros países da região.

Em todo caso -e fechando os parênteses- me parece necessário mencionar novamente o pioneirismo nesse exercício de reflexão de Clara Porset e Tomás Maldonado. Com relativas diferenças daqueles que mencionei anteriormente -entre outras coisas por ser filhos de gerações diferentes- a cubana e o argentino praticamente inauguraram esse exercício reflexivo em torno dos sentidos do design no final dos anos 1940.

Se o profissional-político parece ser o eixo em torno do qual giram as reflexões da geração dos 1960 e 1970, parece claro que para Porset e Maldonado o problema do design era um assunto estético-político. Com claras diferenças de ênfase e até de complexidade reflexiva, é compreensível que fossem assim. Levando em conta que Porset nasceu 27 anos antes de Maldonado, os dois, pertenceram a grande geração preocupada com as generalidades da mudança social que está instalada no coração da modernidade. Com as suas evidentes diferenças -algumas das quais assinalei anteriormente-, o pioneirismo de Porset e Maldonado direcionou ideias e crítica 
orientando com relativa contundência as definições da jurisdição e a discricionalidade do design nos seus países, na região e -efetivamente no caso de Maldonado- no mundo do design.

\section{Caixas de ressonância}

1.

Quero interromper momentaneamente o relato para abordar um principio importante. A gradual complexidade da vida social pode explicar a necessidade de aprofundamento em determinados campos e temas. De diferente forma, por exemplo as reflexões em torno das plantas e as suas propriedades curativas estabeleceram um ofício bastante diferenciado e especializado em determinadas sociedades, o seu conjunto e a complexidade de espécies botânicas e métodos de aproximação -ligadas às mudanças das formas de ver e sonhar a realidade- fizeram daquele ofício uma tarefa cada vez mais especializada, sendo necessários treinamentos cada vez mais compridos e esotéricos para dominar o ofício.

Pelo menos uma imagem se desenha na minha cabeça. Ainda sendo parte de uma narrativa de ficção, a descrição de Umberto Eco do trabalho e os desafios do botânico no Nome da Rosa, é uma imagem tintada de antropologia histórica (Eco, 1994). Das suas palavras é possível reconstruir determinados detalhes da vida de Severino da Sant Emmerano, o mítico botânico da abadia aonde ocorre a história. Aí, as concepções sobre a natureza, assim como as formas de se relacionar com ela caminham junto com formas como Severino procede em seu trabalho. Os esoterismos evidentes que ele controla como parte da sua ocupação fazem de seu ofício, nesse momento, um ofício altamente especializado. É tal o nível de conhecimento dos detalhes, que Guillermo de Baskerville personagem principal do romance- o consulta para resolver algumas das mais misteriosas inquietudes que observa no percurso da pesquisa em que está envolvido.

De mãos dadas com as mudanças sociais, esse ofício se torna mais complexo conforme passa o tempo, chegando em tal nível de especialização que as práticas de registro -que já tinham iniciado no momento de Severino-, os procedimentos e as diversas descobertas, demandam, não apenas mais pessoas interessadas naquele assunto, mas também que essas se dediquem a novas especialidades produzidas gradualmente. Dessa forma, o controle de toda a linha de conhecimento exige do artífice instrução e uma espécie de subdivisão do trabalho. Tanto especialização prática, quanto 
vocacional, agora exigem treinamento mais ou menos controlado, mais ou menos longo, mais ou menos custoso, como finalmente resultará na linha de profissionalização mais geral do conhecimento, como expõem, entre outros Greenwood e Wilensky (Greenwood, 1957; Wilensky, 1964).

Seria possível pensar para minha dissertação, que a descrição de Eco sobre o trabalho de Severino, é um antecedente do qual se desprende a especialidade moderna da botânica, por sua vez, o ramo especializado da biologia que se encarrega especificamente do estudo ' $\mathrm{x}$ ', por meio do uso das técnicas ' $\mathrm{y}$ ', para conseguir os objetivos sociais ' $z$ '. As densidades teóricas e os procedimentos, assim como o debate dos limites e objetos de estudo desse campo especializado, vão se ajustando e experimentando novas dimensões, cancelando velhas perspectivas e validando outras consideradas vigentes. Essa é a vida de uma profissão ocidental e, em grande parte, o que garante a sua existência social.

Analisando esse processo, vê-se que já não é unicamente na aprendizagem prática que aquela densidade é conseguida. Não é suficiente nem para Severino -o botânico de Eco- como também não para o artífice que transformava sensivelmente tal ou qual matéria. 0 ritmo social imposto pelo projeto moderno, faz com que muitas das destrezas que podiam ser aprendidas de forma espontânea e relativamente rápida, virassem esotéricas -abstratas demais- e parte do domínio de um grupo seleto. De tal forma que era preciso incluí-los dentro das instituições sociais que já destinavam o seu sentido social -assim como o seu tempo e os seus recursos- para o estudo e aprofundamento da disciplina. Dessa forma, alguns dos colégios medievais criados para o estudo permanente da ideologia oficial, viram paulatinamente universidades nas quais eram incluídos mais e mais objetos de estudo, no mesmo ritmo em que a sociedade vai se modernizando. Dessa forma, objetos como as ervas do Severino, entraram no catálogo das ciências modernas e significa um dos ramos da biologia que contribui para a economia neoliberal nas suas permanentes transformações e diálogos com a chamada indústria farmacêutica contemporânea.

Nesse processo de especialização é esperado que exista uma luta territorial. Penso em uma disciplina que se desdobra de uma mais velha. Parte da sua discricionalidade era praticada em um determinado momento por um campo profissional que considerava tais objetos de trabalho e estudo como uma das suas especialidades e derivações muitas vezes, menos importantes-. Por diferentes razões, essas práticas se adensam 
exigindo diferenciadas formas de proceder e até de pensar conduzindo ao processo. Isso vai puxando a autonomia dessa especialidade, rompendo com as suas heranças e emancipando o novo campo para convertê-lo em uma nova jurisdição. Essa emancipação é uma característica da modernidade. 0 processo não é necessariamente simples. Vários enfoques e atores do velho campo pretendiam governar aquele novo território, sendo que a ruptura estabelece uma tensão relativamente tradicionalista. Por sua conta -e embebidos em evidentes práticas maniqueístas- os defensores do novo território se auto-referenciarão como liberais, criando uma tensão oposta à tradicional. Essa briga pela legitimidade do campo, representaria uma das facetas mais caraterísticas dos seus desprendimentos, e as justificativas daquela emancipação a maioria das vezes não seria mais do que um discurso ideológico, em lugar de um raciocínio acerca das formas nas que aquele campo se presenta diante dos desafios sociais que lhe rodeia. Isso porque muitas vezes os atores parecem mais interessados na proteção da fragilidade do campo, que no seu próprio fortalecimento.

A luta pelo capital simbólico -com sentido sociológico como diria Bourdieu (2014) - caracteriza a relação daqueles atores nesse primeiro momento. Talvez por isso é frequente encontrar nos escritos dos que poderiam se considerar pioneiros do Design nos diferentes países da região, ideias relacionadas com diferenciá-lo conceitualmente da Arquitetura, das Artes ou da Engenharia, com uma relativa contundência do seu papel social. Sendo franco, o raciocínio parece automático na compreensão do Design como disciplina tecnológica -no momento em que se faz aquela homologação, as virtudes vistas acima da tecnologia são transpostas sobre o Design-.

Acima de abstrações que vão se clarificando e fortalecendo no passo do tempo, o treinamento ao ritmo das complexidades sociais e a luta pelo poder simbólico sobre aquela jurisdição se torna indicador da profissionalização moderna. Em conjunto direcionam o fortalecimento do campo no sentido mais geral. Cada um por sua vez ainda em diálogo permanente- direcionando processos institucionais que o respaldem e aos quais respaldar. Esse pode ser visto como a generalidade do processo de profissionalização acadêmica do Design na região.

2.

Nesse grande contexto, vários países da América Latina apostaram pelo desenvolvimento industrial e urbanístico como caminho para a conquista das promessas 
que trazia a modernidade e, fundamentalmente, como opção para superar a miséria e a pobreza que tanto inquietava a camadas de latino-americanos desde o tempo de colônia. A partir daí considerasse que fossem seguidas com relativo sucesso, planos e receitas principalmente para o meu argumento- após os anos 1940.

Nos anos 1960, os desafios e desajustes de determinados processos desenvolvimentistas forçaram ajustes permanentes naquelas apostas, fazendo com que as estratégias fossem reformuladas. Para mencionar um exemplo, a concepção inicial transparecia a ideia do desenvolvimento da indústria nacional por meio da substituição de importações. A grosso modo, se pensava que se as portas fossem fechadas para a entrada de mercadorias produzidas em países estrangeiros, os empreendimentos industriais nacionais teriam a oportunidade de criar e fortalecer as linhas de produção para o abastecimento do mercado nacional. Esse processo supunha implicações fundamentais no fortalecimento industrial.

Porém, diferentes causas ocorridas no percurso dos anos 1950, fazem com que a estratégia seja repensada. Por diferentes razões técnicas e até ideológicas, os promotores dessas teses chegaram na conclusão de que o modelo ISI -Industrialização por Substituição de Importações- deveria ser ajustado se tornando um modelo que promovesse a exportação de bens transformados. Mercadorias transformadas com alto valor agregado e que pudessem concorrer nos mercados internacionais, tentando ser colocadas como prioridade regional no sistema internacional de comércio, em lugar da exportação exclusiva de bens primários -café, banana, algodão, carne, minerais, etc.-. A proteção das fronteiras de determinados segmentos industriais continuava vigente inclusive até hoje em países como Brasil- mas a ilusão de exportar embriagava os planos.

Nesse cenário é explicável o intercâmbio de especialistas em diferentes áreas. Os diferentes tipos de acordos assinados entre agências de cooperação e governos da região, permitiam que missões inúmeras visitassem os países da América Latina durante aqueles anos. Muitas vezes, como no caso do Design para vários países da região, aquelas visitas propunham a formação de instituições desde a espontaneidade -como parece ser o casso da visita de Misha Black em São Paulo, quem estimula a ideia da criação de uma associação brasileira de design: ABDI (Braga, 2011)- ou por meio de sugestões por canais formais, como poderia ser o caso da chamada Missão Belga na Colômbia. Essa missão, chefiada por Jorge Gueben, propôs para PROEXPO -agência do 
governo colombiano para a promoção das exportações que contrata a missão-, que a maior universidade nacional do país configurasse o seu programa autônomo de ensino de Design Industrial e que seu corpo colegiado organizasse todos aqueles atores que configuravam nesse momento o campo profissional de design do país. Era um acordo assinado dentro da estratégia de estímulo à exportação de bens industrializados do governo colombiano.

Organizações internacionais como ICSID -International Council of Societies of Industrial Design- aparecem assim na cena reunindo especialistas e canalizando recursos para projetos de cooperação técnica. Nas suas memórias, Arthur Pulos membro fundador do Council e presidente entre 1979 e 1981- lembra como a postura do ICSID naqueles anos lhes permite ter projetos de assessoria em países tão diversos como afastados entre eles (Pulos, 1988). Desde a Argentina, passando pela Colômbia, o México e a Jamaica, até a Turquia, Indonésia e Índia, os designers europeus e norteamericanos filiados no ICSID nos anos 1960 e 1970, tiveram a missão de apoiar processos de promoção de exportações das mais distintas formas: ministrando cursos específicos de embalagens como no caso de Gui Bonsiepe na Argentina em 1963 ou assessorando pequenas unidades produtivas para a racionalização produtiva e a compreensão dos problemas do mercado internacional -principalmente o estadunidense-, assim como entrar em contato com instituições académicas para promover a configuração de cursos de design como no caso de Peter Müller na Turquia. ${ }^{9}$

3.

Esse fluxo explica tanto diálogos, iniciativas quanto relações pessoais entre sujeitos. Desde a famosa amizade entre os irmãos Sarabhai na Índia -eles fundadores do National Institute of Design em Amedabad (Eames \& Eames, 1997)- e o casal Eames, passando pela amizade entre Rómulo Polo e Alfred Girardy -que morou em Bogotá vários anos- ou na migração de Gui Bonsiepe para a Argentina. As comunhões permanentes e o compartilhamento formam densos e cálidos os vínculos e sobretudo,

\footnotetext{
${ }^{9}$ Não necessariamente dentro do ICSID, o designer suíço Alfred Girardy realiza um trabalho desse tipo na Colômbia durante a década dos anos 1960, fundando Artesanias de Colombia em 1964, assim como na, naquele momento, Formosa, alguns anos antes disso. Pelo sabido até o momento, parece que o seu trabalho teve apoio institucional e financeiro no que terminam envolvidos Corpos de Paz do governo Kennedy.
} 
tornam bidirecionais os mecanismos de ensino e aprendizagem de paradigmas, técnicas e propósitos.

As oportunidades apareceriam espontaneamente em meio às interações, como produtos de conversas. As razões e formas pelas quais Pietro Maria Bardi se relacionou com Assis Chateaubriand em São Paulo -por exemplo- explica a possibilidade de configuração de um dos institutos de ensino de design mas antigos na região: o IAC Instituto de Arte Contemporâneo- do Museu de Arte de São Paulo. Ali, resultaram envolvidos tanto os temas relacionados ao design como intelectuais importantes para essas reflexões, como Max Bill. Uma inquietude parte estético-política, parte acadêmicoprofissional, deu origem ao curso que durou apenas três anos mas que permitiu a formação como designer de personagens como Alexandre Wollner.

Considerando as devidas proporções, tanto em questão de conteúdo como em intensidade e nível de formação, esse tipo de curso foi simultaneamente promovido por instituições como -no caso do IAC- por museus de arte moderna que iniciavam as suas operações durante os anos 1950. O Museu de Arte Moderna -MAM- do Rio de Janeiro sediou um curso similar, assim como a Biblioteca Luís Angel Arango em Bogotá -mesmo que seu curso fosse mais focado em crítica artística-.

Os caminhos paralelos traçados foram tão diversos como inesperados nas linearidades da modernidade. Grupos religiosos, encarregados da administração de educação universitária, confeccionaram determinados cursos não formais a partir dos anos 1930, quase sempre destinados 'para senhoritas'. Aqueles cursos, configurando claros processos de profissionalização, se tornaram cada vez mais densos em abrangência, conteúdos e apostas conceituais. Em casos como o da Universidad Pontificia Bolivariana de Medellín, esse curso originalmente destinado a 'senhoritas' foi o antecedente da fundação do curso de design, cronologicamente o segundo do país, criado depois do curso de pós-grado que foi criado em Bogotá na Universidad Jorge Tadeo Lozano em 1972, e que virou graduação em 1974. Não conseguindo aprofundar, ao se dar uma olhada mais da região, é possível ver o pioneirismo de instituições de determinadas ordens católicas levando a bandeira na criação de cursos que por sua vez alimentaram a formação de cursos oficiais de design a partir dos anos 1960.

A Universidade Iberoamericana na Cidade do México é jesuíta, assim como a Universidad Javeriana de Bogotá e a Universidad Rafael Landívar na Cidade de Guatemala. As universidades pontifícias são localizadas em Medellín, São Paulo, Rio de 
Janeiro, Curitiba, Santiago de Chile, assim como a Universidade Presbiteriana Mackenzie em São Paulo, entre outras que seguramente escapam da minha contagem. De diferente forma, é possível comprovar que cada uma dessas instituições se relacionou com a ALADI. Algumas pretendendo ser representação institucional dentro da associação como é manifesto pelos guatemaltecos em Bogotá (Arroyave, L. et al., 1980)-, na grande maioria estimulando os seus professores e/ou alunos para participar nos diferentes eventos da associação.

4.

Parece-me importante abrir um novo parênteses antes de continuar. Mencionei no início deste capítulo que ao se pensar o início do processo de profissionalização do design, duas perversões aparecem. Tentarei ilustrá-las brevemente. É mais ou menos reiterado o interesse em desenhar uma linha reta que exiba o curso acadêmico de design mais antigo da região, como se estivesse relacionado com ganhar uma competência. Dependendo do país é usada alguma estratégia argumental específica para justificar a eleição de uma escola do seu território, como ganhadora do troféu, alimentando assim o mito de origem.

Um dos lugares comuns mais defendido no Brasil -por exemplo- é que a ESDI Escola Superior de Desenho Industrial- no Rio de Janeiro foi o primeiro curso de ensino de design do país, assim como da América Latina. Para negar a antecedência de qualquer outro curso criado na Argentina, no México ou até em Cuba ou na Colômbia -as duas últimas são agregadas por mim-, é enfatizado o fato de que ele foi o primeiro curso de nível 'superior', já que em nenhum desses outros países o ensino de Design iniciou nesse nível acadêmico, como sim ocorreu na emblemática escola carioca. Todas as vezes em que me encontrei com esse raciocínio, me perguntei qual o seu significado. Digo, o que significa nível superior? Mais que qualquer outra coisa, esse raciocínio está apoiado em um grande desconhecimento e evidentemente em uma gigantesca descontextualização. Por exemplo se defende naquelas glosas, que o caso mexicano não pode ser considerado como anterior a ESDI porque o curso promovido por Felipe Pardinas e iniciado por Jesús Virchez na Universidad Iberoamericana ainda fundado nos anos cinquenta, era técnico e não profissional. É mais ou menos claro o que isso significa hoje em relação aos processos de acreditação e intercâmbio internacional em que as instituições de educação superior vivem a sua agoniada cotidianidade. No entanto, impor essa categoria 
não só em um lugar geográfico quanto temporal diferente é, no mínimo, um disparate. Só para provocar uma reflexão mais densa desse assunto e dizendo que não estou interessado em construir ou contribuir nesse ranking, outorgo para os mexicanos o fato de que esse curso foi criado no interior de uma universidade configurada como tal -com faculdades e cursos diversos- enquanto a ESDI era em si um órgão dependente do Estado de Guanabara, do governador que a criou... um curso desconectado da institucionalidade acadêmica que supõe o conceito 'universitas'.

Considerar que o curso da 'Ibero' -como é chamada no México- não fosse profissional ou de nível superior -como se diz no Brasil- corresponde a uma formalidade e não uma questão fundamental. No México dos anos cinquenta, um curso podia ser considerado profissional sempre que também funcionasse na universidade nacional do país, a UNAM -Universidad Nacional Autónoma de México-. Se a UNAM tivesse tido um curso de design autônomo desde os anos cinquentas, o curso da Ibero simplesmente podia ser considerado profissional desde que começou e 1959. Pelo que consegui determinar, não só os conteúdos do curso de design da Ibero foram considerados naquele nível que chamaríamos 'de profissional' -preocupação que além de tudo não sei que tão latente estava na sociedade da época-, mas também alimentaram tanto o debate profissional do design mexicano dos anos sessentas, quanto a conformação dos diferentes cursos de design, como o da UNAM em 1968-1969. Dessa forma o nível que o curso teve, resulta evidentemente relativo.

A mim me parece que, hoje, essas expectativas estão na mesa por questões -digo novamente- de acreditação e de globalização educativa e, como exigência contemporânea, ela não pode ser trasladada sem pensar que se deformarão os fatos. Vários produtos daqueles cursos de design, deixam ver que o resultado na formação de Iberos e Esdianos estavam praticamente no mesmo nível. Os primeiros formados dos cursos, participaram ativamente na complexificação da profissão, se envolveram em projetos importantes para os seus contextos -por exemplo a base do grupo das olimpíadas na Cidade do México de 1968 foi da Ibero- e aprofundaram tanto o mercado profissional mexicano como o brasileiro. Acredito que a inocência que respira em baixo desse esforço, passa por alto que os processos ocorridos em países tão diversos e complexos são diferentes. O grave, para a compreensão da questão, é que acabam alimentando as miradas verticais entre grupos sociais -uma latente segregação- e, quem 
sabe, até nutrindo aquela característica que Francisco Weffort (1995) assinala sobre a região entrando no século 21: uma América Latina errada.

Fechando o parêntese, me parece possível propor uma estrutura geral de criação de cursos de design na América Latina, sob o feitiço da ideia de ciclo. Digo que me parece possível porque olhando a criação de cursos de design como conjunto, é mais ou menos fácil ver grupos concretos reunidos no tempo. Contudo, unidos em um grupo perdem a sua particularidade, homologando grosseiramente os processos (a 'mostra' é tão pequena que falar em dados agregados é, até mesmo, metodologicamente impertinente). Atrevo-me a propor a divisão por um assunto estritamente didático na minha explanação, renunciando às pretensões de ser concludente ou irrefutável.

Com diferentes motivações, interesses, estruturas e durações, desde o início dos anos 1950 aparecem alguns cursos de design na região. Uns mais formais ou institucionais que outros, dando boas-vindas ao treinamento daquele saber esotérico que ainda não se compreendia exatamente bem. Desde a criação do IAC do Museu de Arte de São Paulo em 1951-mencionado anteriormente-, criado por Lina Bo Bardi e Pietro Bardi, a criação da Escuela de Diseño y Artesanias, por Carlos Lazo em 1952 no Instituto Nacional de Bellas Artes do México, passando pelos cursos breves em museus de arte moderna, bibliotecas, instituições promotoras de cultura, até a mudança das grades curriculares de programas de arquitetura para incluir o Design -como os cursos de arquitetura da Universidade de São Paulo ou da Universidad Nacional de Colombia-; assim como a criação de cursos em instituições governamentais como a iniciativa do governador do Estado de Guanabara -hoje Rio de Janeiro-, que decide dar forma à famosa ESDI.

Nesse primeiro ciclo, algumas universidades de forma mais ou menos isolada somam-se ao processo criando cursos autônomos. As mais notórias foram a Universidad Iberoamericana no México em 1959 (Ramírez, P. et al., 1980) e as Universidades Nacionais de Cuyo e de La Plata na Argentina. O primeiro caso em 1958, o segundo em 1963 (Devalle, 2009). Esse seria o primeiro ciclo para mim. Multe-institucional, de diferentes níveis de vocação e, algumas vezes, não respondendo estrategicamente a um plano maior.

O segundo iniciaria em 1969 com a conformação do curso de Diseño Industrial na Universidad Nacional Autónoma de México -UNAM-, a cargo de Horacio Durán. Esse ano se inaugura um ciclo que dará origem à mais variada gama de cursos de design, 
estabelecidos, em sua grande maioria em instituições universitárias dos países da região, de forma consecutiva e aparentemente interessada na produção de mercadorias de qualidade. Esse ciclo termina dez anos depois, com a criação do curso de Diseño Industrial no Instituto Tecnológico de Costa Rica em Cartago, a cargo de Franca Rosi e Oscar Pamio (Rosi, 2016).

Ainda remotamente, o nascimento da ALADI esteve relacionado com aquela primeira onda de criação de cursos na região, os cursos que iniciaram no final dos anos 1950. E ainda mais estreitamente relacionado com o segundo ciclo que começa em 1969. Vários dos fundadores da ALADI se formaram nesses cursos ou fizeram parte dos processos de suas configurações. Se o primeiro ciclo foi relativamente difuso em relação ao debate da jurisdição e discricionalidade da profissão, o segundo inaugurou uma rica discussão sobre essas questões, contribuindo naquele processo de 'perspectiva da experiência' no campo, que abordei no subtítulo anterior.

\section{Sem querer querendo?}

1.

Os processos de profissionalização de um ofício são mais ou menos 'finalizados' no momento em que são criados mecanismos institucionais por meio dos quais sejam estudadas as abstrações conceituais e ideológicas do campo assim como treinadas as suas práticas discricionais. Nesse momento os profissionais dessa ocupação iniciam uma tensa relação com a sociedade na qual vivem. Se os processos de profissionalização acadêmica resultantes na configuração de cursos e treinamentos longos e custosos parafraseando Wilensky (1964)- iluminam o papel social que a profissão tem como "chamado secular" -a expressão é de Weber dentro dos raciocínios de Freidson (2001)-, a criação de corpos colegiados que reúnam os profissionais da área, permitem uma relação frontal com a sociedade.

Essa relação frontal é vista como um baluarte dos processos de profissionalização por vários dos teóricos das profissões, dado que -para o expor brevemente- ela apresenta uma tensão que se relaciona com princípios fundamentais da democracia e o equilíbrio do poder. Na primeira dimensão, principalmente trabalhada por Talcot Parsons (1979), se defende que o esoterismo do saber profissional -o saber profissional é por princípio inatingível pelo sentido comum-, se torna acessível para as pessoas no momento em que vira útil para um indivíduo na sua cotidianidade. E dizer, na 
necessidade de resolver um problema ordinário -por exemplo relacionado com a lei- o advogado -dono do saber abstrato- coloca nas mãos do necessitado as maneiras de resolver o impasse, sem que esse tenha que chegar nas cumes da abstrações da advocacia. Ainda considero ilustrativo o raciocínio de Parsons, sempre tinha o percebido como romântico-. Nos seus raciocínios não parece ter lugar para a imperfeição do sistema, como tampouco dos atores apaixonados. Em todo caso -insisto- me parece ilustrativo para o que estou tratando.

Naquilo que está relacionado com equilíbrio do poder, Freidson (2001) -também com análises relativamente abstratas, ainda muito mais ilustrativas e desenvolvidas que as de Parsons- afirma que o Profissionalismo é uma lógica, de tal tamanho, força e autonomia, que concorre com a lógica do Mercado e a lógica do Estado. Grosso modo, Freidson afirma que as abstrações dos saberes profissionais, como por isso as dinâmicas de auto-definição de jurisdições e discricionalidades -isso último mais das ideias de Andrew Abbott (1988)- lhe permite aos profissionais organizados, um determinado tipo de autonomia e de pressão. Autonomia no sentido de definir internamente os seus limites, o seu papel e funções na realidade social e econômica. Pressão na possibilidade de impactar tanto a sociedade nas abstrações do seu saber, quanto de sensibilizar permanentemente tanto o sistema político que regula a sociedade, como o mercado que a fornece

[...] El profesionalismo, en tanto que discurso, es un poderoso instrumento de cambio y control ocupacional en el mundo moderno [...] construído y controlado por diferentes grupos ocupaciones. Julia Evetts em Buitrago (2012, p. 38).

Nesse cenário -e como talvez já pareça óbvio- a configuração de corpos colegiados e associações permite pensar que além da recriação do prestígio -que também está presente na questão- tal estrutura institucional cria um cenário para que todos aqueles processos tenham lugar. Desde o espaço para a determinação dos limites e objetos de impacto profissional, passando pelas táticas de representação dos colegas, até chegar às estratégias de relação com os governos e os mercados que compõem a sociedade em que se desempenham. Claramente, uma concepção ocidental, capitalista, altamente relacionada com o "modernismo fordista" que explora Harvey (2014). Em um capítulo posterior aprofundarei algumas das análises de Harvey, mas por enquanto me parece importante dizer, que essa "meta-teoria", como seguramente Harvey chamaria o trabalho de Freidson, parece organizar as expectativas de desempenho em uma época 
particular da modernidade. Não entendo que essas certezas possam ser identificadas na generalidade do Ocidente após 1973, ou na particularidade da América Latina após a “década perdida”... os anos 1980.

Parece-me -e isso deve ser aprofundado em outro trabalho- que o formato associativo corresponde às expectativas dessa a época e parecem ter se asfixiado gradualmente a partir da metade dos anos 1970. Os anos 1980 são anos dúbios e a década dos anos 1990 se parece mais com uma transição para 'algo novo', do que com o retomar do rumo anteriormente trilhado. Um rumo que as crises do capitalismo dos anos 1970 evaporou.

2.

$\mathrm{Na}$ sua tentativa de implementar as receitas do desenvolvimento e a modernização, vários dos governos da América Latina estimularam indiretamente a institucionalização do design. Com os seus respectivos antecedentes, é possível detectar instituições nacionais que procuraram o desenvolvimento industrial, dentro do qual, o design apareceu como uma das linhas de investimento. Um desses casos poderia ser a “Divisão de Desenho Industrial" no Instituto Nacional de Tecnologia -INT- criado no governo militar de Ernesto Geisel no Brasil. Desde o desenvolvimento de energia nuclear e passando pela pesquisa marítima -entre outras-, esse plano inicial contemplou o Design Industrial como uma das 19 linhas de trabalho. 0 instituto iria apoiar o desenvolvimento do país, a partir do trabalho estratégico naquelas áreas e a Divisão estaria a cargo do relacionado com o design, uma das suas áreas privilegiadas.

Não consegui estabelecer de onde proveem a 'lucidez' de incluir o Design dentro do plano, especialmente pela particularidade com a qual trata-se, considerando-o no mesmo nível de importância de áreas tão diretamente relacionadas com o desenvolvimento tecnológico

[...] Luiz Blank: 006 é somente um desses programas que até hoje [...] quem escreveu o programa mesmo, morreu e ninguém realmente chegou para ele e perguntou, vem cá, por que é que você botou Desenho Industrial aí?

Juan Buitrago: Essa é um pergunta que eu queria fazer.

LB: Não, não, não procure saber [risos] 006 é um programa do governo. A única coisa que a gente especula que pode ser é que o Costa -era o cara que escreveu-, tinha morado ou morava nessa época, na Áustria, 
em Viena [...] seguramente, Desenho Industrial para ele era uma coisa comum, né? Ele morava embebido já há muito tempo na cultura [...] Então, quando ele volta para o Brasil e ele veio para escrever... escreve essa proposta onde tem 19 programas. Todos de engenharia, menos o 06. Se você olhar todos, nenhum tem a ver com design [...] é tudo engenharia pesada. Engenharia de ponta.

JB: E ele trabalhava no governo? Ele era funcionário?

LB: Ele foi convidado para ser secretário de Tecnologia Industrial. Correia da Costa. Luiz... Luiz Fernando, eu acho. Eu sei que é Luiz Correia da Costa. Eu cheguei a conhecê-lo, assim, de vista (Blank, 2014). ${ }^{10}$

O chefe daquela Divisão foi o engenheiro paulista Itiro Iida, importante personagem na história da institucionalização do design brasileiro. Segundo a minha conversa com Luiz Blank, Iida foi responsável pelo estimulo de vários processos de fortalecimento do design. Foi ele que, por exemplo, estabeleceu o vínculo com Gui Bonsiepe, que estava radicado na Argentina nesse momento -meados dos anos 1970-. Por conta da fama que já começava rodear o trabalho do alemão e a relativa proximidade com as ideias de Iida, Iida pede a Luiz Blank que entre em contato com Bonsiepe em uma viagem que fez a Buenos Aires, com o intuito de o convidar para viajar para o Brasil como assessor na área (Blank, 2014). Daí para a frente, já é conhecida a participação de Bonsiepe na institucionalização do design brasileiro.

No intuito de fortalecer a presença do design no Ministério de Industria e Comércio -aonde estava sediado o INT- e, a partir daí, se projetar em assistência e acompanhamento para a indústria, a Divisão assumiu as tarefas de analisar e acompanhar projetos da Secretaria de Tecnologia, mudando várias vezes de rumo por causa de oscilações governamentais relativas à ciência e tecnologia (Leon, 2005). Junto com Blank, naquele "Departamento de design" do INT estiveram envolvidos José Abramovitz e Anamaria de Morais -também designers da ESDI-. Sendo esses dois dos brasileiros ativamente envolvidos na movimentação institucional de design dos finais dos anos 1970 e, efetivamente no processo de criação da ALADI desde 1978.11

Um outro instituto levará a mesma raiz de nome ao parecer de forma coincidente. Em Buenos Aires vários anos antes do estabelecimento do instituto brasileiro, o governo

\footnotetext{
10 Marcos Braga especifica que o nome do secretario é realmente Luiz Correia da Silva. Da mesma forma, ele também aponta que o plano aonde termina incluído o Design foi o Plano Básico de Desenvolvimento Científico e Tecnológico, PBDCT 1973-1974.

${ }^{11}$ Leon (2005) agrega a Maria Isabel Ferraz Rodriguez e Diva Maria Pires Gonçalves.
} 
constitui o INTI como instituto de fomento e fortalecimento da tecnologia para a indústria

[...] El 27 de diciembre de 1957, el Poder Ejecutivo bajo la Presidencia del general Pedro E. Aramburu, considerando que es función del Ministerio de Comercio e Industria la asistencia tecnológica a la industria, decide crear por Decreto Ley 17138/57 el Instituto Nacional de Tecnología Industrial, con el fin de promover la investigación industrial técnico científica, a través de una acción conjunta, estatal y privada, acorde con las necessidades reales de la industria (Rey, 2009, p. 17).

Desde cedo -quem sabe se desde o princípio- foi o engenheiro Basílio Uribe o encarregado de chefiar a sua promoção. Foi precisamente ele quem estimulou a criação do CIDI -Centro de Investigaciones de Diseño Industrial-, uma espécie de departamento especializado do INTI, que inicialmente pretendia ser um lugar para se debater o design -como propósito abstrato- assim como -principalmente- realizar uma exposição internacional de design industrial, como afirma Rey (2009). O plano de trabalho do CIDI no seu primeiro ano (1963) pretendia a abstração de difundir a ideia da importância do design industrial para a indústria, o comércio e a cultura, principalmente, no acesso a mercados externos, fazendo eco à mudança do modelo de industrialização -do pregoado ISI à promoção das exportações de bens industrializados-. Abordava os seguintes pontos:

[...] 1) Realizar una Exposición Internacional de Diseño Industrial; 2) Dictar Seminarios de alto nível sobre el tema; 3) Organizar un Concurso Permanente de Diseño Industrial; 4) Organizar una Muestra Permanente de Diseño Industrial; 5) Estudiar la posibilidad de crear un Museo de Diseño Industrial; 6) Estudiar la posibilidad de crear un Instituto de Enseñanza del Diseño Industrial; 7) Realizar actos de difusión; 8) Solicitar su incorporación como membro activo al ICSID (Rey, 2009, p. 26).

Propósitos claramente focados na difusão e promoção da disciplina, com a clara a ideia de estimular o Design Industrial pelas virtudes que alguns pareciam ver no seu esoterismo vocacional. Os engenheiros -principalmente Basílio Uribe e Pablo Tedeschie, sobre tudo, os arquitetos envolvidos -especialmente Rodolfo Möller e César Janello- já consideravam que o design era um caminho certo para promover determinados processos, como o desenvolvimento tecnológico e a satisfação de necessidades dos usuários: "el estúdio y la enseñanza del diseño tecnológico [como deliberadamente chamaram o Design Industrial] contribuyen a la preservación de las condiciones de una 
vida verdaderamente humana en un mundo governado por la técnica." Trecho da proposta para a criação de um Departamento de Diseño Tecnológico na Universidad de Buenos Aires em 1960 (Rey, 2009, p. 19).

Essa proposta foi acompanhada -complementada- pela causa educacional numeral 2 e 6 dos pontos de trabalho- e pela menção do interesse por participar do ICSID. É evidente que esses três pontos gravitavam em torno da proposta, como fortalecendo-a. Mais a frente abordarei alguns deslocamentos dessa aposta argentina.

O CIDI estimulou, divulgou e acompanhou processos importantes de projeto de eletrodomésticos, automóveis, etc., deixando um catálogo de 1800 peças selecionadas para as suas mostras entre 1963 e 1974, ano em que finalizou a sua primeira etapa.

A figura de Uribe é importante nesse contexto, principalmente por duas razões. A primeira, a sua participação na profissionalização do design na Argentina. Durante os anos sessenta -e aparentemente ligado às discussões dentro do ICSID em torno das suas nascentes preocupações com o ensino do design e o seu papel nas economias em vias de desenvolvimento- Uribe e outros como Rodolfo Möller, estimularam um diálogo direto com as preocupações em torno do ensino do Design Industrial nos países em desenvolvimento. Em processos relacionados com o ICSID e UNESCO, personagens como Uribe, Möller, Maldonado e Bonsiepe, apareciam na cena articulando a institucionalização acadêmica na Argentina de meados dos anos 1960. Sobra mencionar a importância de Maldonado nesse vínculo. Entre várias coisas, Uribe participou em eventos como a reunião de 1965 na $H f G$ de Ulm (ICSID Conference) mencionada por Spitz (2002), assim como na organização do Seminário Internacional para a "Enseñanza del Diseño Industrial en los Países Latinoamericanos", segundo Möller organizado por Uribe por petição do ICSID. ${ }^{12}$ Nele trabalharam em parceria o ICSID e o INTI, convocando uma plêiade de promotores do design nos diversos países da região e do núcleo duro do ICSID

[...] A las intensas reuniones de trabajo preparadas para esos días, concurren como panelistas algunos de los más renombrados expertos y maestros Internacionales: Misha Black, Director de la Escuela de Diseño Industrial del Royal Collegue of Arts de Londres; Arthur Pulos, Decano de la Escuela de Diseño Industrial de la Universidad de Syracuse, EE.UU.;

\footnotetext{
12 Segundo o seguimento que Rey (2009) faz dos comunicados do ICSID que chegam no CIDI, tanto o seminário ao que assiste Uribe em Ulm em 1965, quanto aquele que organiza em Buenos Aires em 1968, estão inseridos em uma sequência de eventos sobre o ensino mundial do design. 0 primeiro foi organizado em Syracusse University nos Estados Unidos, o segundo em Bruxas na Bélgica, o terceiro em Ulm e o quarto em Buenos Aires.
} 
Ilmari Tapiovara. Presidente del Ornamo, de Finlandia; Roger Tallon, máximo diseñador francés: Tomás Maldonado, presidenle del ICSID; Josine des Cressonnières, secretaria del ICSID, Jorge Vila Ortíz, en representación del IDI de Rosário; Alexandre Wollner, Director de la Escuela de Diseño de Rio de Janeiro; Glauco Casanova, diseñador uruguayo, representantes del CIDI, y observadores de las Facultades de Ingeniería y Arquitectura de Buenos Aires y de Chile, Perú y Colombia (Möller, 1969, p. 25).

Acompanhando esse ativismo de Uribe em torno da difusão e promoção do Design Industrial na Argentina e as suas ações de vínculo com debates acirrados de nível internacional, uma segunda razão importante para o meu argumento é a sua presença em duas das reuniões precedentes à configuração da ALADI em Bogotá em 1980. Sua primeira participação se deu no famoso encontro celebrado realizado na Índia em janeiro de 1979, para tratar a questão do Design nos países subdesenvolvidos. Como aprofundarei mais a frente, foi nesse evento organizado pelo ICSID que José Abramovitz do Brasil -participante em representação do INT brasileiro-, Rómulo Polo da Colômbiaquem representa a Universidad Javeriana de Bogotá- e Basílio Uribe pela Argentina CIDI- se conheceram. Esses três latino-americanos, na companhia de Gui Bonsiepe, assinaram um documento que pretendia continuar a iniciativa de criação de uma organização regional de design, proposta inicialmente dois meses antes em Valle de Bravo, no México. Pelo sabido, Uribe sensibilizou os seus compatriotas com a ideia de formar ALADI e a necessidade de aproveitar o vindouro congresso do ICSID, que seria celebrado na Cidade do México em outubro desse ano (1979).

Foi precisamente nesse congresso que Uribe teve a sua segunda participação. Mais a frente apresentarei alguns detalhes, mas foi aí, aproveitando a celebração de um congresso do tamanho e a proporção do que foi feito naquela ocasião no México, que vários latino-americanos envolvidos com assuntos da institucionalização do design nos seus países, sentiram-se convocados para assistir. Entre várias coisas, no marco daquele congresso foi assinado o maior documento de intenção de criação da ALADI, por 66 pessoas provenientes de mais de 8 países... foi concretizado o "pacto das catacumbas". Nesse momento também foi fixado o cronograma de fundação e entregue a tarefa para a Colômbia, que convocaria, um ano depois -novembro de 1980-, a primeira assembleia e o primeiro congresso da ALADI. 
3.

Aquele 'perfil' das instituições que estimulavam o design -que poderia chamar de instituições de fomento do desenvolvimento tecnológico- estava associado a um outro tipo de instituição. Também governamental, em parte seguindo as receitas para o desenvolvimento e a modernização, em parte por iniciativas internas, as que chamo 'instituições de promoção das exportações' também estimularam o nascimento e fortalecimento do design em vários países da América Latina. ${ }^{13}$

Se a Argentina e o Brasil pareciam compartilhar o viés tecnológico do desenvolvimento, a Colômbia e o México se assemelhavam ao percorrerem mais ou menos o mesmo caminho, afastados do núcleo embasado na tecnologia -ao menos no que diz respeito aos personagens envolvidos com a criação da ALADI-.

A perda de força do desenvolvimento vivido pelos países latino-americanos durante os anos cinquenta -sobre tudo a sua segunda metade- faz com que a estratégia de substituição de importações para a industrialização seja revisada nos seus detalhes. Uma das cartas mais plausíveis foi considerar que ao se produzir produtos para mercados externos e não só para os mercados internos -como estava inicialmente planejado-, a industrialização seria puxada -como desejado desde ISI-, com um relativo melhoramento dos problemas que já tinha engendrado a prática do modelo. Entre o que se considerou estratégico para conseguí-lo, estavam aqueles produtos de alto valor agregado, com séries curtas, e que deveriam ser atualizadas nos pormenores da comercialização internacional como garantia do fortalecimento das balanças de pagamentos.

Nesse marco o governo mexicano organizou o Centro de Diseño dentro do Instituto Mexicano de Comercio Exterior -IMCE-, que tinha como propósito assessorar no melhoramento de produtos assim como o desenvolvimento de embalagens para mercados exteriores. Esse Centro de Diseño era composto por várias linhas de desenvolvimento de produtos, entre as quais estavam o assessoramento artesanal, embalagens, projeto de stands, entre outros segundo lembra Claudio Rodríguez, membro do Centro e fundador da ALADI (Rodríguez, C., 2016a; 2016b).

\footnotetext{
13 Sei que o CIDI argentino é uma entidade mista que combina presencia privada e oficial. Contudo, tanto a iniciativa como o orçamento de determinados processos provêem do Estado, típica ação das matrizes estado-centricas da época.
} 


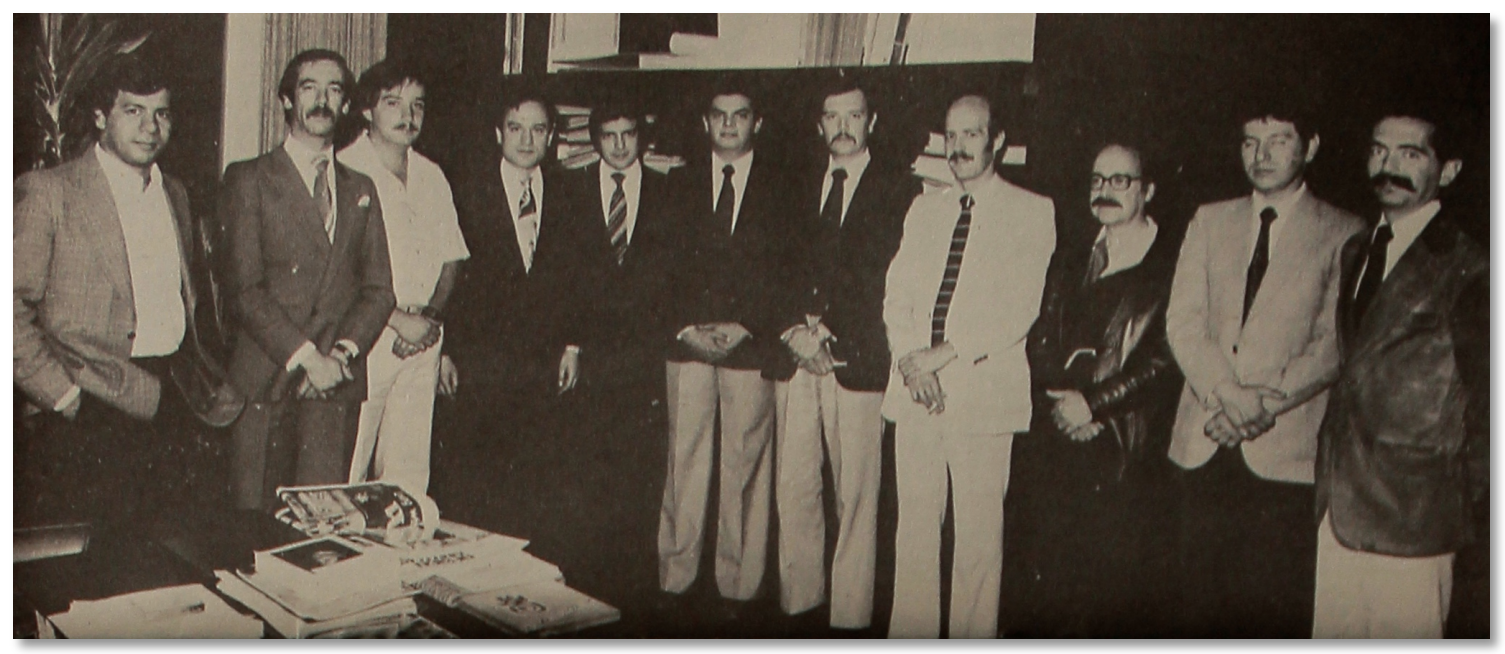

Figura 6. Membros do Patronato Nacional de las Asociaciones de Diseño A.C. no México.

Vários dos fotografados faziam parte do IMCE durante os anos 1970. De esquerda a direita: Oscar Salinas, Claudio Rodríguez, Francisco Montaño, Alejandro Lazo, Manuel Lugo, Sergio Rivera, Héctor Sánchez, Manuel Alvarez,

Francisco García, Pedro Icaza e Fay Medina (Lazo, A. et al, 1980). Acervo Pessoal Oscar Salinas, Cidade do México (APOS).

É possível afirmar que aqui jaz a base do Comité Nacional de ALADI - México. No mínimo Salinas, Rodríguez, Lazo e Rivera participam ativamente na ALADI.

O IMCE articulou e estimulou várias atividades em torno do design: promoveu concursos, exposições e -talvez a mais visível de todas as ações institucionais- concebeu a ideia e assumiu o compromisso na Irlanda de organizar o 11ํㅡㄹ Congresso do ICSID na Cidade do México em 1979, em sua primeira e última edição realizada na América Latina. Como mencionei, esse congresso foi fundamental para explicar a potência que adquiriu a ideia de criação da ALADI. Nele teve lugar o que eu chamo de "o pacto das catacumbas"; mais a frente aprofundarei.
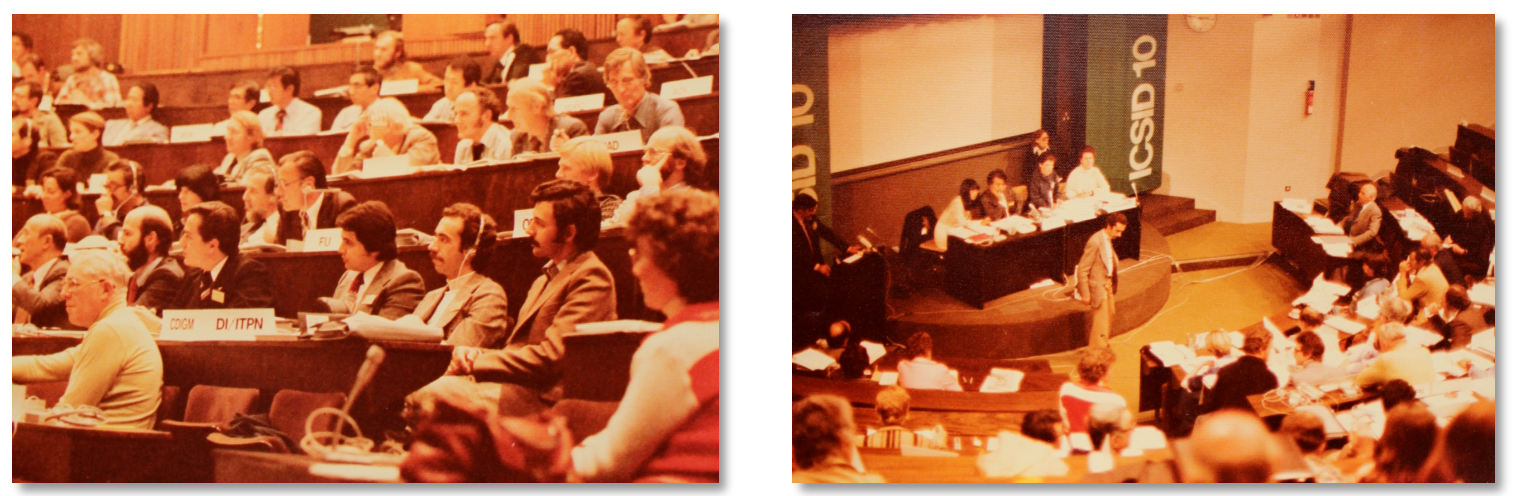

Figura 7. 10ํㅡㄹ Congresso do ICSID em Dublin em 1977.

Esquerda, no centro da imagem a delegação mexicana (do DI ITPN), direita, apresentação da Cidade do México como sede do seguinte congresso. Acervo pessoal de Claudio Rodríguez na Cidade do México (APCR). 
Por enquanto menciono ainda, que nesse momento, a Colômbia recebeu a visita de uma missão de especialistas em produção artesanal incumbidas de organizar aqueles processos nas regiões por onde passavam. Organizar no sentido de estudá-las para sugerir mudanças nas formas de trabalho -quase sempre com o propósito de 'serializar' a produção- e treinar os artífices quanto aos princípios de comercialização internacional. Essas tarefas estavam acompanhadas do empenho por entrar em contato e sensibilizar instituições educativas, para que iniciassem a criação de programas de design.

Sendo sincero, ainda não consegui determinar se essas tarefas eram parte da missão na qual chega Alfred Girardy a Bogotá. Atrevo-me a pensar que assim o foi, pautado nas descrições de Pulos no interior do ICSID para outros tantos casos. Segundo ele, durante aqueles anos -desde 1955 e durante os anos 1960- vários missionários do ICSID foram incumbidos dessas tarefas em diferentes países do mundo, entre os quais esteve a Colômbia, o México, a Jamaica, a Argentina, a Turquia, a Indonésia, etc., sobretudo quando o ICSID trabalhou em parceria com o Departamento de Estado dos Estados Unidos, o ICA, finalmente chamado USAid (Pulos, 1988). Ainda parece que Girardy não esteve incluído naqueles projetos do ICSID, não é difícil inferir que ele tenha realizado aquelas três tarefas. Isso é visível em duas grandes contribuições para a profissionalização do design na Colômbia: por uma parte o estabelecimento do contato com a Universidad Javeriana de Bogotá, aonde ministrou uma série de cursos de Diseño Básico entre 1967 e 1968, deixando a base para a formulação do programa profissional de Design Industrial, que ocorrerou em 1976, graças ao trabalho de Rómulo Polo, praticamente sugerido por Girardy para esse trabalho (Polo, 2014a).

Em segunda instância, Girardy propôs a criação de Artesanias de Colombia, uma agência do governo colombiano que se dedica à organização dos artífices nas suas regiões, com o propósito de acompanhá-los na produção e a comercialização dos seus produtos. Artesanias de Colombia foi criada em 1964 e em 1966 já tinha organizado um Departamento de Diseño para acompanhar aqueles processos. Até 1968, sua direção esteve nas mãos de William Newman, jovem designer norte-americano que trabalhou em Bogotá como missionário dos Corpos de Paz do governo estadunidense. Polo foi o primeiro colombiano a orientar esse departamento, no final da década.

Poucos anos mais tarde, uma outra agência governamental impulsionou a institucionalização do design colombiano. Complementando o sugerido espírito 
exportador de Artesanias de Colombia, o governo de Misael Pastrana criou a PROEXPO, agência focada no estímulo para exportação -principalmente naquele momento- de bens transformados. É ela que vai contratar algumas outras missões de assessoramento internacional como a mencionada "Missão Belga". A missão afirmou duas coisas importantes para o processo: a primeira, que já era hora de que a maior universidade pública do país formalizasse o seu curso de Design Industrial -para 1976, ano da missão, a Universidad Nacional completava 10 anos com sequencias de design industrial para arquitetos- e a segunda, a sugestão para que a PROEXPO reunisse os profissionais de design e estimulasse a sua organização gremial

[...] La misón belga que había venido al país patrocinada por Proexpo, el gobierno belga y el ICSID [...] Ella [Jossine de Cressonniere -ICSID-] de acuerdo con los objetivos de la misión, fue a Artesanías de Colombia y le dijo a Graciela [chefe do departamento daquele momento] que desde esta empresa era que tenía que nacer un movimento importante de diseño para Colombia. Jairo Acero (Quiñonez, C., \& Barrera, G., 2006, p. 133).

4.

Os menciono por serem meus casos mais documentados. Contudo, projetos de cooperação internacional estavam envolvidos nesses tópicos durante os anos setenta, trazendo arquitetos e designers para assessorar processos nos diferentes países da região. Muitas vezes eles vieram por intermédio do ICSID, outras vezes por meio de outras agências, convênios, caminhos e vias. Um dos mais interessantes -estritamente ligado com ALADI- foi o projeto de cooperação assinado entre o governo da Costa Rica e o Istituto per la Cooperazione Universitaria -ICU-, que permitiu que Franca Rosi e Oscar Pamio chegassem a Cartago para ministrar algumas aulas técnicas de construção. Com o passar do tempo, outras necessidades expressadas no país centro-americano favoreceram a criação do primeiro curso de design naquele país em 1979 no Instituto Tecnológico de Costa Rica pelo casal italiano. Nesse momento, eles conformaram a primeira associação de designers do país. 0 local se tornou emblemático. Acompanhando um e outro processo, o Instituto editou uma das publicações especializadas mais importantes e paradoxalmente mais desconhecidas de design latinoamericano desde 1979, a Revista Módulo.

Por outro lado, transitando o seu próprio caminho, estava a ONDI -Oficina Nacional de Diseño Industrial- formada pelo governo cubano. Essa instituição herdou linhas institucionais que se iniciam praticamente com a Revolução, como pode-se ver 
nos relatos de Lucila Fernández (2005; 2012). Segundo levantado por ela, a profissionalização do design cubano estava avançando desde 1960. Ações iniciadas a partir das preocupações da Revolução com o fornecimento de mobiliários de hospitais, moradias, praias públicas e centros de lazer, justificam a criação do Departamento de Muebles de la Dirección de Arquitectura do Ministério da Construção (MICONS) que foi orientado pelo arquiteto Antonio Quintana (Fernández L. , 2012, p. 9), passando pela iniciativa do Che Guevara em criar a primeira escola de design em conjunto com Clara Porset em 1963, aquele mencionado projeto que não se conseguiu concretar nesse momento

[...] En numerosos artículos, documentos y conferencias de esos años [Che] afirmó explicitamente que veía el desarrollo de la industria nacional como medio para propiciar objetos con calidad y diseño para toda la población (Fernández L. , 2012, p. 8).14

Outra comprida lista de eventos foram estimulados por diferentes agências governamentais em diferentes frentes e relativamente diversos atores. Indústrias para diferentes necessidades modernas foram instaladas, como INPUD -Industria Nacional Productora de Utensilios Domésticos-, mais a frente o ICIODI -Instituto Cubano de la Investigación y Orientación de la Demanda Interna-, etc. Essas ações foram acompanhadas das consolidações acadêmicas dos anos setentas quando foi iniciada a breve Escuela de Diseño Informacional e Industrial -EDII, entre 1970 e 1978-, na que está envolvido o trabalho de Iván Espín, e a gestão do Ministério da Indústria Ligeira que tinha organizado Che Guevara nos anos 1960. Como já mencionei várias vezes, Espín é o futuro fundador da ONDI assim como da ALADI, da qual será o seu presidente em duas ocasiões: 1982-1984 e 1989-1991

[...] En julio de 1980 a instancias de Espín se creó la ONDI (Oficina Nacional de Diseño Industrial adscripta a la Junta Central de Planificación), siendo él su director hasta 1988. Los objetivos de su razón de ser fueron contribuir a la efectividad de la producción industrial y elevar el nivel del diseño y la calidad de los produtos (Fernández L. , 2012, p. 13).

\footnotetext{
14 No pé da página do seu artigo, Fernandéz menciona vários desses documentos. Os anos são 1961, 1962, 1963 e 1964 (Fernández L. , 2012, p. 16).
} 

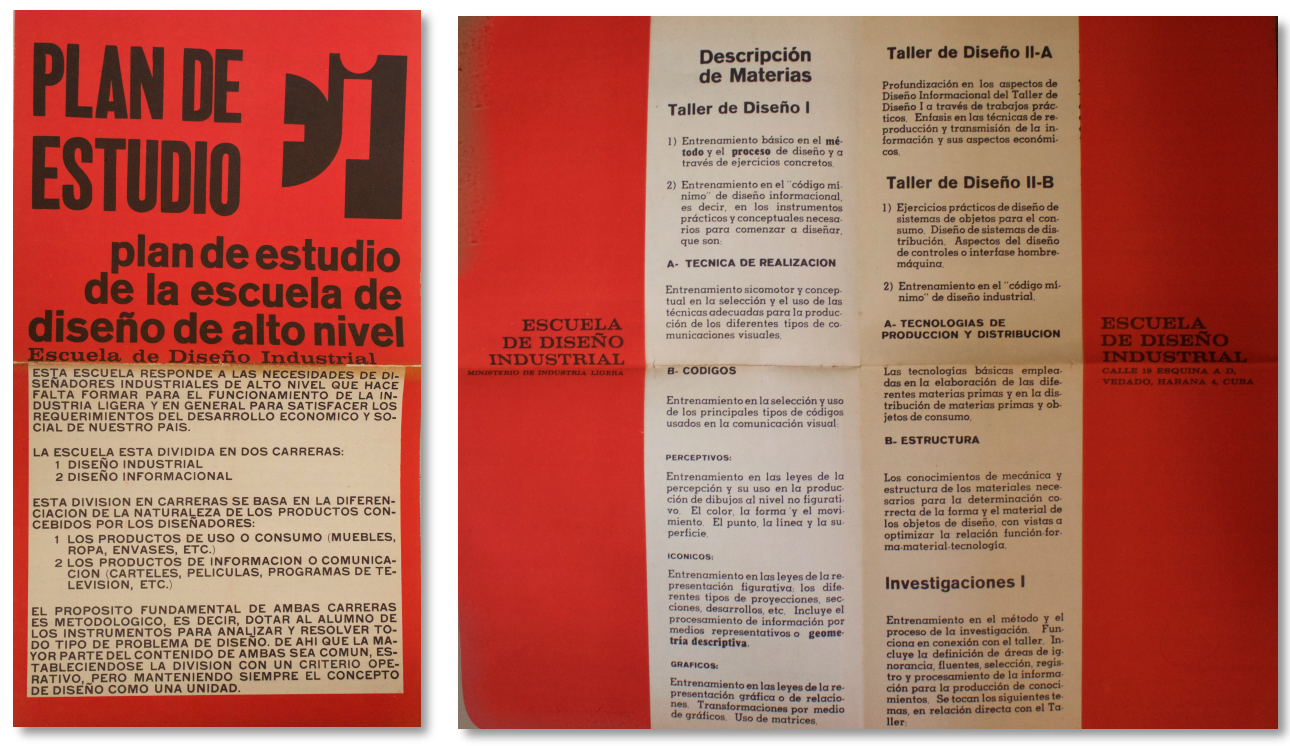

Figura 8. Folheto Plan de Estudio Escuela de Diseño Informacional e Industrial (EDII) de Cuba 1970. Acervo pessoal de Santiago Pujol, Havana, Cuba (APSP).

\section{A união faz... besteira!}

1.

A configuração de corpos associativos poderiam marcar a cúspide dos processos de profissionalização. Digo poderiam porque, na prática, os processos sociais manifestaram facetas extraordinárias que escapam dos limites da teoria. Às reflexões sobre o profissionalismo compreendido como uma lógica independente aos processos de estabelecimento de um nicho de mercado laboral e à configuração de conclaves acadêmicos que organizavam a formação nos esoterismos do que trata o objeto social da profissão, soma-se a configuração de corpos associativos que em geral funcionam para defender a independência do campo. Independência para definir os limites da sua jurisdição -no trabalho dos especialistas-, quanto os sentidos da sua discricionalidade e por tanto as formas, cores e texturas do seu papel social. Independência para avaliar o trabalho dos colegas por seus pares, mas também independência para lutar contra a entrada de intrusos no campo. É, no sentido mais geral, um grito de autonomia, na complexidade que defende García-Canclini, como um dos indicadores mais claros de modernidade. O local aonde tais debates, reflexões, acordos e reivindicações se estabelecem é -em geral- o corpo de pares, uma instituição com autogovernação e autodeterminação. 
Argentina, Brasil, Colômbia, Costa Rica, Cuba, Equador, México, Guatemala e Porto Rico, todos de diferente maneira tinham estabelecido certos mercados profissionais para designers nos anos setentas. Com certas antecedências -apenas explicadas nas historias nacionais-, em 1980 esses nove países -que fundaram ALADI- já contavam com profissionais atuantes de forma recorrente e autônoma no campo do design.

Os casos isolados de profissionais que iniciaram antecipadamente a sua atuação estavam próximos de completar 20 ou 25 anos de formação em cursos especializados; os outros -a grande maioria- estavam inseridos na grande onda de criação de programas acadêmicos que para 1980 completava 11 anos -aquele ciclo que marquei com a criação do curso de design industrial da UNAM no México em 1969-. Desses nove países que assinaram a fundação da ALADI em Bogotá em 1980, só não consegui determinar se o Porto Rico e o Equador tiveram um corpo associativo de designers que defendesse a jurisdição e a discricionalidade do campo. Os outros -com a exceção da Guatemala, que esteve representada na ALADI por membros da associação nacional de arquitetosforam representados em Bogotá por associações especializadas de designers, as mais antigas, inclusive, completando quase 20 anos em Bogotá. Grosso modo, nos diferentes países da região aqueles corpos associativos adquiriram forma no seu cenário nacional por diferentes razões e -a meu ver- ao menos atendendo aos três grandes 'chamados' relacionados com o design: promoção e difusão; luta da categoria, com claras vindicações políticas e de permanente luta com o Estado para regular o mercado laboral e o ensino; causas cruzadas que misturavam o interesse de impactar a realidade por meio do Estado e que também buscavam difundir e promover os alcances da disciplina. ${ }^{15}$

De determinada forma, dependendo do país, parece que esses corpos associativos, respondendo às suas respectivas vocações ou chamados, seguiam também ao menos três orientações: por uma parte, houve associações com clara inclinação internacionalista, em uma atitude que parecia querer conectar aquela associação e os seus membros dos acontecimentos do design internacional, principalmente -óbvio- os países desenvolvidos. Uma segunda parecia buscar a ligação do corpo associativo com o Estado por meio do estabelecimento de uma figura corporativa típica da época. A

\footnotetext{
15 Quando digo 'chamado' o faço pensando na interpretação que faz Eliot Freidson das ideias de Max Weber. Quando o britânico o cita, homologa na obra weberiana a ideia da "vocação" com o "chamado secular", no qual esta baseado o espírito do profissionalismo segundo Freidson (2001).
} 
terceira, parecia mais focada nas delimitações do campo como tal. Agora, é necessário dizer que na prática das diferentes associações -e havendo ainda muito por estudar nesse assunto- não é possível afirmar que nem as que chamo 'vocações' nem as que denomino 'orientações' sejam grupos que respondam a categorias mutuamente excludentes. As misturas, na América Latina do pesadelo, também estão presentes nas associações de designers.

\section{2.}

Para mencionar o primeiro tipo de chamado ou vocação, posso mencionar que os dois casos mais notórios que defendiam a promoção e difusão do design nos seus respectivos países podiam ser por sua vez os mais antigos: a Asociación de Diseñadores Industriales de Argentina -ADIA-, criada em Buenos Aires em 1962 (Carranza, 2014), e a Associação Brasileira de Desenhistas Industriais -ABDI-, criada em São Paulo em 1963. Além das vocações, os dois casos se parecem pelo fato de que nas cidades que influenciavam não havia designers formados como tal durante a década -em Buenos Aires, ainda, até 1984- mas sim arquitetos e engenheiros interessadíssimos no assunto. De fato, vários deles completamente voltados ao mercado profissional de design, como precursores de várias linhas de projeto tanto na Argentina, quanto no Brasil.

Com relativa coincidência também, cada uma dessas associações estava interessada em promover concursos, fazer exposições e por momentos, criar vínculos com os assuntos da formação. Esse último mais ligado a cursos de curto prazo ou seminários, do que em uma relação com cursos longos em universidades. Da sua própria maneira se relacionavam com os profissionais que estavam no mercado integrando-os à associação. Da mesma forma, aproximaram-se de câmaras de comerciantes ou federações de industriais para sensibilizá-los a respeito da importância da disciplina. As duas, por exemplo, tiveram como membros do seu corpo não só designers como industriais, empreiteiros e comerciantes

[...] 0 estatuto da ABDI definia a Associação como "sem fins econômicos" e "de caráter cultural". Os objetivos da entidade abrangiam cinco ações principais: a) reunir [...] e servir de fórum de aproximação com quaisquer interessados no desenvolvimento do desenho industrial no Brasil; b) atuar "na criação de condições favoráveis ao desenvolvimento do desenho industrial" e " contribuir para qualificação técnico-formal e cultural do produto industrial" por meio de diversificados eventos e ações; c) "divulgar e documentar as atividades dos sócios"; d) assessorar os sócios em suas relações profissionais, destacando o registro autoral na própria $\mathrm{ABDI}$; e) "desenvolver gestões no sentido do reconhecimento 
e regulamentação da profissão. As ações de divulgar e conscientizar conceitos sobre o que é design, tiveram maior atenção dos fundadores da Associação (Braga, 2011, p. 80 e 81).

Com as variações correspondentes, esse mesmo tipo de ideias era privilegiado no interior da ADIA argentina e os seus órgãos de apoio -o INTI e o CIDI que mencionei, e o CAyC que foi criado no final da década-, como interpreto pelas minhas conversas com Hugo Kogan, Roberto Napoli, Ricardo Blanco e Carlos Sallaberry, principalmente. Como disse, os detalhes devem ser aprofundados em uma pesquisa dedicada nisso

[...] Ellos participaban de lo que en su momento fue [...] ADIA. Asociación de Diseñadores Industriales de la Argentina, de la cual nunca pude ser sócio porque nunca tuve antecedentes para estar ahí. Eso marcaba, también, una visión grupal que estaba patrocinada por el CIDI. No nos olvidemos que el CIDI y esta es una cosa muy fuerte para mi lectura y para mi desarrollo, se había formado con varias empresas, casi todas de producción. Ricardo Blanco (INTI. Programa de Diseño, 2007, p. 22). ${ }^{16}$

A ABDI não participou da ALADI ao contrário da ADIA argentina. Dessa última, alguns dos seus membros participaram decididamente desde o princípio da fundação e montagem da associação latino-americana, vendo nela a oportunidade por fazer o que vinham fazendo na Argentina: divulgar e promover o design. Menciono novamente como Basílio Uribe, importante promotor do INTI, o CIDI e a ADIA, esteve presente tanto na segunda quanto na terceira reunião de configuração da ALADI. O nível de envolvimento com a ideia da ALADI pode chegar ao fato de afirmar que foi entre Uribe e os mexicanos da CODIGRAM que foi iniciada a ideia da associação em 1974, como afirma Rey ao menos em dois momentos: na conversa que teve com Blanco e Bernatene -conduzida por Carolina Muzi- em 2007 (INTI. Programa de Diseño, 2007), assim como nos anexos do seu livro de história do CIDI (Rey, 2009).

A experiência desse grupo de argentinos com aquela vocação -difusão e promoção-, desenhou uma forma bem precisa de compreender a orientação da ALADI, estabelecendo uma linha rígida no interior da associação. Quem sabe se no pragmatismo em que repousa aquela postura é que possa ser compreendido o olhar de Carlos Sallaberry, o qual não via pertinência dentro da ALADI quando defendia princípios afastados do núcleo da promoção do Design Industrial regional. Ainda mais, a partir

160 CAyC, foi o Centro de Arte y Comunicación, criado em 1969 por Jorge Glusberg em Buenos Aires. Embebido em um sugestivo espírito internacionalista, o Centro tinha o propósito de difundir as vanguardas, em especial aquelas que estavam se produzindo na Argentina. A partir de 1977, Sallaberry chefiou o seu Departamento de Diseño. 
desse pragmatismo é possível até posicionar a anedota de Roberto Napoli em Bogotá, nas reuniões que inauguraram ALADI. Segundo ele, o cenário não era exatamente confortável; por uma parte a impertinência das glosas -como também opina Sallaberry-, por outra o radicalismo de certas perspectivas que se tornavam até mesmo agressivas.

Vale mencionar que efetivamente sendo epicentro da representação da Argentina no processo fundacional da ALADI, ADIA não é a única organização associativa envolvida no assunto. Segundo os relatos de Rey (2009), diferentes corpos colegiados de designers já existiam no país no segundo lustro dos anos 1970, os quais, na conjuntura de criação da ALADI em Bogotá em 1980, decidiram criar um corpo que reunisse a todos -como antecedendo os que serão chamados de Comités Nacionales de ALADI-. Esse novo corpo chamado CADI -Comité Argentino de Diseño Industrial-, entre outras coisas, define que só ele representa a Argentina na associação latino-americana, escreve um documento para a ALADI, assim como elege os representantes argentinos para a assembleia fundacional na Colômbia "de la elección de los 14 representantes de las entidades, surgieron por votación Julio Colmenero y Roberto Napoli como representantes titulares" (Rey, 2009, p. 405).17

3.

Como disse anteriormente, o núcleo que representou os brasileiros na ALADI não foi a associação brasileira sediada em São Paulo -ABDI-. No seu lugar, a grande movimentação brasileira se deu por iniciativa da APDINS -Associação Profissional dos Desenhistas Industriais de Nível Superior do Rio de Janeiro e Pernambuco-, organização pré-sindical e estadual, como caracteriza Marcos Braga (2011, p. 125). A ebulição de diferentes fenômenos no país criou uma força no Rio de Janeiro na segunda metade dos anos setentas que deu origem à Associação. Derivando do desmonte da regional da ABDI no Rio de Janeiro, assim como de diversas pressões que aparecem no cenário no relativo ao currículo mínimo dos designers e o status do profissional formado no mercado de trabalho, um grupo significativo de designers cariocas -gentilício para o nascido no Rio

\footnotetext{
17 Aqueles corpos foram: CIDI, Centro de Investigaciones en Diseño Industrial, representado por Julio Colmenero e Beatriz Galán; SDI, Sociedad de Diseñadores Industriales, por Rubén Peluso e Mario Amisano; SDO, Sociedad de Diseñadores del Oeste, por Gerardo Díaz e Rolando Espina; ADIBA, Agrupación de Diseñadores Industriales de Buenos Aires, por Roberto Napoli e Emil Taboada; CAYC, Centro de Arte y Comunicación, por Carlos Sallaberry e Ricardo Blanco; UNLP, Universidad Nacional de La Plata, por Roberto Doberti e Ricardo Denegri e finalmente o IDI, Instituto de Diseño Industrial de la Universidad de Rosario, por Jorge Vila e Enzo Grivarello.
} 
de Janeiro- se reuniu a partir de 1976 para debater temas de interesse do campo em relação com as circunstâncias e produziram durante aqueles 3 ou 4 anos, uma volumosa quantidade de reflexões e documentos -vários desses foram entregues pela delegação brasileira no primeiro congresso da ALADI em Bogotá em 1980-. Todo esse processo acabou por formar a APDINS em 1978

\begin{abstract}
[...] Ao longo do ano de 1977, a ideia de formação e da existência de entidades pré-sindicais, de nível estadual, convivendo com a ABDI, é aceita por todos, já que seus objetivos e ações eram considerados distintos, e até complementares, no cenário de organização da categoria profissional. Mas, na prática, os designers cariocas voltavam-se mais para a organização das entidades pré-sindicais, aproveitando a mobilização dos profissionais no Rio de Janeiro. Os paulistas [gentilício do nascido em São Paulo], apesar de apoiarem a via sindical, em paralelo à $\mathrm{ABDI}$, empreenderam ações que consideravam mais pertinentes para a Associação pioneira (Braga, 2011, p. 130 e 131).
\end{abstract}

Seguindo Braga (2011, p. 133), a criação da APDINS marcou uma espécie de atualização nas relações do cenário político e social com a realidade dos designers e o seu papel no Brasil. Regulamentação profissional, estudos sobre a situação do mercado de trabalho, organização de eventos de aprimoramento profissional, formação de um código de ética profissional e a discussão sobre o ensino e o currículo mínimo, eram as respostas que vários dos associados compreendiam como necessidades para enfrentar na alvorada da década dos anos 1980. Claramente, uma forma diferente de entender a ideia de corpo associativo. Se aquela primeira versão de associação -representada em ABDI e a ADIA argentina que expus no numeral anterior- visava a promoção e difusão tanto dos sentidos da profissão, como dos artífices das diferentes obras, é claro que aquelas necessidades em torno do fortalecimento e proteção do campo profissional as extravasavam rapidamente. As diferentes lutas e reivindicações engendradas nesse percurso foram as tarefas que se representavam na criação da APDINS.

A documentação apresentada pela delegação brasileira em Bogotá assim como a reconstrução histórica feita por Braga, me permite tratar aqui o caso brasileiro, ainda que seja de forma muito superficial. Dada a escassez de dados nos outros casos, me parece muito complicado ver algum dos outros corpos associativos nacionais dentro das características que marcavam a APDINS como associação. Pode ser que outros corpos também estivessem orientados na mesma direção, dadas -entre outras coisas- as circunstâncias da época: luta contra o autoritarismo político na região toda, suspeita de intromissão norte-americana e promessas frustradas do desenvolvimentismo-. 
4.

Atrevo-me a pensar que na combustão da época, tanto as movimentações mexicanas, quanto as colombianas e costarriquenhas tenham transitado por caminhos parecidos com o tom da APDINS. As minhas conversas com alguns dos envolvidos me sugerem pensar nisso. Mas, se essas conversas iluminam essa vocação, também é verdade que outras tantas aproximam vários desses corpos naquela orientação semelhante a dos argentinos e brasileiros da ABDI. Ainda pode ser necessário muita mais informação para afirmá-lo, mas gostaria de sugerir uma terceira vocação a partir de certos indícios. Peço desculpas se abuso dos fatos.

Por exemplo, existia uma grande atividade associativa sobre o design no México durante os anos 1970. Segundo os documentos apresentados pela delegação mexicana em Bogotá em 1980, algumas memórias de eventos da época -como a cronologia feita para o XI Congresso do ICSID (Ramírez, P. et al., 1980)- e textos, como o escrito por Gerardo Rodríguez (1987), em 1980 existiam ao menos seis associações de designers no país. ${ }^{18}$

Uma primeira inquietude me surge no momento em que tento compreender a existência de tal quantidade de associações de designers -todas quase igualmente jovens- no cenário de um país em processo de desenvolvimento como o México -a mesma pergunta me surge no caso argentino que apresentei nas páginas anteriores-. Das seis organizações provavelmente existentes até 1980, parece que o Diseñadores Industriales. Instituto Técnico Político Nacional e o CODIGRAM eram corpos associativos especializados, criados por designers para ser orientados por designers, órgãos autônomos que pretendem definir os limites da jurisdição e a discricionalidade da profissão. As duas mais antigas, parecem ser produto da associação de arquitetos que querem determinar o sentido do design, no que, claramente não parecem se reconhecer todos os designers mexicanos -me parece que fundar o Instituto (DIITPN) e CODIGRAM é evidência disso-.

Agora, porque então fundar dois corpos de designers por designers quase que no mesmo instante? Não tenho resposta para essa pergunta, mas minhas interpretações podem iniciar precisamente tentando contornar a pergunta. A fundação do Instituto e do

\footnotetext{
18 A Asociación Mexicana de Diseñadores A.C. (AMDAC) criada em 1962, Diseñadores Industriales de México A.C (DIMAC), fundada em 1972, a Diseñadores Industriales, Instituto Técnico Político Nacional A.C (DIITPN) em 1973, o Colegio de Diseñadores Industriales y Gráficos de México (CODIGRAM) em 1975, a Asociación de Diseñadores Artesanales em 1976 e a Asociación Mexicana de Estudiantes de Diseño Industrial em 1979.
} 
Colegio está separada por dois anos -1973 o primeiro 1975 o segundo-. Claramente os membros fundadores do Colegio não se sentiram representados no Instituto e decidiram se organizar aparte. 0 Instituto tinha uma clara vocação corporativa com o PRI -Partido Revolucionario Institucional- que para 1973 já completava 44 anos no poder, com oito presidentes da república de forma consecutiva e vários descontentes, principalmente dentre as gerações de jovens estudantes dos anos 1960. Um dos personagens mais importantes do Instituto foi Alejandro Lazo, filho de Carlos Lazo, ministro de comunicações e obras públicas no momento da sua morte. Carlos Lazo foi o pai político de Pedro Ramírez Vásquez -entre muitas coisas, presidente do Comité dos Jogos Olímpicos e ativa figura do PRI- que por sua vez era o pai político de Alejandro Lazo. Alejandro Lazo, além disso, foi membro fundador da ALADI, assim como do Executive Board do ICSID entre 1979 e 1981.

Com um discurso relativamente abstrato, o Instituto parecia perseguir a ideia de ser o braço especializado de designers do governo priista

[...] Las necesidades crecientes, el processo de industrializaión, los factores de la economía interna, reclaman con urgencia el esfuerzo y la acción coordinada de todos los mexicanos y en el caso de los diseñadores, una actividad conjunta que permita hacer llegar a los sectores populares los benefícios de los objetos correcta y satisfactoriamente diseñados. Luchemos porque en México se difunda el buen diseño de origen nacional. El gremio unido, ha de luchar por hacer proliferar el diseño destinado a los sectores populares, debilitando con ello el diseño elitista destinado a unos cuantos que pueden pagarlo y que a más de limitar la naturaleza de la profesión deja de tener sentido, pues es contradictorio con las características de la vida de nuestro tiempo. Trecho dos estatutos da associação Diseñadores Industriales Instituto Técnico Político Nacional A.C, citado no texto cronológico feito pela organização do XI Congresso do ICSID na Cidade do México em 1979 (Ramírez, P., et al., 1980, p. 15 e 16).

Carlos Lazo esteve intricadamente relacionado com o projeto urbanístico e arquitetônico da Cidade Universitária da UNAM e também foi fundador da Escuela de Diseño y Artesanias em 1952 -junto com a Escola de Desenho Industrial do Instituto de Arte Contemporânea de São Paulo, uma das escolas mais antigas de design na região-. Tanto a herança política quanto a prática gremial do seu pai, dão um aparente empurrão para que Alejandro consiga configurar grupos de base como o Instituto, plataforma que lhe permite promover a ideia de organizar um congresso do ICSID no seu país e ser nomeado parte do Board durante dois períodos consecutivos 
[...] Alejandro tenía una visión política muy clara. Él quería ser presidente del ICSID y estaba dando los pasos para lograrlo. Además tenía la capacidad para hacerlo. Es decir, tenía la visión, las opciones y las oportunidades, sobre todo de movilidad y de presencia política (Polo, 2014a).

Não eram poucos os designers que não gostavam daquela relação entre um grupo de profissionais da sua área com o PRI. "O ogro filantrópico”, como o denominou Octavio Paz, tinha estado relacionado com claros atos elitistas e ferozes ações de autoritarismo como a massacre de Tlatelolco em 1968. Muitos dos designers que trabalhavam durante os anos setentas eram jovens estudantes naquele momento, alguns deles participantes das diferentes manifestações as que causam e as que foram consequência daquele ato pelo Estado mexicano. Vários desses estudantes eram filhos de migrantes de regimes autoritários. Todos eram sujeitos com determinada sensibilidade política, que no mínimo se manifestava contra a estrutura elitista. A maioria deles ainda hoje se manifesta distante das ações do Instituto e veem com suspeita a figura de Alejandro Lazo, ou ao menos, foi isso que percebi nas minhas conversas com vários deles.

Em todo caso, e além daqueles detalhes, me parece evidente que o Instituto caminhava por uma via na qual não se sentiam representados muitos dos designers que se desempenhavam no campo profissional. A partir daí, misturando um pouco as ideias da promoção e a divulgação, fez-se possível a formação de uma outra associação que apostava nas definições da jurisdição e a discricionalidade do campo do design mexicano. A sua vocação aparecia misturada entre as duas inclinações

[...] La actividad professional que nos une es el diseño como parte de un sistema professional en el que se dan relaciones en movimento, en el espacio y en el tiempo. Consecuentemente tales relaciones deben estructurarse mediante un código. José Antonio Martínez. Tomado do Boletín informativo No. 2 del Colegio de Diseñadores Industriales y Gráficos de México A.C. (CODIGRAM) de setembro de 1976 p. 1 (Ramírez, P. et al., 1980, p. 17).

Posso, ainda, generalizar que no caso da Colômbia com a Asociación Colombiana de Diseñadores -ACD-, criada em 1976, a questão foi parecida com a da CODIGRAM. Já mencionei que era uma agência do governo colombiano que propunha a sua formação seguindo as diretrizes da Missão Belga. Nesse momento, se organizaram os atores principais do mercado profissional, alguns dos quais completavam para esse momento 20 anos de trabalho em design. Os frentes da ACD também manifestavam seu interesse na promoção e divulgação e nas delimitações do campo e a inserção da profissão nas 
estruturas públicas como intuito para impactar a realidade, que é a mesma estrutura geral que percebo do corpo costarriquenho fundado por Franca Rosi e Oscar Pamio em 1979.

Essa era a realidade gremial que chegava em Bogotá em 1980 para fundar ALADI. Ao menos três tipos de vocação com diferentes orientações operacionais. Organizações que trabalhavam desde o fortalecimento do campo no seus locais de influência, por meio da delimitação dos objetos de trabalho, das competências intelectuais e dos níveis de formação para o desempenho, até grêmios de profissionais que pretendiam se ligar ao cenário internacional do design para -entre outras coisas- deixar o registro do trabalho do design nacional nos 'registros cosmopolitas'. Aposta essa que pretendia levantar o nome dos autores acima, inclusive, dos produtos que elaboravam, para parafrasear Ricardo Blanco (2016).

Fenômenos acontecendo, criações se argumentando, interesses defendidos, indivíduos intoxicados e procurando estabilidades de diferentes contornos compunham esses corpos e esses processos. Eis alguns processos do design nesta periferia. Tal é o tamanho dessa complexidade. Tal é a forma dos encontros que inauguraria a ALADI a partir de 1978. 


\section{Parte 2.}

O design se explica pelas circunstâncias sociais que o produzem, nas condições da América Latina do pesadelo, exotismo e sonho... 


\section{Origens e motivações}

[...] ALADI nace en un momento histórico crucial, buscando afianzar, a través de la unión, la afirmación de un Diseño Industrial propio, en contra de quienes quieren negarle a Latinoamérica la capacidad de estructurar su propia realidad (Pamio, 1981, p. 1).

ALADI é uma organização que reúne profissionais do design desde 1980. Procurando um exercício disciplinar autônomo, ela foi fundada em Santandercito, Cundinamarca na Colômbia em novembro de 1980, sob um claro discurso reivindicatório no qual estava em jogo a defesa e a construção do campo -nas esperadas dimensões profissionais e acadêmicas-, assim como a luta em favor da libertação cultural a partir da autonomia tecnológica e a quebra da dependência dos países da América Latina. Respira nela um espírito que, com as suas proporções, pode ser rastreado nos intelectuais da região desde o próprio século 19 . Um espírito latino americanista que irriga o seu coração.

Aquela assembleia fundacional em Santandercito contou com a presença das delegações de nove países: Colômbia, Cuba, Brasil, México, Argentina, Costa Rica, Porto Rico, Guatemala e Equador, delegados suplentes colombianos, observadores argentinos, mexicanos, hondurenhos e colombianos, assim como a equipe organizadora da ALADI/Colombia (ALADI, 1980a, p. 1). Essa reunião converteu-se no ponto de partida de um ambicioso projeto coletivo que, em geral, teve como eixo central o debate sobre o papel da profissão no contexto regional e que aparentemente, se estende até 1995, quando a Colômbia entrega a presidência para a Argentina.

Essa transferência não significou a dissolução da ALADI. Tudo parece indicar que foi até aquele momento, talvez até 1993, que a Associação parece se dirigir seguindo as heterogêneas diretrizes iniciais, conseguindo uma certa integração disciplinar na região, como pode ser constatado pelo seu reconhecimento como organização consultiva pela ONU (Organização das Nações Unidas) em 1991, ou no fato de organizar congressos com assistência de mais de 700 pessoas -como pelo menos aconteceu no Rio de Janeiro em 
1984, e Santa Marta em 1993-, assim como pelas exposições de designers e encontros de estudantes da América Latina. ${ }^{1}$

Desde o estabelecimento da presidência argentina em 1995 até os dias atuais, o ritmo, o tom, a representação e, inclusive, a identidade visual da associação parecem ter variado substancialmente. Os estatutos iniciais estabeleciam que a sede da presidência mudaria a cada dois anos, sendo sediada em diferentes países-membros, como aconteceu até 1993.² Não aprofundarei aqui, mas pelo visto é possível dizer que aquela alternância também mudou. Os congressos, aparentemente menores e menos representativos -ALADI representaria principalmente organizações e instituições nacionais- mudaram de interesse temático sobre questões mais empresariais e/ou comerciais. $^{3}$

Essas mudanças poderiam ser explicadas a partir de vários ângulos que ainda não tratarei. Contudo, adianto que todos eles podem estar envolvidos com assuntos que vão desde os mais pessoais nos diferentes atores do processo, a questão geracional que teve a associação dada a aposentadoria de vários dos membros fundadores ou a morte de alguns deles, até aos assuntos mais estruturais, relativas à crise moral e econômica na qual a América Latina mergulhou durante os anos 1990 até meados dos anos 2000.

O narrado nesses últimos parágrafos é um resumo do acontecido com a ALADI de Bogotá 1980 à frente, com o propósito de desenhar um contexto geral. Neste capítulo, no entanto pretendo tratar o que ocorreu antes daquele começo. 0 meu propósito é compreender o que tornou possível que um grupo de designers latino-americanos embarcarem em um projeto, usando, inclusive, seus recursos pessoais em vários momentos.

\footnotetext{
${ }^{1}$ Segundo os números da organização, a 1aㅡ Exposição Latino-Americana de Desenho Industrial, feita no Museu de Arte Moderna do Rio de Janeiro no marco da 3ª ALADI em 1984, contou com a participação de 5.000 pessoas (Edelman \& London, 1985, p. 1).

${ }^{2}$ Aquele ritmo só sofreu um revés entre 1986 e 1989. Segundo o que foi estabelecido em Cuba em 1982, o Brasil teria a presidência entre 1984 e 1986, e a Nicarágua, entre 1986 e 1988. No entanto, pelo que entendo da ata de Petrópolis -novembro de 1984-, os nicaraguenses tiveram problemas até para ir ao Rio de Janeiro, abandonando a sua candidatura como 2a Vice-presidência. Isso motivou uma nova escolha na plenária da assembleia no Brasil. Foi votado que o México a teria em 1986-1988 e a Argentina em 19881990 (ALADI, 1984). Contudo, os mexicanos não a conseguiram organizar o evento, assim como os argentinos também não. Para que a Associação permanecesse em funcionamento, foi decidido que Cuba ficaria com a sede novamente. Dessa forma, Cuba organizou a $4^{\mathrm{a}}$ ALADI e ficou na presidência entre 1989 e 1991, ano em que passou ao México.

${ }^{3}$ Com as suas próprias diferenças, os primeiros congressos foram orientados para discussões sobre a institucionalização do design, seu papel social na região, as suas relações com os diferentes setores sociais etc. Sobre isso voltarei em próximos capítulos.
} 
Dada a lógica do meu argumento, dividi o processo de criação e implementação da Associação em três partes. A primeira reúne as quatro reuniões em que a ideia de criação da ALADI foi gestada e aprimorada, entre janeiro de 1979 e junho de 1980. Essa parte é predominantemente descritiva -muito mais do que eu gostaria-, pelo que peço paciência na sua leitura. A segunda parte é o momento no qual nasce a ideia de criar uma comunidade como a ALADI. Esse momento é cronologicamente o primeiro e ocorre no México entre 16 e 30 outubro de 1978, dois meses antes da primeira dessas quatro reuniões mencionadas antes. A terceira parte desse capítulo pretende dar um cenário ao acontecido no México. Um momento significativo em que se encontram e cruzam as realidades de vários latino-americanos, assim como parecem se materializar os ideais de mudança social com os que estavam apaixonados há anos. As duas últimas partes já começam a tecer fios, entrando num ritmo mais movimentado e -espero- entretido para o leitor. 


\section{Véspera, completas, matinas, laudas e prima ${ }^{4}$}

[...] 0 caso é o seguinte: eles tinham um instituto indiano de tecnologia em Bombaim e uma escola em Ahmedabad [...] Quando nós chegamos já estavam fazendo um tributo ao fundador... ele já estava falecido... mas foi o cara que lançou essa ideia de design lá para a Índia e ele fundou essa escola [...] muito bem instalado, uma coisa... foi lá o início do encontro que depois foi para esse Instituto Nacional de Tecnologia Indiano (Abramovitz, 2013).

\section{Ahmedabad e Bombaim, janeiro de 1979}

1.

Inicio essa parte abrindo um parênteses a fim de aproveitar a ideia da citação e ir deixando algumas coisas sobre a mesa. Nesta entrevista com José Abramovitz, ele não consegue se lembrar do nome do criador da escola de design em Ahmedabad, relacionado com o evento promovido na Índia em 1979. Durante a entrevista, ele só lembra que é um dos nomes do design internacional vinculado ao ICSID. A partir de três indícios -a proximidade com o ICSID, sua origem americana e as datas nas quais aconteceu a fundação de uma das escolas de design mais famosas da Índia em Ahmedabad (1957-1961)- é possível afirmar que aquele criador é ou Charles Eames e sua esposa, tão ativos na relação com a Índia nesse momento, ou ainda o próprio Peter Müller-Munk, co-fundador e primeiro presidente do ICSID. Por um lado, o casal Eames teve estreito contato com a família Sarabhai que fundou o instituto de design, especialmente com o Gautam Sarabhai e sua irmã Gira. ${ }^{5}$ Elisa Alessandrini explora em seus textos o nível da relação entre eles (Alessandrini, 2012; 2014).

Porém, as memórias de Arthur Pulos também trazem a tona o nome do co-

\footnotetext{
${ }^{4} \mathrm{Na}$ nota inicial da edição em espanhol de 1994, Umberto Eco apresenta essas divisões do dia, usadas por Adso de Melk naquela mesma abadia medieval "cuyo nombre incluso conviene ahora cubrir con un piadoso manto de silencio" em 1327, onde, embebidos na rigorosa vida monástica, se deu a história de $O$ nome da Rosa. Essas divisões têm referência em finais de novembro na Itália Setentrional (local no que acontece o romance), onde o sol nasce por volta das 7 h30 e se põe cerca das 4 h40 da tarde. Seguindo sua descrição e usando-a no meu relato: véspera: entre $4 \mathrm{~h} 30$ e $4 \mathrm{~h} 40$ da tarde (pôr do sol); completas: cerca das $6 \mathrm{~h}$ da noite; matinas (Vigiliae): $2 \mathrm{~h} 30$ e 3h da noite; laudas (Matutini): entre as $5 \mathrm{~h}$ e $6 \mathrm{~h}$ da manhã (termina rompendo a alva); prima: cerca das 7h30, antes da aurora (Eco, 1994, p. 10). 0 leitor reconhecerá naquele romance as estreitas ideias com as lutas pelo poder, a vocação e os seus sentidos de chamado, a mudança de mentalidade e a primazia ideológica.
}

${ }^{5}$ Segundo a própria resenha do National Institute of Design, esse é o tempo ocorrido entre a visita do casal Eames e a fundação formal pela família Sarabhai (NID, 2014). 
fundador do ICSID, Peter Müller-Munk. Segundo Pulos, Müller-Munk não só esteve na Índia naqueles anos sendo parte das missões técnicas assinadas entre o ICSID e ICA International Cooperation Administration, depois chamada USAid United States Agency for Internacional Development- e da ICA com o governo indiano, se não que igualmente redigiu alguns relatórios nos quais recomendava o estabelecimento de training centers em várias cidades da Índia (Pulos A. , 1988, pp. 236-241).

Esses tipos de projetos eram bastante comuns entre as diferentes instituições internacionais como o ICSID e o USAid, o que pode explicar o trânsito de vários dos nomes do design por países tão distantes como a Índia, a Indonésia, a Turquia, a Jamaica e a Argentina, para citar alguns exemplos. Pulos mencionou uma lista de processos desde os anos 1950 que cobriam vários países no mundo inteiro. Aquele transito configura desde relações profissionais e de amizade entre os estrangeiros e os designers locais, até imagens de ameaça profissional e cultural, como parece ser frequente em várias ramas de intelectuais latino-americanos. Sobre isso falarei mais a frente.

\section{2.}

Fechando o parênteses, um evento sobre design para desenvolvimento industrial foi realizado na Índia entre 14 e 24 de janeiro de 1979. Esse encontro foi promovido pela aliança entre o UNIDO (Organização das Nações Unidas para o Desenvolvimento Industrial em inglês) e ICSID (1979).

Naquele cenário, encontraram-se o argentino Basílio Uribe do CIDI (Centro de Investigación de Diseño Industrial), o brasileiro José Abramovitz do INT (Instituto Nacional de Tecnologia) e o colombiano Rómulo Polo da PUJ (Pontificia Universidad Javeriana). De acordo com Abramovitz e Polo, Gui Bonsiepe -nesse momento domiciliado na Argentina- também estava presente.

Como expus no capítulo anterior, essas três instituições -CIDI, INT e PUJ- foram importantes entidades promotoras do Design Industrial em seus respectivos países. Como expõem José Rey (2009) ou Verónica Devalle (2009), o CIDI foi fundado em 1960, tentando realizar o que se tinha pensado e conceitualizado até esse momento na Argentina sobre design e a sua relação com o desenvolvimento industrial.

Como lembra Luiz Blank (2014), no caso do escritório de Desenho Industrial do INT, o propósito era dar forma ao programa "06" criado pelo governo brasileiro naqueles anos, dentro do esquema de desenvolvimento de tecnologia de ponta. 
As variações são significativas, contudo CIDI, INT e também PUJ parecem gravitar em torno da concepção do design como ferramenta de desenvolvimento tecnológico. A institucionalização do design e o seu fortalecimento supõe a conquista do desenvolvimento industrial, assim como o desenvolvimento social, por meio da satisfação das necessidades das povoações no seu próprio contexto.

A estrutura do evento na Índia queria debater o papel do Design Industrial nos países subdesenvolvidos para "aliviar" os seus problemas. Nessa linha de raciocínio, a organização propôs visitas em Ahmedabad para conhecer a famosa escola de design, as suas apostas educativas e o seus conteúdos, assim como aquela viagem para Bombaim, para visitar aquele centro tecnológico "exemplar", que lembra Abramovitz. Esse centro tão ligado com o desenvolvimento industrial da cidade e daquela região do país. 0 evento também teve sessões de palestras dos vários representantes ali reunidos.

No dia 23 de janeiro, um dia antes de terminar o evento, esses três latinoamericanos se reuniram e estudaram o Documento de Intención, feito no Interdesign 78 dois meses antes, que mais a frente detalharei. Postulando sete pontos, Uribe, Abramovitz e Polo -com a presença de Bonsiepe- estabeleceram alvos de reivindicação profissional e alguns de interesse cultural; propósitos práticos para a fundação da futura associação como canal de comunicação entre os profissionais da região e, por fim, começar a determinar os caminhos de ação.

[...] los representantes de Argentina, Brasil y Colombia proponen la creación de una Asociación Latinoamericana de Diseño Industrial ALADI- con el fin de fortalecer la cooperación técnica entre los países en desarrollo. Dichos participantes darán los pasos necesarios para institucionalizar esta propuesta en sus respectivos países, invitando a los miembros de otras naciones latinoamericanas a tomar parte en estas atividades (Abramovitz, J. et, al., 1980, p. 18). ${ }^{6}$

\section{Sensibilização nacional}

Cinco meses depois, em junho de 1979, Jaime Gutiérrez, Danilo Rey, Luis Carlos Lega, Jesús Gámez, Fernando Prieto, Julio Ayala, Rómulo Polo, Francisco Ramírez, Billy Escobar, Rodrigo Samper e Hernán Lozano, reuniram-se em Bogotá, Colômbia com o

\footnotetext{
${ }^{6}$ Rey (2009) afirma que naquele processo esteve presente o mexicano Alejandro Lazo. Contudo no listado de participantes ao evento na Índia o seu nome não aparece. De igual forma, nem nas memórias de Abramovitz nem nas de Rómulo Polo se menciona ao Lazo naquele momento.
} 
propósito de discutir ideias relacionadas ao processo de criação de uma associação latino-americana. ${ }^{7}$

Dessa reunião, esses onze colombianos redigiram uma declaração na qual propuseram dois ou três pontos, relacionados com a estrutura organizativa da futura associação. No documento sugeriram que a ALADI deveria operar como um órgão representativo misto -de pessoas e instituições-, decisão que embasou as categorias de membros recomendadas na posterior reunião do México -em outubro 1979- e finalmente estabelecidos nos estatutos fundacionais na Colômbia em 1980. Igual acontecerá com o caráter organizativo. Na declaração, os colombianos propuseram que a ALADI funcionasse com períodos rotativos, fazendo dela uma entidade representativa dos interesses das associações nacionais. Esse mesmo preceito foi proposto pela organização argentina que criava nesse momento o CADI -Comité Argentino de Diseño Industrial (Rey, 2009)-. A recomendação final da declaração colombiana foi a de estimular a participação de designers latino-americanos no Congresso do ICSID a ser realizado no México e estabelecer, como região, um posicionamento claro para aquele congresso.

Essas recomendações foram feitas com base no reconhecimento da importância da existência de uma associação de caráter continental, que permitisse a comunicação e estimulasse o intercâmbio entre os designers latino-americanos para compartilhar experiências, fortalecer a partir daí o debate do campo profissional, aparar as arestas sobre o entendimento do papel social do designer, delimitar as suas fronteiras com outros campos profissionais, entender como proteger legalmente a sua atividade profissional e incentivar o fortalecimento acadêmico da disciplina. Um discurso impregnado de claras reivindicações profissionais.

Contudo, as reinvindicações não param por aí. Como será claramente visível nos objetivos políticos da ALADI, aprovados na fundação em Bogotá em 1980, os membros fundadores estavam mergulhados em um debate cultural abrangendo a compreensão do

\footnotetext{
${ }^{7}$ Para esse momento, a maioria deles já eram membros da Asociación Colombiana de Diseñadores (ACD), criada em Bogotá, em 1976. Existe um vindicado antecedente para a conformação de um corpo regional de designers no interior da ACD. Segundo documento entregue pela associação colombiana para o primeiro congresso da ALADI, em 1972 Daniel Gómez tinha proposto a criação de uma entidade dessas proporções. O contexto dessa proposta é uma reunião dos designers 'americanos' no México (Secretaria de organización, 1979). Pelo que posso perceber e a pesar da antecedência, o espirito dessa iniciativa era vinculativo, no sentido de se aderir nesse casso no corpo norte-americano, e não autonomista, como efetivamente governa o sentido da ALADI.
} 
Design Industrial como tecnologia e dela como garantia para romper os anéis da cadeia da dependência com o Centro... como o caminho para a liberdade de "nossos povos". Uma clara reivindicação cultural de mãos dadas com a reivindicação profissional. Ou que lhe daria a base?

Essas duas ideias estão expostas na declaração dos colombianos como “considerandos”, e são postulados que vão chegar claros no México em outubro de 1979. Ao que parece, na reunião na Índia no princípio daquele ano se tinha acordado "que el próximo mes de agosto [1979] se realizará en Rio de Janeiro una reunión preparativa para la organización del ALADI" (Gutiérrez, et al., 1980, p. 19) pelo que pensaria que essas duas ideias na declaração colombiana -retomadas do primeiríssimo escrito Documento de Intención, em Interdesign 78 que tratarei mais a frente-, tentavam alimentar os preparativos latino-americanos para Congresso do ICSID a ser realizado. Ao final, os colombianos estavam determinados sobre a necessidade dos designers da região chegarem ao México com uma posição comum, "con el presupuesto mínimo de obtener representación latinoamericana en el Consejo Directivo de ICSID” (Gutiérrez, et al., 1980, p. 19).

\section{0 pacto das catacumbas}

1.

Entre 14 e 19 de outubro de 1979, deu-se o segundo momento mais importante na consolidação da ALADI, o $11^{\text { }}$ Congresso do ICSID organizado no México (ICSID, 1979). ${ }^{8}$ Esse congresso contou com palestras centrais, ministradas por integrantes do conselho internacional, como Ettore Sotsass, Tomás Maldonado, Gui Bonsiepe, entre outros. Igualmente foi organizado um grupo de mesas de trabalho e uma exposição de Design Industrial internacional. Vale a pena revisar os detalhes que apresenta Messell (2016) sobre esse evento.

Aproveitando que o ICSID programou seu congresso bienal no México -o primeiro e até o momento o único na América Latina- e, quem sabe, pelos temas a trabalhar,

\footnotetext{
${ }^{8}$ Os congressos anteriores tiveram local na Suécia (1959), Itália (1961), França (1963), Áustria (1965), Canadá (1967), Inglaterra (1969), Espanha (1971), Japão (1973), Rússia (1975) e Irlanda (1977) (ICSID, 1979). É bom lembrar que o ICSID foi criado em 1957 na Inglaterra, em uma reunião de designers representantes da Dinamarca, França, Alemanha Ocidental, Itália, Noruega, Suécia, Reino Unido e Estados Unidos (Pulos, 1988, p. 216). Como provocação, datas, locais e temas próximos do Congresso pela Liberdade Cultural, desenhado pelos Estados Unidos com a missão de "afastar a intelectualidade da Europa Ocidental [do] marxismo e o comunismo" (Saunders, 2008, p. 13).
} 
vários designers da região sentiram-se convocados para assistir. Desse modo, o grupo colombiano levou o manifesto de apoio à ideia da ALADI e intercedeu para que a organização do congresso aceitasse uma sessão na qual os assistentes latino-americanos fossem convocados para se reunir de forma paralela. 0 propósito era apresentar a proposta de formação da associação, que vinha se construindo desde novembro de 1978, ou seja, onze meses antes.

Aquela sessão foi aberta ao final da programação do dia 15 de outubro, na qual 40 pessoas assistiram à apresentação da proposta de criação de uma entidade que representasse os interesses dos designers industriais da região. Depois de voltar do México, em seu texto publicado no Jornal da APDINS/RJ, Joaquim Redig escreve que a reunião teve

[...] como motivação básica cuidar dos interesses dos designers latinoamericanos, que possuem uma série de interesses comuns justamente por suas características geográficas e culturais comuns, distintas das características dos países europeus, tradicionalmente representados no ICSID (Redig, 1980, p. 4).

Segundo o documento assinado naquela ocasião, os expoentes apresentaram tanto as ideias principais do Documento de Intención, redigido e assinado por nove latinoamericanos assistentes do workshop Interdesign de 1978, como as ideias discutidas na reunião da Índia entre Basílio Uribe, José Abramovitz e Rómulo Polo em janeiro de 1979.

A partir dessa apresentação no México, e das grandes virtudes entendidas na ideia de criar a ALADI, concluiu-se que era necessário pensar na ALADI como uma organização de indivíduos e instituições; uma organização dinâmica, fórum de ideias e instrumento de influência (ALADI, 1980b, p. 20). A partir dessa reunião foi criada uma Comisión de Redacción que se reuniria para ajustar algumas definições, principalmente estruturais, e apresentar um novo o documento dois dias depois, em 17 de outubro.

2.

Aquela comissão foi formada por Ana Maria de Moraes do Brasil, Nelly Toledo de Porto Rico, Claudio Rodríguez do México, Roberto Napoli da Argentina, Iván Espín de Cuba, Rómulo Polo da Colômbia, Rodrigo Walker do Chile, Oscar Pamio, italiano domiciliado na Costa Rica e Gui Bonsiepe, alemão pela Argentina. Eles estudaram os três documentos: o Documento de Intención redigido no México em Interdesign 78, o discutido na reunião da Índia, assim como o proposto na Declaración de los Diseñadores 
Colombianos de junho de 1979. Refinaram vários detalhes conceituais determinando os caminhos para as próximas ações. No dia 17, a comissão apresentou um novo documento que determinava que

[...] ALADI pretende ser un organismo regional representativo en el ámbito de Diseño Industrial en sus diferentes manifestaciones: Proyecto (práctica profesional) [sic]; enseñanza; promoción; investigación; difusión; administración (ALADI, 1980b, p. 20).

Aquela comissão estabeleceu um rascunho de objetivos gerais -dez, no total- que giravam em torno de cinco ou seis eixos de atividade. Um de comunicação e logística, com ênfase na ideia de troca constante de experiências entre os designers latinoamericanos; outro de institucionalização da profissão, na luta pelo campo; outro relativo ao desenvolvimento e fortalecimento acadêmico; outro procurando a assistência governamental e um de promoção do Design Industrial. Estes sendo muito próximos do grupo de objetivos definidos na fundação da ALADI em Bogotá um ano depois, em 1980.

Procurando definir ações concretas, ao final, a comissão propôs a formação de um Comité Coordinador Provisorio com duração de doze meses, encarregado de organizar várias tarefas nos seguintes seis ou nove meses. A comissão apresentou a candidatura de alguns colombianos para formar o Comité Coordinador Provisorio. Dado os acontecimentos seguintes, fica claro que a candidatura foi aprovada

[...] foi o que aconteceu [...] com os designers latino-americanos que, reunindo-se paralelamente ao Congresso da ICSID XI, em suas dependências, redigiram um Documento (para orientação) e formaram uma Comissão (para dar andamento ao assunto), visando iniciar o processo de criação de uma Associação Latino-americana de Desenho Industrial (ALADI) (Redig, 1980, p. 4).

A proposta foi assinada por 66 pessoas, representantes de nove ou dez países latino-americanos. 
Assinantes no XI Congresso do ICSID no México 1979

\begin{tabular}{|c|c|c|}
\hline Ricardo Blanco & Magdalena de las Heras & Jorge Vila Ortíz \\
\hline Francisco J. Santos Z. & Jose Luis Alegria & Carlos E. Kohler \\
\hline Basílio Uribe & Miguel Marin P. & Luis Fernando Zapata \\
\hline Roberto Napoli & Dolores Ortiz & Juan Gómez \\
\hline Carlos Chávez & Jesus López Veloz & Rómulo Polo \\
\hline Carlos Carillo & Enrique Camargo & Ricardo R. G. de Tarsio \\
\hline Francisco Garcia & Andrés Hayaux du Tilly & Olicio C. Pelosi \\
\hline Enrique Roman & Adriana Canales & Franca Rosi \\
\hline Walter Oehler de la Mora & Enrique Camargo $\mathrm{C}$. & Oscar Pamio \\
\hline Carlos M. Caballero L & Miguel A. Martínez & Luis E. Arroyave \\
\hline Francisco Jose Soto & Fco. Manuel Lazo & Joaquim Redig \\
\hline Carlos Daniel Soto & Guillermo Sicard & Iván Espín \\
\hline Jose Luis Berrueta & Jesús Virchez & Ana Maria de Morais \\
\hline Guadalupe Gonzalez & Anne E. Madrid & Gui Bonsiepe \\
\hline Luis Romero Regús & Raúl Eguia Malo & Rodrigo Walker \\
\hline Luis Sierra & Jairo R. Acero & Francisco Masjuan \\
\hline Sergio Sotelo Aren & Gabriel Bernal Ruiz & Luz María Gómez S. \\
\hline Felix Fernández G. & Ingo Werk & José Antonio Gallardo \\
\hline Patricia Guizar & Jose M. Rodríguez & M. M. de las Heras \\
\hline Luis Soto Walls & Sergio Rivera & Manuel Ignacio Mier \\
\hline Carlos R. Cadena & Michael Weiss & Jaime González Yapor \\
\hline Edgar Peregrina & Fernando Shultz & Cecilia Durán \\
\hline
\end{tabular}

Tabela 1. Assinantes da proposta de conformação da ALADI no $11^{\text {o }}$ Congresso do ICSID na Cidade do México em outubro de 1979. Fonte: (ALADI, 1980b, p. 22). 


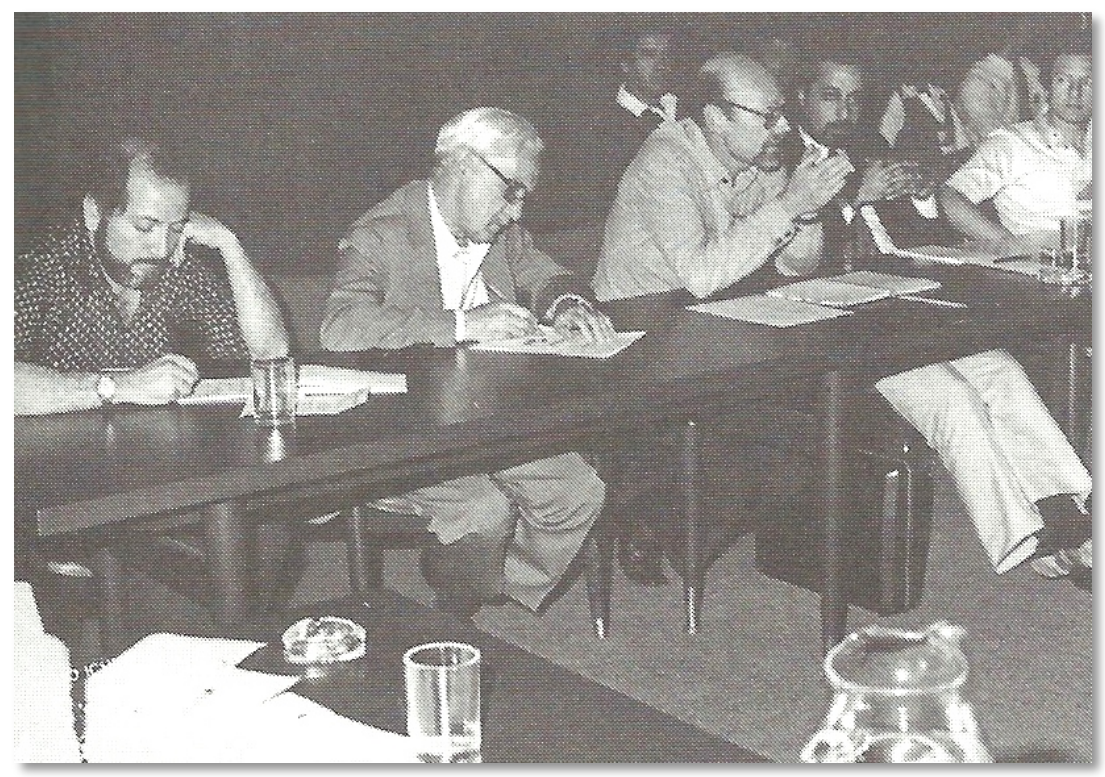

Figura 1. Apresentação da proposta da ALADI

11ํ Congresso ICSID, Cidade do México, outubro de 1979.

De esquerda a direita: Rómulo Polo (Col.), Basílio Uribe (Arg.),

Gui Bonsiepe (Ale.-Arg.), Roberto Napoli (Arg.) e Mario Mariño (Arg.)

Fotografia tomada do livro Crónicas del Diseño Industrial en la Argentina de Ricardo Blanco (2005).

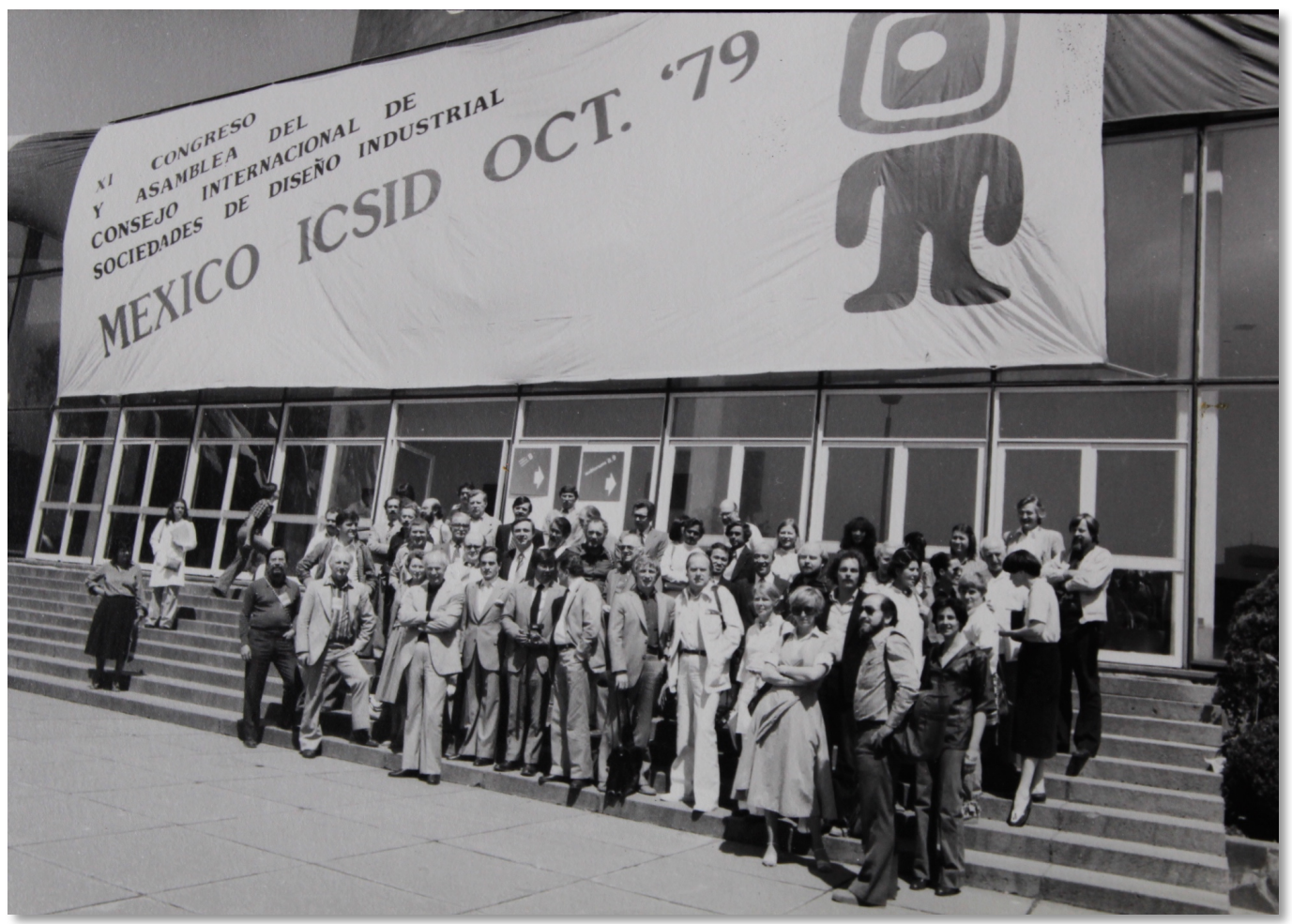

Figura 2. Assistentes no 11 Congresso do ICSID

Fotografia do Acervo Pessoal de Claudio Rodríguez na Cidade do México (APCR). 


\section{Medellín, 1980}

Oito meses depois dessa reunião no México e cinco meses antes da criação da associação, o Primer Simposio Internacional de Diseño de Interiores foi realizado em Medellín na Colômbia entre 4 e 7 de junho de 1980.

Grandes nomes do design mundial foram convidados para esse evento, dos quais estiveram presentes como conferencistas Ilmari Tapiovara da Finlândia, Jesús Gámez da Colômbia, Gajanan Upadhyaya da Índia, Jaime Gutiérrez e Rogelio Salmona da Colômbia, Gui Bonsiepe da Alemanha, Mario Bellini da Itália, Gae Aulente da Itália, Oliver Mourgue da França, George Nelson e Arthur Pulos dos Estados Unidos, esse último presidente do ICSID naquele momento, e Theo Crosby da África do Sul (Ramírez, 1980).

Aproveitando o momento do simpósio, a equipe organizadora da ALADI'80 (ALADI/Colombia) convocou uma reunião informativa sobre o processo de constituição da associação. Aquela reunião teve presença de delegados de quatro países: Argentina, representada por Ricardo Blanco e Gui Bonsiepe; Oscar Pamio da Costa Rica; Cláudio Rodríguez, Sergio Rivera, Oscar Salinas e Alejandro Lazo do México e Jaime Gutiérrez, Jesús Gámez, Rómulo Polo, Hernán Lozano, Mauricio Olarte, Guillermo Sicard, Rodrigo Fernández, Jairo Acero, Fernando Prieto e Luis F. Zapata da Colômbia

[...] El grupo coordinador de ALADI en Colombia informó sobre la situación actual del Programa de Trabajo preparatório de la reunión que deberá llevarse a cabo en Bogotá, de acuerdo a lo convenido por los firmantes del documento de México "ICSID 1979" (Polo et al, 1980a, p. 22).

\section{Um amanhecer de vinte quatro meses}

Como mencionei anteriormente, entre os dias 6 e 13 de novembro de 1980, ocorreu a assembleia de fundação da ALADI, assim como seu primeiro congresso. No capítulo seguinte farei um mergulho na estrutura do acontecido em Bogotá 1980, abordando o contexto histórico da região assim como as heranças e ideias compartilhadas por um amplo grupo de intelectuais latino-americanos. Por enquanto, posso dizer que essas ideias correspondem a um desdobramento do discurso que veio se ajustando desde que a ALADI foi pensada pela primeira vez. 
O processo de configuração da ALADI durou dois anos, e teve pelo menos cinco momentos decisivos. Dependendo do critério usado, esses momentos podem ser agrupados de várias maneiras. Pode-se crer que estão organizados em dois grupos principais. 0 menor grupo seria aquele das reuniões nacionais, que, dado que são motores da ação local, sua transcendência regional é subsequente ou subsidiaria, como as reuniões de Bogotá em junho de 1979, Medellín em 7 de junho de 1980 e Buenos Aires em 10 de junho de 1980 nessa ordem de importância conceitual e impacto internacional. A primeira foi base da existência de um manifesto que alimentou a maior reunião prévia da fundação -11ํㅡㄹ Congresso do ICSID no México-; a segunda, em Medellín, um evento informativo que aproveita a sombra de um evento maior, estimulando e, até mesmo, evocando desde esse momento a formação da ALADI; a terceira, uma reunião de alcance nacional e de relativa importância para a institucionalização do design argentino

[...] Bonsiepe junto con Roberto Napoli, representante de la Argentina ante ALADI, convocan a 7 entidades del país relacionadas con el diseño industrial, a una reunión que se realizaria el 10 de junio [3 dias após a reunião em Medellín] en la sede del CIDI, y que sería la primera de una larga serie donde se conformaría el CADI, Comité Argentino de Diseño Industrial, y se trazarían los lineamientos de la propuestas y politicas a seguir ante ALADI (Rey, 2009, p. 401). ${ }^{9}$

O segundo grupo estaria composto por outros quatro momentos (ver tabela 2): Bogotá Colômbia em 1980 (fundação), Cidade de México em 1979 (11ํㅡㅁongresso do ICSID), Bombaim Índia em 1979 (UNIDO-ICSID) e Valle de Bravo no México em 1978 (Interdesign 78).

Poderia-se considerar na reunião em Bogotá em novembro de 1980 como o momento de concreção, o que lhe outorga uma importância evidente -para muitos será o momento mais importante-. Visto dessa forma talvez de diacronia-transcendência, a apresentação da ideia da ALADI no 11ํ Congresso do ICSID seria a segunda mais importante: o documento produzido foi assinado por 66 participantes, provenientes de sete países da América Latina (ALADI, 1980b). Se por dar início formal ao projeto ALADI,

\footnotetext{
${ }^{9}$ Nesse grupo estariam também aquelas reuniões que não consegui saber se efetivamente aconteceram, como a suposta reunião realizada no Rio de Janeiro em agosto de 1979, mencionada como programada no manifesto colombiano. Como no caso argentino, o mais provável é que esse tipo de reuniões se produziram tanto no México, como na Costa Rica logo depois do retorno ao país daquela reunião espontânea de Medellín. A mesma coisa deve ter acontecido no Brasil, Equador, Porto Rico, Guatemala e Cuba ao ser confirmada a realização da primeira ALADI.
} 
a sua criação pressupõe a maior importância, foi no México em 1979, naquele Congresso do ICSID, que o primeiro rascunho se espalhou, obtendo um apoio abrangente na região, não só alcançando os ouvidos de futuros adeptos mas também das diretivas do ICSID. ${ }^{10}$

De acordo com essa forma de análise, o terceiro item em importância seria, na verdade, aquele em que os primeiros rascunhos seriam aprimorados e as tarefas de sensibilização estabelecidas - provavelmente a maior conquista da reunião em Bombaim entre Abramovitz, Polo e Uribe-. Por último ficaria, então, o rascunho e o nascimento da ideia em Valle de Bravo, México, no workshop Interdesign 78. Essa ordem responderia a um olhar quase positivista e mais ou menos fácil no sentido de privilegiar o critério da diacronia.

Para mim a ordem é exatamente a oposta, entendendo a criação da ALADI -Bogotá 1980 - como o quarto momento em ordem de importância. Essa reunião foi produto de um processo, cujas etapas são importantíssimas para explicar o seu nascimento, e cuja ideia inicial é uma motivação com tal força, tal grau de paixão, determinação e convicção dos atores envolvidos, que resulta em suficiente coragem para levar a cabo um processo gestacional de 24 meses na extensão geográfica, política e econômica da região. Com claridade, uma evidente ação racional embasada nas maneiras de olhar o mundo, para fazer apologia de Weber (2008) que por sua vez transparece o circuito de um tipo de ideias bem definidas entre determinados tipos de intelectuais latino-americanos. Todo um projeto. Toda uma genuína construção. Os traços de uma comunidade interpretativa no sentido exposto por Stanley Fish (1980). ${ }^{11}$

\footnotetext{
${ }^{10}$ Polo lembra que na reunião em Medellín, Arthur Pulos procurou convencê-lo de que afiliara a ALADI no ICSID. Polo seria presidente fundador da ALADI cinco meses depois disso, Pulos já era o presidente número doze do ICSID nesse momento "Yo le decía: vea, necesitamos una cosa propia, vital, independiente [JB: ¿Y qué le argumentaba él?]... no pues... la trayectoria del ICSID que todos los famosos están ahí. Y pues tiene capacidad... pero yo lo que veía era subordinación" (Polo, 2014a). Pulos já tinha uma clara leitura do que significava ALADI "we sense the rise of regionalism, sometimes more politically motivated really than product motivated. The Latin American, a number of Latin American countries have formed something called [ALADI] [sic], which is sort of anti developed countries, you know" (Pulos, 1980 e 1982).

${ }^{11}$ As ideias de Weber sobre a paixão são esclarecedoras para explicar as motivações e as ações dos seres humanos, tanto no ofício do científico quanto do artista. A partir dela, Weber afirma que o ser humano se faz perguntas e reflete sobre os diferentes fenômenos ao seu redor, como caminho para a criação 'do extraordinário' (Weber, 2007).
} 


\begin{tabular}{|c|c|c|c|}
\hline $\begin{array}{c}\# \\
\text { Mês }\end{array}$ & Data & Evento & $\begin{array}{c}\text { Q. } \\
\text { Meses } \\
\end{array}$ \\
\hline & $16-30$ nov/1978 & Interdesign 78 (Valle de Bravo, México) / Inicio & \\
\hline 1 & $\mathrm{dez} / 78$ & & \\
\hline 2 & $14-24$ jan/1979 & UNIDO-ICSID Meeting (Bombaim, Índia) / Reunião 1 & \\
\hline 3 & $\mathrm{fev} / 79$ & & \\
\hline 4 & $\operatorname{mar} / 79$ & & \\
\hline 5 & abr/79 & & 5 \\
\hline 6 & mai/79 & & \\
\hline 7 & jun/1979 & Declaração dos designers colombianos (Bogotá, Colômbia) / Reunião 2 & \\
\hline 8 & $\mathrm{jul} / 79$ & & \\
\hline 9 & ago/79 & & \\
\hline 10 & set/79 & & \\
\hline 11 & $14-19$ out $/ 1979$ & XI Congresso do ICSID (México D.F, México.) / Reunião 3 & \\
\hline 12 & nov/79 & & \\
\hline 13 & $\operatorname{dez} / 79$ & & \\
\hline 14 & $\mathrm{jan} / 80$ & & \\
\hline 15 & $\mathrm{fev} / 80$ & & 0 \\
\hline 16 & $\operatorname{mar} / 80$ & & \\
\hline 17 & $\mathrm{abr} / 80$ & & \\
\hline 18 & mai/80 & & \\
\hline 19 & 4-7 jun/1980 & 1er. Simp. Int. de Dis. de Interiores (Medellín, Colômbia) / Reunião 4 & \\
\hline 20 & jul/80 & & \\
\hline 21 & ago/80 & & \\
\hline 22 & set/80 & & 5 \\
\hline 23 & out/80 & & \\
\hline 24 & $6-13$ nov/1980 & Fundação da ALADI (Bogotá e Santandercito, Colômbia) & \\
\hline
\end{tabular}

Tabela 2. Cronograma general prévio à fundação da ALADI.

Na tabela podem se ver os seis momentos mais importantes no processo de fundação, incluindo o primeiro encontro dos designers latino-americanos no Interdesign 78 do México. Podem-se ressaltar dois grupos por cor: um, as reuniões locais (mês 7 e 19); outro, as reuniões mais 'internacionais' (2,11 e 24). 


\author{
Não, brief não
}

[...] Surge sin embargo la pregunta ¿Se justifican los diseñadores en una sociedad que no tiene posibilidades de diseñar su entorno (objetos y medio ambiente); es decir, que no construye ese entorno a partir de sus propias necesidades, sino que se ve obligado a adoptar modelos que le vienen del exterior?. Cabe preguntar ¿Cual será el rol del diseñador en una sociedad dependiente tecnológica y culturalmente? (Robles, 1978, p. 1).

\title{
Uma estrutura para a interação
}

Entre os dias 16 e 30 de novembro de 1978 foi realizado o $11^{\text {o }}$ Workshop Interdesign do ICSID no México, com o título "Alternative Energy Sources: Wind and Solar Energy for Use in Rural Areas in Mexico". ${ }^{12} 0$ workshop foi organizado pelo ICSID e o CODIGRAM (Colegio de Diseñadores Industriales e Gráficos de México), com o apoio de algumas organizações públicas e de designers do país e patrocinado pela UNIDO. Interdesign reuniu vários profissionais de design de várias partes do mundo. ${ }^{13}$

Segundo lembra Luiz Blank (2014), assistente brasileiro, entre a quinta-feira 16 de novembro e a segunda-feira dia 20, o grupo participante no evento recebeu algumas aulas sobre assuntos técnicos ministradas por especialistas mexicanos conhecedores do

\footnotetext{
$12 \mathrm{O}$ evento teve a Cidade do México como centro logístico na sua primeira parte (os primeiros três ou quatro dias). Dentro do plano de trabalho esteve incluída San Miguel Tzinacapan no estado de Puebla (uns $230 \mathrm{~km}$ ao nordeste da Cidade do México), onde foi realizado um 'trabalho de campo' em uma comunidade indígena, assim como Valle de Bravo (uma povoação uns $30 \mathrm{~km}$ ao este da Cidade do México), que serviu como base do trabalho do workshop durante dez dias ( 21 a 30 de novembro).

13 Segundo a lista de participantes, além dos membros do ICSID, Interdesign 78 teve assistência de dois representantes da Austrália, um da Áustria, um da Alemanha, um da Finlândia, um da Índia, um da Inglaterra, três dos Estados Unidos, dois da Iugoslávia, dois do Brasil, um da Argentina, um da Colômbia, dois do Salvador, uma do Paraguai, um do Peru e nove do México. Um total de 29. Excetuando os mexicanos, assistentes pela CODIGRAM, os latino-americanos presentes foram registrados como assistentes pela UNIDO, enquanto os norte-americanos, europeus e o indiano estavam sendo apoiados pelo ICSID: 12 dos 29 (CODIGRAM et al., 1978a). Polo lembra que, além disso, no workshop em Valle de Bravo, também teve a presença de vários estudantes que trabalhavam como assistentes de design (Polo, 2014b).
} 
tema das energias alternativas e visitou as comunidades rurais que seriam intervindas, isso último em San Miguel de Tzinacapan. ${ }^{14}$

Da terça-feira, dia 21, à quarta-feira, dia 29 de novembro, o grupo parece ter-se reunido para desenvolver o trabalho do workshop. 0 dia 30 foi dedicado à movimentação do pessoal, desde o local de trabalho em Valle de Bravo até a Cidade do México (CODIGRAM et al., 1978b).

Tanto Luiz Blank do Brasil quanto Rómulo Polo da Colômbia , dois dos assistentes latino-americanos do Interdesign 78 e fundadores da ideia da ALADI, lembram que uma parte do workshop foi realizada nas instalações de um convento isolado. Dada a agenda feita pela organização do evento, daquela terça-feira dia 21 até o dia 29, os assistentes conviveram em jornadas intensivas de trabalho com base em uma rígida agenda, comparável com a vida monástica. Com exceção dos dias 21 e 26, assim como do dia 30, as jornadas começaram às 8 horas, podendo terminar as 23 horas em uma faixa chamada "presentation"15

[...] The country home of a religious congregation was rented, served by nuns, which offered several advantages for this stage of the work: it allowed intensive work and housing for all participants and advisors. The distance from Mexico City helped concentration in the work and, however, allowed a pleasant and interesting enviroment for foreign participants (Martínez \& Gallardo, 1978, p. 14).

A menção desse detalhe é importante por duas razões que estudarei mais adiante. A primeira tem caráter anedótico. É possível que esse formato de reunião inspire práticas futuras da ALADI. Com a exceção de Cuba, as assembleias aconteceram em locais afastados dos centros urbanos nos quais eram realizados os congressos e eram desenvolvidas em 'jornadas monásticas'. Abordarei detalhes sobre congressos e assembleias da ALADI nos capítulos seguintes. ${ }^{16}$

\footnotetext{
${ }^{14}$ Blank -designer formado pela ESDI nos anos 1960- assistiu ao evento como membro da Secretaria de Tecnologia Industrial do Ministério da Industria e Comércio do governo brasileiro, a mesma instituição pela qual viajou José Abramovitz àquela reunião na Índia. Blank foi convidado diretamente pela organização do workshop e apoiado pela UNIDO.

150 dia 21 é o dia de chegada ao convento. No programa, seu itinerário começa às $18 \mathrm{~h} 30$ com uma aula sobre metodologia, seguido do jantar e da primeira sessão de apresentação. 0 dia 26 foi deixado para turismo: era domingo. Já mencionei que o dia 30 o grupo tomou o café da manhã e viajou para Cidade do México, onde, depois do almoço, foi feito o encerramento oficial do Interdesign às $17 \mathrm{~h} 30$.

${ }^{16}$ Somado a mais outros elementos, esse fato pode dar sentido àquela ideia expressada por Polo, segundo a qual, os fundadores de ALADI estavam procurando ter um ICSID latino-americano “...teníamos un sentimiento anti-ICSID sobre todo en la parte inicial, o, sino era anti, era por lo menos precavido con respecto a la relación con el ICSID. Nosotros queríamos crear un ICSID Latinoamericano. Esa era la visión..." (Polo, 2014).
} 
A segunda razão é que a estrutura proposta demostra um rigor no trabalho e uma quantidade de tempo para a interação dos assistentes do grupo. Ao transluz de aquilo que estavam fazendo, das coincidências -principalmente entre eles- e sobretudo das diferenças em relação ao proposto pela organização do evento, isso vai ser importante na compreensão das condições que permitem pensar em uma ideia como a ALADI.

\section{Design e tecnologia adequada}

1.

Poderia pensar que o Interdesign 78 foi dividido em quatro partes ou momentos. A primeira parte, entre os dias 16 e 21 de novembro -de quinta a segunda-feira, com recesso no dia 20-, foi composta por aulas sobre o tema central do workshop na Cidade do México. Essas aulas foram ministradas por engenheiros, pertencentes ao Instituto de Investigaciones Eléctricas de México, e foram direcionadas para a compreensão dos princípios técnicos envolvidos nos processos do uso de energias alternativas. ${ }^{17}$

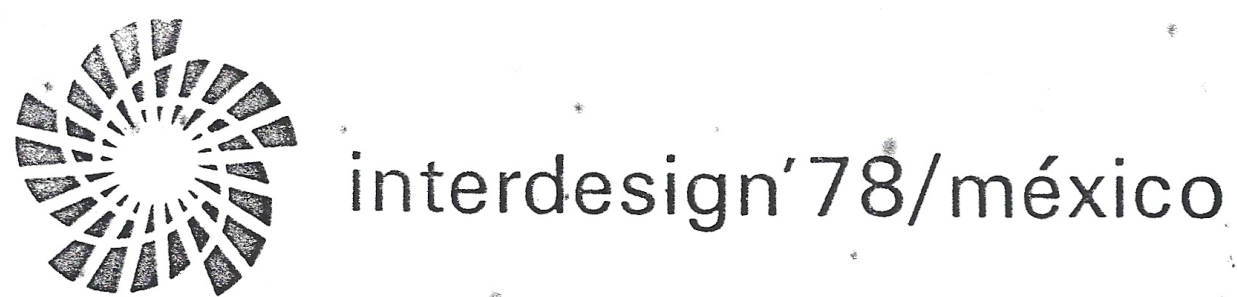

Figura 3. Programação visual Interdesign 78

Xerox do encabeçado da carta de benvinda que a organização aparentemente entregou com o material didático do workshop (CODIGRAM et al., 1978d).

Acervo Pessoal Luiz Blank no Rio de Janeiro (APLB).

A aula de teoria da tecnologia adequada para o desenvolvimento parece ter sido ministrada a partir de um texto que aparentemente circulou dentro do workshop como texto de apoio. Esse texto, intitulado Adequate Technology for Ecodevelopment, foi escrito por Vicente Sánchez em agosto de 1978, ou seja, dois meses antes do Interdesign (Sánchez, 1978).18 Esse documento está estruturado em seis partes, nas quais são

\footnotetext{
17 Algumas dessas aulas foram: 1) Fermentación aeróbica, 2) Diseño y construcción de sistemas de bombeo de agua de bajo costo movidos por la energía del viento, por J. Nicolás Puga e 3) Sistemas pasivos para calentamiento de agua con energía solar, por E. Caldera Muñoz (CODIGRAM et al., 1978c). Graças à generosidade de Luiz Blank, teve acesso ao material didático dessas sessões.

18 Vicente Sánchez foi embaixador do Chile em Nairóbi, assim como diretor do escritório latino-americano da PNUMA (Programa das Nações Unidas para o Meio Ambiente) criado em 1972.
} 
apresentados o conceito ecodevelopment, as suas ligações com a tecnologia, alguns exemplos em produção de energia, arquitetura, agricultura, pequena indústria e produção de alimentos em comunidades rurais do chamado “Terceiro Mundo".

Esse documento estabelece duas ou três grandes ideias que já eram parte da experiência profissional e das categorias de percepção de vários dos assistentes, como mostrarei daqui a pouco. Por uma parte, ele apresentava o princípio de ecodevelopment como um sistema no qual as dimensões econômicas do desenvolvimento são tão importantes quanto as naturais -no sentido dos recursos ambientais- e as sociais. 0 ecodevelopment era a compreensão dessas três esferas em igualdade de importância é o princípio fundamental da sua tese. Aí, a busca da qualidade de vida das povoações convertia-se no principal propósito do desenvolvimento, determinando algumas premissas. Por exemplo, a ideia de que a chamada "maximização da eficiência funcional" devia ser conquistada, a partir da precisa caraterização tanto dos recursos naturais quanto das variáveis sociais envolvidas em uma necessidade particular. E essa necessidade, além de real, devia conduzir ao melhoramento da qualidade de vida.

Outra premissa era o sentido de flexibilidade e critério no processo de planejamento de uma intervenção, ou seja, o respeito pelo contexto no qual aconteceria uma certa atividade de intervenção tecnológica. Uma quarta noção seria o estabelecimento de um sistema institucional, que permitiria a necessária participação democrática e representativa das comunidades, tentando respeitar o feito de que as pessoas devem intervir sobre as decisões do seu estilo de vida. Tanto para Sánchez como para a linha de argumentos nesse campo, o problema da tecnologia passava pelo dilema da sua importação ou da sua geração local, no fundo do qual estavam os estilos de vida e os paradigmas da povoação. Aí, ele chega a um problema fundamental: a transferência de tecnologia implica um problema muito maior do que o simples translado de equipamento

[...] it also highlights what is becoming a well-know tendency: "Let us extract the fossil fuels from the Third World and consume it in the capitalist countries. In Exchange, let us develop alternative sources of energy for the underdeveloped to be our markets. Beware! (Sánchez, 1978, p. 7).

2.

Nesse contexto, Sánchez apresenta alguns exemplos nos campos que já mencionei -energia, arquitetura, agricultura, pequena indústria e produção de alimentos-, a 
maioria deles, projetos implementados em território mexicano. Não é difícil inferir que para Sánchez a conquista dos ideais do ecodevelopment só seria possível se o projeto de intervenção tecnológica chegasse ao seu ideal da eficiência, o que quer dizer que o projeto seria condicionado pelos dados concretos e não ao contrário (Sánchez, 1978, p. 8).

Sánchez usa um estudo de caso como exemplo relacionando sucesso com aumento da qualidade de vida, ou seja, a solução de necessidades por meio do estudo dos recursos da povoação e o resgate da tecnologia indígena como mecanismo para resolvêla. ${ }^{19} \mathrm{O}$ diagnóstico sistêmico de uma necessidade real em um contexto particular que envolve o povoado na definição e na determinação do seu problema e da sua solução. Sempre supondo a compreensão do problema pelas pessoas envolvidas, sua situação econômica e os ecossistemas predominantes no contexto, assim como as suas respectivas relações. Em síntese, uma visão de sucesso que pressupõe o benefício das grandes massas a partir da sua participação na determinação e na resolução dos problemas. Esse entendimento de sucesso, em sentido ideológico, contrapõe a ideia de um desenvolvimento tecnológico descontextualizado, beneficiando minorias.

$\mathrm{Na}$ descrição de outro estudo de caso, Sánchez expõe um caso de fracasso ao descrever um projeto desenvolvido no México, em San Luis de la Paz, Estado de Guanajuato. Para Sánchez, a transferência da bomba de água operada por energia solar do que tratou aquele projeto-, reunia os problemas estruturais relacionados às relações tecnológicas entre países, o que ele assinala como impedimentos de um verdadeiro desenvolvimento ambiental. Segundo sua crítica, esse projeto agrupou a maior quantidade de males em relação ao princípio da tecnologia apropriada. ${ }^{20}$

Para Sánchez, o projeto de Guanajuato não gerou nenhum emprego local com o agravante de ter sido pensado a curto prazo. Embora grave, o primeiro não tem as implicações do segundo: a tecnologia importada não possibilitou a transferência de nenhum conhecimento, nem mesmo sequer o chamado know-how. De acordo com

${ }^{19}$ Chamado Ecotechniques for cattle-feeding and processing of subproducts, em Xoxocotla, agroindustria no estado de Morelos no México. O projeto foi desenvolvido pelo Instituto Tecnológico Agropecuario e o Instituto de Investigaciones Eléctricas (Sánchez, 1978, p. 9).

${ }^{20}$ Sánchez expõe que projetos tecnológicos devem respeitar uma espécie de protocolo: primeiro dar conta se o problema ou necessidade pode ser resolvido resgatando tecnologias próprias que podem ter sido abandonadas -sobretudo indígenas para o "Terceiro Mundo"-. Se não, avaliar a adaptação de antigas tecnologias do contexto mesmo. Se ainda persiste a necessidade, aí, e só aí, fazer uma apropriada seleção da tecnologia que vai ser importada. Tudo isso inserido no que chamou "criação endógena" (Sánchez, 1978, p. 4). 
Sánchez, essa situação colocou aquela povoação mexicana em um estado de dependência tecnológica em relação aos franceses que planejaram o sistema, impondo os seus prejuízos sobre o assunto e condicionando o contexto às variáveis tecnológicas. Foi engendrado o grande golem: a dependência tecnológica desse povoado mexicano, nessa situação, e o estabelecimento de um estilo de vida do que os povoadores não tiveram escolha. A dependência tecnológica como elo para a dependência cultural.

\section{3.}

Acompanhando o seguro debate que se desenvolveu em torno das ideias que estão no texto de Sánchez -sem dizer que o texto o estimulou- ${ }^{21}$, o workshop também incluiu pelo menos uma aula de metodologia do design que foi aparentemente ministrada por Derek Fuller Wrigley, um arquiteto inglês que morava na Austrália desde 1947.22

No material didático aparentemente elaborado por ele, o exercício de design gravita em torno da satisfação de uma necessidade, como se pode ver na Figura 4. Esse exercício é composto por uma série de passos que intendem a compreensão de enunciados maiores a partir de seu desmembramento -qualidades de uso, métodos e materiais disponíveis, intervalo de custos etc.- até as especificações requeridas pelo sistema que será projetado: tamanho do sistema, ferramentas, determinantes funcionais específicas etc. Esse desmembramento era assistido pelo preenchimento de uma tabela que acompanhava essa primeira folha. ${ }^{23}$

A proposta de Wrigley parecia terminar em uma tabela que avaliava aqueles requisitos e os ponderava em uma certa ordem de prioridade: desde o que ele chamou "vital”, passando por "important", até chegar ao "desirable" (Wrigley, 1978, p. 3). Um clássico modelo de ponderação de determinantes e requisitos, que estava reivindicando a primazia metodológica desde os anos 1960 em várias disciplinas projetuais, sobretudo

\footnotetext{
${ }^{21}$ Pelo que consegui estabelecer, o texto de Sánchez esteve dentro do material didático entregue pela organização do workshop. Porém, que ele esteja naquele pacote, não significa que tivesse sido trabalhado. 0 certo é que tais ideias estavam no ambiente, dado o tema do workshop e o olhar que vários assistentes já tinham sobre o papel do design e da tecnologia em contextos subdesenvolvidos. De fato, essas ideias faziam parte dos sentidos como era criticada a realidade em várias camadas de intelectuais latinoamericanos desde os anos 1940.

22 Wrigley nasceu na Inglaterra em 1924, tendo se formado como arquiteto em 1945, em Manchester University. Mudou-se para a Austrália em 1947, onde esteve envolvido na criação de corpos associativos como a IDCA (Industrial Design Council of Australia) em 1956. IDCA vai ser substituída pela ACD (Australia Design Council) em 1987.

23 O documento chamado "Design Method", assinado por Derek F. Wrigley, é o material didático da aula de quatro folhas numeradas: 1,2 , 2a e 3 .
} 
nas engenharias e mais tarde nos diversos autores do design. Na figura, a frase abaixo do ideograma que diz "good design is always the optimum result of the sum of the true needs of a particular set of circumstances", remete ao trabalho de Matchett intitulado "Control of thought in creative work", publicado em um jornal de engenharia em 1968, e dá grandes pistas sobre o que se debatia como papel do design em determinadas esferas profissionais na segunda metade dos anos 1970, em particular, o debate dentro do ICSID. Retomarei mais à frente. ${ }^{24}$

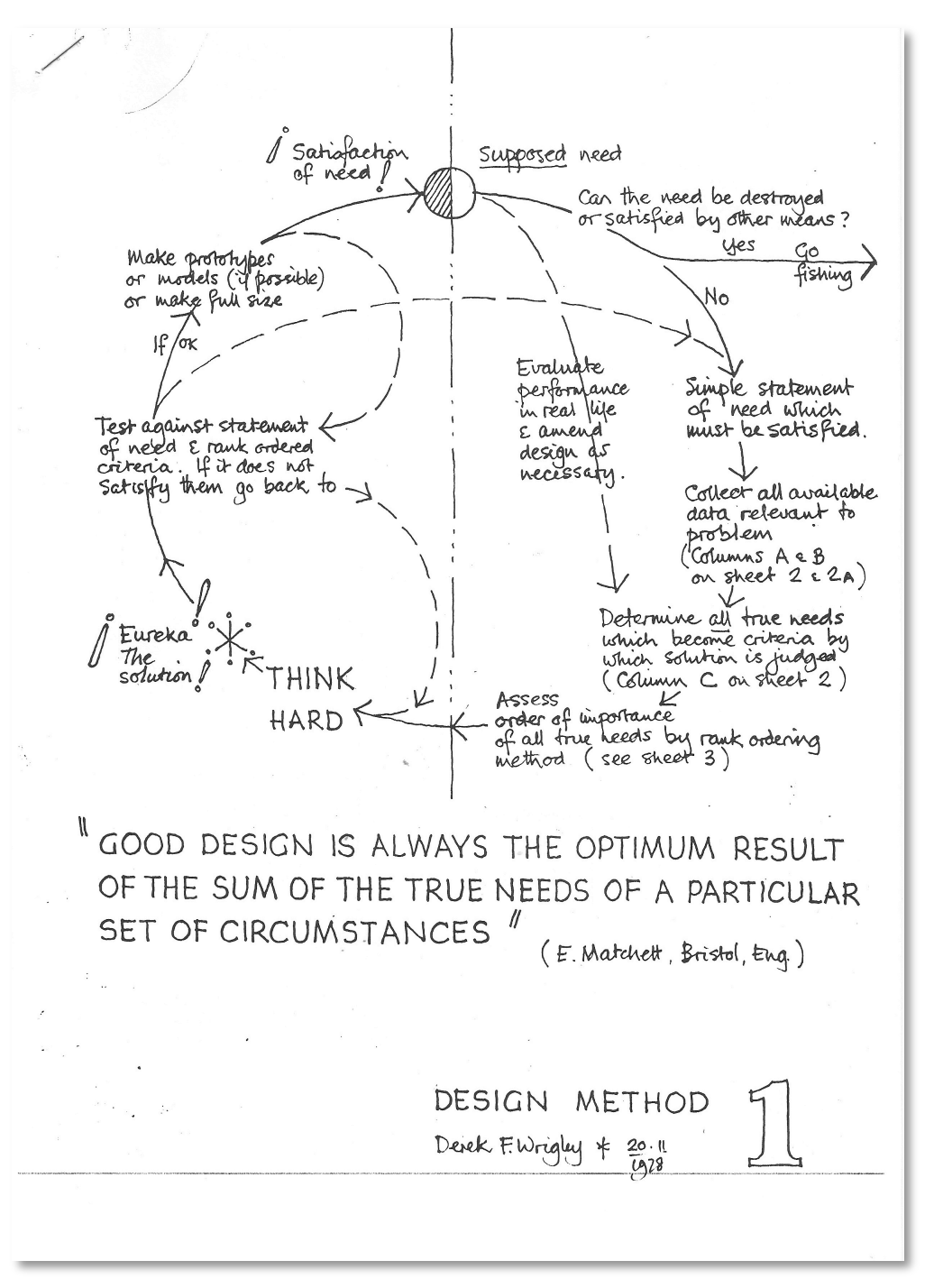

Figura 4. Primeira pagina do material didático Design Method (Wrigley, 1978).

Ministrada a terça-feira dia 21 de novembro (Martínez \& Gallardo, 1978).

Acervo Pessoal Luiz Blank, Rio de Janeiro (APLB).

\footnotetext{
${ }^{24}$ Pelo que consegui determinar, o nome do jornal no qual publicou Matchett era Chartered Mechanical Engineer, 14 (4) de 1968.
} 
4.

Algumas coisas quero deixar sublinhadas aqui, como ideias que serão trabalhadas mais à frente. De um lado, o conceito de ecodesenvolvimento apresentado pelo texto do Sánchez é uma reivindicação do local dos indivíduos na criação da sua própria realidade, assim como do respeito pelas condições nas quais se apresenta uma necessidade. 0 estilo de vida das pessoas que vão se ver envolvidas com a hipotética solução, assim como as linhas de administração de atividades produtivas que pudessem emergir na situação, deveriam ser definidas e determinadas com participação da comunidade.

Em segunda instância, é importante notar que para Sánchez -como representante de uma linha de pensamento respaldada pela ONU- existiam certas considerações a serem feitas em cada contexto, especialmente em relação aos sistemas tecnológicos. Esses passos deveriam estar o mais conscientes possível, para evitar os males da dependência tecnológica. Sánchez sabia que nas condições do jogo de poder estabelecidas pelas relações internacionais, esse era um caminho alcançar as "adequate tecnologies" (Sánchez, 1978, p. 4).

Por fim, é possível afirmar que para Sánchez, um diagnóstico correto de cada necessidade específica era imprescindível. 0 propósito último do melhoramento da vida das pessoas é possível se existe uma carência real, compreendida segundo as suas dimensões econômicas, sociais e naturais, em cuja decisão houvesse participação da comunidade. Se essas condições fossem levadas em conta, existiria a possibilidade que os sistemas tecnológicos criados pudessem responder à necessidade diagnosticada e atender à maioria da comunidade, sem utilidades segmentadas.

É preciso insistir em que esses postulados pressupõem um debate conceitual, e portanto político, acerca do uso da tecnologia e da intervenção social, que na região já tinha vários antecedentes. ${ }^{25} \mathrm{Um}$ debate que, no cenário daquele workshop, se pode compreender ainda maior do que o estritamente profissional, como apontarei mais à frente.

Pelas minhas conversas com Blank e Polo, tenho a ideia de que o documento escrito por Sánchez não foi estudado no workshop. Contudo, é preciso ressaltar que o

25 Um exemplo disso pode ser visto nas ideias do Camilo Torres durante os anos 1950. Em 1956, escreve: "el servicio del bien común, aun a costa del bien individual, no es sincero ni efectivo, sino se tratan de buscar los medios más aptos; el servicio del hombre no puede concebirse sin la ciencia y la técnica" (Aguilera, 2002, p. 70). Torres foi um bispo bogotano, professor e capelão da Universidad Nacional, pioneiro da Teologia da Libertação. 
fato de este texto estar incluído nos materiais do workshop, deixa-me pensar que o espírito do escrito pode recolher a orientação que os organizadores do evento pretendiam dar ao Interdesign. Lembremos que são os designers mexicanos da CODIGRAM os que organizam o evento, na sua grande quantidade -orientação temática e determinação logística-. O ICSID deu o respaldo institucional e aparentemente fez exigências metodológicas enquanto a UNIDO apoiou o projeto.

5.

Para acrescentar sentido, é importante mencionar que o texto de Sánchez estava acompanhado por um pequeno documento intitulado Intermediate Technology, produzido pelo famoso grupo inglês Intermediate Technology Development Group (ITDG, 1978). O documento é praticamente um catálogo de apresentação do grupo, no qual estavam descritos os objetivos do seu trabalho, sua filosofia etc. 0 interessante é que esse grupo foi fundado em 1965 pelo economista alemão Ernst Friedrich Schumacher, um dos pioneiros das ideias da tecnologia descentralizada, que seguramente servia como referência para Sánchez, assim como ao PNUMA -Programa das Nações Unidas para o Meio Ambiente-. ${ }^{26}$

Não sugiro que a existência desses textos no workshop tenham iluminado a forma de pensar dos assistentes. Por um lado, o texto de Sánchez é um rascunho que pega conceitos de um discurso multilateral, que supõe ser a institucionalização de uma ideia que vem sendo trabalhada com antecedência. A fundação do PNUMA em 1972 é, com certeza, o resultado de uma decisão de um grupo de pessoas já sensibilizadas com esses conceitos, pelo menos, desde o próprio Schumacher nos anos 1960. De outro modo, não quero cair no determinismo mais ou menos frequente no campo disciplinar dos designers, segundo o qual a existência de um texto explica que um grupo de pessoas percebem o mundo de acordo com as teses aí expostas, dado o fato de que estão escritas. Será que a embriaguez com o mito de origem, tão próximo ao espírito dos estudiosos do

\footnotetext{
26 E em segunda ou terceira instância aos designers industriais formados. Acho ilustrativa a relativização proposta pelo próprio Bonsiepe "The appropriate technology movement in the 80's was influenced by the writings of EF Schumacher, who wrote "Small is Beautiful" [publicado em 1972]. Increasingly the main protagonists of the movement were coming from the fields of engineering and economics. There were hardly any industrial designers as far as I know. Designers played a marginal role in these efforts to do something about design in what was at that time called developing countries" (Bonsiepe, 2002, p. 6). Tão ilustrativa quanto polêmica. Não é difícil encontrar as similaridades dessa corrente mencionada por Bonsiepe e o trabalho de Papanek formalmente exposto desde 1972. 0 próprio Margolin (2007) expõe tais ligações como base do trabalho ao interior do ICSID desde pelo menos 1973 com a criação do Group 4.
} 
design, pode explicar a ingenuidade que mora em tal determinismo? De que a existência de um livro implica inequivocamente na influência no pensamento de outros? Segue sendo mais ou menos ingênuo pensar que uma ideia chega ao seu estado de pureza naqueles que a lêem. Certas teses de alguns teóricos como Hall e Fish dão por superado tal redução (Fish, 1980; Hall, 2008). Em muitos dos casos do design, a existência de um texto impresso em realidade está confirmando apenas a circulação de ideias em formatos muito menos versados, deixando ver, entre tantas coisas, o sujeito que conseguiu ter acesso aos mecanismos de divulgação no cenário do capitalismo editorial.

No caso que discuto, as ideias que Sánchez defende, já haviam sido defendidas em publicações anteriores, como propostas maiores à hora de compreender postulados para o desenvolvimento, como aqueles propostos pela CEPAL para nossa região, ou aquelas que estão sendo apropriadas pela Arquitetura Moderna na América Latina, entre outras tantas. E são, para disser assim, ideias que fazem parte da maneira como vários grupos de intelectuais latino-americanos constroem sua crítica do desenvolvimento em seus países, pelo menos desde os anos 1950.

De fato, são parte das categorias de percepção já consolidadas em vários dos assistentes do Interdesign 78, graças a seus anos e cenários de formação e, sobretudo, em função dos vários anos de experiência acumulada. É possível que o texto de Sánchez tenha reavivado, organizado ou orientado as ideias que os latino-americanos traziam claras em suas mentes. Seguramente, o espírito do workshop alinhado com o discurso de Sánchez e de Schumacher, promoveu a identificação daquelas categorias em vários dos assistentes por causa dos debates sobre o tema, deixando na mesa perguntas e temas por discutir.

\section{Exotismo e identidade}

1.

A segunda parte do workshop -daquelas quatro que mencionei antes- aconteceu no mesmo período, entre 16 e 21 de novembro. Depois da realização das aulas técnicas, teóricas e metodológicas, o grupo fez uma visita a San Miguel de Tzinacapan, um povoado próximo de suas heranças indígenas -Nahuas-. 0 CODIGRAM propôs o local ao 
ICSID e, de acordo com Óscar Hagerman é ele quem propôs San Miguel ao CODIGRAM (Hagerman, 2016). ${ }^{27}$

Polo lembra que os participantes foram divididos em dois grupos: um foi da Cidade do México diretamente para Valle de Bravo e se enclausurou no convento reservado para o trabalho, enquanto o outro grupo foi para San Miguel para fazer uma certa observação da povoação. Após a visita, os dois grupos se reencontraram no convento (Polo, 2014b).

Segundo as lembranças de Blank, em San Miguel Tzinacapan, era necessária a presença de um tradutor já que os habitantes não falavam espanhol.

Quem observa com cuidado a folha 1 de Design Method, do Derek Wrigley (ver Figura 4), vai notar que na parte baixa do formato do lado do nome do Wrigley está escrito "20.11.1978". Considerando que o programa obedeceu as datas documentadas, poderia concluir que nessa data (segunda-feira, dia 20) o primeiro grupo ainda estava na Cidade do México, cursando a primeira parte do workshop depois do qual pegaram o ônibus com destino a San Miguel de Tzinacapan. Em um cenário menos favorável, naquela segunda-feira (20), o grupo terminou a fase das aulas na Cidade do México, para se embarcar naquela viagem em terça-feira desde cedo. Ao final, o grupo chegou ao convento em Valle de Bravo na tarde daquela mesma terça-feira (21), quase anoitecendo, segundo o programa do workshop (CODIGRAM et al., 1978b).

Se o itinerário não cumpriu-se exatamente, poderia especular que no melhor dos cenários, as aulas técnicas e teóricas foram ministradas da quinta-feira até o sábado, ou seja, de 16 a 18 de novembro na Cidade do México ${ }^{28}$, de forma que o domingo, dia 19, teria sido dedicado à viagem com destino a San Miguel Tzinacapan, de onde o grupo saiu para Valle de Bravo na terça-feira, 21. Aqui, na minha especulação, a mais generosa com o trabalho de campo, o grupo conseguiu estar inserido no povoado -objeto da

\footnotetext{
${ }^{27}$ Aquele lugar era conhecido por Hagerman com relativa antecedência. Na Sierra Norte de Puebla, lugar de San Miguel, Hagerman fez trabalho com comunidades indígenas em companhia da sua mulher Doris Ruíz desde meados dos anos 1970. Hagerman é um arquiteto mexicano, nascido na Espanha e membro do CODIGRAM. Ele é um dos nomes do design mexicano pela qualidade e o sentido do seu trabalho. No relatório escrito por Carl Auböck como representante do ICSID, Hagerman é listado dentro da equipe mexicana do workshop, como encarregado do programa (Auböck, 1979, p. 4).

${ }^{28}$ Na memória de Luiz Blank o curso durou entre três e quatro dias (Blank, 2014).
} 
intervenção tecnológica a ser estudada- por dois dias e meio, supondo que ele realmente aconteceu. ${ }^{29}$

2.

Para alguém que já tivesse experimentado algum tipo de trabalho comunitário, aquela proposta metodológica poderia provocar questionamentos, desde os mais espontâneos -por exemplo se eles teriam tempo suficiente para entender os problemas reais do povoado- passando por inquietações maiores -como, por exemplo, se aquele tempo seria apenas para uma observação romantizada da realidade de povoados camponeses mexicanos e, por consequência, do mundo subdesenvolvido- até críticas ainda mais abstratas -por exemplo, se seria aquele um caso suspeito de intervencionismo-. Independentemente do nível ou da imagem que cada um desenhasse daquele assunto, posso pensar que a proposta metodológica do workshop -na qual estava incluso o trabalho de campo em San Miguel- tenha se tornado motivo de malestar para alguns assistentes.

Vale lembrar que desde décadas anteriores, diversos intelectuais latinoamericanos estavam preocupados com uma certa necessidade por construir a identidade nacional. Com um pouco de paciência pode se rastrear esse interesse em algumas das formas que ele adquire como discurso latino americanista desde o século 19. Tentarei abordá-lo mais à frente. Dai que seja possível afirmar que escolher um "grupo nativo" para o workshop poderia ser tanto uma experiência extraordinária de contato com comunidades indígenas como um insucesso para vários assistentes. Seguramente extraordinário a partir do exotismo que aquela situação encarna, e que tanto criticam os antropólogos na aproximação ao campo. Um insucesso, considerando que "o indígena" e "o camponês" estava compreendido por vários intelectuais latinoamericanos como o local onde se fortalecia a identidade, talvez, não sei, no caminho que afirma Stuart Hall, quando fala da cultura popular... talvez um objeto de elevado respeito e admiração dada a sua latente contestação

\footnotetext{
${ }^{29}$ Coloco a dúvida dado que nenhum dos dois relatórios do workshop mencionam uma visita a San Miguel Tzinacapan. Nem o CODIGRAM, nem o ICSID informam sobre uma viagem para o lugar. 0 relatório de CODIGRAM apresenta uma lista de características gerais do lugar (Martínez \& Gallardo, 1978). No relatório do ICSID não encontrei nada relacionado (Auböck, 1979).
} 
[...] a tradição popular constituía um dos principais locais de resistência às maneiras pelas quais a "reforma" do povo era buscada [pelo capital]. É por isso que a cultura popular tem sido há tanto tempo associada às questões da tradição e das formas tradicionais de vida -e o motivo por que seu "tradicionalismo" tem sido tão freqüentemente mal interpretado como produto de um impulso meramente conservador, retrógrado e anacrónico. Luta e resistência -mas também, naturalmente, apropriação e expropriação (Hall, 2008, p. 232).

\section{Faces da mesma moeda}

1.

Já apresentei os dois primeiros momentos do workshop. Segundo minha interpretação, aulas técnicas, metodológicas e teóricas na Cidade do México no primeiro e -se aconteceu- para uma parte dos assistentes, o trabalho de campo em San Miguel de Tzinacapan. A terceira parte do Interdesign'78 foi o workshop mesmo. Segundo a programação do evento (CODIGRAM et al., 1978b; Martínez \& Gallardo, 1978), desde a tarde da terça-feira, dia 21 de novembro, até a manhã da quinta-feira, 30 de novembro, os participantes estiveram reclusos no monastério em Valle de Bravo.

Ao princípio desse subtítulo mencionei a estrutura daquela agenda de trabalho. Sem contar os dias 21, 26 e 30 -dia de chegada, recesso do domingo e dia de saída de Valle de Bravo respectivamente-, durante sete dias o grupo esteve inserido em uma rotina rigorosa de trabalho em muito semelhante à vida monástica, "estábamos en un convento y nos atendían unas monjas... la comida era estupenda” (Polo, 2014b).

Os assistentes foram divididos em grupos de trabalho, com o propósito de planejar um sistema que resolvesse uma necessidade particular da comunidade indígena em San Miguel de Tzinacapan. 0 grupo Grain Drying With Solar Energy tinha a tarefa de projetar um sistema para secagem de grãos de café que utilizasse energia eólica e/ou solar. 0 grupo Biomass Digester responsável por pensar em um sistema de gestão de resíduos projetou um sistema que poderia ser alterado de acordo com as necessidades locais. 0 grupo Water Pump estudou a possibilidade gerar energia para a transferência de água projetando uma bomba de água com energia eólica. Greenhouse, que assumiu a tarefa de criar estruturas simples que pudessem ser construídas pelo povoado para coletar e usar o calor do sol no aquecimento de água (ICSID, 1978, p. 1). 
O programa estabelecia certas atividades diárias. 0 dia se iniciava com o café da manhã, às 8 horas, e terminava com a sessão de apresentação do trabalho diário por volta das 21 ou 22 horas. Esse programa também determinou uma estrutura temática diária para orientar o trabalho.

\begin{tabular}{ll} 
Hora & Atividade \\
\hline 8h00 - 9h00 & Café da manhã \\
\hline 9h00 - 13h30 & Trabalho da Tercia* \\
\hline $13 \mathrm{~h} 30-15 \mathrm{~h} 30$ & Almoço \\
\hline $15 \mathrm{~h} 30-18 \mathrm{~h} 30$ & Trabalho da Véspera* \\
\hline $18 \mathrm{~h} 30-19 \mathrm{~h} 30$ & Avaliação (depois de Completas $^{*}$ ) \\
\hline $19 \mathrm{~h} 30-21 \mathrm{~h} 00$ & Jantar \\
\hline $21 \mathrm{~h} 00-\ldots$ & Apresentação \\
\hline
\end{tabular}

Tabela 3. Agenda de trabalho do workshop em Valle de Bravo entre 22 e 29 de novembro de 1978. Fontes: Relatório de Interdesign'78 feito por CODIGRAM (Martínez \& Gallardo, 1978) e Working Program, entregado pela organização do evento aos participantes (CODIGRAM et al., 1978b).

* Menções da divisão das horas litúrgicas na vida monástica.

2.

0 primeiro encontro no convento se deu na tarde do dia 21 , das $18 \mathrm{~h} 30$ às $19 \mathrm{~h} 30$. A discussão nesse encontro girou em torno de temas metodológicos relacionados aos objetivos do projeto, aos níveis de avaliação e ao briefing. Considerando a estrutura do programa, é muito possível que essa aula tenha sido aquela intitulada Design Method de Derek Wrigley. 0 mais provável é que nessa primeira sessão em Valle de Bravo foi entregue o briefing de cada grupo: aparentemente um relatório preparado pela organização do evento.

Durante todo o dia 22, os grupos deveriam analisar as condições técnicas, econômicas e de recursos humanos do projeto. No dia 23, cada grupo deveria trabalhar na apresentação e análises das alternativas durante a manhã e na seleção de alternativas durante a tarde. No dia 24 pela manhã, a alternativa selecionada seria estudada segundo as suas condições funcionais, esquemas operacionais e diagramas seriam desenvolvidos durante a tarde. No sábado, dia 25 , os grupos deveriam definir as propostas nos aspecto 
tecnológico, materiais e acabamentos, para então trabalhar na expressão formal, etapa intitulada como "Gestalt" no programa (CODIGRAM et al., 1978b).

0 domingo foi dedicado ao turismo. Na manhã da segunda-feira, dia 27, os grupos definiram os aspectos tecnológicos, de materiais e acabamentos das propostas, preparando os relatórios durante a tarde. Assim, no dia 28 foram detalhadas as dimensões dos projetos e suas especificações enquanto na quarta-feira, 29, de manhã, os grupos deveriam coordenar os resultados para preparar o relatório final e a exibição dos projetos. Na quinta-feira, 30, após o café da manhã o grupo voltou para Cidade do México, onde foram realizados o almoço e a cerimônia de encerramento do workshop a partir das $17 \mathrm{~h} 30$.

A cerimônia de encerramento do workshop é considerada como a quarta e última parte. Segundo a programação, aconteceu na tarde do dia 30 (quinta-feira) na Cidade do México, depois de um almoço oferecido por Carlos Ojeda.

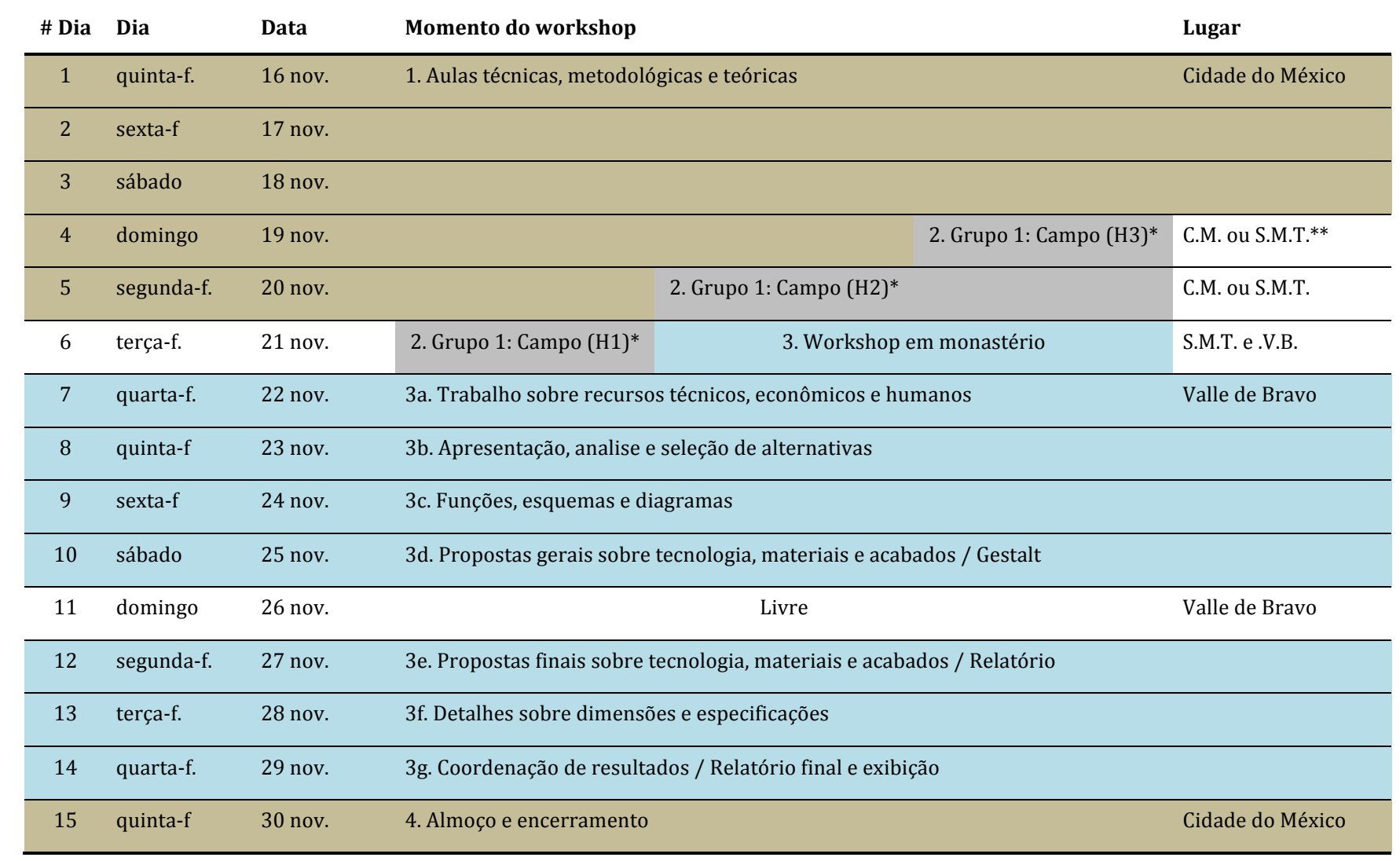

Tabela 4. Estrutura geral do Interdesign 78.

* Correspondem às hipóteses que posso estabelecer com a informação disponível.

** C.M: Cidade do México; S.M.T: San Miguel de Tzinacapán; V.B: Valle de Bravo 
3.

Acredito que o modelo de briefing foi proposto pela equipe de assistência do ICSID aos organizadores locais como o modelo metodológico para o workshop, revelando assim uma face de uma moeda. Penso assim pela importância atribuída ao briefing na estrutura utilizada no Interdesign realizado na Irlanda em 1972 (Gorman, et al., 1977) assim como no realizado no Canadá em 1974 (Fulton, 1975). Nos relatórios desses eventos, a descrição do resultado de cada grupo começa com a apresentação do seu respectivo briefing. Não consegui obter os outros relatórios -é possível que não existirem-, mas imagino que tenha acontecido da mesma maneira nos outros Interdesigns.

No entanto, a relativa coerência que se percebe entre os textos de teoria, metodologia do design e as aulas técnicas propostos pela organização na Cidade do México acaba sendo contraditória quando comparada com os conceitos de briefing e a sua aparição no evento, marcando para mim a outra face da moeda.

Isso sugere uma situação incômoda crescente, especialmente para aqueles participantes que já tinham experiência no trabalho com comunidades. Só para falar do proposto pelo workshop, por exemplo, o texto de Sánchez representava uma linha concreta de pensamento e trabalho em torno da tecnologia e destacava várias condições para o sucesso da solução. Uma delas era a participação das comunidades na determinação e na resolução do problema, como anotei em paginas anteriores. Ao não proceder dessa maneira, arriscava-se condicionar a comunidade à dependência tecnológica, tão graficamente destacada por ele no caso daquela comunidade mexicana em relação com aqueles franceses "the deception of this project has proved to be very profitable for the French and costly to the Mexicans" (Sánchez, 1978, p. 7).

O programa proposto, a quantidade de tempo assim como a qualidade desse tempo dedicado à aproximação com a comunidade de San Miguel de Tzinacapan -nula na prática- evidenciam que a real participação da comunidade não aconteceu. Segundo a minhas contas mais generosas (H3 na Tabela 4), o grupo de participantes do Interdesign esteve em San Miguel dois dias e meio: é claro que não sucedeu assim. Aquela 
aproximação ao lugar foi feita previamente, dentro de um enfoque exótico da comunidade. ${ }^{30}$

$\mathrm{Na}$ situação, as perguntas mais ou menos desconfiadas são apenas esperadas: ${ }^{31}$ quem escreveu aqueles briefings? E como se chegou em tais conclusões? Será que eu, como assistente do workshop e experiente em trabalhos desse tipo, não teria conseguido perceber outro matiz do mesmo assunto ou mais outras coisas, talvez mais importantes? Será que na comunidade de San Miguel vão compreender aquilo que nós projetamos? Essa estrutura logística é a melhor? Será que essa é a maneira mais eficiente de conseguir a qualidade de vida daquela povoação? O que há por detrás desse processo? Para isso são usadas as verbas dos organismos internacionais? 0 que fica para aqueles indígenas após o projeto?

[...] Esto terminó descubriendo algo sobre lo que le he insistido: el diseño ha sido un pretexto de las organizaciones del ICSID para captar los presupuestos de las organizaciones internacionales y de los gobiernos, pero de eso no queda finalmente nada aquí. Eso desde ahí, desde ese taller lo comenzamos a ver. Pero también en los enfoques de diseño. Ahí está el caso de San Miguel, que era el caso que estábamos trabajando en ese taller. Nos impusieron una manera de trabajar para unas comunidades que nadie conocía (Polo, 2014a).

\section{Duas trajetórias... pegadas estendidas}

1.

Neste momento, me parece pertinente apresentar algumas caraterísticas do perfil profissional e pessoal de Luiz Blank e Rómulo Polo, latino-americanos assistentes em Interdesign'78 que terminaram envolvidos no processo da ALADI. Tenho a ideia de que algumas características deles expõem com relativa claridade a forma e a cor que a associação vai adquirir desde seu início. Afinal, se Max Weber tem razão, a ação racional proveem dos fins e valores que governam os imaginários dos homens. E os imaginários, por sua vez, estão sendo alimentados pelas ilusões de chamado, explicando assim o sentido da vocação, esta última dentro da analogia que Weber desenha, para afirmar que

\footnotetext{
${ }^{30}$ Hal Foster escreve: "O primitivo é um problema moderno, uma crise na identidade cultural”, daí a construção modernista do primitivismo, o reconhecimento fetichista e a rejeição da diferença do primitivo" (Hall, 2008, p. 320).

31 Poucos não são desconfiados durante a Guerra Fria. Em meio aos cenários de repressão, estabelecidos durante o período da Guerra Fria na América Latina, a maior parte dos intelectuais e profissionais eram, no mínimo, cautelosos.
} 
a profissão moderna está relacionada com a ideia do chamado secular na vida contemporânea (Weber, 2006). Sem parecer pretencioso e com as proporções devidas, essa ilusão de chamado tem história ao ser gerada em uma estrutura social particular, como uma das melhores garantias de conseguir a explicação social de um assunto social, fazendo apologia de Emile Durkheim (2001). ${ }^{32}$

Apesar da distância geográfica, mas nascidos na mesma década, Blank (1942) e Polo (1945) partilhavam vários assuntos nas suas maneiras de olhar, compreender e criticar a realidade. Eles compartilham no seu próprio caminho um apreço particular pela Arquitetura Moderna onde seguramente os ideais da criatividade social começaram a se aclarar no seu olhar. ${ }^{33}$ Ambos estudaram Arquitetura -Blank não terminou por entrar na Escola Superior de Desenho Industrial (ESDI)-, participando em trabalhos comunitários de arquitetura durante a década dos anos 1960. Polo, trabalhando no Movimiento Universitario de Promoción Comunal (MUNIPROC), um grupo orientado pelo bispo Camilo Torres da Universidad Nacional em Bogotá, que tinha o propósito de intervir nas comunidades da periferia da cidade por meio do planejamento e da construção de postos de saúde, escolas etc. (Polo, 2014a). Blank trabalhou em um escritório de arquitetos, do qual terminaria sendo sócio, enquanto cursava a ESDI. Nesse escritório a maior parte dos projetos era orientado para a intervenção arquitetônica em favelas do Rio de Janeiro. Logo, Blank desenvolveu interesse pelo estudo ergonomia. É bem possível que seu apreço pela Arquitetura Moderna e pelo Design, com a premissa da melhora da qualidade de vida das pessoas, o tenha levado gradualmente por esse caminho. Entre outras coisas, sua experiência comunitária certamente o sensibilizou para tais postulados

[...] Mas eu cheguei na ergonomia trabalhando sobre projeto [no escritório de arquitetura nos anos sessentas], eu sempre ficava pensando quem foi o maluco que resolveu projetar um submarino, né?. E aí um dia eu comprei um livro que era sobre projetos de submarinos e descobri que aquele objeto acarretou o desenvolvimento de uma nova ciência chamada ergonomia [...] aí eu comecei a me interessar por isso.

\footnotetext{
32 Insisto na ideia de não parecer pretencioso. Contudo, acho que o próprio Marx coloca muito melhor do que eu possa sequer articulá-lo "Los hombres hacen su propia historia, pero no la hacen arbitrariamente, en las condiciones elegidas por ellos, sino en condiciones directamente dadas y heredadas del pasado" (Marx, 2003, p. 10).

${ }^{33}$ Sobre a criatividade social falarei em outro capítulo. Posso antecipar que a ideia está relacionada com os paradigmas em que se constrói a arquitetura moderna desde o século 19 para se afastar do campo da arte neoclássica. Uma ideia onde o trabalho criador deve estar orientado à satisfação das necessidades dos outros e não restrita a uma experiência estética no autor.
} 
Aí na ESDI eu disse: esses caras estudam ergonomia. Interessante. Mas na ESDI, eu nunca tive assim, nenhum grande professor de ergonomia, não. 0 primeiro cara com conhecimento mesmo que foi dar aula na ESDI foi o Itiro [Iida], mas eu já tinha saído (Blank, 2014). ${ }^{34}$

Desses postulados, a segura proximidade com as ideias de que cada pessoa está em condições que devem se compreender no seu próprio contexto para ser intervinda, dado que as variações podem ser notórias: desde as qualidades corporais, como as antropométricas e biomecânicas, até as relacionadas com os mecanismos de percepção. Ideias que sensibilizam necessidade de compreensão das necessidades do outro no contexto.

2.

De sua parte, Polo já tinha acumulado uma linha de experiências com trabalho comunitário desde pelo menos o ano 1968, quando começou a trabalhar na Artesanias de Colombia, logo depois no Ministerio de Hacienda entre 1969 e 1976, e na Planeación Nacional entre 1976 e 1978.

Ainda que essas três posições sejam diferenciadas em seus objetivos finais, para todas elas era necessário saber se aproximar das comunidades para que o trabalho fosse eficiente. Na Artesanias de Colombia, em um momento determinado, Polo acompanhou os processos de design que iniciavam em Bogotá e terminavam na produção de uma peça na oficina de algum artesão na sua respectiva zona geográfica; de modo geral, camponeses afastados dos centros urbanos. No Ministerio, era preciso conhecer os detalhes da necessidade e o uso para poder determinar os limites de cada projeto, assim como na Planeación Nacional. No caso do Ministerio, os seus "usuários" eram desde os próprios funcionários que habitavam na província até o contribuinte, que, além disso, devia ser educado na instrução de pagamento de impostos. Na Artesanias e na Planeación, os "usuários" eram, em sua maioria, camponeses ou habitantes de povoados não urbanos.

\footnotetext{
${ }^{34}$ Itirio Iida é doutor em engenharia pela EPUSP (1971). Especializado sobre pequena e média empresa (Osaka, Japão) e planejamento estratégico situacional (IPEA). Coordenador do Programa de Desenho Industrial do MIC/STI (1975-77). Superintendente de Planejamento do CNPq (1980 e 1992-93). Extraído do site (T\&Cdesign). Lida é uma das pessoas mais influentes e decisivas no processo de profissionalização do Design Industrial no Brasil.
} 
Em qualquer uma dessas situações era necessário se informar para poder planejar. Na Planeación Nacional, ele chegou ao posto de diretor do escritório dirigindo equipes de mais de sessenta pessoas compostas de profissionais de diversas formações para que todas as necessidades de projeto fossem resolvidas. Em outras palavras, havia uma equipe de trabalho que determinava em campo as necessidades do projeto. A partir da definição das necessidades, eles pensavam no projeto de design que devia ser projetado

[...] el gran conflicto que encontré en Artesanias, fue darme cuenta de que debía investigar para poder diseñar, mientras que el pragmatismo del gerente de la época [1969] y la visión misma de la estrutura estaba orientada a que hay que producir, producir, producir. Un día le digo yo: "pero es que hay que conocer, conocer, conocer", o sea, no en estas palabras, pero esto significa investigar... él me dijo: "pero que clase de diseñador es Usted que no quiere diseñar"... Le dije: "yo si quiero diseñar, pero no quiero violentar unas cosas que tienen un valor que apenas estamos entendiendo"... porque nadie sabía de artesanías aqui [na Colômbia]... nadie conocía los artesanos (Polo, 2014b).

3.

Polo e Blank, assim como a maioria dos designers envolvidos no processo da ALADI, tinham uma profunda sensibilidade com o papel do design no cenário, por estarem envolvidos tanto na criações de cursos, quanto nos debates sobre as delimitações do campo profissional

[em 1968] a gente começou a contestar o currículo, e a discutir as suas modificações. O currículo era alemão! Nós dissemos qual que é a problemática brasileira? 0 que é que o Brasil quer de um designer? 0 que é que esse tal de design deve fazer e como ele se encaixa na sociedade brasileira? Como é que ele se posiciona frente à sociedade industrial? As preocupações da gente eram essas (Blank, 2014).

[...] Em 68, a gente parou a faculdade, tanto os alunos, professores, fizemos uma avaliação crítica. Fizemos uma exposição no Museu de Arte Moderna que culminou também numa discussão da reforma do currículo da própria faculdade (Abramovitz, 2013).

Essas preocupações também tem relação com o fato de Blank trabalhar como professor, assim como na sua participação nas discussões acerca do currículo mínimo que, naquela época, estavam se iniciando no Brasil e das quais participou ativamente.

Com Polo, o assunto é bem parecido. Ele começa as suas experiências docentes em finais dos anos 1960, as quais vão seguir quase ininterruptamente até os anos 1980. Sempre crítico do ensino que recebeu, teve a oportunidade de planejar e escrever a proposta de curso de Diseño Industrial para a Universidad Javeriana de Bogotá, do qual 
foi coordenador. 0 curso iniciou em 1977, sendo o segundo em Bogotá e o terceiro no país.

Essas e muitas outras coisas fazem parte da definição de uma maneira particular de olhar a realidade: insisto na ideia de que elas deixam perceber as preocupações deles nos ideais da criatividade em função da qualidade de vida, principalmente daqueles em situações menos favoráveis. Mas também deixam perceber que muitas dessas preocupações estavam ativas nas suas próprias realidades. Afinal, os dois, guardadas as devidas proporções, trabalharam para a institucionalização do design em seus países, o que explica inclusive o por quê de sua participação no workshop do Interdesign'78 com esse tema nesse momento. No fundo, quero dizer que estou mais ou menos convencido de que Blank e Polo -assim como Adam, Udagawa, Chiquillo, Rabbat, Robles, Rivera, López, Ortíz e outros no momento do workshop-, tinham discutido o papel do design no contexto de seus próprios países e tinham acumulado vários anos de experiência que os referendava como especialistas. Eles já tinham um entendimento claro do que era o design no contexto quando iniciaram sua participação no Interdesign $78 .^{35}$

\section{Uma joia no caminho!}

1.

Na coletânea de documentos cedida gentilmente a mim por Luiz Blank, está incluída a cópia de um texto que lhe foi entregue durante o workshop. Não consegui determinar se era parte do material do evento ou se lhe foi entregue pessoalmente pelo autor. Esse documento parece ter sido escrito por Pablo Robles em 1978 como texto de apoio para o debate a ser realizado em 1979 dentro da ANIEDI, e como preparação da palestra que essa associação apresentaria no seguinte Congresso do ICSID, que aconteceria em 1979 também no México. ${ }^{36}$ Talvez, dada sua novidade e, talvez, a necessidade de discuti-lo antes da realização do congresso, Pablo Robles ou bem pediu à organização para incluir o documento no material do workshop, ou, ainda mais provável

\footnotetext{
35 Menciono aqueles latino-americanos porque são eles signatários do documento que da inicio ao processo de configuração da ALADI.

36 Pablo Robles é um arquiteto mexicano, assistente ao Interdesign 78 por CODIGRAM. Nesse momento, ele era coordenador da Facultad de Diseño da Universidad de Guadalajara no México, da qual, aparentemente, tinha sido seu criador em 1976. De sua parte, ANIEDI é a sigla da Asociación Nacional de Instituciones de Enseñanza del Diseño Industrial, criada no México em 1977, e que reunia os diretores de cursos de design do país (Rodríguez, 1987).
} 
dado o conteúdo, aproveitou e entregou cópias aos seus colegas, principalmente aos latino-americanos

[...] talvez esse documento é a proposta que deu origem à orientação ideológica da ALADI [...] Daí começou uma discussão... com esse papel na mão, começou um papo, que legal! [...] Mas a partir dessa conversa da formação é que se chegou à questão da informação em si, da disseminação da informação que leva à ideia da ALADI [...] Tinha dentro do ICSID na época, uma discussão de currículo. Essa conversa jogada dentro do Interdesign, levou a gente a pensar... que legal, podia ser um currículo latino americano (Blank, 2014).

Nesse documento, Robles expõe brevemente dois pontos concretos. 0 primeiro, uma rapidíssima reflexão sobre o papel do designer industrial na sociedade. 0 segundo, uma estrutura de conhecimentos, atividades e atitudes necessários ao designer para consegui-lo. Ele defendia a ideia de formar designers industriais com um amplo conhecimento da natureza e da relação do ser humano com ela. Entre vários elementos, para Robles era indispensável que o designer tivesse conhecimentos tanto de ergonomia e antropometria, assim como da sociedade, a partir do que chamou "materialismo histórico" e princípios de "economia política". Um claro interesse técnico e uma ênfase sobre o conhecimento da sociedade a partir de fixações de tom marxista. ${ }^{37}$

Para Robles, esses conhecimentos deveriam ser adquiridos por um designer industrial mexicano, com o objetivo de indicar e resolver necessidades de acordo com a realidade de um contexto determinado

[...] debe ser un crítico de la realidad social y de su própia práctica; pero debe ser un individuo actuante que plantee soluciones [...] a corto plazo debe pensarse en optimizar situaciones reales, en corregir deficiencias, pero de problemas planteados por los que sufren, a fin de evitar el voluntarismo o el romanticismo que impregnan las acciones precipitadas (Robles, 1978, p. 4 o realce é meu).

E deve-se conquistar tanto o principio de estabelecer a situação e sua solução, quanto o feito de fazê-lo com participação dos afetados, dado que não é aceitável que o designer industrial mexicano caia no que ele chama de assistencialismo e/ou problema descontextualizado. Assistencialismo e descontextualização, inimigos do enfoque disciplinar... significantes de uma postura política. Nesse contexto, qual seria a

\footnotetext{
${ }^{37}$ No documento, Robles também está numerando a história cultural, assim como a semiótica, para complementar o conhecimento das "leis de transformação social". A respeito da formação do México, ele acompanha a "Economía Política" do que chama "Estructuras socio-económicas de México". Na sua aposta, tanto aquelas leis quanto a formação mexicana darão os elementos para conhecer a sociedade (Robles, 1978).
} 
interpretação de Robles da estrutura proposta pelo Interdesign? O que pensaria ele quando teve nas mãos o briefing designado ao seu grupo?

\section{2.}

Graças à reflexão que ele faz sobre o lugar do designer industrial na sociedade, principalmente aquela tecnológica e culturalmente dependente, nenhuma dessas coisas podia ser aceitável. Daí que ele encontre só um caminho que dá sentido à existência de um designer em uma sociedade, que está obrigada a adotar modelos externos e a renunciar à construção do seu próprio entorno... o único caminho para Robles é a mudança social

[...] Desde el punto de vista de una sujeción a la realidad, los diseñadores tienen poca cabida en nuestra sociedad; por el contrario, en una perspectiva de cambio su participación en un proceso cultural que tienda a romper con la dependencia, puede ser decisiva a condición de que su formación sea al mismo tiempo transformadora y esté suficientemente basada en nuestra realidad y en sus posibilidades de transformación (Robles, 1978, p. 1).

A sentença é clara quanto a sua perspectiva ideológica e, portanto política dele e, por consequência, desse grupo de intelectuais. Mesmo que com matizes, tons e talvez proporções diferentes, os textos da grande maioria dos envolvidos no processo de reflexão e institucionalização do Design Industrial em vários países da América Latina nesse momento coincidem com a ideia de homologar design com tecnologia, onde eles encontravam as possibilidades de mudança, no sentido marxista mais lato "Ningún pensador ha igualado jamás con más éxito su propio lema "Hasta ahora los filósofos sólo han interpretado el mundo: la cuestión es cambiarlo" (Tesis sobre Feuerbach)" (Hobsbawm, 2011, p. 349).

Já nesse momento não parece tão descabido mencioná-lo. Para Robles, o assunto de fundo não é simplesmente plantear as situações, ainda bem, toda uma conquista. Para ele era necessário intervi-las, projetá-las, pois aí estava o âmago do sentido social do designer industrial: o de mudar a realidade

[...] la ideologia [...] que vivía aproximadamente un tercio de la raza humana [...] los únicos pensadores individualmente identificables que han alcanzado un estatus comparable [con Marx] son los fundadores de las grandes religiones [...] y con la posible excepción de Mahoma ninguno ha triunfado a una escala comparable con tanta rapidez (Hobsbawm, 2011, p. 349). 
3.

Nos coloquemos no lugar de Robles por um momento. O que pensaria um indivíduo, com aparentemente clareza de ideais sobre sua realidade e sobre o papel do Design Industrial em relação a ela, quando foi enfrentado com a proposta do Interdesign. Por um lado, um bloco de conteúdos claramente necessários à contraluz das crises do petróleo desse anos, o que explicava que o assunto das energias alternativas estivesse na pauta. Como Blank e Polo reconheceram, cada um a sua maneira, essas aulas foram muito interessantes e necessárias à sua atividade como profissionais. Na mesma dimensão, ainda que o texto de Sánchez não esteja nas lembranças deles, a ideia da sua circulação, junto com o catálogo da ITDG -aquele grupo do Schumacher- no material do workshop, me permite pensar no trânsito de um grupo de ideias que já eram parte dos paradigmas de vários dos assistentes latino-americanos no evento, e que seguramente permitiram afinar posturas. ${ }^{38}$

Mas contrapondo aquele primeiro bloco, se deparar com um brief na sessão do trabalho naquele convento em Valle de Bravo, deve ter sido, no mínimo, um assunto chocante. Já os textos de reflexão teórica, no entanto, indicavam uma aposta, compreendida em geral como 'dever ser'. A aparição do brief, deve ter significado uma contradição interna dentro do workshop com aquele material e aqueles discursos tratados nas sessões anteriores. Finalmente, o brief reside na lógica do fazer, mas desconhece o cenário de abordagem, tão importante para o papel do designer no texto de Robles, quanto para a ética profissional de Polo. É importante lembrar que Polo renunciou ao seu trabalho na Artesanías de Colombia em 1969, praticamente pelo mesmo motivo.

Mas além disso esse era o confronto de dois modelos de compreensão do design e da área que para eles o continha: a tecnologia. Duas apostas conceituais e, portanto, políticas do papel da disciplina no contexto. Como vamos projetar sem o conhecimento das condições reais da povoação? Como pensar em uma necessidade concreta deles sem sua participação no processo? Vamos cair no condicionamento na forma de viver de pessoas que não sabemos como são? Uma viagem de dois dias e meio -na minha mais generosa especulação- para nos aproximar a uma povoação desconhecida que nem fala

\footnotetext{
380 escrito de Robles permite ver como ele estava familiarizado com as ideias do conhecimento da realidade em contexto para mudá-la por meio do projeto. Quem dá uma olhada nos textos escritos por Polo naquela década, vai encontrar a mesma claridade e as mesmas apostas.
} 
espanhol? A manifestação do condicionamento do que fala Sánchez e a descontextualização, o assistencialismo e voluntarismo que critica Robles?

Se a essas sugeridas perguntas, que são próprias da reivindicação profissional e que unicamente estariam debatendo as abstrações do design e sua metodologia, somo o agravante de que tal situação se estava experimentando em uma povoação indígena, o incômodo pode ter tocado dimensões ainda mais sensíveis e ter estimulado reivindicações ainda maiores. Lembremos que muitos deles ou estavam, ou tinham feito, ou conheciam quem estava estudando as produções aborígenes e camponesas, como um caminho para detectar elementos da identidade nacional, tanto nos discursos abstratos de certas linhas reivindicatórias mais acadêmicas da antropologia e a arqueologia da época, quanto no trabalho artístico da vários nomes da região e a criação de mobiliário e da produção visual como já mencionei

[...] Lo que tienen los tres en común [os três textos que formaram o conceito do Brasil ${ }^{39}$ ] es la denuncia del prejuicio racial y la integración del índio, del negro y de los descendientes del mestizaje a la "nación", identificada hasta ese entonces principalmente con blancos nativos e inmigrantes (Hobsbawm, 2010, p. 318).

O texto de Sánchez indicava que passar por cima da determinação das condições ecológicas e sociais de determinado contexto era garantia para que as variáveis acondiçoem a realidade. Como falei, nas suas ideias isso é errado, pois não permite conseguir o que ele chamava de "functional efficiency" (Sánchez, 1978, p. 2), garantindo, ao invés disso, a dependência tecnológica por meio da simples importação de soluções genéricas. Estando então apenas a um passo da dependência cultural, dado que a intervenção material implicaria, no mínimo, mudanças nos estilos de vida das pessoas.

4.

Não foi falado por ninguém nas minhas conversas com os envolvidos, assim como também não encontrei nada escrito na documentação. Contudo, me atrevo a especular que o modelo do brief no contexto do workshop tenha gerado um grande mal-estar e começou a desenhar a ideia de uma intromissão desrespeitosa na realidade da América Latina em vários dos assistentes. Além disso, se considerarmos o ICSID como uma organização internacional que representava -naquele momento- principalmente

39 Para Hobsbawm, isso aconteceu nos anos 1930, do século 20 com os textos Casa Grande \& Senzala, de Gilberto Freyre, Raízes do Brasil, de Sérgio Buarque de Hollanda, e Formação do Brasil Contemporâneo, de Caio Prado (317-318). 
interesses dos norte-americanos, europeus e japoneses e o contexto do workshop -em uma zona do globo em que se debatem os diferentes modelos de desenvolvimento-, estaríamos à frente de um evento que facilmente posso ter sido entendido como uma recriação colonialista que não vai ser aceita. 0 pessoal latino-americano se formou durante os anos 1960 sob a utopia, dentro das suas próprias lutas pela democracia e o desenvolvimento equitativo.

E, se esse sentimento de intromissão desrespeitosa era inaceitável, à luz das apostas metodológicas e conceituais do que é e do que pode fazer a tecnologia e assim o Design Industrial no nosso contexto -inquietudes que estavam no ar durante o workshop- era igualmente insustentável -para não dizer insuportável-, a sensação de menosprezo que teriam sentido Luiz Blank, Rómulo Polo, e, seguramente, Pablo Robles, assim como outros tantos por parte dos representantes 'estrangeiros' do ICSID.

Seguro que as diferenças metodológicas e conceituais encontradas pelo pessoal latino-americano em relação ao workshop e daí com o ICSID deram margem a mais variada gama de discussões na estadia em Valle de Bravo. Lembremos que o esquema proposto pela organização enclausurou os participantes em um convento durante nove ou dez dias em jornadas bem parecidas com a vida monacal. Aquela clausura e aquelas discussões que eu quero imaginar como as que cuidadosamente desenha Umberto Eco em $O$ nome da Rosa entre domínicos e franciscanos, naquela abadia medieval. Essas discussões parecem ter intensificado e, provavelmente, polarizado o lugar de uns e outros no debate, radicalizando gradualmente as posturas dos envolvidos.

Desse modo, qualquer aposta sobre um desenvolvimento que não estivesse alinhada com os paradigmas que cada uma das partes já tinha fixa no seu olhar, simplesmente ia ser fator de agressão. Polo via um olhar depreciativo por parte do ICSID quando abordando os tipos de soluções promovidas, enquanto Blank sentiu que nas mais diversas ocasiões os latino-americanos tinham sido tradados de forma humilhante

[...] Era un poco el enfoque de Papanek de hacer cosas sencillas para la gente chiquita. Claro, estaba planteado el tema de la tecnología apropiada, de las energías solares, temas interesantes, pero la visión era esa: ¡hagamos cosas para pobres! Nosotros argumentamos que no, que el enfoque tenía que ser otra cosa, tenía que reconocer los valores de la comunidad (Polo, 2014a).

Isso com os bate-papos, assim como as conversas entre cada vez mais amigos que coincidem em mais e mais coisas, à luz das ideias que propõe Robles no seu texto, 
configuraria uma identidade neles, que não tardará em dar a confiança suficiente para se pensar como uma unidade e lidar com os opostos, que já nesse momento representavam tantos males para eles.

\section{0 manifesto}

1.

Fruto desse confronto, daquelas discussões entre os assistentes ao workshop, dos diversos bate-papos entre latino-americanos em torno das formas como era ensinado, organizado e trabalhado o Design Industrial em cada país e, como lembra Blank, de em um jantar oferecido por Oscar Hagerman na sua casa em Valle de Bravo, ficou clara a intensão de criar um espaço no qual essas conversas pudessem continuar. Um espaço de trocas e refinamento dos olhares sobre a disciplina, suas relações com a tecnologia, o sonho da independência tecnológica e da conquista dos ideais culturais que que dão sentido a uma imagem da América Latina autônoma e unificada.

Compreender que o papel do Design Industrial estava orientado à satisfação das necessidades reais da população -sobretudo dos menos favorecidos, respeitando suas características culturais- alinhava o design com a tecnologia, pelo menos, com aquele olhar que defendia a linha argumental do texto do Sánchez e Schumacher, que já comentei.

Tudo parece indicar que o workshop finalizou com um grupo de latino-americanos sensibilizados com a ideia de procurar o que era próprio da região, no sentido identitário, e trabalhar em função de conseguir encontros frequentes. Tanto que, quando Polo chegou em Bogotá, ele escreveu um pequeno manifesto no qual reuniu as ideias que discutiram durante dias no México e que ao parecer tinha começado a esboçar com Blank. Justamente Blank recebe alguns dias depois uma carta chegando de Bogotá, assinada por Rómulo Polo e datada de 5 de dezembro de 1978, a terça-feira seguinte da finalização do workshop. Com a carta vinha o original desse manifesto. ${ }^{40}$

Nesse documento, Polo propunha uma logística para revisar o texto, estabelecendo um intercâmbio epistolar para remover o que estivesse sendo inadequado por quem

\footnotetext{
40 Aquele documento de três páginas e pouco foi intitulado "Documento de Intención" e vai ser o texto que dá início formal ao processo de criação da ALADI. As suas ideias foram postas na mesa em Bombaim, Bogotá, Cidade do México, Medellín e Bogotá, 2, 7, 11, 19 e 24 meses depois, respectivamente. Cada uma dessas apresentações foi somando elementos e ajustando mais outros até conseguir a redação dos estatutos em novembro de 1980, mas sua estrutura foi mantida.
} 
assim o considerasse, e incluir partes faltantes para, por fim, recolher as assinaturas dos que assim estivessem de acordo. Polo encaminha o original para Blank, no Brasil, assim como cópias foram enviadas para Adriana Adams também no Brasil, Francisco López na Argentina, Maria Elvira Udawaga, no Paraguai, Alberto Chiquillo em San Salvador, Alberto Rabbat no Peru, Fernando Ortiz, Sergio Rivera e Pablo Robles no México. Uma cópia, aparentemente assinada, termina sendo encaminhada para Leang Song Lehn na Áustria na sede da ONUDI (Polo, 1978a). ${ }^{41}$

Como va todo en casa? espero que bien y en tu trajajo tambien. yo he llegado bien, y encantado de todo especialmente de la gente, nuestra gente latina.

Te estoy enviando el documento que empezamos a hacer juntos en Valle de sravo. Ojalá se ajuste a lo que planteamos. Espero que la gente del grupo colabore. Eso depende cie nuestro entu_ siasmo.

Puedes enviarne información sobre algunas cosas?, me interesan:

- Educacion en Diseño Industrial

- Programas de desarrollo de Diseño Industrial (Como el que tu diriges)

Un abrazo grande para ti y tu mujer

Espero noticias.
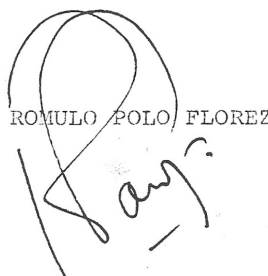

r. polof.

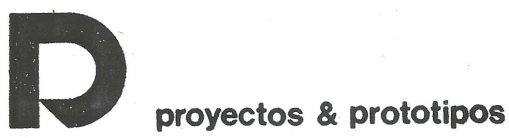

CARRERA 13A NO. 34.43 - TELEFONO (9) 2698041 APARTADO AEREO 13770 - BOGOTA COLOMBIA

Figura 11. Carta remissória do "Documento de Intención".

Enviada por Rómulo Polo para Luiz Blank desde Bogotá cinco dias apos terminado o workshop (Polo, 1978b). Acervo Pessoal Luiz Blank, Rio de Janeiro (APLB).

2.

O propósito parecia ser o de entender as semelhanças conceituais e políticas dos envolvidos, elaborando um primeiro documento que nortearia algumas das ações

${ }^{41}$ Leang Song Lehn era funcionário -talvez diretivo- da divisão de operação industrial na ONUDI. 
necessárias para o estabelecimento formal da associação. Desde o nome da associação, lembrado por Blank como o ato mais corriqueiro, ${ }^{42}$ passando pela determinação do sentido associativo e a natureza dos membros -designers, corpos associativos e instituições nacionais-, referendados nas reuniões seguintes, até o fato de determinar os passos seguintes em prazos concretos. ${ }^{43}$

Por fim, esse documento deixa estabelecido cinco objetivos os quais, alinhando os distintos pontos de debate apresentados nas páginas anteriores, se poderiam reunir em três grandes grupos. Por um lado, o propósito por trabalhar em função do estímulo pelo intercâmbio entre designers latino-americanos, como fazendo eco das inquietudes sobre se encontrarem uma e outra vez e compartilhar experiências, como fizeram em Interdesign 78.

Em segunda instância, estabelecer aquele cenário ao encontro do propósito de afinar os detalhes do que significa e implica a compreensão do Design Industrial como ferramenta para fazer do desenvolvimento tecnológico, econômico e social uma realidade coerente com as necessidades e as carências da região. Por fim, nesse caminho, mas em uma dimensão mais abstrata, questionar, discutir e propor posições frente aos problemas latino-americanos, sobretudo os relacionados com a intervenção estrangeira nas nossas decisões. 0 passo do tempo, da discussão sobre essas ideias escritas, as que se fortaleciam e as que se acrescentavam, explicam os objetivos finalmente propostos em Bogotá em 1980, quando a ALADI foi fundada. Os objetivos que constam na ata de criação, eram desdobramentos dos inicialmente formulados no "Documento de Intención” e que acabaram por definir o caráter da associação desde 1978.

Aí, nasceu o dia e, com ele, a ideia de um organismo regional que permitisse continuar as distintas conversas, tão vivas como ainda hoje se sentem nas suas falas. Ai nasceu a ideia de articular as distintas estrategias a favor de uma América Latina que pudesse configurar sua própria realidade.

\footnotetext{
42 "A ALADI nasce de uma conversa [...] Como é que é o design lá na sua terra? Essas conversas que acontecem quando pessoas que não se conhecem, mas que mexem com a mesma coisa, se encontram... É assim, é? E lá no Brasil é não sei o que e tal. E aí alguém disse, sei lá quem, vem cá, por que é que a gente não discute a possibilidade de fazer alguma entidade que possa manter esse contato que a gente está tendo agora de uma maneira mais ampla e contínua e tal. Aí, que legal!, e como é o nome?. A primeira coisa, né? Como é que a gente chama? Daí deu uma discussão, acabou sendo ALADI, Associação Latino Americana de Desenho Industrial. A coisa maia banal, mas perfeito, né? Foi por isso que pegou" (Blank, 2014).

${ }^{43}$ Troca de informação -pensado de um a três meses-, promoção da criação da ALADI nos respectivos países -seis meses-, fazer o lobby para que uma agência -ONUDI- financiasse a realização de uma reunião latino-americana para criar a associação (Polo, 1978a, pp. 3-4; Polo, et al., 1980b, p. 18).
} 


\section{0 assedio dos intrusos}

[...] Sabemos que nessa amplitude de visão e objetivos, "D(e)iseñ(nh)o Industrial para l(a) T(i)erra Latinoamericana" assume mais um caráter de lema do que de tema. Acreditamos porém que na medida em que consigamos aproximar o segundo do primeiro, estamos trabalhando no sentido de nossas necessidades e aspirações [...] que este encontro represente uma contribuição direta para o fortalecimento da profissão, e indireta para a superação das dificuldades sociais, econômicas, e politicas que afligem nossos países (Redig, 1984, p. 3).

\section{Entrando em Macondoamerica}

1.

Já mencionei que o núcleo das ideias expressadas pelo grupo fundador da ALADI se manteve desde a efervescência dos acontecimentos do Interdesign 78 até o processo de configuração da Associação. No entanto, algumas diferenças aparecem no caminho como esperado- e procuram ser integradas ao núcleo original.

Com expus até aqui, é plausível afirmar que na América Latina existia um processo de sensibilização do design complementado e potencializado com processos para sua institucionalização. Essa sensibilização se inicia com "o precoce" pioneirismo dos intelectuais de vários países latino-americanos desde os anos 1940, e foi fortalecida durante a década de 1960. Assim, quando ocorre o Interdesign 78, há algumas décadas já existia uma crítica coletiva refletindo e empenhada na construção do campo profissional. Não defenderei se era ou não um exercício sistemático, organizado ou estritamente consciente, características que poderiam ser atribuídas a esse mesmo trabalho quando se deu em outras partes do mundo. ${ }^{44}$

Daí que pareça oportuno se perguntar nesse momento pelas motivações existentes nessas reivindicações. Não porque acredite em que vou aclarar ou encontrar o miolo que as configura como ideias, mas pelo exercício de me aproximar das intensões e reservas dos latino-americanos participantes do workshop no México. Como tal, aquelas

\footnotetext{
440 ritmo, o tom e a cor da maioria dos postulados levantados na região nesse período podem dar vida ao enunciado de Alain Touraine e equilibrá-lo quando se observa a perspectiva dos processos históricos do design acontecidos em nossos países sob a metáfora que já marquei: "el actor no vuelve como un ángel sino más bien como un viejo topo" (1987, p. 31).
} 
motivações têm múltiplas frentes e "origens", as quais pretendo rastrear em um capítulo posterior.

Por enquanto, na última parte deste capítulo, gostaria de esmiuçar algumas possíveis razões por trás dessas reivindicações, essas mais próximas da história da institucionalização do design na América Latina do que do estabelecimento de redes e/ou das agendas individuais. Uma série de acontecimentos que pode esclarecer sobre o interesse do ICSID em questões do "Terceiro Mundo", incluindo, claro, a América Latina.

2.

Tudo parece indicar que no interior do ICSID, desde meados dos anos 1960, se começou a ter uma preocupação acerca do subdesenvolvimento, seguramente decorrente das experiências enfrentadas por alguns de seus associados ao trabalhar como missionários em diversos países do chamado "Terceiro Mundo"; pela experiência acumulada por algumas das associações que fundaram o ICSID, especialmente as norteamericanas, e/ou pela sua parceria com o ONUDI. 0 que, entre outras coisas, poderia explicar a realização do workshop Interdesign 78 no México.

No início deste capítulo mencionei como Alessandrini $(2012 ; 2014)$ expõe a relação entre o casal Eames e os irmãos Gautam e Gira Sarabhai, com os consequentes resultados na profissionalização design indiano. Também mencionei as memórias de Pulos (1988) acerca da relação de Peter Müller-Munk com a fundação do Instituto Tecnológico da Índia em Bombaim, assim como outras missões da USAid em parceria com o ICSID em diferentes partes do mundo. Essas missões tinham como objetivo fazer do Design Industrial uma ferramenta para o desenvolvimento naqueles países. Mas também procuravam alinhar amigos na estratégia da propaganda ocidental (quiçá estritamente norte-americana) enquanto tinham acesso a verbas internacionais.

Chien-Tu (2013) o deixa perceber com algum detalhe em Taiwan em 1955 com a participação de nomes como Russel Wrigth e Alfred Girardy, esse último também envolvido na criação da Artesanías de Colombia em Bogotá, em 1964. É sabido que por exemplo Gui Bonsiepe chegou à Argentina como técnico em embalagens, como expressa sua resenha para o The Journal of Tipographyc Research (Bonsiepe, 1968, p. The Authors).

Além da USAid, havia outras agências internacionais envolvidas com programas de desenvolvimento industrial. Margolin (2007) menciona a NORAD (Norweigan Agency for 
Development Cooperation) e o Departamento Britânico para Desenvolvimento Internacional (Britain's Departament for International Development), agências de cooperação que, assim como o USAid, provinham de países que participaram da fundação do ICSID.

Além do caso de Artesanias de Colombia com Girardy, posso colocar o trabalho dos belgas, diretamente envolvidos na criação da ACD (Asociación Colombiana de Diseñadores) e do curso de Design Industrial na Universidade Nacional da Colômbia em Bogotá, entre 1976 e 1978. Essa missão belga ocorreu sob a coordenação de Jorge Cueben, a participação de Dirk Jacobs (ICSID’s board member entre 1977 e 1981) e a supervisão do ICSID. 45

Parece-me óbvio que, na sua própria forma de perceber, vários designers latinoamericanos participantes do evento no México já tivessem notado esse movimento desde os anos 1960 e seguramente, muitos deles o faziam com suspeita. No mínimo, esses missionários estrangeiros eram técnicos especializados que acabam por competir com os profissionais estabelecidos no país aonde chegavam. 0 argentino Francisco López parece sugerir isso em uma carta enviada a Luiz Blank nove meses depois do Interdesign'78

[...] es la única manera de que no se filtren "las personalidades ilustres" [sic] que todos conocemos, o si lo hacen deberán hacerlo a través nuestro. Es a partir de ese contacto oficial entre nuestras Asociaciones que puede salir algo más o menos serio respecto de ALADI. Fragmento de uma comunicação pessoal escrita por López para Blank (1979).

\section{Vamos de safari}

1.

0 interesse desses designers, principalmente os estadunidenses e europeus ocidentais, estava relacionado com uma aparente necessidade do ICSID, de se alinhar com os mesmos paradigmas que já governavam as diretrizes e o discurso de várias agências internacionais da época. Elas em sua maioria eram parceiras da ONU, cujo

\footnotetext{
45 "se hace necesario una mención a las gestiones desarrolladas por la Senora Josine des Cressonnières como principal supervisora del trabajo de la misión belga y como secretaria de la entidad rectora de la profesión en el mundo. Debemos hacer mención también a la amistad que el ICSID a través de la Señora des Cressonnières ha tenido para la Universidad Nacional desde el primer contacto efectuado en el congreso de Buenos Aires en 1969 hasta la vinculación en 1977 de la Universidad como miembro del ICSID” (Sicard, et al., 1977, p. 17). Já voltarei sobre o assunto desse congresso em Buenos Aires.
} 
conceito de desenvolvimento já não era reduzido ao aspecto econômico. Parte dessa problematização é tratada por Messell (2016).

Notemos que, por exemplo, o documento de Vicente Sánchez apresentado páginas atrás afirmava que o conceito de Ecodevelopment foi usado pela primeira vez em junho de 1973, no relatório do Diretor Executivo do PNUMA em sua primeira assembleia (Sánchez, 1978, p. 1).

Me parece que tal conceito, o ecodevelopment, é uma das subsequentes ampliações do conceito de desenvolvimento reduzido ao econômico, que estava pelo menos ultrapassado nos discursos multilaterais desde a metade dos anos 1960. Já mostrei a estrutura geral proposta por Sánchez nesse texto. Para ele o ecodevelpoment estava relacionado com a observância dos fatores econômicos em diálogo com os naturais e os culturais, de tal forma que a presença do ser humano na fórmula era o ponto central do correto projeto de desenvolvimento.

\section{2.}

Nesse cenário, me parece curioso notar a evolução dos temas dos Congressos do ICSID a partir de 1965 em uma direção, digamos, mais "humana". O congresso daquele ano, o quarto na sua história, foi intitulado "Design and the Community"; o seguinte foi realizado no Canadá em 1967, “Man to Man”; e o organizado em 1969 na Inglaterra se chamou "Design Society and the Future".

Em seguida, seria realizado um congresso sem aparente correlação temática. 0 sétimo Congresso, realizado na Espanha, foi nomeado segundo o frio consecutivo, como que com a intenção de não se comprometer. Os japoneses organizam o oitavo, "Soul and Material Things"; e, em 1975, em Moscou, o eixo em torno do ser humano foi retomado, com o tema "Design for Man and Society". "Development Identity" foi o tema do Congresso número 10 na Irlanda em 1977, que seria seguido pelo Congresso na Cidade de México, em 1979. 


\begin{tabular}{llll}
$\#$ & Ano & Cidade & Tema \\
\hline 1 & 1959 & Estocolmo & -- \\
\hline 2 & 1961 & Veneza & Towards an Aesthetic of the Invisible Design of Tradition \\
\hline 3 & 1963 & Paris & Industrial Design - Unifying Factors \\
\hline 4 & 1965 & Viena & Design and the Community \\
\hline 5 & 1967 & Ottawa & Man to Man \\
\hline 6 & 1969 & Londres & Design, Society and the Future \\
\hline 7 & 1971 & Ibiza & Seventh Congress \\
\hline 8 & 1973 & Tóquio & Soul and Material Things \\
\hline 9 & 1975 & Moscou & Design for Man and Society \\
\hline 10 & 1977 & Dublin & Development Identity \\
\hline 11 & 1979 & México D.F & Industrial Design as a Factor \\
\hline
\end{tabular}

Tabela 5. Congressos $1^{\circ}$ a $11^{\circ}$ do ICSID.

Fonte: ICSID / Past Congresses and General Assemblies (ICSID, 1979).

As divisões cromáticas são minhas e se correspondem com as categorias que poderiam se fazer a partir da generalidade dos temas que apresenta a resenha no seu site em internet.

A partir da preocupação do ICSID com o subdesenvolvimento, posso pensar que no coração da Associação Internacional começaram a se construir determinadas visões sobre o papel do designer industrial em países subdesenvolvidos. Isso seguramente explica a realização de um projeto como o Interdesign

The idea to hold an interdesign event was developed at an Icsid board meeting in 1970. It was a response to a common desire amongst designers at the time to break with the narrow concept of productoriented design and become more involved in 'total' projects (ICSIDIDA, pp. 1, o sublinhado é meu).

Aquele afastamento com isso assinalado de "estreito", parece ser fruto de um debate interno entre uma visão profissionalizante da disciplina, herdada e exemplificada pelo exercício dos primeiros membros do ICSID, e uma perspectiva mais abrangente do design que apresentava uma visão até diplomática, como afirmaria Pulos. Debates internos, como este, são esperados quando dentro de uma instituição de tal porte acerca das discussões sobre a jurisdição e a discricionalidade de uma profissão. Mas, também fica claro que as variações nas maneiras como é compreendido o objeto social de uma disciplina está intimamente ligado com o diálogo que ela estabelece com seu contexto, aceitando, traduzindo e/ou rejeitando o que ele -o contexto- lhe sugere ou até lhe exige, 
como propõe Andrew Abbott (1988).

Dado seu histórico instrumentalismo, essa mudança de discurso do ICSID poderia ser explicada pelo interesse em apoiar tecnicamente projetos de alcance internacional para, no caminho, obter recursos para se fortalecer como instituição. Ainda não posso mais que conjecturá-lo; é preciso fazer um trabalho focado nisso.

Aquele debate e sua consequente mudança podem se explicar também pelo que Richard Sennett (2012) chama de "o prazer da comunidade", relacionado com o "espírito de ajudar" e de "ser parte". Para mim, esse último preceito pode ter estado presente nos indivíduos inseridos naqueles debates e nesses processos ao interior do ICSID. Mas, dado o cenário histórico e político da época, assim como algumas práticas anteriores, tenho minhas reservas com os interesses institucionais.

\section{Ajudar os desfavorecidos}

1.

Soma-se aos pontos anteriores, a criação do Grupo 4 dentro do ICSID. Na rápida descrição que Margolin faz sobre as origens do "Design for Development", ele menciona que em 1973, ICSID arrumou uma comissão para tentar compreender o assunto do subdesenvolvimento e a pobreza, e o papel do Design Industrial nessas condições

[...] A year after Papanek's book was published, and perhaps because of it, ICSID formed a working group to discuss ways in which designers could help alleviate problems of the Third World. Known as Working Group 4: Developing Countries (Margolin, 2007, p. 112).

Segundo ele, esse grupo foi composto por Paul Hogan, quem o liderava, Knut Iran, Jorg Glasenapp, Goroslav Kepper, Amrik Kalsi e Víctor Papanek. Deles, só Kalsi era nascido no chamado "Terceiro Mundo". Ele nasceu no Quênia. Suspeito que respirava no âmago a solidariedade e os seus aliados conceituais: o paternalismo, o assistencialismo, o voluntarismo e a ausência de contexto. ${ }^{46}$

Mas por aí não param as curiosidades. Nesse mesmo momento, outra comissão parece ter sido criada no coração do Council. Segundo algumas memórias de Arthur

\footnotetext{
${ }^{46}$ Compreendo por "solidariedade" um olhar vertical, onde quem observa o faz se sentido em vantagem com o observado, tal como expõe Richard Sennett (2012). Precisamente ele contrapõe a ideia de "cooperação" à ideia de "solidariedade", como um mecanismo de aproximação aos outros, na consideração da diferença, mas em condição de igualdade. De fato, dadas as distorções, Sennett inteligentemente ironiza a solidaridade e os seus engendres a partir da reflexão de Michel de Montaigne "quando estou brincando com meu gato, como posso saber que ele não está brincando comigo?” (Sennett, 2012, p. 329).
} 
Pulos (1980 e 1982), em meados dos anos 1960 o ICSID lhe encarregou tomar conta da conceitualização de um currículo direcionado ao ensino de design. Representando a universidade na qual trabalhava (Syracuse University, instituição que aparece muito próxima do programa dos Corpos de Paz desde o governo Kennedy) ${ }^{47}$, Pulos trabalhou nessa comissão juntamente com Tomás Maldonado, que representava a HfG de Ulm e Misha Black, como representante do Royal College of Arts de Londres. Os três países que representavam eram membros fundadores da associação. Os três personagens foram presidentes do ICSID. 48

Tanto esse fato como o consequente interesse do ICSID no tema foram percebidos por vários latino-americanos. Um evento que poderia explicá-lo seria o "Seminário Internacional para o Ensino do Design Industrial nos Países Latino-Americanos", que mencionei no capitulo 1. Ele foi realizado em 1968 com a presença de vários latinoamericanos

[...] Fernando Caracci Onetto, Director de la Ecuela de Artes Aplicadas y del Departamento de Diseño de la Facultad de Bellas Artes, Universidad de Chile; Teresa Gianella, Profesora de la Escuela de Artes Visuales de la Facultad de Arquitectura, Universidad Nacional de Ingeniaría de Lima, Perú; Gillermo Sicard Montejo, Profesor de la Facultad de Artes de la Universidad Nacional de Bogotá, Colombia; Jaime Gutiérrez Lega, Profesor de Diseño Industrial de la Universidad de los Andes, Bogotá, Colombia; Jorge Gilli, Profesor Adjunto de la Cátedra de Cálculo y Proyecto de Máquinas de la Facultad de Ingeniería, Universidad Nacional de Buenos Aires (Rey, 2009, p. 112). ${ }^{49}$

Já nesse nível, parece claro para os latino-americanos que o ICSID estava interessado em pensar um currículo mínimo de design, ou, pelo menos, em debater o assunto. É interessante apresentar aqui uma ideia de Rodolfo Möller acerca do seminário na sua crónica de 1969. Segundo ele, o seminário foi organizado em Buenos Aires por Basílio Uribe $-\mathrm{dez}$ anos depois, ele assinaria, como representante da Argentina, o segundo documento no processo de conformação da ALADI; aquele texto

\footnotetext{
${ }^{47}$ Segundo as lembranças de Polo (2014a), pelo menos William Newman chegou a Bogotá (1965) como especialista em design para ser o diretor de Artesanias de Colombia, aquele escritório do governo colombiano criado por Alfred Girardy entre 1963 e 1964. Newman era formado pela Universidade de Syracuse e, pelo determinado, era membro dos Corpos de Paz.

${ }^{48}$ Misha Black, membro fundador (primeiro vice-presidente executivo), foi o segundo presidente do ICSID entre 1959 e 1961. Tomás Maldonado foi o sexto entre 1967 e 1969. Arthur Pulos foi o duodécimo entre 1979 e 1981 (ICSID, s.f).

${ }^{49}$ Segundo o documento fundacional do curso de Design Industrial da Universidade Nacional da Colômbia, Guillermo Sicard aproveitou a oportunidade para se reunir com Josine des Cressonnières, secretária-geral e board member do ICSID entre 1963 e 1977 (Sicard, et al., 1977).
} 
elaborado na Índia-. Segundo Möller, o próprio ICSID o havia encarregado dessa tarefa de acordo com Rey, por petição de Misha Black-, sendo apoiado pela UNESCO e pelo Instituto Nacional de Tecnología Industrial da Argentina (INTI). Seguramente, não é casual que o seminário tenha sido organizado durante o termo de Tomás Maldonado como presidente do ICSID: não sei. Aliás, como mostrei no capitulo anterior, Uribe trabalhou insistentemente no interior das instituições de promoção do design argentino durante essas duas décadas (1960 e 1970) -a Associação de Designers Industriais da Argentina (ADIA) e o Centro de Investigações de Design Industrial (CIDI)- que seguramente eram membros do ICSID. 50

2.

À criação do Interdesign, à mudança temática dos congressos, à concepção do Grupo 4, e à organização do Seminário Internacional sobre Ensino do Design em Buenos Aires, quero somar outro fato: a celebração do evento na Índia no contexto da criação da ALADI. Esse encontro resultou na assinatura de um acordo entre ONUDI e ICSID, em janeiro de 1979

[...] In April 1977 a Memorandum of Understanding was signed between UNIDO and ICSID to accelerate jointly industrial design activities in developing countries in order to satisfy urgent needs in this field, and to carry out as extensively as possible the promotional activities necessary to alert developing countries to the advantage of including industrial design in their planning process (UNIDO-ICSID, 1979, p. 2).

Tal assinatura pode explicar a presença da UNIDO (ONUDI em português) no workshop no México em 1978 e na reunião na Índia em 1979 como sponsor e explicaria também o movimento dos designers da América Latina para tais eventos. Como apresentei páginas atrás, os latino-americanos presentes no Interdesign 78 que não eram mexicanos, estavam sendo apoiados pela ONUDI.

E assim como explica essa presença, me parece que também explica o espirito de solidariedade que permeava a "ilusão de chamado" dentro do Council e claro, as suas decisões

\footnotetext{
50 Essas não eram as únicas instituições latino-americanas filiadas ao ICSID nesse momento, assim como também não eram as únicas a serem informadas "em primeira mão" sobre o que acontecia no Council. A Associação Brasileira de Desenho Industrial (ABDI) localizada em São Paulo e fundada em 1963, foi aceita como membro do ICSID em setembro de 1965, momento desde o qual assistira a seus congressos (Braga, 2011, p. 93). Mais tarde, o Instituto Técnico Político Nacional de Diseñadores Industriales de Alejandro Lazo também teria ligações estreitas com o Council, assim como aparentemente o governo cubano por meio de Iván Espín.
} 
[...] At time when ICSID aimed at becoming the leading international organization, and design remained a relatively young profession, its promotion of design with a rhetoric of assistance, which implied that design knowledge originated from industrialised nations. Indeed, as ICSID's Secretary General, Josine des Cressonières, expressed at an Executive Board meeting in 1970: "The only justification of ICSID is to help. We must do it with all the assets and means particular from ICSID which derive from its international status and allow for [...] B) a channel of assistance of more advanced countries, no longer in need of help (Sweden for instance) towards those who need (sic) it acutely" (Messell, 2016, pp. 2742, o realce é de Cressonières).

\section{E aí?}

1.

Seja pelo interesse pela experiência dos associados no "Terceiro Mundo" quanto a necessidade do ICSID em se alinhar às expectativas das agências internacionais, ou na circularidade entre uma e outra coisa; a ênfase na discussão interna do ICSID permite perceber que as relações entre o Design Industrial e Subdesenvolvimento eram um dos temas na agenda da Associação a partir da segunda metade dos anos 1960. Esse debate específico complementaria as visões tradicionais do desenvolvimento de produtos industriais, o "narrow concept of product-oriented design", a partir do qual se originou a ideia do projeto Interdesign.

Nessa circularidade, as preocupações de conceituar o design aparentemente deixaram ver duas posturas que se contrapunham. A citação de Papanek, usada por Margolin em seu argumento, pode evidenciá-lo. Falando do dilema no interior do Grupo 4 e os desafios dos debates aí levantados, Papanek (1986) menciona que os assuntos culturais, relacionados com a satisfação das necessidades das populações subdesenvolvidas se opunham ao "high-tech bias of design expansionism felt to be desirable by some in ICSID" (Papanek em Margolin, 2007, p. 112).

Além do tom daquele debate, suas contrapartidas ou até mesmo seus resultados os quais não me interessa tratar aqui-, demostravam a sensibilidade do ICSID com o tema do subdesenvolvimento em defesa de um discurso muito próximo das teses de Schumacher e de Sánchez. Isso levaria à compreensão de que os problemas do design no mundo subdesenvolvido devia procurar pelos baluartes já mencionados na tese de Sánchez para conseguir o sucesso. Lembremos que, para Sánchez, essa sinergia garantiria a quebra da dependência tecnológica da "Periferia" com o "Centro". 
Dessa forma poderia se dizer que o debate do ICSID tem aparente proximidade conceitual com as preocupações dos latino-americanos reunidos no Interdesign 78 que já expus, assim como de tantos outros que se uniram ao projeto da ALADI. Mas também é claro -como tentarei demonstrar em um dos capítulos a seguir-, que a construção latino-americana tem rotundas diferenças e, sobretudo, um caminho de formação bastante distinto daquele que pode ter transitado o ICSID.

2.

Pensando nos locais de realização dos primeiros Interdesign, outra suspeita aparece. Desde 1971 até 1978 foram realizados onze workshops que poderiam ser dispostos em três grupos distintos.

0 primeiro grupo seria composto dos eventos realizados em locais com possibilidade de assistência técnica em algum problema específico relacionado com turismo, infraestrutura ou tráfico urbano. Esses países ou cidades tinham afinidade com “o pensamento ocidental” e efetivamente com o ICSID (Canadá, Bélgica, Áustria e Índia: Ontario 74, Bruxas 75, Serfaus 75 e Bombaim 76-77, respectivamente).

Um outro grupo reuniria regiões nas quais havia constantes debates sobre seus processos de ocidentalização, locais marcados pela luta ideológica sobre sua identidade, se soviética ou não. O primeiro, na minha lista, por sua vez, é o primeiro Interdesign da história, realizado na Bielo-Rússia em 1971. O segundo, em Járkov, na Ucrânia, em 1977. É interessante notar que, nos anos em que o evento aconteceu em cada uma, as duas cidades se debatiam em processos políticos peculiares relacionados ao regime soviético. A primeira assistia a um processo de aparente extinção dos costumes e da identidade "vernácula"; a segunda, à possibilidade do fortalecimento do seu papel na integração tecnológica e política euroasiática. Nos dois casos, processos de afirmação de seu local dentro da União Soviética. Lembremos que nesse "país" -na Ucrânia- nasceu Leonid Brézhnev, que presidiu a URSS desde 1964 até 1982.

O último grupo poderia ser o daqueles locais que pudessem estar sob "ameaça". Países relativamente amigos que, talvez, pudessem mudar de lado ideológico, por causa da expansão de ideais "não ocidentais". A Irlanda realizou três edições do Interdesign: 1972, 1973 e 1976, em uma época de reconhecidos problemas nacionalistas e separatistas entre guerrilhas, como o famoso IRA (Irish Revolutionary Army). Uma edição foi realizada em Hong Kong em 1976 na plenitude da mudança da Revolução Cultural 
Chinesa. Por sua vez, as comunidades rurais do México, principalmente aquelas sob a influência de movimentos guerrilheiros, receberam o Interdesign de 1978.

\begin{tabular}{cllll} 
\# & Ano & Pais & Cidade & Tema \\
\hline 1 & 1971 & USSR & Bielorrússia (Minsk) & The Production and Distribution of Bread \\
\hline 2 & 1972 & Irlanda & Kilkenny & Design for Tourism \\
\hline 3 & 1974 & Irlanda & Kilkenny & Design in the Post Office \\
\hline 4 & 1974 & Canadá & Ontario & Industrial Design and Small Communities \\
\hline 5 & 1975 & Áustria & Serfaus & Safety in Winter Sports, Local Identity at Serfaus \\
\hline 6 & 1975 & Bélgica & Bruxas & Urban Traffic on a Human Scale \\
\hline 7 & 1976 & Irlanda do N. & & The Designer and the Creation of Employment Opportunities \\
\hline 8 & 1976 & Hong Kong & & Traditional Craft skills for Today's Industrial Society \\
\hline 9 & $76 / 77$ & Índia & Bombaim & A New Generation of Urban Hardware \\
\hline 10 & 1977 & Ucrânia & Járkov & Design for the Aged and the Handicapped \\
\hline 11 & 1978 & México & S. M. de Tz/ Mx. DF* & Utilization of Solar and Wind Energy \\
\hline
\end{tabular}

Tabela 6. Workshops Interdesign de 1971 a 1978.

Tomado do documento de apresentação do Interdesign (ICSID-IDA, 2007?, p. 2)

*S.M. de Tz: San Miguel de Tzinacapán; Mx. DF: Cidade do México

As divisões cromáticas são minhas e se correspondem com as categorias que poderiam se fazer a partir da generalidade dos temas que apresenta a resenha no seu site em internet.

3.

É necessário aprofundar nas motivações do ICSID para organizar Interdesigns em locais tão particulares, em momentos tão peculiares. Por enquanto, posso apresentar aqui algumas ideias de H. Alpay, Fatma e Özlem (2003) para delinear uma conjectura. No texto são apresentados alguns aspectos do início da atividade do Design Industrial na Turquia e as relações entre ICSID e USAid quando do estabelecimento de missões técnicas de designers. Essas missões tinham três objetivos concretos: primeiro, promover e comercializar no mercado norte-americano manufaturas locais -sobretudo exóticas- procedentes dos países subdesenvolvidos; segundo, treinar artesões locais para adequar sua produção com o objetivo de atender à lógica do mercado internacional; por fim, ministrar aulas e pequenos cursos de design nas universidades locais, para sensibilizá-las para a criação de programas em design (H. Alpay, et al., 2003, p. 23). 
Esses objetivos parecem ser os mesmos do trabalho de Alfred Girardy na Colômbia (Buitrago, 2012) e em Taiwan (Chien-Tu, 2013), assim como do casal Eames e MüllerMunk, na Índia (Alessandrini, 2012).

E o porquê disso? O que procurava aquela parceria USAid-ICSID?..51 Segundo Alpay, Fatma e Özlem, tudo isso foi disposto no propósito último de alinhar com o Ocidente aqueles países que, em meio à Guerra Fria, debatiam-se sobre a primazia do seu modelo social. Era uma reação -principalmente dos Estados Unidos- à campanha de propaganda cultural que a União Soviética espalhou nos países vizinhos assim que terminou a Segunda Guerra Mundial, e era igualmente um forte reflexo do grande medo dos Estados Unidos ao triunfo da Revolução Cubana. Foi um movimento estratégico para tentar afastar sociedades e seus intelectuais dos ideais comunistas, para dar lugar à necessária "Pax Americana, uma nova era iluminada que seria conhecida como O Século NorteAmericano" (Saunders, 2008, p. 14).

Assim, poderia se ler que as agências multilaterais terminariam privilegiando o direcionamento de recursos para projetos de assistência em locais específicos, detectados sob determinados indicadores durante a fase mais complexa da Guerra Fria. Não é difícil imaginar que era um caminho de ocidentalização -para "estadounizar"vizinhos e amigos. Ao final, o mote de Saunders é eloquente: era A Guerra Fria da Cultura

[...] Gostassem ou não, soubessem ou não, poucos foram os escritores, poetas, pintores, historiadores, cientistas ou críticos [...] cujos nomes não se ligaram de algum modo a essa iniciativa [...] o establisment [sic] da espionagem norte-americana pôs em funcionamento uma frente cultural sofisticada e substancialmente financiada no Ocidente, para [sic] Ocidente, em nome da liberdade de expressão. Definindo a Guerra Fria como uma "batalha pela mente dos homens", ele acumulou um vasto arsenal de armas culturais: revistas, livros, conferencias, seminários, exposições artísticas, concertos e premiações (Saunders, 2008, p. 14).

À luz das proposições de Pulos, talvez não seja estranho pensar que os intelectuais latino-americanos, críticos dos processos de modernização dos seus países e da região,

\footnotetext{
${ }^{51}$ Se esse era o posicionamento da USAid, não é descabido pensar que outras agências apostariam no mesmo caminho. Margolin apresentou as agências norueguesa e inglesa; seguramente a agência italiana seguia a mesma orientação -já mencionei as ligações entre o governo italiano e o Instituto Tecnológico de Costa Rica-, assim como, possivelmente, agências da Alemanha e da Áustria. Em seu depoimento, Luiz Blank disse não saber o porquê do Design Industrial ser um dos programas do Ministério nos anos 1970 mas que em sua opinião, o 06 -nome do programa- estava relacionado ao fato de seu propositor ter ido morar na Áustria (Blank, 2014). Tudo isso precisa ser conferido. São conjecturas que me permito a partir dos indícios que tenho nas mãos.
} 
chegassem a suspeitar sobre tais coincidências. Quão afastada estaria essa estratégia de associações profissionais de cada país-membro, sobretudo dos fundadores do ICSID? Quanto se aproximaram das associações nacionais de designers dos países do "Primeiro Mundo", cujas ligações com a produção material e cultural estava tão claras? Quão afastado desse projeto esteve o ICSID?52 Qual a explicação da proximidade dos projetos do Interdesign com os projetos exercidos e financiados pelos Corpos de Paz do governo norte-americano? ${ }^{53}$

Se o ICSID pensou em se fortalecer com o acesso a tais recursos, as menções de Pulos acerca da estreita ligação da associação com o governo de Washington indicando as ideias da intervenção técnica como subterfúgio para atividades de fundo político não são tão descabidas. Finalmente, é significativo que ele, um dois mais conhecidos expresidentes da associação e quase seu membro fundador, decida chamar de "Altruism and Diplomacy" o capítulo do seu livro no qual aborda o tema.

Claro, todas essas perguntas e ligações são minhas e aparecem quando tento compreender o cenário dos acontecimentos. Porém na sua respectiva forma, nível e tom, não acredito descabido pensar em que os fundadores da ALADI puderam rondar em torno desses esses e outros tantos interrogantes.

\section{A Guerra Fria da Cultura?}

1.

Todas essas conjecturas deixam transparecer os interesses do ICSID nas questões relacionadas ao subdesenvolvimento. Além das motivações para cada um desses debates, com seus respectivos ajustes e/ou mudanças ao interior dele (do ICSID), assim como das formas como cada um deles é materializado, está claro que como tendência

\footnotetext{
52 Tema de outra dissertação, o que tão longe estiveram de escolas tão famosas como HfG-Ulm, se, por uma parte, ela mesma foi financiada com dinheiro do Plano Marshall e tinha evidentes ligações com ICSID. Spitz (2002, p. 346) trata o caso e já falei das menções de Pulos nas que assinala como aquela escola, foi sede dos debates "sobre currículo mínimo mundial" em 1965, junto com Syracuse University em 1967, com apoio da UNESCO (Pulos, 1988, p. 193). Tanto Syracuse como Ulm aparecem constantemente mencionadas como instituições de proveniência de vários desses missionários; ela conseguiu ter a presidência do ICSID com Tomás Maldonado em 1967, e a vice-presidência com Gui Bonsiepe em 1973. Pelos os seus corredores transitaram famosos designers americanos, como, de novo, o casal Eames. Por pouco, Pulos foi professor lá (Pulos A. J., 1980 e 1982).

53 "Vaughn, tal como o já antes mencionado Frank Mankiewicz -que assumiu a direção dos programas da agência na America Latina [Corpos de Paz]-, era ardoroso apologista do desenvolvimento comunitário como instrumento de conscientização política e promoção social dos camponeses e indígenas da região" (Azevedo, 2008, p. 102). Vaughn foi o diretor dos Corpos de Paz para América Latina entre 1961 e 1964 e diretor-geral da agência a partir de 1966.
} 
representa uma sensibilidade desse corpo associativo com o tema e que tais motivações são o caminho que percorreu para concretizá-la.

Mas como também pretendo defender, os latino-americanos inseridos no processo de criação da ALADI, sobretudo no momento em que participavam do workshop do México em 1978 (Interdesign), já tinham percorrido um caminho de amadurecimento de sua visão sobre o papel do design nos nossos contextos, estando essa visão sistematizada ou não. Uma visão da disciplina que se originava a partir de uma mescla de tópicos promovida pela crítica consciente que os latino-americanos faziam de sua própria realidade.

Eram duas realidades que se chocavam. Duas realidades que tinham transitado seu próprio caminho conformando as suas próprias sensibilidades. No mínimo, existia um clamor legítimo por parte dos designers latino-americanos acerca dos acontecimentos do México: há muito eles vinham conceituando, conformando e vivendo o campo profissional nos seus respectivos países (cerca de 15 ou 20 anos em média até 1978). 0 agravante era o cenário no qual o confronto acontecia e, a partir das categorias críticas dos sujeitos, o que ele poderia significar. Afinal, acredito que não era tão grave o desrespeito profissional com o qual o ICSID se relacionou com os designers locais naquele workshop no México. 0 mais complicado era que esse choque estivera fazendo visível outro conduto pela qual o imperialismo se infiltrava na América Latina. Para aqueles que sonhavam com a autonomia econômica e cultural da região, e criticavam sua realidade nas complexidades da Guerra Fria, era um assunto inaceitável. 


\title{
3. Santandercito e Bogotá 1980: o Design Industrial segundo a América Latina
}

\begin{abstract}
[...] if meaning is embeded in the text, the reader's responsabilities are limited to the job of getting it out; but if meaning develops, and if develops in a dynamic relationship with the reader's expectations, projections, conclusions, judgments, and assumptions, these activities (the things the reader does) are not merely instrumental, or mechanical, but essential, and the act of description must both begin and end with them (Fish, 1980, p. 2 e 3).
\end{abstract}

\section{Várias ALADIs no âmago da ALADI}

Entre os dias 6 e 13 de novembro de 1980, foram realizadas a assembleia de fundação da ALADI e seu primeiro congresso. Promovido pela Universidad Javeriana de Bogotá e o PNUD -Programa das Nações Unidas para o Desenvolvimento- e coordenado pelo grupo organizador da Colômbia -Rómulo Polo, Jesús Gámez, Jaime Gutiérrez e Hernán Lozano (Polo et al., 1980c)-, o primeiro congresso reuniu delegados de diferentes países da América Latina com o propósito de expor as experiências e as concepções do Design Industrial em cada país, focando principalmente cada um dos diferentes processos de profissionalização.

0 tom das palestras e a direção para onde aponta o corpus de documentos entregues por cada delegação, assim como os conferencistas convidados pela organização do evento, mostram a linha de debate que, desde o workshop Interdesign no México em 1978, deu origem à ALADI. Adiante, me aproximarei um pouco as linhas que podem ser interpretadas a partir das ideias remanescentes do congresso. Por enquanto, considero importante aprofundar alguns dos detalhes que podem se entrever da assembleia de fundação. ${ }^{1}$

\footnotetext{
${ }^{1} \mathrm{Na}$ assembleia os delegados da Argentina foram Julio Colmenero e Roberto Napoli, do Brasil Valéria London e Joaquim Redig, da Colômbia Jesús Gámez, Luis F. Zapata e Rómulo Polo, da Costa Rica Oscar Pamio, de Cuba Iván Espín e Alfredo Fernandez, do Equador Guido Díaz, da Guatemala Luis Arroyave e Santiago Tizon, do México Cláudio Rodríguez e Sergio Rivera e de Porto Rico Nelly Toledo (ALADI, 1980a). $\mathrm{Na}$ ata figuraram 72 pessoas como membros fundadores da associação (pp. 9-11).
} 

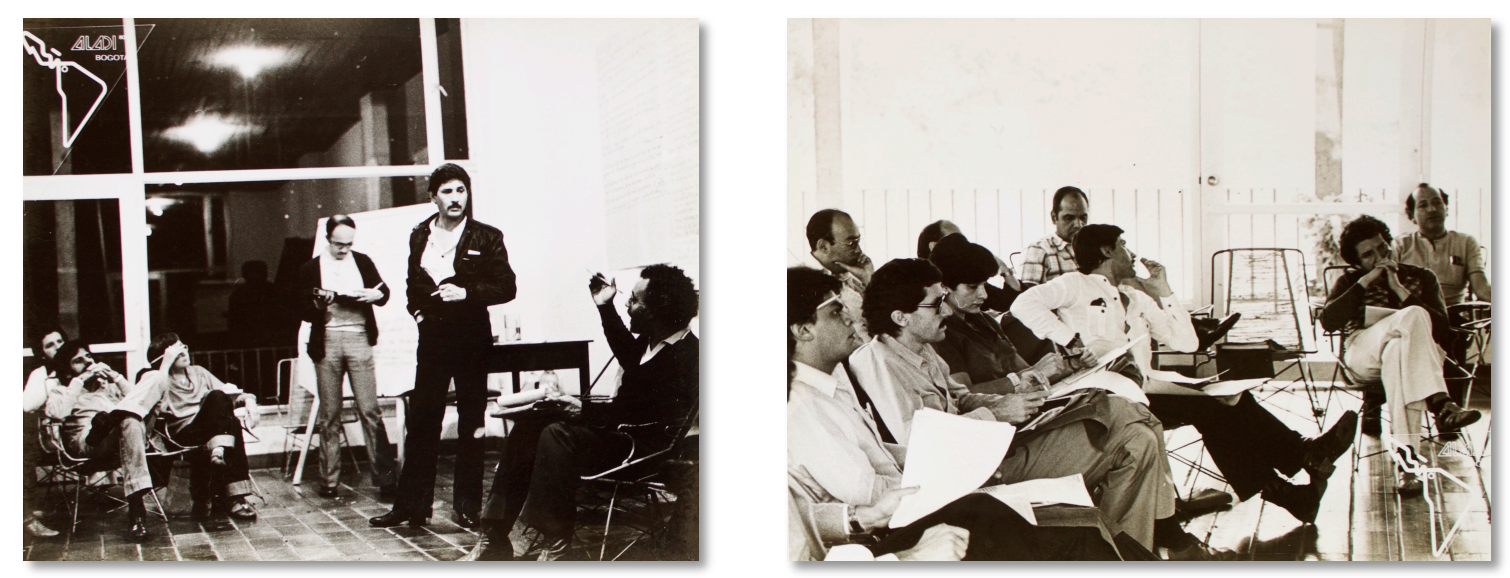

Figura 1. ALADI, Santandercito, Colômbia, Novembro 1980.

A: De esquerda a direita: Joaquim Redig (Bra.), Valéria London (Bra.), Julio Colmenero (Arg.)?, Jesús Gámez (Col.), Roberto Napoli (Arg.)? / B: Sergio Rivera (Mex.), Luis F. Zapata (Col.), Nelly Toledo (P. Rico)?, Jesús Gámez (Col.); atrás à esquerda Julio Colmenero (Arg.)? e atrás à direita: Rómulo Polo (Col.) Acervo pessoal Jesús Gámez em Bogotá (APJG).

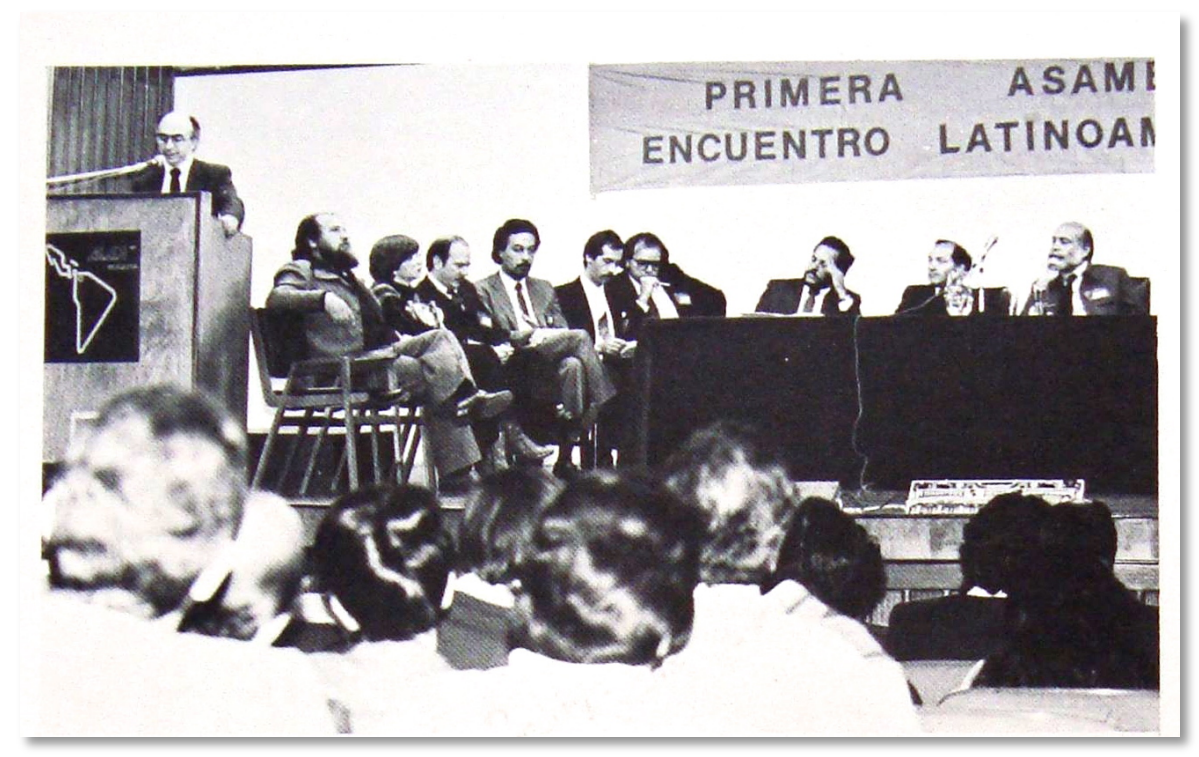

Figura 2. Primeira Assembleia da ALADI. Bogotá, novembro de 1980.

De esquerda a direita: Jorge Valencia (Col.), Guido Díaz (Equ.), Valéria London (Bra.), Julio Colmenero (Arg.)?, Roberto Napoli (Arg.), Claudio Rodríguez (Mex.), Oscar Pamio (C. Rica), Pedro Polo (Col.), Rómulo Polo (Col.) e Iván Espín (Cuba). Fotografia tomada do artigo ALADI, Acta de Constitución, publicado na revista Módulo do Instituto Tecnológico de Costa Rica (1981).

Tudo indica que a assembleia esteve fusionada com o congresso. Por sua vez, algumas sessões de trabalho preparativo foram feitas em Santandercito, um pequeno povoado a $30 \mathrm{~km}$ a oeste de Bogotá, no mesmo Departamento (Estado) de Cundinamarca. Provavelmente, elas ocorreram entre os dias 6 e 8 de novembro. 


\section{Fórum dos fóruns}

1.

A assembleia inaugural determinou uma série de objetivos para a ALADI que foram divididos em quatro grandes grupos: os objetivos políticos, orientados por uma linha de debate contra a intervenção cultural estrangeira; os institucionais, direcionados à constituição de um campo profissional; os de formação profissional, em busca do fortalecimento acadêmico da disciplina por meio da criação de instituições educativas e pesquisa; e, por fim, os objetivos de informação e comunicação, que buscavam a promoção do campo nos diferentes setores sociais.

Além do estabelecimento dos objetivos, essa assembleia também estabeleceu a estrutura, as partes, assim como as responsabilidades e funções da associação. É necessário mencionar aqui que, segundo essas ideias, a ALADI seria a instituição que reuniria os diferentes corpos associativos e as instituições de cada país. Seria representativa dos interesses nacionais em todas as suas frentes -profissionais, educativas, de pesquisa, governamentais e particulares- e um mecanismo de pressão sobre as organizações multilaterais para a operação dos diversos projetos. Ou seja, a ALADI seria o fórum dos fóruns.

Dentro dessas partes também foi definida a assembleia como estrutura, que estaria composta por três delegados de cada país-membro. Tais delegados deveriam responder à estrutura nacional da ALADI por meio dos "Comités Nacionales de ALADI" -CNA-. Dentro das suas obrigações, cabe mencionar que a assembleia era responsável por determinar a política geral da associação; de se reunir ordinariamente a cada dois anos com o objetivo de eleger o Comitê Executivo, que por sua vez seria composto por um Presidente, dois Vice-presidentes, um Secretário e um Tesoureiro. Tanto o Presidente quanto o Secretário e o Tesoureiro seriam escolhidos dentre os delegados do país sede da Assembleia e do Congresso. A escolha do Primeiro Vice-presidente significaria que seu país seria a sede do evento seguinte, dois anos à frente. Enquanto o Segundo Vicepresidente seria o subsequente, quatro anos adiante.

O “Comité Ejecutivo" representava a Assembleia, tinha o compromisso de se reunir pelo menos uma vez no ano e deveria estar em constante contato com "El Comité Consultivo", ao que voltarei em breve. Entre as múltiplas obrigações atribuídas a ele, relacionadas com a gestão de projetos aprovados pela assembleia, a representação internacional, os planos de gastos etc., me parece importante destacar a redação do item 
10 da ata: "Función transitoria: Llevar a cabo los trámites correspondientes para el registro de la ALADI, como organización Internacional” (ALADI, 1980a, p. 8).

Destaco essa função pelo fato de que, ainda que "transitória", ela vem sendo materializada como objetivo desde o "Documento de Intención" redigido no Interdesign 1978, no México. Aquele documento que Polo enviou para oito latino-americanos com cópia para Leang Song Lehn, funcionário da UNIDO na Áustria. ${ }^{2} 0$ propósito de enviar esse documento para a Áustria era envolver o órgãos multilaterais na criação da ALADI por meio do financiamento do evento, como explicado no final desse documento. 0 congresso inaugural da ALADI em Bogotá, em 1980, foi acompanhado pelo PNUD, sendo que Bruno Guandalini, fez uma palestra como seu Representante Adjunto. Alguns anos mais tarde, em 1989, a ONU reconheceu a ALADI como entidade consultiva. Possivelmente uma das maiores conquistas da associação em relação ao seu reconhecimento.

Por sua vez, o chamado "Comité Consultivo" era um terceiro braço da ALADI e estava composto pelos "Comités Nacionales de ALADI", os quais eram unidades representativas da associação em cada país. Seus membros participantes tinham naturezas diversas: desde associações profissionais, passando por instituições de ensino e pesquisa até grupos governamentais. Esses delegações tinham o propósito de representar os designers de cada nação e funcionavam com autonomia, elegendo três representantes para a assembleia, sendo que um deles deveria ser nomeado seu coordenador.

2.

Respeitando a estrutura definida, nessa primeira assembleia foi eleito o $1^{o}$ Comité Ejecutivo, com Rómulo Polo da Colômbia como Presidente entre 1980 e 1982; Iván Espín de Cuba como Primeiro Vice-presidente, significando que Cuba seria a sede seguinte da ALADI (1982-1984); Valéria London do Brasil como Segunda Vice-presidente, assinalando que a subsequente sede seria o seu país (1984-1986); Luis Fernando Zapata da Colômbia como Secretário e Jesús Gámez também da Colômbia como Tesoureiro. Igualmente designou-se um grupo de 72 pessoas como membros fundadores da ALADI.

\footnotetext{
${ }^{2}$ Como mencionei, os oito latino-americanos são Adriana Adam e Luiz Blank no Brasil, Francisco López na Argentina, Maria Elvira Udawaga no Paraguai, Alberto Chiquillo no Salvador, Alberto Rabat no Peru e Fernando Ortiz, Pablo Robles e Sergio Rivera no México.
} 
Membros Fundadores da ALADI

\begin{tabular}{|c|c|c|}
\hline Olicio C. Pelosi & Adriana Canales & Carlos Daniel Soto \\
\hline Franca Rosi & Roberto Napoli & José Luis Berrueta \\
\hline Oscar Pamio & Carlos Chávez Aguilera & Guadalupe González \\
\hline Luis E. Arroyave & Carlos Carillo Soberón & Luis Romero Rwgús \\
\hline Joaquín Redig & Francisco García Noriega & Luis Sierra Campusano \\
\hline Iván Espín & Jesús Virchez & Sergio Sotelo A. \\
\hline Luz Marina Gómez S. & Anne E. Madrid G. & Felix Fernández \\
\hline José Antonio Gallardo F. & Raúl Eguila Nalo & Fernando Shultz \\
\hline M. M de las Heras Polanco & Miguel A. Martínez & Ricardo R. De Tarsio \\
\hline Miguel Marín P. & Fco. Manel Lazo & Nelly Toledo \\
\hline Anamaria de Moraes & Guillermo Sicard & Patricia Guizar Reyes \\
\hline Gui Bonsiepe & Enrique Román Quintanar & Claudio Rodríguez \\
\hline Rodrigo Walker & Walter Oehler de la Mora & Carlos R. Cadena \\
\hline Francisco Masjuan & Carlos M. Caballero L. & Edgar Peregrina Marroquín \\
\hline Ricardo Blanco & Francisco José Soto U. & Luis Soto Walls \\
\hline Francisco J. Santos Z. & Jairo R. Acero & Manuel Ignacio Mier \\
\hline Basílio Uribe & Gabriel Bernal Ruiz & Carlos E. Kohler \\
\hline Dolores Ortíz & Ingo Werk & Luis Fernando Zapata \\
\hline Jesús López Veloz & José M. Rodríguez & José Luis Alegría \\
\hline Cecilia Durán & Sergio Rivera Conde & Rómulo Polo Flórez \\
\hline Jaime González Yapor & Francisco Manuel L. & Enrique Camargo \\
\hline Andrés Hayus du Tilly & Michael Weiis & Julio Colmenero \\
\hline Alfredo Fernández & Jorge Vila Ortíz & Jesús Gámez \\
\hline Santiago Tizón & Valeria London & Guido Díaz \\
\hline
\end{tabular}

Tabela 1. Membros fundadores da ALADI. A ortografia se corresponde com o listado registrado na Ata Fundacional da associação (ALADI, 1980a, pp. 9-11).

\section{Senso comum}

1.

Em relação ao congresso, é importante considerar pelo menos duas dimensões complementares. A primeira é a qualidade geral das exposições apresentadas pelas delegações e os grandes grupos nos quais poderiam ser organizadas. Isso vai mostrar as 
"ALADIs" existentes no interior da ALADI quando da sua fundação. ${ }^{3}$ A segunda dimensão está relacionada com um certo aprofundamento das ideias que atravessam aqueles documentos, mostrando a evidente coincidência nos postulados.

Segundo a documentação recolhida -acervo da Biblioteca da Universidad Nacional de Colombia em Medellín, que agradeço novamente a meu caro amigo Augusto Solórzano- o congresso parece ter sido organizado em dois grandes momentos: o primeiro foi um grupo de convidados externos, que também poderiam ser divididos em duas categorias. A primeira sendo formada por aqueles conectados a esferas institucionais maiores, que ligavam o primeiro congresso da ALADI com a ONU e com as perspectivas desenvolvimentistas do governo colombiano. Nessa categoria estava a palestra apresentada por Bruno Guandalini como representante do PNUD (UNDP em inglês), na qual fez um diagnóstico do processo de desenvolvimento dos países da América Latina e os seus principais problemas. É claramente um discurso multilateral, amplo, que acaba justificando vários objetivos e reivindicações da ALADI

[...] no en todos los casos los problemas del subdesarrollo son un problema de recursos. Por el contrario, los problemas del subdesarrollo mas a menudo son problemas de políticas y de estructuras institucionales. Es decir, lo que hace pobre a un país en muchos casos no es la falta de recursos en sí, sino la pobreza de sus políticas y de sus instituciones para la utilización de sus recursos (Guandalini, 1980, p. 5).

Atrevo-me a dizer que a equipe organizadora da ALADI/Colômbia aproveitou a presença do PNUD como uma oportunidade para desenvolver a linha de argumentos que definiram várias das apostas já estabelecidas, as mesmas que orientaram a fundação da associação. Na verdade, a generalidade do discurso de Guandalini pode justificar praticamente qualquer discurso associativo reivindicatório.

A outra palestra que pode ser incluída nessa categoria institucional foi a ministrada pelo representante de PROEXPO -escritório do governo colombiano que promovia as exportações-. ${ }^{4}$ Nessa apresentação, a partir de um diagnóstico mais ou

\footnotetext{
3 Tanto Valéria London (Brasil) quanto Rómulo Polo (Colômbia) falam da existência desses níveis. Como entendi nas conversas com eles, para Valéria, mais relacionada com os processos históricos do design por grupos de países (London, 2013). Para Rómulo, a partir desses processos, na relação com as complexidades institucionais e sociais de cada caso (Polo, 2014a).

${ }^{4}$ Já mencionei a estreita relação que tem esse escritório com a institucionalização do Design Industrial na Colômbia. Segundo o estabelecido até agora nas escassíssimas pesquisas, se ele não foi a primeira instituição a mencionar o Design Industrial antes da criação de algum curso acadêmico, com certeza foi a segunda (a primeira pode ter sido Artesanias de Colombia, em 1964). Além disso, é PROEXPO quem contratou a "Misión Belga" (1975), na qual está Dirk Jacobs (logo depois board member do ICSID 1977-81). Entre outras coisas, essa missão vai propor a fundação da "Asociación Colombiana de Diseñadores"
} 
menos claro do desenvolvimento econômico do país, Juan Buenaventura expôs o Design Industrial como solução para conquistar o desenvolvimento industrial colombiano, focando na qualidade dos produtos industrializados e em suas embalagens para o triunfo nos mercados internacionais. Argumento do qual ele justifica a profissão no contexto colombiano.

Ainda que superficial quanto ao tratamento dos conceitos e as noções que já circulavam naquela época sobre a profissão, o tom e a cor de algumas das ideias de Buenaventura também contribuíram para o reconhecimento institucional das perspectivas da ALADI, como aconteceu no caso de Guandalini do PNUD.

2.

Vale mencionar aqui uma curiosidade que aprofundarei à frente. Dos 35 documentos que estão relacionados com o primeiro Congresso da ALADI, o texto de Buenaventura é o único que cita ideias de um terceiro: de Gui Bonsiepe. De acordo com as referências feitas por Buenaventura, essas ideias são tiradas de um livro que ele chama de "Diseño Industrial" em algumas menções, e de "Artefacto y Proyecto" em outras. ${ }^{5}$ Acho interessante assinalá-lo por duas razões: uma pelo fato de que esse texto já recolhia uma potente reflexão de Bonsiepe sobre as relações entre Design Industrial, tecnologia e política. Contudo, Buenaventura não só não as menciona, mas usa as ideias referentes à competição nos mercados internacionais por meio da produção de produtos com qualidade como garantia de sucesso

[...] "ya a comienzos de este siglo, el diseñador es interpretado como una herramienta para los intereses económicos de algunas naciones. Portavoces oficiales acentúan la necesidad de mejorar la calidad de los productos, para así estimular las exportaciones, y sobrevivir a la competencia de los mercados extranjeros". La cita anterior de Bonsiepe nos lleva directamente a la conjunción de dos de los factores técnicos que influyen en el éxito de una exportación; la calidad y el diseño [...] Es el mismo Bonsiepe quien en otro aparte de su obra nos dice: "Por calidad no solo se entienden los aspectos visuales de los productos, sino que también abarca otros aspectos, como son durabilidad, mantenimiento, estética, funcionamiento, etc." Y es aquí cuando cobra valor la tesis fundamental de "Promoción de las exportaciones a traves del diseño industrial" (Buenaventura, 1980, p. 6).

(1975), assim como a criação do curso de "Diseño Industrial" na "Universidad Nacional de Colombia", em Bogotá -terceiro da cidade e quarto do país em 1978- (Buitrago, 2012).

${ }^{5} \mathrm{O}$ escrito de Buenaventura não traz a referência bibliográfica completa. Contudo, pegando as duas menções, assim como as ideias daí extraídas, é possível pensar que está citando o livro Diseño Industrial. Artefacto y Proyecto, publicado em Madri, em 1975, por Alberto Corazón Editores. 
É interessante ver como são usadas as ideias de Bonsiepe para fortalecer uma linha de argumentos. A maioria de nós sabemos que nesse texto de Bonsiepe essas citações não representam necessariamente sua tese principal. Claro, é o discurso de um dos poucos especialistas que nesse momento tinham publicado escritos no mercado sobre o tema -design- e a urgência de um funcionário governamental por justificar seu ponto de vista. A partir daí, a necessidade de citá-lo. ${ }^{6}$ Porém, mais adiante, Buenaventura vai citar novamente Bonsiepe; dessa vez, ficando um pouco mais perto da ideia principal dos seus escritos

[...] es el mismo Bonsiepe quien nos dice: "Los productos industriales forman una parte creciente del medio ambiente artificial. Son expresión de una cultura. Diseñar, con enfoque innovativo, implica la creación de una identidad cultural, reduciendo así la dependencia cultural" (Artefacto y Proyecto. Gui Bonsiepe.) (Buenaventura, 1980, p. 6).

Mas imediatamente Buenaventura usa a dimensão mais geral desse postulado para justificar o seu próprio ponto de vista e assim validar o olhar sobre o design industrial com o qual a PROEXPO tinha trabalhado durante a década toda

[...] y es este el momento de preguntarnos. ¿Sería auténtica cultura la nuestra, exportar por un puerto diseños que hemos importado por otro? ¿Colocar a nuestros productos de exportación el sello que dice "Hecho en Colombia" sobre el borrón de anteriores marcas foráneas, por el simple hecho de querer acumular divisas? Tal vez esas divisas podrían llegar a utilizarse en el funeral de una política errada de promoción de exportaciones (Buenaventura, 1980, p. 6).

No primeiro ponto, Buenaventura utilizou algumas das premissas de Bonsiepe que não necessariamente estavam próximas das teses centrais dos textos que ele referencia. No segundo momento, quando Buenaventura se aproxima do coração dessas teses, imediatamente as desvirtua ao instrumentalizá-las para justificar seu argumento e a visão que a PROEXPO defende em relação ao design industrial.

Acima mencionei que duas razões me motivavam para assinalar aquela curiosidade. Acompanhando essa que acabo de apresentar, o fato de que dos 35 documentos só houvesse um com referências a um outro me direciona, por sua vez, a

\footnotetext{
${ }^{6}$ É importante lembrar que PROEXPO foi fundado ao final dos anos 1960 e início dos 1970, com o propósito de promover as exportações colombianas. Um dos objetivos que justificam sua conformação vai ser assessorar em qualidade e design industrial (Buitrago, 2012, p. 50).
} 
pelo menos mais duas questões. ${ }^{7}$ Uma, que as pessoas encarregadas da redação dessas palestras ou artigos não estivessem acostumadas com os formalismos acadêmicos que são hoje vigentes, e que temos herdado das humanidades quando escrevemos. A segunda questão é que a inexistência de citações pode indicar uma legítima apropriação das ideias que transitavam nos círculos dos atores no formato de senso comum, o que faz com que dificilmente se reconheça a fonte de onde são tiradas, considerando assim ideias, premissas e enunciados, como seus próprios. Talvez por isso os postulados similares sejam tão frequentes nesses escritos, apesar da distância geográfica e até mesmo linguística dos seus autores. Analisarei essa questão com mais profundidade em breve.

\section{3.}

Continuando com a estrutura do congresso, essas conferências de Guandalini (PNUD) e Buenaventura (PROEXPO) foram acompanhadas pelas exposições de um grupo de engenheiros colombianos que estavam tendo experiências no tema das tecnologias adequadas e/ou próprias. Eles apresentaram falas nas quais expuseram desde reflexões sobre estudos de caso, até relações conceituais entre tecnologia e cultura, baseadas em ideias do respeito pelo contexto e as práticas dos indivíduos.

Uma delas parece ter tentado estabelecer uma ligação mais clara com o design, considerando o trabalho interdisciplinar como resposta para a solução das carências existentes nas comunidades rurais latino-americanas, inclusive, propondo-lhe mudar ao design- seu direcionamento no projeto de produtos. Nessa palestra, Raúl Gómez defendeu que o designer tinha todas as competências para ajudar a projetar os mecanismos que fariam eficiente o trabalho rural com todos os benefícios que isso significaria

[...] siendo un campo en el que no hay diseñadores, un movimiento del diseño de productos hacia el diseño de dispositivos e implementos que maximicen y optimicen el uso de la mano de obra, permitirá consolidar y superar, dentro del conjunto de la sociedad, esa etapa intermedia del desarrollo en la cual el apoyo a la mano de obra aparece muchas veces como mas apropiado que la producción mecanizada, al considerar el conjunto de los factores de producción existentes [...] La participación

\footnotetext{
${ }^{7}$ Ao mencionar que dos 35 documentos só um usou citações de terceiros, não estou sendo completamente sincero. A verdade, é que mais outro documento fez uma citação, ainda que esteja como parágrafo de início do documento. Foi a palestra apresentada pelo engenheiro colombiano Raúl Gómez Acevedo, chamada "Diseño y Desarrollo Tecnológico". Aí, ele inicia o escrito com um enunciado do argentino Oscar Varsavsky.
} 
activa de la comunidad, particularmente de los productores, cuando del diseño para el nivel no desarrollado se trate, deberá ser una actividad central del proceso de diseño (Gómez, 1980, p. 4 e 6).

Nessa última parte da citação, evidentemente repousam as ideias que a ONU defendia sobre a tecnologia, sintetizadas no documento de Vicente Sánchez que abordei no capítulo anterior. E claramente põe na mesa os debates que deram origem à ideia de criar uma associação latino-americana de design industrial. Todo aquele cenário vivido no México em outubro de 1978 -nesse Interdesign- chegando em Bogotá em 1980.

\section{Heterogeneidade, o design industrial na América Latina}

1.

O Congresso também parece ter tido um bloco de apresentações de palestrantes por país, que acompanha as apresentações por personagens externos à associação. Lembremos que nove delegações de países latino-americanos estiveram presentes na assembleia fundacional da ALADI, porém, parece que nem todas elas fizeram palestras no congresso. No acervo da Universidade Nacional em Medellín, há documentos das apresentações de sete países: Argentina, Brasil, Colômbia, Costa Rica, Cuba, Guatemala e México. Mais adiante tratarei dos discursos dessas palestras, assim como da documentação que cada delegação entregou como memória para o congresso. Por enquanto, quero mencionar algumas generalidades que são características notórias desses documentos como acervo.

Dado o conteúdo desses documentos, é evidente que a equipe organizadora da Colômbia estabeleceu a institucionalização do design em cada país como tema do Congresso, como tentando fazer um estado da arte do processo na região. Esses documentos mostram as diretrizes que norteavam o exercício de profissionalização em cada país: desde os desafios e problemas do mercado profissional, passando pelas complexidades dos seus corpos associativos, seus problemas e as relações com a sociedade, até o sentido das formulações dos cursos de design que se multiplicaram sistematicamente durante os anos 1970.

Também posso mencionar a existência de sistemáticos exercícios de reivindicação dos ofícios artesanais e as tradições indígenas nesses documentos, na grande maioria dos casos qualificando os povos indígenas pré-colombianos como os verdadeiros habitantes da América Latina e a principal fonte de reconhecimento da nossa identidade 
e da diferença com o europeu e norte-americano. No capítulo seguinte mostrarei como essa ideia vem cruzando o ideário de uma linha de intelectuais latino-americanos desde o século 19. Esse exercício estava mais aparente nos discursos mexicanos, costariquenhos, guatemaltecos, colombianos e ainda em algumas ideias de alguns documentos brasileiros entregues pelas delegações. A reivindicação cubana vai ter um tom claro e diferenciado de luta pela autonomia, enquanto os argentinos parecem mais preocupados pela reivindicação profissional em sentido estrito. ${ }^{8}$

Da mesma forma, pela documentação entregue, fica evidente que o Brasil estava vivendo um momento agitado em torno da reivindicação profissional -aquele congresso em Bogotá é contemporâneo com a fundação das APDINS-RJ/PE-. Com a documentação nas mãos, posso dizer que as agendas dos outros países não estavam tão agitadas como a brasileira, mas abordavam as mesmas questões.

A delegação brasileira parece ser a mais complexa em termos de estrutura de representação e trabalho institucional. A cubana, de certa maneira, era a mais respaldada por ser uma representação governamental. A delegação do México apresentava uma heterogeneidade associativa que parece ter respondido a diferentes interesses dentro do país. De fato, parece ser o único país que apresentou duas palestras no congresso de Bogotá.

É claro que alguns elementos emergem como elementos similares. Em todo caso, quando se fala da América Latina como unidade, é importante ressaltar que existem processos diferentes em cada país -e até região dentro de cada país- no relacionado com a institucionalização do design. Os caminhos percorridos por cada sociedade dá caráter a cada processo, outorgando-lhes distintos matizes e particularidades. Considerar a existência de várias ALADIs no âmago da ALADI demonstra não só o princípio de respeito às diferenças, como também o de permitir que cada delegação defina seus próprios caminhos com relativa autonomia.

2.

A fundação da ALADI pode, então, ser compreendida como o momento e o lugar em que esses diferentes corpos associativos se encontraram. Corpos associativos de

\footnotetext{
${ }^{8}$ Com isso não digo que as outras delegações não se mostrem interessadas no debate da jurisdição disciplinar. Em breve mostrarei a reiterada menção e o sistemático trabalho de conceitualização de todos os países nesse sentido.
} 
cada país latino-americano que na sua grande maioria reuniam os criadores e encarregados de implementar as primeiras instituições relacionadas ao design em seus países, tanto dos primeiros programas acadêmicos de design, como associações profissionais. Dai pensar que tanto esses debates, como as decisões e posturas que estavam sendo trabalhadas em Bogotá pelas delegações, estavam configurando o que América Latina pensava sobre o papel social do design... estavam traçando a sua geografia nesse enorme território. ${ }^{9}$

$\mathrm{Na}$ documentação correspondente ao primeiro congresso da ALADI em Bogotá é possível encontrar cinco ou seis grandes tipos de enunciados que permeiam as ideias com relativas coincidências. São proposições relacionadas com categorias críticas que debatem as características do modelo econômico e social da região para problematizar o design e não tanto, o que para esse momento em outros lugares tinha se formulado como o papel da disciplina. Como adiantei e pretendo aprofundar aqui, tanto a ausência de referências a outros autores, quanto a evidente -ainda inconsciente- tributação deles para categorias gerais da CEPAL, a crítica comunista, a Teologia da Libertação e a reivindicação latino-americanista o evidenciam. É importante afirmar desde já que considero essa ausência de referências como sintoma de um nível de apropriação de ideias, que já parecem instaladas nos imaginários de intelectuais da região... algo que poderia se explicar desde determinada parte das abordagens do "inconsciente coletivo" de Jung

[...] é uma parte da psique que pode distinguir-se de um inconsciente pessoal pelo fato de que não deve sua existência à experiência pessoal, não sendo, portanto, uma aquisição pessoal [...] [seus conteúdos] nunca estiveram na consciência e, portanto, não foram adquiridos individualmente, mas devem sua existência apenas à hereditariedade [...] consiste de formas preexistentes, arquétipos que só secundariamente podem tornar-se conscientes, conferindo uma forma definida aos conteúdos da consciência (Jung, 2014, p. 51 e 52).10

Nas páginas seguintes, tratarei as séries que mais quantidade de enunciados apresentam esses documentos reunidos em três grandes blocos.

\footnotetext{
${ }^{9}$ A coletânea que repousa no acervo da Biblioteca da Universidad Nacional na cidade de Medellín está composta por 35 documentos: 3 argentinos, 16 brasileiros, 8 colombianos, 1 costarriquenho, 2 cubanos, 1 guatemalteco e 4 mexicanos.

10 Me parece ilustrativa a explicação de Jung sobre essa questão, principalmente no que diz respeito da diferencia entre os dois tipos de inconsciente: pessoal e coletivo. Contudo a forma de compreender a relação entre o ultimo e a sua ideia de arquétipo, claramente é impertinente no meu interesse, para dizer o mínimo.
} 


\section{Jurisdição e discricionalidade do design latino-americano}

[...] La educación ideológica tiene una gran importancia para la formación de diseñadores; es fácil comprender que alguien encaminado a desarrollar trabajos como el diseño de objetos, de campañas de divulgación y educación masiva sobre aspectos de consumo, debe necesariamente tener un adecuado nivel ideológico y político (Espín, 1980b, p. 2).

A documentação exibe ideias em torno do que se compreende pelo exercício do design, com o claro interesse em marcar os limites do campo. Essas ideias estão sendo formuladas com duas características: por um lado, não estão sendo trabalhadas abstratamente, como quem tenta definir a epistemologia do campo e sim de forma a inscrever o design na área da tecnologia. Por outro -quiçá a partir daí-, essas ideias veem construídas em relação a uma critica das condições econômicas e sociais do contexto de onde é precisamente possível considerar a tecnologia como caminho para superar as dificuldades nacionais e daí o respeito pelas condições culturais que exigiam as circunstancias sociais. Em uma outra expressão -e como o design é compreendido como tecnologia para os autores-, a ideia de que ele é uma promessa para a mudança social. ${ }^{11}$

Porém, afirmando alguns tipos de enunciados é possível pensar que os autores daqueles documentos estavam pretendendo marcar os limites do campo ao responder à abstração 'o que é design?'. É interessante ver como essa definição parece escapar das suas mãos. As ideias presentes nesse primeiro grupo procuram se aproximar à compreensão do que é o curso, fazendo analogias com o sentido prático do seu uso social, defendendo a diferença com relação a ocupações parecidas, determinando áreas

\footnotetext{
11 Tema para uma outra dissertação. A geração que lidera esse processo é uma geração comprometida ideologicamente com essa mudança. Talvez isso faz com que eles não pareçam muito interessados nas reflexões teóricas do campo como tal, mas sim nas suas implicações praticas. Estavam na tarefa de encontrar as ferramentas para conseguir a mudança. A sentença de Marx nas Teses sobre Feuerbach e que ficou gravada na sua lápide em Londres pega aquele espirito que parece rondar as camadas de intelectuais latino-americanos durante as décadas meridionais do século 20, dentre eles a maioria dos fundadores da ALADI: "the philosophers have only interpreted de world in various ways. The point however is to change it".
} 
de desempenho e até querendo ressaltar as suas habilidades na realidade da América Latina.

Em geral, esse grupo de ideias sobre jurisdição e discricionalidade terminam sendo as que mais citações representam no total das ideias apresentadas na documentação. A forma de se aproximar dela será respondendo o que é design a partir da estratégia de dizer para que ele funciona. Nessa tentativa, os documentos vão configurando três grandes blocos de enunciados, relativamente autônomos entre si, que chamarei de 'tons' daqui para frente. ${ }^{12}$

O primeiro compreende aqueles que pretendem se aproximar das necessidades sociais em procura da sua resolução. 0 segundo defende que o design trabalha para o desenvolvimento tecnológico norteado pelas necessidades industriais. 0 terceiro tom vai justificar a função do design na satisfação das necessidades econômicas.

\section{O sentido... a sua função}

1.

Posso afirmar que os que conseguem expressar com maior claridade o primeiro bloco - desenvolvimento social- fazem parte da delegação costarriquenha e da delegação cubana. 0 tom dessa ideia pretende relacionar a função social do design com o bemestar das pessoas. 0 seguinte é um trecho do texto centro-americano

[...] [o] diseñador [...] como hombre nuevo [...] contribuyendo en la consolidación del Diseño Industrial como aquella disciplina vital para el desarrollo de la sociedad en pro del bienestar de los pueblos (Leiva, 1980, p. 4).

É o sentido de intervir na vida dos outros com o objetivo de melhorar a qualidade de vida: desde o impacto na vida coletiva e a resolução dos desafios que oferecem os problemas urbanos, concentrado nas condições habitacionais, as moradias, o saneamento, as condições da saúde, da aprendizagem, do transporte publico, etc., até chegar na reivindicação das condições de vida e trabalho dos camponeses. Preocupações que aparecem nas críticas econômicas do desenvolvimento regional desde os anos 1940, como tentarei mostrar mais a frente.

É a concepção do design como suporte para o desenvolvimento social e como promessa para mudar uma realidade precária. Ideia proposta pelas delegações

\footnotetext{
12 Quero chamar esses subgrupos de 'tons', compreendendo que eles são em realidade variações nos
} ênfases sobre o mesmo núcleo de ideias. 
brasileiras, colombiana, cubana e costarriquenha. Não que as outras delegações não expressassem essas preocupações, mas estas o fizeram como dimensões relativamente independentes.

Antes de continuar me parece importante mencionar uma latente diferença, percebida na documentação quanto a referência 'ao social'. É interessante ver como esses autores parecem mais ou menos divididos nas apostas sobre como compreender a ideia de 'população' e a partir daí, os impactos daquele desenvolvimento social, marcando diferenças no âmago fundacional da ALADI. A primeira -claramente a mais presente- aquelas ideias que defendem com contundência que 'esse grupo de pessoas' era compreendido pelas camadas marginalizadas do progresso social

[...] soluciones comprometidas con quien vive día con día los problemas [...] tenemos que plantear soluciones, es a la satisfacción de las necesidades primarias de las grandes mayorías marginadas de nuestro país (Rivera, 1980a, p. 11).

[...] penso num desenho industrial que vá fazer o calçado não essencialmente para exportar, e sem pra calçar metade da população brasileira [...] o $80 \%$ da população fica marginalizado não só pelo design: não tem sapato como não tem escova de dente, como não tem água para lavar a boca, como não tem esgoto (Ventura, 1977, p. 1).

Nesse contexto, esse tipo de ideias compreendem o marginal como um grupo em que estão incluídas pessoas afastadas dos impactos da modernização e apresentam uma certa mistura com o que os autores entendem por popular. 0 design funciona para elevar a qualidade de vida das pessoas que moram na marginalidade do sistema social, onde respira a chamada cultura popular... onde mora o realmente nacional... o profundamente latino-americano.

A segunda diferença sobre a população sugere uma ideia 'mais profissionalista' do problema. Se a perspectiva do social como marginal e popular poderia ser mais ideológica, essa outra seria mais técnica. Nesse grupo -menor do que o anterior quase em sua metade- se entende que a tarefa do designer é a satisfação das necessidades das pessoas vistas como usuários, já não como pessoas em uma situação social específica. Apesar da aparente abrangência do termo -o design não parece estar explicitamente reservado para as camadas populares, por exemplo-, essa perspectiva pode estar evidenciando um deslocamento do âmago do alcance do design. Para desenvolver essa ideia os autores incluem preocupações que não parecem estar finalmente focadas na resolução de necessidades das pessoas, e sim em situações relativas à percepção ou à 
ergonomia como fins. É como se o objeto de trabalho do designer fosse esse, enquanto o ser humano -virando variável dependente- aparece como uma desculpa inevitável. Simultaneamente, um relativo esfriamento ideológico e um claro rabisco dos objetos que estuda o campo. Uma grande diferença na hora de enxergar o design. Uma evidencia de pelo menos- duas ALADIs.

2.

Como mencionei, uma outra aposta vai acompanhar a ideia de definir o design como ferramenta do desenvolvimento social. Será a ideia do design em relação com o universo tecnológico-industrial. A diferença com o relativo equilíbrio na citação do tom anterior é notória. Enquanto as ideias do bem-estar e o melhoramento da qualidade de vida das pessoas está presente nos esforços por definir o design nos argumentos de pelo menos quatro das nove delegações nacionais presentes em Bogotá, as de desenvolvimento tecnológico, são expostas em bloco pelo Brasil e uma ou duas vezes por um dos documentos mexicanos, o que pode estar relacionado com as suas próprias conjunturas.

No caso do Brasil, além de uma histórica relação com a industrialização e as pautas da CEPAL desde os anos 1950, a década dos anos 1970 está caracterizada pelas políticas da ditadura militar que incluiu o design como um dos pontos da sua pauta para o desenvolvimento. Entre muitas outras coisas, seguramente isso obrigava que as justificativas do papel social do design transitassem sintonizadas com as expectativas tecnológicas-industriais. Ao afirmar que o design é tecnologia, ia se possibilitar o seu fortalecimento como campo. Teria aceitação social e era uma forma de ser incentivado pelos interesses governamentais que dificilmente os reprimiria -como sim acontecia com as artes e as humanidades seguindo o exposto por Couto (2008)-.

Está mais ou menos claro que nesse tom as definições sobre o que é design está tentando incluir o exercício da disciplina dentro do processo de configuração dos produtos, como mecanismo para racionalizar tanto as necessidades do consumo, quanto a eficácia da produção. Só tais racionalizações podem garantir o fortalecimento da indústria nacional. Eis que tais racionalizações só parecem possíveis mediante o design 
[...] para o desenhista industrial o conceito de produto está intimamente vinculado a sua utilidade e racionalidade [...] planejar um produto significa [...] determinar e enfatizar seus aspectos funcionais, normalizar, padronizar e compatibilizar componentes, disciplinar o emprego de matérias-primas e processos de fabricação [...] sempre que possível, através de uma produção desconcentrada o que inclusive permite substancial economia na sua distribuição (APDINS-RJ; APDINSPE; ABDI, 1979a, p. 6 e 7).

Agora, não é possível só intervir em todas as fases de produção de um objeto para conseguir o sucesso. A maioria dos documentos que estão defendendo esse ponto de vista, simultaneamente estabelecem uma participação direta dos designers no estabelecimento de réguas e políticas tecnológicas e industriais nos seus respectivos países... uma aposta pela mudança da realidade, onde o design -de novo- parece mais um assunto secundário

[...] o desenho industrial como parte integrante do suporte científico e tecnológico do país deve estar inscrito no planejamento, formulação e execução de políticas de ciência e tecnologia, que pretendam alcançar objetivos fundamentais como: criação de uma tecnologia industrial endógena; controle da importação de tecnologia; integração crescente das tecnologias importadas, indispensáveis [...] direcionamento da criação e implantação de tecnologia em relação às necessidades da população (APDINS-RJ; APDINS-PE; ABDI, 1979a, p. 7).

3.

Com alguma independência, essas funções do design nas expectativas tecnológicoindustriais consegue compartilhar determinadas concepções dele como instrumento da satisfação das necessidades econômicas dos países latino-americanos. Acompanhando o desenvolvimento social e o tecnológico-industrial, esse seria o último tom nesse primeiro grupo de enunciados. É interessante ressaltar que, assim como no caso das ligações entre design e tecnologia/desenvolvimento industrial, nesse caso também existe uma espécie de grande conglomerado por países. A compreensão do design no âmago das necessidades econômicas, aparece concentrado principalmente na Colômbia, com algumas menções na Costa Rica e em Cuba. ${ }^{13}$

Duas grandes concepções aparecem nessa perspectiva. Por uma parte, a aparente isolação cubana. Posso dizer que dado o seu modelo econômico, o seu funcionamento

\footnotetext{
13 Mais a frente tentarei expor a crítica que os autores fazem da realidade social como justificativa da mudança social. Aí, as necessidades econômicas são manifestas mas, a diferença do que estou querendo afirmar aqui, sempre estão ligadas de uma outra reivindicação: no geral, uma luta pela autonomia.
} 
depende da capacidade para se antecipar aos fatos, se ajustando às variações no que eles chamam de "economia de planificação"

[...] a partir del concepto de que "el diseño es la actividad de proyección creadora, científicamente realizada", queremos recalcar que la importancia económica fundamental del diseño, estriba en primer lugar en su papel de instrumento escencial de la planificación económica y en que es el mecanismo mediante el cual se garantiza la coordinación de la producción de bienes de consumo con el consumo (Espín, 1980a, p. 2 o realce é do texto original). ${ }^{14}$

O trecho é o primeiro parágrafo do segundo numeral da palestra feita por Iván Espín em Bogotá. 0 primeiro numeral desse documento é um tipo de introdução -uma pagina- no qual Espín está apresentando os antecedentes gerais da institucionalização do design em Cuba, que em realidade são elementos do cenário econômico e social da ilha. Menciono isso porque me parece interessante como essa apresentação é a introdução ao que se deve compreender por design em Cuba. Ainda geral, as contribuições do design para o funcionamento social, dependem estritamente da sua importância no esquema da planificação econômica.

Não consigo imaginar as implicações práticas que isso tem, no sentido de como é que o design pode conseguir concretizar algo assim. Porém, além de se é possível ou compreensível, o que me parece interessante é a importância atribuída à disciplina nesse cometido e o apoio que consegue pelo sistema político. Segundo Lucila Fernández (2005; 2008; 2012), as relações entre o planejamento industrial, o consumo e o governo cubano tinham estado presentes nos ideários jurisdicionais do design na ilha desde os anos 1960.15

\footnotetext{
${ }^{14}$ Essa ideia de "economia de planificação" aparece sistematicamente nos discursos dos cubanos relacionados com ALADI, principalmente aqueles inseridos na ONDI -escritório nacional de design-. Nas entrevistas feitas com Gisela Herrero (2015) e com Alejandro Ojeda (2015), essa ideia surgiu uma ou duas vezes quando falávamos do papel social do design na ilha.

15 Para deixar indicado, essa ligação pode se explicar pela presencia de Iván Espín. Nascido em Santiago de Cuba em 1935, Espín estudou arquitetura nos Estados Unidos, especificamente no MIT. É muito provável que lá, nos anos em que estudou, ele se sensibilizasse com a prática moderna daquilo que se estava conceitualizando como design. Todos sabemos da migração de nomes da arquitetura europeia para varias universidades norte-americanas, principalmente em Boston (MIT e Harvard), Chicago e New Heaven (Yale). Depois parece que Espín obteve uma bolsa UNESCO que lhe permitiu se aproximar aos debates europeus sobre ensino do design. Por outro lado, ele era irmão de Vilma Espín, líder política da Revolução Cubana, quem era membro do Comité Central e do bureau do Partido Comunista da ilha. Ela foi a esposa de Raúl Castro, nomeada usualmente, desde antes que ele ascendera ao poder, como "la primera dama de Cuba".
} 
Junto com essa particularidade cubana, a segunda concepção que pretende expor a função do design nas necessidades da economia, está estreitamente conectada com a chamada industrialização pela promoção de exportações. Várias delegações mencionam vínculos com essa linha. Desde o reconhecimento das funções práticas do Escritório de Desenho Industrial do Instituto Nacional de Tecnologia do governo brasileiro, até as confissões relacionadas com a promoção do design no México. Contudo, são dois documentos os que expõem essa ideia de forma autônoma. 0 primeiro, a que parece ter sido a palestra da delegação costarriquenha. Aí, a ideia de satisfazer a necessidade de ampliar os mercados externos ao tempo e ritmo do chamado consumo interno é uma das sete tarefas que o designer deveria ter na Costa Rica. 0 segundo documento é realmente contundente nessa perspectiva. É o que aparentemente foi a apresentação de Juan Buenaventura -que mencionei em paginas anteriores-. Ele aparece como convidado pela organização do evento, representando, não tanto a delegação de fundadores colombianos da ALADI, como sim o governo mesmo. Para ser preciso e mais ou menos justo com os fatos, dada a história do design industrial na Colômbia, mais do que a representação do governo, no final ele está significando uma das mais fortes linhas da história do design colombiano

[...] a medida que los países, especialmente aquellos en vías de desarrollo, incrementan la exportación de sus productos, se hace mas patente la necesidad de tecnificar los medios de producción, los procesos y materiales, así como los instrumentos de capacitación y perfeccionamiento de la mano de obra. Lo anterior significa que la técnica del Comercio Internacional debe fundamentarse hoy día no solo en factores de orden político, financiero o comercial sino también de orden técnico como son: el diseño del producto, su calidad y su empaque [...] es aquí donde el desarrollo del diseño industrial sigue respaldando al producto en su empeño de penetrar en los mercados extranjeros [...] Proexpo, podría sintetizarse en el lema, "Promoción de las exportaciones a través del diseño industrial, la calidad, el empaque y la capacitación" (Buenaventura, 1980, pp. 1, 8 e 10).16

Desse modo, o design como instrumento para a estabilidade do sistema político em Cuba, suportando o eixo do sistema econômico embasado na planificação. Design visto como ferramenta para conquistar o sucesso de produtos nacionais em mercados internacionais, com o qual eram puxadas ao tempo a indústria e a economia.

\footnotetext{
${ }^{16}$ As relações entre PROEXPO e a profissionalização do design colombiano são notórias. Esse escritório, pelo que se sabe, seguindo diretrizes de agencias internacionais, promove reuniões e ideias em torno do design desde finais dos anos 1960 (Buitrago, 2012).
} 


\section{Geografias}

1.

Um outro grupo de ideias aparece na documentação nessa tentativa de definição do que é design na América Latina. Nesse caso -um pouco mais amorfo- a estratégia argumental vai se expressando desde um nível muito mais pragmático, como definir as áreas de desempenho do designer em cada país, se complementando, já não na descrição da função do design -como nas paginas anteriores- e sim na enunciação de aquilo que o design não é -ou que não deveria ser-.

Poderia dizer que como unidade, os enunciados expõem as áreas de desempenho respondendo a dois grandes núcleos, que por sua vez transitam nos imaginários dos mais diversos intelectuais e profissionais latino-americanos daquelas décadas. Um deles seria uma aplicação das funções do designer no campo do desenvolvimento tecnológico, principalmente relacionado com as necessidades dos camponeses. Essa linha responde às problematizações gerais impulsadas pelas agencias internacionais, como por exemplo o PNUMA -Programa das Nações Unidas para o Meio Ambiente-. Como mostrei no capítulo anterior, esse escritório defende a intervenção na vida rural respeitando as condições de vida da povoação e promovendo fundamentalmente o principio de autonomia tecnológica ${ }^{17}$

[...] industrialización de la producción agropecuária [...] en un país que por un lado presenta un potencial agropecuario elevado, y por otro, escasos recursos humanos localizados mayoritariamente en áreas urbanas. También el campo de la construcción y los servicios (equipamiento urbano y rural, transporte público educación, salud) (Colmenero \& Nápoli, 1980, p. 4)

Mais ou menos ligado, é notório que a segunda parte do trecho anterior está defendendo outro cenário. Esse seria precisamente o segundo núcleo. Ideias que provem das críticas ao desenvolvimento que vários frentes vinham fazendo visíveis desde os anos 1950. A CEPAL, por exemplo, já tinha diagnosticado nos finais dessa década, que a sua proposta de industrialização dos anos 1940 mostrava um gigantesco problema muito a pesar dos indicadores de crescimento industrial. Dai que os indicadores de marginalidade se dispararam convertendo os assuntos de infraestrutura urbana no

\footnotetext{
17 “[o] desarrollo tecnológico, ha producido diseños de productos, sistemas e implementos para pequeñas empresas y para el sector rural que bien podrían ubicarse dentro del campo, hoy amplio, del diseño industrial" (Gómez, 1980, p. 5).
} 
centro de preocupações e receitas internacionais e, claro, no âmago das pautas dos governos e dos discursos populistas na região. 18

Essas denúncias e tais recriações de ideias iam e vinham nos cenários latinoamericanos dos anos 1960 e 1970, principalmente nos cenários acadêmicos nos quais estavam se formando a grande maioria dos autores desses textos entregues em Bogotá. Então, a um grande flagelo regional e a uma necessidade por justificar a importância de uma disciplina em nascimento, uma solução direta: um área de atuação. De tal forma, tanto o desenvolvimento tecnológico para atividades agropecuárias, quanto o trabalho nas condições habitacionais que estava puxando o processo de urbanização, os dois se convertendo em áreas de trabalho do design industrial na região.

2.

Agora essas áreas de desempenho estão permanentemente complementadas por uma espécie de justificativa que arranha níveis mais elevados de abstração. Um primeiro degrau nessa subida -que representa a particularidade do Brasil nesse cenário- está relacionada com uma luta de prestigio do nível da profissão por causa da terminologia. Esta mais ou menos claro que quando um curso é institucionalizado nas expectativas modernas, inicia uma luta com aquilo que ocupava o seu lugar na sociedade, com o proposito de se estabelecer -um pouco a ideia do poder simbólico de Bourdieu (2014)-.

No caso brasileiro, por causa da língua, existe mais um elemento quando comparadas as generalidades com o resto da América Latina que pode me ajudar com o argumento. 0 termo original com que foi conceitualizado o curso nesse país está diretamente relacionado com uma técnica: o desenho. Isso não acontece nos países que falam espanhol, dado que nesse caso existe um termo mais ou menos autônomo que recolhe o sentido: el diseño.

Ainda que a reivindicação seja feita sobre a necessidade por diferenciar o ato de desenhar da atividade de designar, nela pode estar respirando uma reivindicação relativamente classista, por parte desses filhos da classe média e alta que estavam tendo acesso à educação superior e que eram os autores desses documentos no Brasil. $\mathrm{O}$ ato de

\footnotetext{
18 Entre vários espectros percorrendo sobre a região, estava a ideia de uma grande parte dos norteamericanos que -em meio da Guerra Fria e da paranóia que disparou o triunfo do comunismo em Cubatinham se convencido de que a marginalidade era caldo de cultivo de contestação comunista na América Latina. Detalhes disso são apresentados por Azevedo no seu estúdio dos Corpos de Paz no Brasil (Azevedo, 2008).
} 
desenhar ou traçar, quase pode ser feito por qualquer pessoa. Pelo contrário designar, sugere uma atividade racional, abstrata que exige preparação o que por sua vez requer grandes inversões de tempo e até dinheiro na aquisição. Na luta pela distinção social, o esoterismo que supõe o conhecimento especializado não parece negociável na frente do que é aprendido de forma espontânea. ${ }^{19}$ Assim, era necessário mostrar a complexidade do que significa e do que implica fazer design -naquela época desenho-. Brasil muda de desenho para design nos anos seguintes deixando uma pegada que na verdade é um sintoma dessa luta pelo prestígio.

Boa parte dos enunciados que pretendem se aproximar à 'definição' do que é design, estão cientes da necessidade de conquistar esses limites na busca pelo fortalecimento do campo nas estruturas da sociedade, como já mencionei várias vezes. De definir o lugar que ocupa nas estruturas acadêmicas, nos órgãos de promoção e difusão e claro, a relação que deve estabelecer com a sociedade. Tudo mediante a sua relação com o Estado, no mecanismo da Matriz Estado Centrica que governa na América Latina naquele momento.

Como segundo degrau, acompanhando as buscas pela distinção, foram estabelecidas diferenças com áreas do saber que se ocupavam anteriormente de coisas específicas ou relacionadas com a discricionalidade do design. É esperado que na luta pela formação do campo, os autores tenham traçado divisões com outras ocupações, sobre tudo, nesse caso, e muito particularmente, contra disciplinas mais velhas, algumas delas -como a arquitetura- matrizes do design no contexto das histórias nacionais. Os argumentos para defender essa cisão são realmente aparentes. Tudo parece uma estratégia para fortalecer o campo e lutar pela sua soberania

[...] nem a arquitetura, nem a engenharia, nem a publicidade -profissões até então responsáveis pelo produto industrial desenhado no Brasiltinham facilidade em resolver, tratando-se de matéria especializada, tradicionalmente fora do âmbito de qualquer dessas atividades, exercidas já há mais tempo no Brasil (Redig, 1979, p. 1).20

\footnotetext{
19 Esse debate é o centro das discussões de uma linha da sociologia das profissões. Sugiro revisar o trabalho de Eliot Freidson (2001), Magali Larson (1977), Andrew Abbott (1988), Julia Evetts (2003), Harold Wilensky (1964) e/ou Ernest Greenwood (1957).

${ }^{20}$ No escrito não se sabe porque esses cursos não tinham a facilidade de resolver os problemas de percepção e codificação de mensagens visuais para as vias e terminais de transporte urbano -o contexto da citação no documento-. Se sabe sim, que esse é um problema complicadíssimo e urgente por se intervir; se sabe pelo tom exposto por Redig no documento e não necessariamente pela existência de um argumento que o respalde. Também se sabe que a sua intervenção supõe o trabalho de um saber especializado; esotérico como falaria Eliot Freidson (2001). Claro!, o especialista deve ser o designer e toda a cadeia do enunciado se fecha. Ainda bem que o Governo do Estado do Rio de Janeiro criou o núcleo
} 
$\mathrm{Na}$ ausência de argumentos por um lado e da apologia constante sobre a existência desse saber -que responde ao chamado da história-, parece respirar a aceitação social materializada institucionalmente como propósito prático. Com isso se garante o fortalecimento da disciplina enquanto se obtém o almejado prestígio social

[...] para o CNPq, Desenho Industrial pertence à área da arquitetura e para o CAPES à área de artes. Coloca-se como sugestão, o Desenho Industrial seja reconhecido como área específica de saber [sic] (APDINS/RJ, 1978, p. 6). ${ }^{21}$

Tais menções eram acompanhadas por sugestões do que seria design em função de ressaltar que design não era considerado arte. Nesses documentos não existe uma afirmação explicita sobre isso. Contudo, a alusão está aí, no ar, marcando coincidentemente um lugar comum herdado da Arquitetura Moderna, quando por sua vez se emancipou do senhorio das Belas Artes nos finais do século 19. Em certo sentido, essa mesma bandeira vai se levantar para defender a forma como o design responde a esse chamado histórico

[...] para ello debería tratarse de difundir el diseño industrial no sólo como una actividad que encuentra su lugar de expresión en una galería de arte, sino como una actividad profundamente integrada al esquema productivo del país (CADI, 1980, p. 2).

Não que o objetivo fosse definir o design industrial como parte da engenharia, mas claro, não era defini-lo como arte. 0 objetivo parecia ser afastá-lo das práticas artísticas para se aproximar das áreas relacionadas com as expectativas produtivas do país. 0 porquê? 0 como? Tais perguntas não eram incluídas na preocupação quando definir o design era o propósito. Os autores mencionaram ideias próximas a essas ligações, que mais a frente tentarei mostrar.

\footnotetext{
para atender esse gravíssimo problema! E ainda bem que já existia um saber que podia dar conta de semelhante situação! "o desenvolvimento desse núcleo [designers da ESDI vinculados à Secretaria de Transportes] se deu também, particularmente, em função da necessidade de um novo saber" (Redig, 1979, p. 1).

${ }^{21}$ No Brasil, o CNPq (Conselho Nacional de Desenvolvimento Científico e Tecnológico) vinculado ao Ministério da Ciência, Tecnologia está encarregado de fomentar a pesquisa no Brasil (CNPq, 2015). Por sua parte a CAPES (Coordenação de Aperfeiçoamento de Pessoal de Nível Superior), vinculada ao Ministério de Educação, foi fundada em 1951 para "assegurar a existência de pessoal especializado em quantidade e qualidade suficientes para atender às necessidades dos empreendimentos públicos e privados que visam ao desenvolvimento do país" (CAPES, 2015).
} 
3.

A abstração anterior me permite expor o maior nível de estado gasoso dos esforços em definir o que é design nesse grupo de ideias -um tipo de ápice nos degraus percorridos-. Para alguns desses autores, o design está estreitamente relacionado com o conhecimento e a transformação da realidade, assim como da solução dos problemas sociais. Se -por exemplo- para as relações entre design e arte que mencionei acima não existem enunciados claros que permitam compreender os argumentos, neste outro nível é evidente a inexistência de uma aproximação argumental para relacionar o design com tais compromissos. Talvez o enunciado que mais pode resumir esse nível de ideias seja do costarriquenho Mario Leiva na sua palestra no congresso em Bogotá “¿Será acaso el diseñador de hoy un miembro aislado de ese hombre nuevo? ¿O será el diseñador de hoy uno de lo primeros eslabones de esa búsqueda constante y tenaz?" (Leiva, 1980, p. 2).

A pergunta supõe uma abstração enorme. Dadas as poucas precisões conceituais no momento de se aproximar na definição do design, assim como a estratégia de delimitação do campo mediante o uso de analogias e de negações -o que não é-, me parece que essa abstração evidencia um esforço de defender um campo ainda indeterminado. A única opção é levantar bandeiras e estandartes como mecanismo de defesa ideológica do território.

\section{O designer latino-americano como o protótipo de homem ilustrado}

1.

Nesse evidente esforço em definir o design, vários dos autores dos textos vão trilhar ainda um outro caminho. A proximidade sobre procedimentos e o que atualmente se chamaria "competências" dos designers latino-americanos, serão uma terceira estratégia que acompanharam as anteriores tentativas de definição. Apesar das relativamente poucas citações -quando comparadas com o volume das duas anterioresnesse tipo de debate estavam envolvidos explicitamente mais da metade das delegações presentes em Bogotá.

Nessa linha, vale lembrar novamente uma ideia do costarriquenho Mario Leiva quando está procurando uma definição do que significa, ou implica, o designer no cenário da América Latina de finais dos anos 1970 
[...] el mismo diseñador firmando su presencia como hombre nuevo y contribuyendo en la consolidación del Diseño Industrial como aquella disciplina vital para el desarrollo de la sociedad en pro del bienestar de los pueblos (Leiva, 1980, p. 4).

Como seria concretizado semelhante chamado? Do que pode se deduzir dos escritos: por meio de um conhecimento estrito, completo e crítico da realidade social na que vivem. ${ }^{22}$ Essa questão parece sintetizada na oportunidade de dominar os conhecimentos sobre as circunstâncias sociais. É conhecer "os aspectos sociais, econômicos e culturais do país, para atender às reais necessidades do homem brasileiro" como afirmava Anamaria de Morais (1980a, p. 1), por meio de uma refinada consciência social e uma clara postura política.

A generalidade proposta pelo costarriquenho Leiva dá resposta procedimental de como é que iria se atingir esse objetivo. O conhecimento dos problemas nacionais, relacionados com a ciência das condições econômicas, sociais e tecnológicas do seu contexto é um primeiro degrau. Esse, por sua vez, vai ser possível de dominar graças ao pensamento crítico sobre a realidade. Talvez dessa ciência crítica, só mais um degrau para poder denunciar aquele "capitalismo selvagem" que tanto ameaça a identidade e a autonomia dessas sociedades. Muito provável que, ao chegar nesse ponto, o designer latino-americano estivesse se afirmando como o homem novo... como a encarnação da utopia.

Traço esse enunciado como uma escada ascendente, querendo desenhar a ideia da elevação dedutiva, seguramente embaixo do meu feitiço da metáfora que Marx expõe com tanta lucidez. ${ }^{23}$ No meu caso, do que percebo na documentação como uma ascensão de um certo 'nível concreto' para uma notória abstração. Porém, o que parece mais sensato é compreender que não é tanto uma ascensão como uma descida. É dizer, aquele primeiro degrau que denominei 'a ciência das condições do contexto', parece ser na realidade o primeiro passo para dentro. De tal forma que o pensamento crítico é

\footnotetext{
${ }^{22} \mathrm{~A}$ ideia percorre os cantos dos diversos documentos até naqueles textos que foram redigidos em outros momentos e por outros motivos. Nesse momento me lembro das definições de Rómulo Polo para justificar a criação do programa de design industrial na Pontificia Universidad Javeriana de Bogotá em 1976 ou dos argumentos de Pablo Robles configurados em torno do perfil dos designers mexicanos do curso da Universidad de Guadalajara em 1977 -no capítulo anterior citei trechos desses dois documentos-.

23 "en la ciencia no hay calzadas reales, y quien aspire a remontar sus luminosas cumbres, tiene que estar dispuesto a escalar la montaña por senderos escabrosos" (Marx, 2008, p. Prólogo da edição francesa em 1872).
} 
considerado como uma habilidade adquirida dentro do designer, que repousa na base da forma de pensar e se relacionar com a realidade.

0 pensamento crítico naquele momento, valorizado por esses intelectuais como o eixo a partir do qual se percebia a possibilidade da mudança social. Mas, como mencionei em páginas anteriores, um pensamento crítico que não vê a especulação teórica como fim, e sim, a intervenção material da vida das pessoas como vocação... que parece não querer mais interpretação da realidade, e sim a sua mudança... como se o epitáfio marxista no seu túmulo falasse ao ouvido de uma geração. Ao final, segundo os autores, resolver as carências da população, assim como as necessidades tecnológicas para fortalecer a indústria e acompanhar os processos de fortalecimento econômico, são as linhas do 'chamado' às que devem acudir o designers latino-americanos.

2.

Esse impacto concreto pode se dar por via de algumas habilidades e características no perfil do designer, significativamente diferentes das outros atores sociais. Em parte, o que os mexicanos e brasileiros realçam como interdisciplinaridade e que claramente procura o impacto na vida das pessoas, visando a autonomia e a libertação cultural.

Para complementar, quase homologando o design como um tipo de procedimento -que supõe ser ordem algorítmico-, está-se garantindo o sucesso do seu trabalho, assim como a abstração do seu chamado. Definir o design pela forma como ele opera, e aproxima-o à ordem receituária do passo a passo, permite justificar a necessidade de participação dos designers em toda as 'etapas' de concepção e materialização de um objeto -mercadoria, sistema, etc.-. Já não a justificação do design por sua função, mas por uma latente reivindicação da sua importância pelas maneiras como procede.

Tal tipo de procedimento pode estar reivindicando uma classe de aproximação ao conhecimento, que está ligado às concepções ideológicas por meio das quais era criticada a realidade e concebido o sentido da vocação profissional: a prática e a intervenção que é uma ode à mudança do mundo. 0 reconhecimento da necessidade no contexto e a concepção da solução podem se caracterizar como um abordagem indutiva ao conhecimento. Abordagem que lembrará possivelmente a metáfora marxista do cume que citei parágrafos atrás. Enfoque no contexto que permite conhecer as condições da realidade, quase por fora da teoria. Em Cuba, parte dessa lógica é exposta no sentido de que o designer 
[...] trabaja en diferentes industrias como obrero para conocer los problemas generales de la economía, así como las dificultades de cada puesto de trabajo relacionado con su problema concreto de diseño (Espín, 1980b, p. 6).

A aproximação indutiva vai acabar reivindicando o que muitos querem atribuir ao design: a chamada metodologia do projeto onde tudo o saber é equacionado. 


\title{
Design e circunstâncias
}

\begin{abstract}
[...] em nossa opinião seria indispensável que um Currículo Mínimo de Desenho Industrial estivesse em sintonia como as características e as necessidades contextuais básicas brasileiras. Por esta razão, discordamos das orientações pedagógicas que tendem encaminhar o aluno apenas para as formas mais complexas da produção industrial, próprias dos países desenvolvidos (APDINS/RJ, 1978, p. 9).
\end{abstract}

A documentação entregue em Bogotá também exibe uma série que, por sua conta, pretende usar o caminho justificativo do design, para defender um claro nacionalismo. Um viés latino-americano que pode ser tão antigo como a fundação mesma das repúblicas na região. Na documentação existe outro grupo de ideias que são tratadas como postulados subsidiários dele. Assim, quando é levantada uma preocupação sobre a técnica e a tecnologia, esses enunciados constantemente chegam à resposta dos problemas sociais da região, assegurando a resolução do problema maior: a dependência dos nossos países com as sociedades desenvolvidas.

Percebendo isso, decidi tratar as reivindicações nacionalistas e as menções sobre técnica e tecnologia como series em um bloco só. De tal maneira, as reflexões desses dois blocos, se convertem em um grupo que recolhe uma terceira parte dos enunciados presentes na documentação total, sendo assim o segundo grupo na sequência, logo da jurisdição e a discricionalidade do design que tratei na parte anterior.

Como grupo, por sua vez essas ideias se configuram em torno de uns cinco ou seis eixos, todos organicamente subsidiários da conquista da independência latinoamericana 'daqueles que não querem que a região crie a sua própria realidade'. Assim, todo esse bloco argumental parece uma aproximação para poder romper com o cordão umbilical da dependência com os países desenvolvidos, principalmente -claro- com os Estados Unidos. 


\section{Quebrar o imperialismo}

1.

Para uma tendência crítica como essa, o rompimento com as relações históricas de dominação -preceito que pode se extrair dos argumentos-, deve ser o grande propósito pelo qual exista o design na América Latina; de fato, deve ser o grande propósito pelo qual seja feito qualquer esforço intelectual na região -político, artístico, científico, técnico, etc.-. Esse propósito dá sentido às reivindicações maiores, que num nível elevado de abstração parecem interessadas em marcar o caminho para a mudança social que com tanta frequência se repete nos argumentos.

As reivindicações mais gerais sobre as circunstâncias nas quais são criadas as obras humanas, parecem se concretizar na análise sobre o ethos técnico, acadêmico e político do científico latino-americano, relembrando críticas como as que faz o argentino Oscar Varsavsky. Para ele existia uma permanente preocupação naquele olhar inocente que pretendia encontrar 'no norte' a linha guia para o desenvolvimento do pensamento local. Criticava tanto a descontextualização das concepções e produtos impostos sobre as circunstâncias, quanto a domesticação intelectual dos acadêmicos latino-americanos por aqueles dos países desenvolvidos, pois era uma manifestação do imperialismo cultural que oprimia a região. Disse Varsavsky em 1969

[...] es natural pues, que todo aspirante a científico mire con reverencia a esa Meca del Norte, crea que cualquier dirección que allí se indique es progresista y única, acuda a sus templos a perfeccionarse, y una vez recibido su espaldarazo mantenga a su regreso -si regresa- un vínculo más fuerte con ella que con su medio social [...] es un tipo de dependência cultural que la mayoría acepta con orgullo (Galafassi, 2004, p. 2).

Ainda que grande e relativamente abstrata, a abordagem desse grupo de ideias vai sustentando a crítica nos textos apresentados em Bogotá, mesmo que nem Varsavsky ou qualquer outro tenha sido referenciado. ${ }^{24}$ Parece-me que o cubano Iván Espín é quem conecta com maior claridade essa dimensão

\footnotetext{
${ }^{24}$ Já anunciei que Varsavsky é um das três citações feitas naqueles 35 documentos. É referido pelo engenheiro colombiano Raúl Gómez, como epitáfio de entrada na sua palestra.
} 
[...] hay que comprender que el diseño [...] actúa sobre los consumidores produciendo y reproduciendo el tipo de consumidor adecuado al modo de producción [...] es utilizado como elemento esencial de colonización cultural, ideológica y tecnológica de parte del imperialismo [...] promueve tanto ideologías y modos de vida, como estructuras tecnológicas contrarias a nuestros intereses (Espín, 1980a, p. 4 e 5 o realce é de Espín).

Esse era um caminho bem diferente do que tomaram a maioria dos argumentos brasileiros nesse ponto. Se Espín abordou a crítica da autonomia e o design a partir do circunstancialismo -o que é feito na compreensão das circunstâncias, com o que as circunstâncias oferece- os documentos brasileiros assinalam -ainda muito timidamente- o problema da dependência dada a presença das multinacionais no país... claramente um eco das críticas econômicas que circulavam na América Latina na época, tanto cepalianas, quanto de matriz comunista

[...] o que é ainda mais grave é que entre estas 7 empresas, a maioria são filiais de multinacionais instaladas na região em função dos incentivos fiscais e do baixo custo da mão-de-obra local, com sua produção voltada basicamente para outros mercados e utilizando tecnologia sofisticada e importada, com índices baixíssimos de utilização de mão-de-obra e praticamente nenhuma utilização de profissionais voltados para o desenvolvimento de produtos (Nascimento, 1979, p. 5). ${ }^{25}$

$\mathrm{Na}$ diferença do argumento apresentado por Espín, os documentos brasileiros parecem flertar com uma sentida necessidade de determinar políticas tecnológicas para o país. A estratégia desses argumentos parece ser o uso de dados e até narrativas que estavam instaladas naqueles discursos críticos das diferentes agências que na época avaliavam os processos de modernização na região. A inexistência de uma problematização em torno do design é evidente nesses trechos. ${ }^{26}$

De tal maneira, um primeiro matiz dessa necessidade em romper com o externo se estabelecia sobre uma base relativamente abstrata. As denúncias de intervenção

\footnotetext{
250 dialogo que susteve a Teoria da Dependência de Fernando Henrique Cardoso e Enzo Faletto dentro da CEPAL, com a linha heterodoxa do comunismo de André Gunder Frank por exemplo, é nutrida e muito dinâmica nos anos 1960 e 1970 na região, se convertendo em uma das matrizes mais fortes de difusão do pensamento latino-americano "esta resulta decisiva [...] pensar el mundo no como un conjunto de Estadosnación relativamente independientes los unos de los otros [...] sino vinculados entre sí por relaciones asimétricas: relaciones de dependência y subordinación" (GEL, 2015, p. 5).

26 "opção árdua, diga-se de passagem, num país cuja política econômica tende a favorecer o desenvolvimento das multinacionais em detrimento do médio e pequeno empresário" (Escorel, 1976, p. 3). "Como um quarto aspecto ressaltamos o controle de grande parte da indústria está na mão de empresas estrangeiras, que trazem a tecnologia e o "design" de seus produtos prontos, o que implica na evasão de divisas" (APDINS/RJ, 1978, p. 2).
} 
empresarial e cultural marcam essa linha. Ou, para mencioná-lo num tom mais ideológico -talvez mais próximo do tom dos documentos-: a determinação do imperialismo na região, tanto econômico industrial -na figura das multinacionais-, quanto cultural, na dominação dos apetites, gostos e imagens nacionais, permite marcar dois pontos gerais, que justificam os esforços por romper com as dependências externas. 0 design apenas aparece graças às ideias do cubano Iván Espin.

2.

Acompanhando essas matizes, posso realçar a presença de enunciados que pretendem problematizar as relações entre a tecnologia, o desenvolvimento e a autonomia. Ainda no nível da reivindicação política, esse bloco de ideias parece interessado em concretizar as problemáticas latino-americanas e o levantamento nacionalista em torno do que significa e implica a tecnologia para os projetos nacionais de desenvolvimento.

o Gráfico 1 exibe os agregados correspondentes com o volume de enunciados sobre esse bloco de ideias. Essa proporção, meramente ilustrativa e aproximativa, permite comparar a partir da quantidade de vezes que uma delegação menciona ideias relacionadas com o tema. ${ }^{27}$

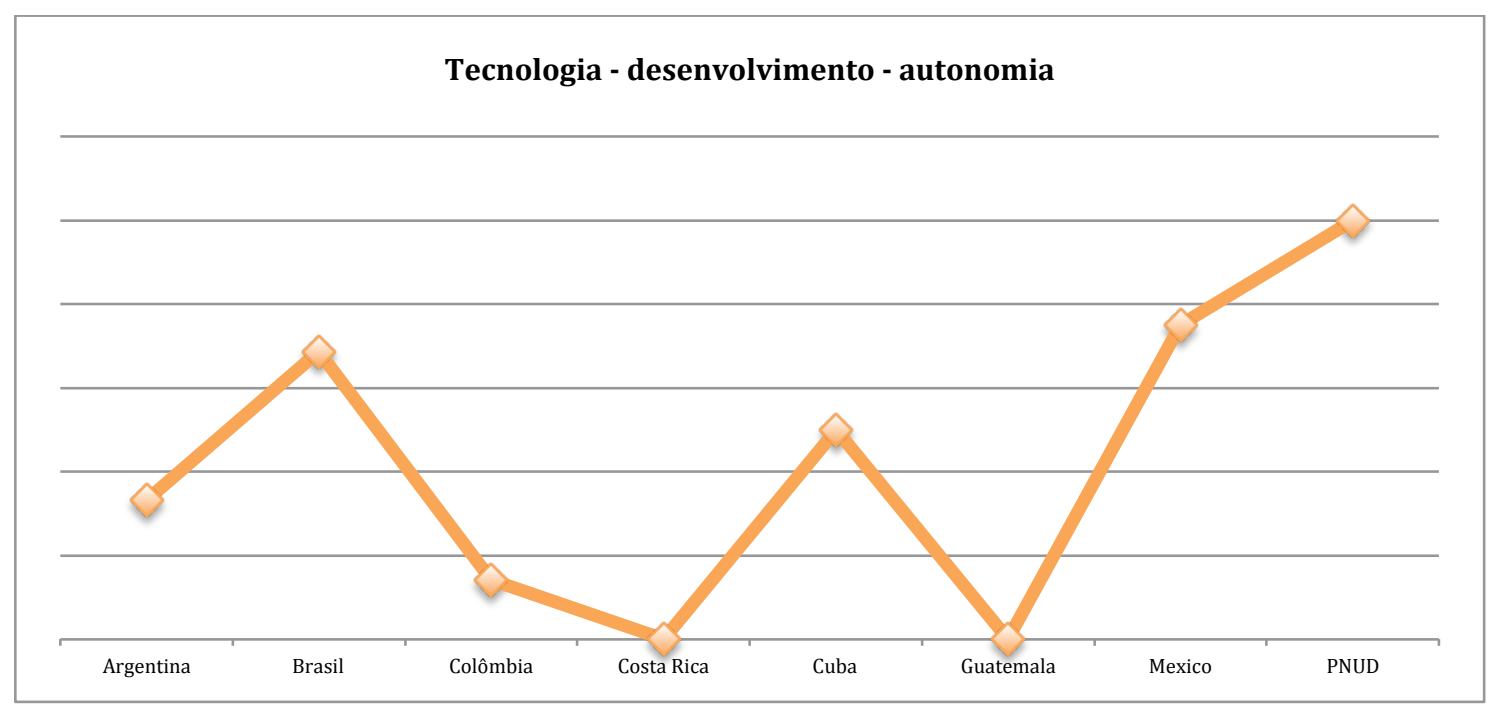

Gráfico 1. Comparação proporcional de menções a ideias sobre Tecnologia - desenvolvimento autonomia, desagregadas na documentação de cada delegação.

\footnotetext{
27 As tendências que mostra o gráfico se correspondem com o principio de porcentagem. Porém, dado o tratamento estritamente qualitativo das fontes, o preceito que agrega as tendências não é formalmente estadístico. 0 gráfico não pretende mais do que ilustrar tentativas proporções e não agregados porcentuais. Isso tudo explica o porque na gráfica não existe dimensão no eixo 'y', por exemplo.
} 
É interessante ver como se comportam as menções. Os documentos que traçam paralelos entre tecnologia, desenvolvimento e autonomia, são escritos por mexicanos, brasileiros, cubanos, argentinos e colombianos. Nem a Costa Rica, nem a Guatemala mencionam quaisquer ideias sobre o tema. Por sua vez a palestra feita por Guandalini agregado do PNUD em Bogotá em 1980- aponta sistematicamente para essa direção. Realço essa questão desde já antecipando que a aprofundarei na última parte desse capítulo. Gostaria que o final da curva desenhada nessa parte do gráfico acompanhe mentalmente as imagens do leitor enquanto apresento os meus argumentos daqui para a frente.

A estrutura argumentativa dessas ideias percorre uma certa generalidade: ela se apresenta a partir da denúncia dos grandes problemas da realidade nacional e regional das dinâmicas tecnológicas. Como são problemas que claramente devem ser superados, é mais ou menos automático que os autores vislumbrem estratégias de solução, propondo caminhos pelos quais seria possível pensar na mudança. Claro, dentro dessas estratégias estava inserido o problema das tecnologias, notoriamente abordados no jargão da época -preocupações com a transferência tecnológica, tecnologia apropriada, etc.-, para finalmente chegar no design como ferramenta mais lógica para conseguir consertar toda a cadeia causal. Como um meio poderoso, que permite sonhar com a independência dos nossos povos.

Na fórmula defendida pelos autores, de um lado as ligações técnicas estavam vinculadas fortemente aos produtos finais, assim como com as possibilidades para a sua materialização e reprodução. De outro, estavam ancoradas no consumo, nos costumes, no gosto e nos demais acordos tácitos que eles traziam como significantes. Tanto em uma ligação quanto na outra se empenhavam na determinação das necessidades, assim como os meios e as formas para resolvê-las... estava se garantindo a dependência cultural. No cenário da Guerra Fria da Cultura -para usar o mote de Saunders (2008)uma estratégia para prolongar a dominação

[...] la tecnología, la maquinaria y los productos que se generan con estas, están diseñados para satisfacer una necesidad concreta en base a patrones socio-culturales, climatológicos, ergonómicos y tecnológicos, propios de la sociedad en la que se genera dicha necesidad [...] así por ejemplo [...] la necesidad imperiosa que existe en Inglaterra de desarrollar diseños eficientes para calefacción de ambientes, en Quito, Ecuador [...] es exactamente la contraria. La idea de importar tecnología y con esto pensar que se obtendrá el tan deseado "desarrollo" es una utopía; la tecnología a la venta de los países industrializados es obsoleta y anticuada la mayoría de las veces para su lugar de origen, es así que el 
país que la importa siempre estará varios pasos atrás en el avance tecnológico propio y en el mercado internacional; además de la dependencia que se genera tecnológicamente hablando, se genera una dependencia económica por concepto de mantenimiento, adiestramiento del personal operario, pago de regalías, royalties, asesoramiento técnico, etc.; y a la larga esto desemboca en una dependencia cultural [...] el industrial que los produce habiéndolos importado tiene su venta garantizada, puesto que se encuentra apoyada por los medios masivos de comunicación como la televisión, la prensa, cine, que a su vez son importados en un alto porcentaje. Así el pueblo importador de dicha tecnología en su afán de salir del subdesarrollo sólo genera más subdesarrollo por este camino, para beneplácito de los países desarrollados (Rivera, 1980b, p. 1 e 2).28

Essas denúncias permanentemente dialogavam com os anunciados problemas nunca medidos- da submissão do conhecimento por causa da tecnologia importada exposto uma e outra vez como know-how-; do desequilíbrio das balanças de pagamentos; e dos viciados processos de perpetuação da dependência econômica, cultural e política. Como falei, é difícil encontrar uma linha argumental relativamente empírica dessas ligações que permita compreender o sentido de tais apostas. A maioria das vezes, essas teses estão sendo propostas com altos níveis de abstração e altas doses de carisma. Daí que seja relativamente esperado que tais problemas se relacionem com as ameaças maiores do voluntarismo do que falava Robles -naquele texto que apresentei no capítulo anterior- e que Sennett chama de solidariedade. ${ }^{29}$

Ou seja, em meio à indeterminação do caminho seguido pelo argumento, a abstração daqueles enunciados termina mexendo de forma igualmente indeterminada com a reivindicação da estratégia de resolver os problemas locais a partir do estudo sensível do contexto e por meio das possibilidades que oferecem os locais... da América

\footnotetext{
${ }^{28}$ Nessa perspectiva são notórias as denuncias sobre a realidade tecnológica nacional na expectativa das políticas governamentais como projeto social, ou pelo menos da forma como eles compreendiam tal assunto. Com algumas variações, tais ideias são principalmente defendidas nos documentos brasileiros, cubanos e mexicanos, girando em torno do apontamento dos problemas das práticas de importação tecnológica. Como é usual ao longo da documentação, tais diagnósticos não são exatamente argumentos construídos. Parecem mais que qualquer coisa um exercício de reflexão da experiência em formato de ensaio. Quiçá como os autores não são exatamente acadêmicos consagrados, esta mais ou menos claro que os enunciados são um esforço por precisamente dar perspectiva à experiência que já acumulavam, e que se fundia com uma treinada crítica das condições do seus contextos, como opinião política de um certo nível.

${ }^{29}$ No capítulo anterior mencionei que ao contrario do que defende o sentido comum, Sennett (2012) diferença a solidariedade da cooperação. Na primeira existe um olhar que reproduz a estratégia do "nóscontra-eles" usado pela esquerda contra as perversões materializadas pelo capitalismo. Uma certa verticalidade na compreensão do outro, que não permite fugir do paternalismo ou do voluntarismo na ideia daquele documento de Pablo Robles no Interdesign'78. A cooperação está mais ligada de um olhar horizontal... de pares que trabalham por conquistar um alvo.
} 
Latina para América Latina... um caminho de reivindicação da autonomia da região que tem longos antecedentes. A passagem que citei do texto do mexicano Sergio Rivera mostra todos esses elementos em diálogo.

\section{3.}

Independentemente da natureza desses argumentos, os autores dos documentos não só não duvidavam ao considerarem aqueles males como obstáculos do desenvolvimento, mas propõem algumas rotas para tentar superá-los. Alguns deles mencionavam a abstração do envolvimento do designer nos debates e as problemáticas da tecnologia e a dependência, um pouco na linha defendida da formação profissional que arranha a erudição e que abriga os ideais do homem ilustrado como habilidade do designer.

Alguns outros, brigavam com a ideia de estabelecer uma pauta racional que permitisse debater e estabelecer uma política nacional de tecnologia, na qual o design fosse visto como uma das rotas mais efetivas para conquistar o desenvolvimento e o bem-estar. Essa política parecia ser norteada pelo estabelecimento de apostas claras sobre a criação, a compra ou a apropriação da tecnologia na realidade nacional. Em meio ao debate sobre tecnologias e subdesenvolvimento -promovido pelas agencias internacionais e os escritórios ligados a ONU-, era tal vez uma maneira como, por exemplo, os brasileiros se posicionavam

[...] 1) Definir uma política tecnológica concreta e factível, a partir das necessidades reais da população brasileira. 2) Prover a base institucional para criação de tecnologia própria e criar mecanismos de estímulo e defesa desta criação. 3) Estabelecer critérios para a seleção e compra de tecnologia estrangeira (APDINS/RJ, 1978, p. 6).

Assim mesmo aparece o caminho que pretende desenhar a criação de mecanismos para mapear as diferentes formas de produção nas realidades nacionais: o popular ou o artesanal. Nesse ponto, dependendo de uma certa ênfase, as delegações poderiam parecer mais interessadas na absorção de técnicas, procedimentos e inovações dentro do ritmo do desenvolvimento tecnológico moderno -matiz brasileiro- ou, na outra mão, uma forma para detectar e com um certo respeito por elas, protegê-las como parte do significado essencial da cultura... como patrimônio. Esse último presente com mais ênfase nos discursos colombianos, mexicanos, costarriquenhos e até guatemaltecos. Uma diferença de enfoque que ainda compartilha o eixo, marca uma outra grande 
distância na maneira de compreender os problemas relacionados com tecnologia e cultura

[...] Es decir, los argumentos y las cosas que nos podría interesar discutir, no eran los de la mayoría. Nosotros [os argentinos] éramos una minoria en realidad, [...] ¡no tiene sentido hacer una asociación de diseño industrial, donde el $80 \%$ de los membros no pasaron la artesanía!, decíamos nosotros. Nos resultaba medio raro. Bueno, lo hicimos, fuimos, discutimos y dijimos la nuestra y todo, y la gente nos respetó (Napoli, 2016).

À perspectiva de modernização a todo custo dos sistemas de resolução, se contrapõe o olhar da defesa e rearticulação 'do vernáculo'. Um tipo de desenvolvimento e intervenção alinhado com as diretrizes de agências das Nações Unidas como PNUMA ou, se não alinhado a elas, pelo menos muito coerente com os postulados que elas defendiam nesse momento

[...] esta tecnología propia de América Latina debe ser una tecnología adecuada a nuestras capacidades y necesidades y por esto entiendo aquella que cumpla con los siguientes lineamientos del Ecodesarrollo: 1) que respete los ecosistemas naturales alimentándolos y regenerándolos, adaptándose a su equilibrio natural; 2) que respete los patrones SocioCulturales; 3) que sea de pequeña ó gran escala; 4) lo suficientemente flexible para poderse implementar en etapas; 5) tendiente a la emancipación de tecnologías extranjeras; 6) que fomente la distribución del ingreso, la riqueza y el poder; 7) que incremente la productividad del trabajo; 8) que fomente la articulación de la economía; tanto de los sectores productivos como de las áreas geográficas nacionales (Rivera, 1980b, p. 2 e 3).

Dessa forma, bem na concepção do designer como erudito -no qual é possível se aderir a qualquer corrente-, como na participação dele na formulação de políticas nacionais sobre tecnologia e na cartografia do popular e o artesanal, estavam se jogando os caminhos que permitiriam superar aquele diagnóstico feito em torno dos males da dependência cultural. Essas podem ser as grandes coincidências. Porém profundas diferenças são mostradas na abordagem. Uma coisa é pretender 'modernizar' os processos vernáculos; uma outra é se inscrever neles como parte do processo. Coincidências no diagnóstico e na definição do inimigo. Profundas diferenças no desafio de compreender uma postura para resolvê-lo. 
4.

A partir das denúncias sobre a realidade latino-americana e passando pelas possiblidades para o bem-estar, os documentos refletiam sobre o papel da tecnologia como caminho para conquistá-lo. Ainda um pouco mais precisa do que as menções anteriores, a ligação bem-estar e tecnologia seguiu sendo abstrata.

A tarefa do design aparecia no panorama como substituto do que era compreendido como tecnologia. É o grande chamado que o design tem na América Latina. Assim, se a fórmula mais geral defendia que a tecnologia era o caminho possível para conquistar o desenvolvimento industrial, econômico e, finalmente, a autonomia cultual, o design se convertia no elemento que resolveria toda a sequência. Mas, nos imaginários dos autores, o design vai avançar mais um pouco nessa conquista. Colocando o ser humano no centro do problema -sobretudo os menos favorecidos-, todas as necessidades sociais dos programas dos governos, as suas políticas e planos, adquiririam sentido com a intermediação do design. Tanto brasileiros, como colombianos e mexicanos compartilhavam essa perspectiva, a do design compreendido como o elo que ligava toda a cadeia de causalidades... como promessa para a conquista da autonomia.

Semelhante responsabilidade atribuída ao design feito na América Latina, para a América Latina, também não vai mostrar uma cadeia de argumentos em que se compreendia a rota dessa relação... será como um devaneio... como um responder 'ao chamado'.

Os autores desses textos compreendiam bem que o desenvolvimento tecnológico era o caminho claro para o desenvolvimento social e cultural das suas sociedades. É necessário lembrar como o discurso sobre tecnologia apropriada também percorria a generalidade das preocupações de intelectuais e profissionais desde os anos 1960 em todo o mundo, já nos anos 1970 convertidos em discursos multilaterais. De tal maneira, todo esforço era norteado nessa direção. Tudo parecia em realidade uma defesa latinoamericana do desenvolvimento tecnológico da América Latina. Esse era o caminho mais apropriado... mais adequado para a quebra da dependência cultural da região. Nesse esquema, o design, que precisava se fortalecer e justificar como campo novo, parece mais uma desculpa. Me parece que a ideia do cubano Iván Espín pode tocar o centro do problema 
[...] en conclusión, los países subdesarrollados se ven ante la única alternativa de desarrollar el diseño o ser dominados, colonizados a través del diseño extranjero, colonialista. 0 los países subdesarrollados diseñan u otros diseñarán por ellos y en contra de sus intereses (Espín, 1980a, p. 5).

No trecho acima, a palavra design poderia ser substituída por tecnologia e o sentido da tese se manteria. De fato, esse sentido, quase que igualmente articulado foi escrito várias vezes para defender o papel da tecnologia apropriada ou criada em contexto local. Além disso, aqui, usando-a como substituto, a eficiência de todo o postulado vai repousar no esoterismo do design... aquele novíssimo campo que precisava se justificar no quadro central do escritório do Partido Comunista cubano, aonde Espín falava no ouvido. Se Che Guevara relacionava tecnologia própria com libertação e Espín conceituava o design como tecnologia, seguramente Che compraria o projeto de profissionalização desse tesouro que Espín lhe oferecia. ${ }^{30}$

\section{Design nas circunstâncias}

1.

Relembremos que a grande série que tento presentar nessa parte, pretende recolher nos textos, as generalidades da reivindicação cultural por meio de um vívido nacionalismo. A reivindicação de uma essência presente no vasto território que se apresentava e misturava com os lugares comuns de um potente latino americanismo. Um latino americanismo que por sua vez dava ferramentas para a compreensão do subdesenvolvimento regional por causa da exploração dos países do "Primeiro Mundo", principalmente, para a época, dos Estados Unidos. A materialização de um maniqueísmo.

Nesse marco, é relativamente explicável que os autores dos textos, dada a percebida ansiedade por ligar semelhante abstração com as implicações da cotidianidade, transitassem tanto na cimeira do que é a cultura latino-americana, as suas problemáticas e a necessidade de fortalecê-la para conquistar a autonomia, quanto no

\footnotetext{
${ }^{30}$ É claro que com esse silogismo estou desenhando uma figura retórica fictícia. 0 assunto não aconteceu dessa forma. Por exemplo, para a época em que Espín defende tal postulado, Che já tinha morrido. A minha figura pretende em realidade ligar três personagens num tecido. Como disse, Iván Espín (1) era irmão de Vilma Espín (2). Eles eram muito próximos conforme consegui determinar, ela sendo parte do bureau do Partido Comunista em Havana. Na sua parte Che Guevara (3) foi o promotor do Ministerio de Industria Ligera, onde materializou várias teses que tinha respeito da técnica, a industrialização e o desenvolvimento. Em 1964, Che contatou à designer cubana Clara Porset -que morava no México- com o propósito de implementar um programa de design na ilha. 0 tecido vai tomando forma.
} 
terreno do adestramento da sua própria cotidianidade com o exercício do design. Mas, caminhando o tempo todo nesse tipo de bipolaridade, é muito complicado sequer perceber o vínculo que liga as experiências de cada um com o design e a reivindicação das ilusões dessa terra que precisa se libertar. É difícil mesmo encontrar um argumento. ${ }^{31}$

Dai que fosse mais ou menos automático expor ideias no tom do manifesto, ou reflexando-o em forma de receita, que não é outra coisa que o estabelecimento de passos a serem seguidos para a conquista da abstração. Em um emotivo texto, Anamaria de Morais expressa um pouco esse tom de manifesto com que se transita entre as cimeiras dos ideais e as planícies da experiência

[...] assim, os desenhistas industriais estão do mesmo lado dos que vêem na industrialização a forma de romper as malhas do subdesenvolvimento e de melhorar a qualidade de vida das populações marginalizadas (Morais, 1980a, p. 2).

Não sei como, mas as qualidades que os autores desses textos vêm no design, estão alinhadas com as possibilidades de resolução dos problemas que afligem aquele território imaginado, chamado de América Latina. Porém são postulados que coincidentemente são vertebrais das críticas econômicas da CEPAL desde os anos 1940 e base de preocupações ideológicas durante algo mais do que 200 anos na região. ${ }^{32}$

\section{2.}

Uma das características que se reproduz permanentemente na documentação tem relação direta com a resolução das situações conforme a sua natureza e as possibilidades de intervir nas suas próprias circunstâncias. Uma clara dimensão que vê na prática da alienação um grande inimigo. Existe um evidente afã por fugir dessa alienação que está relacionada com a dependência cultural, no que parece realmente prático redigir

\footnotetext{
31 Talvez redunde mencionar que a metáfora de cumes, planícies e serranias que estou usando aqui não é minha, é de Marx.

${ }^{32}$ Além de como isso se deu em cada parte do enorme território, uma generalidade tinha encontrado: desde o século 19 uma linha de intelectuais latino-americanos tinham estado preocupados com o que Cancelli (2003) chama de miséria e pobreza. Na sua parte, logo depois dos anos 1920, o debate sobre a industrialização entrou na cena académica regional, se convertendo em prioridade para uma outra linha de argumentos desde esse momento. Um dois mais influentes teóricos do assunto foi o argentino Raúl Prebisch. De certa forma, as narrativas dos autores dos textos de Bogotá em 1980, recriam permanentemente uma e outra coisa, em um nível de inconsciência que -como já disse algumas vezes- lhe outorgam sentido de legitimidade ao processo.
} 
tratados ou listados de operações a serem feitas, com a ilusão de que os ideais maiores se concretizem.

Essa tácita denúncia de alienação -de seguir padrões e soluções estrangeiros para solucionar os problemas locais- reivindicara tanto campos de desempenho, quanto problemáticas sociais a serem resolvidas, assim como prontuários daquilo que deve ser praticado dentro do ethos circunstancial do design. Um assunto sensível e coerente com as situações latino-americanas, parecido com a reivindicação técnica promovida por Vicente Sánchez dentro do PNUMA, de Oscar Varsavsky nas suas críticas ao subdesenvolvimento científico, do papel da universidade latino-americana em Osvaldo Sunkel, do próprio Camilo Torres com as suas ideias sobre as técnicas e a qualidade de vida dos mais necessitados ou até do próprio levantamento político de Che Guevara, quando relaciona técnica com dependência. ${ }^{33}$

0 local, respondendo às carências locais, conceituadas pelos atores que as padecem e configuradas nas condições em que aquela sociedade as apresenta. Aí, tanto a qualidade de vida, quanto o desenvolvimento de tecnologia própria, unidos como baseamento da autonomia.

O tom de manifesto desses documentos entregues em Bogotá, pode evidenciar uma apaixonada e pouco racionalizada crítica sobre a realidade. Uma crítica que claramente era a reflexão da experiência de um grupo de latino-americanos, realmente cautelosos com os históricos problemas da dependência dos nossos países com a Europa e os Estados Unidos. Ao ser a reflexão da experiência, e ao se repetir nos mais diversos cantos da região com vários níveis de coincidência em pessoas que não se conheciam, essa crítica deixa entrever a sua legitimidade como uma forma regional de pensamento, embasada em sentidos comuns que circulavam na região desde várias décadas atrás. Uma dessas formas foi a denúncia de uma certa alienação que, no discurso desses autores, se evidenciava na briga contra a intervenção cultural externa, por meio da defesa de posturas reivindicatórias como o circunstancialismo... detectar, conceituar e resolver na própria situação, em meio das possibilidades que oferecem as circunstâncias. Uma perspectiva metodológica... uma postura política.

\footnotetext{
33 Já tratei o texto de Sánchez. Também mencionei algumas ideias de Varsavsky e de Camilo Torres. De Sunkel me refiro a dois dos seus textos dentro da CEPAL (1970; 1995) e de Che, aquele discurso de encerramento do congresso da UIA (Union Internationale des Architectes) celebrado em Havana em 1963 (Guevara, 1970).
} 
3.

À necessidade de fugir da alienação, concentrados nas exigências locais que expressavam as diversas problemáticas sociais, os autores somavam uma evidente reivindicação essencial, à qual já fiz referência em vários momentos do texto. Essa reinvindicação se construiu no esforço de inscrever o design na linha de pensamento crítico que defendia o desenvolvimento tecnológico e que vinha se fortalecendo nos discursos multilaterais, tanto como caminho para o melhoramento da qualidade de vida da população como relativa garantia da industrialização.

Determinando as carências por meio de uma processo no qual os afetados pudessem participar e cuja orientação fosse dada por profissionais que estivessem familiarizados com essas situações, se avançava no caminho da independência tecnológica e cultural. A resolução dessas carências convertia-se na oportunidade de amortecer os impactos provindos dos processos de industrialização... de novo, a cadeia causal parecia se fechar com o design como elo

[...] como necessidades do usuário devem ser entendidas não somente aquelas do individuo, mas também as do grupo social caracterizado pelos aspectos sócio-econômicos-culturais da região geográfica de atuação do produto. Como possibilidade de produção devem ser entendidas a adequação às limitações de matérias-primas, características do parque industrial, disponibilidade de mão-de-obra, dentro do contexto geoeconômico (APDINS-RJ; APDINS-PE; ABDI, 1979b, p. 5).

Esse propósito seria possível a partir do rompimento com uma formação acadêmica alienada para os designers... uma formação que estava focada em reproduzir na realidade latino-americana, os procedimentos para resolução de problemas usados na Europa e nos Estados Unidos. Com poucas exceções, os documentos entregues em Bogotá tratavam desse tema, colocando-o em vários momentos como eixo reflexivo e se convertendo em uma das mais contundentes coincidências no discurso das distintas delegações

[...] em nossa opinião seria indispensável que um currículo mínimo desenho industrial estivesse em sintonia com as características e as necessidades contextuais básicas brasileiras. Por esta razão, discordamos das orientações pedagógicas que tendem encaminhar o aluno apenas para as formas mais complexas da produção industrial, próprias dos países desenvolvidos (APDINS/RJ, 1978, p. 9). 
As preocupações com a ameaça de uma rompante alienação no exercício do design, denunciavam a tendência em seguir padrões importados na realidade do contexto. A solução defendida era a de que a tecnologia devia nascer no contexto para satisfazer as carências dos mais necessitados. 0 contrário garantiria a dependência. Uma tecnologia própria permitiria a melhora da qualidade de vida das pessoas enquanto impulsionaria no seu próprio ritmo o processo de industrialização. As preocupações quanto àquela alienação e àquela criação descontextualizada justificavam as reinvindicações por uma formação sensível dos designers latino-americanos. Uma sensibilidade, embasada numa complexa base de elementos -próxima da erudição- que permitisse que os designers formados reconhecessem criticamente a sua realidade para então poder mudá-la.

\section{Essencialmente distintos}

1.

Uma outra forma de fugir dessa alienação emergia dos enunciados. Timidamente no coração da denúncia sobre as circunstâncias morava uma inclinação para a exploração da ideia de identidade nacional. Uma estratégia essencialista como mecanismo para superar a alienação e a descontextualização. Uma superação como promessa da aproximação do interesse industrialista com o bem-estar daqueles indivíduos necessitados - parte das camadas populares- que se convertiam em sinônimo da identidade nacional. Um primeiro passo: resolver as carências dos despossuídos era possibilitar a salvaguarda daquilo que era realmente nacional... a população e as suas costumes.

Aquela salvaguarda era toda uma recriação populista, que possivelmente estava chagando na ciência coletiva dos intelectuais da época, procedente das práticas políticas mais ou menos comuns em vários países da Latino América desde os anos 1930 e 1940. Ainda geral era uma entrada na compreensão da essência, daquilo que só era nosso, como mecanismo para alcançar a resolução dos nossos problemas conforme nossas circunstâncias por meio de um olhar vertical e exótico dos outros.

Tanto a resolução das carências dessas camadas populares, quanto a sua criatividade eram compreendidas como motor para a conquista do bem-estar. Uma e outra coisa, inscritas nos postulados defendidos por Vicente Sánchez do PNUMA sobre tecnologia apropriada, que mencionei no capítulo anterior. 
Essa perspectiva ainda não podia se desfazer da pressão pelo desenvolvimento econômico da população: aquelas premissas que pretendiam associar a qualidade de vida e bem-estar. Porém houve um outro matiz na compreensão dessa questão. Um olhar que ainda estivesse relativamente interessado nos problemas da industrialização, parecia compreender esse mecanismo essencial encontrado na criação artesanal e/ou popular como um fim em si mesmo

[...] todo o design brasileiro deveria fazer uma autocrítica: a primeira, de origem, pois ele conseguiu se implantar mesmo não levando em consideração a produção artesanal do país, o que é um absurdo dentro de um país como o Brasil, que tem uma belíssima produção artesanal. Em nenhum momento o desenho industrial procurou pesquisar suas fontes, suas origens, todo um trabalho tradicional feito em cima da madeira, do couro, do barro (Ventura, 1977, p. 1).

Parece claro que a ideia de Ventura fosse a saída da alienação, sugerindo que aqueles que reproduziam acriticamente as diretrizes estrangeiras estavam atropelando a realidade local. Um cenário local com sua própria história, a qual é preciso aprender. Um cenário que pode significar tanto o sentido, quanto o significado do design nacional

[...] finalmente Aloísio Magalhães, numa tentativa mais abrangente, colocou sua intervenção a serviço da valorização de nossas raízes culturais. Para ele será do processamento das manifestações autóctones da cultura popular que poderão surgir os indicadores para um design tipicamente brasileiro. Aloísio, numa conferência extremamente estimulante, arrancou a platéia de seu habitat urbano e transportou-a para além da costa atlântica, para o interior do Brasil, colocando-a em contato com alguns traços culturais das regiões mais pobres (Escorel, 1976, p. 4).

\section{2.}

A ideia de que o verdadeiramente nacional, o realmente latino-americano, estava ligado às populações históricas do território, também foi uma ênfase dessa abordagem. Desde as mais recentes, passando pelos tempos de colônia e as suas contribuições culturais, até chegar nas comunidades pré-colombianas... considerados verdadeiros e originais habitantes do território. Esse tipo de ideias estavam presentes em várias passagens dos textos das delegações da Guatemala, Costa Rica, México e Colômbia

[...] es posible afirmar que la tecnología y equipo de los pueblos precolombinos se encontraba a la llegada de los conquistadores en un adecuado punto de eficácia (Gámez et al., 1980, p. 3).

[...] ¿Qué pasó con las Culturas Precolombinas que maravillaron al mundo entero, como La Inca, La Maya, La Olmeca, La Azteca?; actualmente las tenemos confinadas a recintos museográficos y nos 
hemos dedicado a importar y copiar tecnología extranjera desde el descubrimiento de América hasta nuestros días (Rivera, 1980b, p. 2).

Para esse argumento estava clara a possibilidade de fugir do voluntarismo, a descontextualização e a alienação por meio da reivindicação daquilo que foi feito e praticado pelos habitantes da América Latina antes da chegada dos europeus no século 15... antes da chegada dos intrusos. Não escondendo-os, nem passivamente contemplando-os, mais sim protegendo-os na sua tradução moderna tanto quanto na sua preservação, como forma de se valorizar o popular. Essa forma de ver os antigos habitantes parece não estar muito afastada da tendência do pensamento moderno que avalia 'o outro' de forma exótica, no melhor dos casos, como um canteira da qual se recolhe os elementos para o trabalho

[...] no desconocemos con lo anterior los hechos históricos que han influido en la conformación de nuestros pueblos. La conquista y su significado. La colonia y el Patrimonio Cultural que nos legó. La independencia y su indestructible lema de libertad. Después, la influencia Europea y mas recientemente la Norteamericana en aspectos económicos e industriales que han marcado avasalladoramente nuestros nuevos patrones de comportamiento. Pero por todo esto precisamente y por conocer que nuestro bagaje cultural es superior al que puedan pretender los llamados países desarrollados es necesario pensar un poco mas en lo colombino para poder hablar en breve plazo del Diseño Industrial Colombiano en vez, del Diseño Industrial en Colombia (Gámez et al., 1980, p. 1 e 2).

Defende-se claramente o pré-colombiano. Também existe espaço para reconhecer elementos deixados pela colônia mas sobretudo o valor do espírito libertário da independência. É aceita a influência europeia. 0 que não se digere -assim se compreenda- é o avassalador sobrepasso norte-americano e a sua intromissão na vida da região... é um espírito antiimperialista, antiyankee nesse caso, como aquele que da origem à ideia política denominada América Latina no século 19 (Quijada, 1998) e que Hobsbawm (2010) assinala como uma característica do nacionalismo latino-americano durante o século 20. Mais adiante contornarei. 


\section{Design e subdesenvolvimento}

[...] para Huntington, los desafios a la supremacia política económica de Occidente y los valores que caracterizan su identidad cultural definen una nueva situación internacional en la cual la opocisión entre "el Occidente y el resto" asume el papel central. Para él, siete civilizaciones componen el "resto": japonesa, confuciana, islámica, eslava, ortodoxa, hindu, africana y latinoamericana (Ayerbe, 2012, p. 26). ${ }^{34}$

A terceira série da documentação é o grupo de ideias que pretende colocar o cenário econômico e social como justificativa para o fortalecimento do design na América Latina. Embora essa justificativa pareça a mais explícita e, até mesmo, compreensível, também fica claro que os autores desses textos a usaram para se inscrever em um debate que atravessa a história da região: o debate sobre a autonomia.

Nos enunciados aparecem frequentes relações das mesmas categorias analíticas, marcando essa grande série -design e subdesenvolvimento- como uma das mais homogêneas na apresentação dos textos. Divididos em dois grandes blocos, essas ideias conseguem desenhar um sistema de causas e consequências que parecem pretender o estabelecimento de uma rota histórica que explica a existência do modelo de desenvolvimento implementado na região e os seus gravíssimos problemas.

É relativamente fácil perceber que a coletânea ou descreve o que entende como trajetória do modelo econômico ou denúncia a dependência da América Latina em relação ao "Primeiro Mundo", de onde tanto o nacionalismo como o clamor pela autonomia retoma a sua força. Claro, esse nacionalismo se alimenta permanentemente da crítica econômica que tão contundentemente circula na América Latina durante a segunda metade do século 20. Mas também das mais variadas rotas de reivindicação democrática e cultural que rondam os nossos países nesses anos: desde a Teologia da Libertação, passando pela crítica comunista, até chegar na chamada Filosofia da Libertação promovida desde a Argentina nos finais dos anos 1960.

\footnotetext{
${ }^{34}$ A citação original é: "japonesa, confuciana, islámica, latinoamericana, eslava, ortodoxa, hindu y africana”. Troco a ordem apresentada por Ayerbe, para colocar tensão sobre América Latina como realce dramático do meu argumento.
} 
Essas frentes, assim como algumas outras, se convertem em vasos comunicantes de ideias de reivindicação daquilo compreendido como 'o nosso', no caldeado cenário da Guerra Fria e as tumultuosas relações com os Estados Unidos.

\section{Matrizes da desigualdade}

1.

0 primeiro bloco de postulados cobre um pouco mais do que a quarta parte das ideias relacionadas com a crítica econômica e social, como base para apresentar as trajetórias do modelo e foram expostas principalmente pelas delegações do México, Argentina, Cuba, Brasil e Colômbia. Nessas trajetórias vai ser frequente a alusão da linha histórica que pode explicar a dinâmica da política econômica e social da América Latina nos anos 1970, assim como as trajetórias convertidas na causa dos graves engendramentos que explicam a dependência latino-americana dos países desenvolvidos.

Os documentos das delegações argentina, brasileira e mexicana foram os que desenharam o trajeto do processo de implementação do modelo econômico com maior claridade. Sabemos que junto com o Chile -apesar dele iniciar num nível menos complexo-, são esses três países os que conseguem se adiantar nos processos de industrialização na região, com referencias na última década do século 19.35

Além dessa coincidência, é interessante notar a equivalência em torno da crítica dos problemas referentes ao modelo ISI -Industrialização para Substituição de Importações-, coincidindo com as críticas que a CEPAL estabeleceu como problemas do modelo. Lembro que a ISI, respondia à necessidade de industrializar a região, como caminho para quebrar a dependência com a Metrópole

[...] [na Argentina] el crecimiento vertiginoso de la industria productora de bienes de consumo, ha de detenerse en los anos 50, debido en parte a la carencia de industrias de base, la dependencia del sector respecto a materias primas y tecnologia. La industria pesada [...] y de materias primas [...] comenzará a desarrollarse, debido a las altas inversiones requeridas, con el concurso del capital extranjero, lo que trae aparejada

\footnotetext{
35 Luis F. Ayerbe apresenta um quadro feito por Cardoso e Brignoli, no qual é traçado o início do processo de substituição de importações na região. É interessante notar que a Argentina, o Brasil e o México iniciam no nível avançado em 1890, enquanto o Chile no nível intermediário -os níveis estão relacionados com a participação de determinados setores na economia e a porcentagem do seu impacto no PIB-. A Colômbia secunda o bloco, iniciando em 1900. Uruguai em 1920, para registar em 1940 o início na Venezuela, Peru, Bolívia, Paraguai, R. Dominicana, Haiti, Panamá, Guatemala, Honduras, El Salvador, Nicarágua e Costa Rica (Ayerbe, 2012, p. 82).
} 
la importación de modelos y desarrollos foráneos (Colmenero \& Nápoli, 1980, p. 1 e 2).

É interessante ver a cadeia causal na documentação. Ficar no primeiro nível ISI -de manufaturas- tinha engendrado uma relação direta entre as mercadorias, a tecnologia e os bens de capital com a dependência econômica e cultural 'dos nossos povos'. Também -enorme paradoxo- tinha produzido uma relação de paternalismo que ligava o capital estrangeiro e os seus apetites, com a importação de modelos que não tem ligações com as condições do cenário cultural: toda uma alienação.

Assim, à promessa da autonomia concentrada na estratégia de substituição de importações dos anos 1940, seguiu a quebra da ilusão no início dos anos 1960. A CEPAL e outros críticos econômicos analisaram e denunciaram várias causas durante os anos 1960 e 1970.

Os autores dos textos entregues no congresso da ALADI em Bogotá, realçaram a compra de tecnologia estrangeira como grave engendramento da estratégia. Essa era precisamente uma das causas tratadas pelos especialistas. Nessa prática se adquiriam bens obsoletos que garantiam a dependência com quem o produz e se reproduziam modelos estrangeiros que não correspondiam às condições locais. Uma linha causal que perpetuava a dependência do centro

[...] el modelo de desarrollo adoptado por el gobierno mexicano en la década de los 50s, se basó en la importación de los bienes de capital [...] la tecnología, la maquinaria, el diseño, etc [...] 30 años después los resultados no son tan halagadores en cuanto a parámetros de producción industrial, agrícola, deuda externa e inflación [...] la tecnología a la venta de los países industrializados [es] obsoleta y anticuada [...] además de la dependencia que se genera tecnológicamente hablando, se genera una dependencia económica [...] y a la larga esto desemboca en una dependencia cultural (Rivera, 1980b, p. 1).

2.

As delegações presentes em Bogotá traçaram alguns elementos que consideravam causais dos problemas dessa trajetória. Presentes na maioria dos documentos e muito claramente tratados pelo cubano Iván Espin, aqueles esforços marcavam uma relação direta entre a desigualdade na troca e a dependência, com a matriz que as produzia 
[...] la característica fundamental de esta dependencia [econômica imperialista] puede enunciarse como la del intercambio desigual: Estados Unidos compraba a Cuba su mono producto: el azúcar, a muy bajo precio vendiéndoles tecnologías, equipos y productos industriales a muy altos precios. Cuba carecía de una sólida tradición artesanal, el desarrollo de una industria nacional era desestimulado, y el mercado estaba inundado de productos libres de aranceles que preconizaban el "American Way of Life" (Espín, 1980a, p. 1).

Esse argumento aparece como uma recriação das preocupações que tinham-se materializado na crítica cepalina. Quem olhar na figura de Raúl Prebisch, encontra esse tipo de enunciados nas suas preocupações. ${ }^{36}$ Claramente ele não era o único. Love (2011) reconhece a presença do romeno Manoilescu nos argumentos dos pioneiros que se aventuraram em empreendimentos industriais em São Paulo nos anos 1920. Para eles, como para o equatoriano Victor Estrada (em 1922), esse era o papel das economias agrárias, estabelecendo um paternalismo determinante entre o Centro -nesse momento a Grã Bretanha- e a Periferia. As expressões entusiasmadas de Manoilescu mostravam o grande golem do sistema estabelecido por Londres... era um sistema que impunha que uns trabalhassem para outros em estado de servilismo. ${ }^{37}$

Desse ponto de vista -considerando o fracasso da ISI nas décadas posteriores (1960 e 1970)- era possível pensar que os problemas generais do subdesenvolvimento tivessem relação com o arrivismo das elites latino-americanos no poder. Algumas ideias de Marx a respeito da ineficiência e da concentração de renda gerada por certo tipo asiático de exploração produtiva, expunha uma grande preocupação com o acúmulo de riquezas e assinalava nessa prática, já nos anos 1950, o âmago do subdesenvolvimento. Não digo que a ciência das teses de Marx determinassem o olhar dos nossos latinoamericanos em Bogotá. Na verdade, dados os argumentos desses documentos que estou analisando, assim como algumas percepções que tinha construído nas minhas conversas com vários desses autores, vou apostando na ideia de que eles não tenham estudado Marx no estado puro -no capítulo seguinte aprofundarei o assunto-. Porém, mesmo que

\footnotetext{
36 Prebisch foi um economista argentino a quem se atribui a conceitualização "Centro - Periferia", para explicar as relações entre, nesse momento, a Inglaterra e a Argentina. 0 desenvolvimento teórico de Prebisch data de 1944 na Universidad de Buenos Aires (Love, 2011). Entre muitos cargos, ele foi o primeiro diretor da CEPAL.

37 "Manoilescu asseverou que o trabalhador agrícola e que as nações dedicadas à agricultura "são pobres e continuarão pobres" enquanto não se industrializarem. Assim a divisão internacional do trabalho não passava, basicamente, de um logro: a clássica teoria do comércio internacional "justificava" a exploração de um povo por outro" (Love, 2011, p. 166).
} 
não tivessem estudado as suas obras, isso não significa que as suas teses -ou imagens delas- não tenham chegado até eles, sobretudo nas condições do cenário em que viviam. Sabemos que durante essas décadas as releituras do marxismo e as suas reelaborações rondavam a América Latina, convertendo várias delas em parte dos lugares comuns de determinados segmentos sociais. A sua circulação é difícil de negar

[...] existe evidencia amplia que nos permite con alto grado de confiabilidad, decir que el atraso tecnológico y la casi total inexistencia de diseño de productos son el resultado de una política tecnológica explícita, en que se han protegido los intereses a corto plazo de los grupos en el poder [...] "copyright rights" patentes, uso de marca, royalties, derechos de autor, y otros son los mecanismos con los que en los tiempos modernos se protegen e incrementan las ganancias del grupo en el poder [...] son sólo un botón que para muestra basta de la inmensa dependencia tecnológica Nacional (Domínguez, et al., 1976(?), p. 6 o realce é do documento original).

\section{3.}

Para os mexicanos que escreveram o documento do trecho anterior, a causa da dependência está diretamente relacionada com o arrivismo da elite mexicana. Dada a relativa crise da estratégia ISI, várias linhas críticas, entre as quais as análises contidas na chamada Teoria da Dependência no interior da CEPAL, assinalaram na atitude arrivista das elites boa parte do problema estrutural que impede o desenvolvimento dos países da região. Para o debate que levanta esse tipo de teses, as burguesias nacionais não só não orientavam o processo de desenvolvimento, mas não eram inocentes frente à perpetuação do subdesenvolvimento regional.

Certas linhas críticas defendiam que era necessário fazer alguns ajustes a respeito do modelo. Ajustes que promoveriam o dinamismo tecnológico e a satisfação das carências das pessoas, principalmente os chamados de 'marginais'. De viés conservador, essa linha era defendida por aqueles que achavam que América Latina estava no processo correto para conquistar o desenvolvimento; era só superar os obstáculos. Uma outra linha questionava o centro desse postulado. Elaborada sobre a ideia de que América Latina é capitalista desde o século 16, mostrava a região em uma posição e não em uma fase de desenvolvimento. Os seus adeptos defendiam que a principal causa era a elite arrivista e o único caminho era a revolução. Retomarei esses pontos no próximo capítulo.

Alguns enunciados na documentação de Bogotá deixam perceber a recriação desse binarismo. Uns textos aderidos à ideia de apoiar o processo em marcha, outros 
denunciando o arrivismo da elite e sugerindo o seu apoio para a mudança radical. Se é correta a minha leitura, pode ser mais outra das notórias diferenças de enfoque entre os fundadores da ALADI, explicando a clara existência de pelo menos duas ALADIs no início mesmo da associação. ${ }^{38}$

\section{Propósitos falseados}

1.

Desde uma forte denúncia sobre as prioridades das políticas industriais nacionais, passando pela forma como as classes médias conformavam a sua cotidianidade, esses enunciados também parecem estar ligando o subdesenvolvimento com a dependência cultural -enorme mal e grande inimigo- e ela com o arrivismo da elite. E parecem ir em busca dessas ligações com o propósito de conformar uma denúncia da latente distorção nos propósitos do projeto de modernização da região

[...] a política econômica do governo brasileiro [...] acentuou esta dupla dependência, na medida que facilitou [...] a importação de capital e tecnologia e consolidou a implantação, no país, de um parque industrial [...] voltado principalmente para a produção de bens de consumo [...] destinados à exportação ou a um mercado interno concentrado geograficamente [...] constituído basicamente pela burguesia e alta classe media, favorecidos pela mesma política econômica, que comprimindo o poder aquisitivo dos assalariados proporcionou uma crescente concentração de renda nas mãos desta minoria privilegiada (Nascimento, 1979, p. 2).

Era necessário visualizar um caminho na encruzilhada que marcava a distorção do propósito para o projeto moderno na região. Era clara a presença de elementos alienígenas na realidade da América Latina, assim como a concentração da riqueza. De igual maneira estava denunciada a existência de uma linha causal arrivismo/elitismosubdesenvolvimento-dependência... na conjuntura do primeiro e o segundo era evidente a deformação do propósito do processo, assim como a incoerência histórica que significava

\footnotetext{
38 É uma figura retórica. Procurando ser sensível com a documentação, esses dois matizes aparecem em torno dessa perspectiva -crítica do desenvolvimento-. Contudo é claro que existem mais outras perspectivas que pretendem conceitualizar o sentido de uma associação como ALADI. 0 trecho de Roberto Napoli -delegado argentino em Bogotá- que citei em páginas anteriores, oferece um claro exemplo disso.
} 
[...] portanto o país [Brasil] produz e consome o pior e ainda pagando altíssimos preços. As necessidades reais de consumo da maioria da população não são sequer consideradas e a produção industrial volta-se pura e simplesmente para os segmentos onde, usando a linguagem dos mercadólogos, identificam-se "oportunidades de mercado" (Nascimento, 1979, p. 4).

Como substrato, essa distorção de propósitos foi denunciada na mais variada gama de menções. As delegações problematizavam o desajuste do processo de industrialização, assinalando que as produções não estavam voltadas para a satisfação das necessidades da população.

Dois níveis poderiam marcar esse tom. De um lado, as ideias que propunham a questão de forma abstrata, com menções generalizadas ou apontando as consequências de adotar soluções pertencentes a outros contextos. ${ }^{39}$ No coração daquele nível de enunciados respirava a reivindicação circunstancialista do contexto, que seguramente era estimulada pelos diferentes diagnósticos críticos que circulavam pela região desde os anos 1940.

Precisamente para esse ponto vai apontar o segundo nível dentro das menções sobre a distorção dos propósitos da modernização. As preocupações dos autores de vários documentos da coletânea giram claramente em torno das condições habitacionais, o acesso à saúde, a educação, o transporte, em geral à qualidade de vida, tanto das camadas populacionais que estavam se assentando nas cidades por causa das migrações que promoviam a urbanização, quanto daqueles outros que moravam no campo. No final, como mencionei em páginas anteriores, a grande maioria dos autores desses documentos consideravam que a essência 'do nacional', morava no popular e no camponês. Enquanto essas carências não se resolvessem, o processo de modernização continuaria sendo uma fantasia disposta para o benefício de poucos.

2.

Dentro da necessidade por compreender as causas, vários desses textos também apresentam preocupações com os pecados que comete o sistema ao importar tecnologia.

\footnotetext{
39 “a produção industrial não está voltada para as necessidades básicas da maioria da população [...] Os produtos industriais, na maioria dos casos, desde que foram projetados para uma outra realidade, não atendem as nossas necessidades materiais e culturais, tornando-se um dos fatores básicos no processo de desequilíbrio ecológico, de desperdício de recursos naturais e de aniquilamento dos nossos valores culturais" (Nascimento, 1979, p. 2).
} 
Uma explícita inquietude dos autores com os problemas da migração interna e a escassa absorção daqueles migrantes nos processos de industrialização, marcam parte desse tipo de enunciados. São inquietações que pretendiam ligar em abstrato o modelo de desenvolvimento com aqueles fenómenos. No México, por exemplo, denunciando a generalidade econômica que impacta o social "dicho modelo de "desarrollo" ha generado otros problemas [...] como [...] 5) migración del campo a la ciudad" (Rivera, 1980b, p. 3), no Brasil, assinalando as suas consequências no desemprego e a miséria

[...] a tecnología utilizada, cada vez mais sofisticada, tende a liberar cada vez mais mão-de-obra, em uma região onde o desemprego da população ativa atinge índices altíssimos (Nascimento, 1979, p. 2).

É interessante notar como essas preocupações também se relacionam com a crítica dos anos 1960 ao modelo ISI. Bem provinda da CEPAL quando observou a tendência de pouca absorção que marcou a industrialização já no final dos anos 1950, como nas anotações que debate a crítica comunista na região sobre o mesmo fenômeno. Da mesma forma, é interessante ver como esses pecados se ligam com o processo de importação de tecnologia para a industrialização desde aquelas observações da CEPAL, lá nos finais da década de 1950. Segundo Love, ao diagnosticar a queda do ritmo de industrialização na região, Raúl Prebisch assinalou em 1963 um dos impedimentos ao desenvolvimento: a tecnologia importada

[...] em 1956, a Cepal expressara suas primeiras dúvidas sobre se a indústria, na região do mundo com maior crescimento populacional, podia absorver o excedente de mão de obra da agricultura [...] problema, em parte, era a tecnologia poupadora de trabalho que a Periferia importara do Centro [...] na América Latina, no século XX, ao contrário da Europa do século XIX, a tecnologia era exógena à economia regional e destinava-se especificamente às necessidades dos países desenvolvidos (Love, 2011, p. 209).

Note-se como o sentido da primeira parte desse trecho é praticamente igual ao trecho brasileiro que mencionei antes. A referência das preocupações de Raúl Prebisch data de 1956; o documento de Nascimento de 1979. Uma coincidência que por enquanto deixarei simplesmente anotada.

3.

Mais um matiz será tratado no esforço por aterrissar essa relação entre tecnologia e dependência. A partir de uma perspectiva ainda um pouco mais geral era pretendido 
defender a ideia de que a entrada de tecnologia na realidade do desenvolvimento local enfraquecia a economia nacional. As causas: o estabelecimento de grandes vínculos com as multinacionais, as suas diretrizes e o seu know-how. Ainda que os argumentos se apresentassem de forma mais sossegada do que em outros momentos, não diria que sejam ilações causais expressas. ${ }^{40}$

Para essa linha de argumentos tanto multinacionais quanto know-how e financiamento andavam de mãos dadas com o problema da descontextualização tecnológica. Há uns parágrafos mencionei como esses autores viam como problema o fato de que a tecnologia não estivesse sendo empregada para solucionar as necessidades da população. Um pouco mais atrás também tratei as denúncias de problemas que trazia a imposição tecnológica, segundo as conceptualizações de Vicente Sánchez.

Estava claro que transferir maquinaria, produtos, sistemas visuais, etc., era introduzir formas de resolver, de viver e de pensar... era permitir a penetração cultural. Ao defender e reivindicar a criação local para a resolução do local, os autores dificilmente negociariam com a ideia de deixar entrar um pacote de paradigmas que ditassem o que e o como deveria se resolver uma carência

[...] a importação de tecnologia [...] torna a nossa economia cada vez mais débil e dependente [...] tornando-se um dos fatores básicos no processo de desequilíbrio ecológico, de desperdício de recursos naturais e de aniquilamento dos nossos valores culturais (Nascimento, 1979, p. 2).

[...] hemos creído que la tecnología apropiada puede ser una fuente muy adecuada para ser analizada, adaptada y probada como respuesta más funcional y económica a los problemas mencionados (Durán, 1980, p. 1).

4.

Uma outra dimensão caracterizava o modelo dos países da região nos enunciados da coletânea. Ela envolve os grandes obstáculos para o desenvolvimento, e vai se dar na conjunção entre a concentração da riqueza e os meios de produção numa mão e na outra, o conchavo estabelecido tanto pela satisfação dos interesses particulares das

\footnotetext{
40 "la solución a esta problemática [melhoramento das condições de vida da população], ha sido planeada utilizando tecnologías tradicionales [o contexto deixa entender que o autor realmente está falando de tecnologias importadas], las cuales, entre otros aspectos implican: mano de obra especializada, materiales prefabricados y créditos, componentes estos que han presentado en muchas oportunidades problemas de carácter no sólo técnico, sino también económico para el usuário" (Durán, 1980, p. 1).
} 
elites quanto pelo seu arrivismo... um eco das distorções do modelo que coloquei umas paginas atrás.

O seguinte trecho é uma metáfora tirada de um documento apresentado pela delegação brasileira em Bogotá. Provém de um texto que por sua vez reúne as

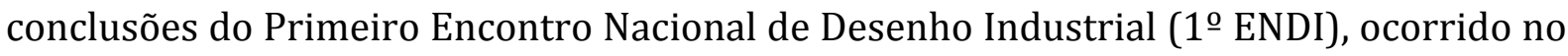
Rio de Janeiro em outubro de 1979 -treze meses antes da reunião em Bogotá-: "primeiro o bolo precisa crescer para depois ser distribuído" A distribuição vai ser concedida? Por quem? Quem se interessa por ela?" (APDINS-RJ; APDINS-PE; ABDI, 1979c, p. 2).

Quero me deter nesse trecho que me parece significar grandes sintomas. Por um lado, o seu contexto envolve uma pequena discussão sobre o propósito do desenvolvimento tecnológico e da qualidade de vida, aderindo à defesa do desenvolvimento tecnológico como base para a conquista do bem-estar da população. No documento original, umas doze ou treze frases acima, o texto chama a atenção na necessidade de incluir esse debate nos exercícios de definição da jurisdição do design, reconhecendo a existência desse interesse em cenários maiores e mais antigos.

Fóruns nacionais no Brasil, como nos outros países da América Latina, estavam tentando se alinhar com as preocupações e os desafios que trazia o grande projeto de modernização social. A metáfora apresentada no trecho brasileiro ilustra bem o sentido da redistribuição da riqueza. Pode ser importante relembrar que durante os anos 1960, para alguns intelectuais -principalmente da CEPAL- era necessário passar da ISI à estratégia de redistribuir para crescer (Bielschowsky, 1998).

Mas a figura retórica também pode estar denunciando por meio da sátira, um estado que não seria alcançado. Já não como um lamento impreciso, e sim como uma filiação no paradoxo que construiu o comunismo heterodoxo. Para essa linha crítica só era possível superar os graves problemas da região seguindo o exemplo de Cuba... mudando o sistema e trocando a elite do poder. 0 argumento, parece mais ou menos simples: não podia seguir se compreendendo a elite como um grupo que estava norteando a região para o capitalismo como promessa do bem-estar. Como mencionei, os heterodoxos defendiam a tese de que América Latina já era capitalista desde o século 15 , não em fase mas sim em posição de periferia 
[...] [o modelo] coloca a nível "consumista" um pequeno segmento da população, concentradora da renda, provoca o endividamento das camadas sociais médias e mantém em padrões de vida sub-humanos as populações periféricas (APDINS-RJ; APDINS-PE; ABDI, 1979a, p. 5).

Claro postulado causal que denuncia o arrivismo das elites como epicentro do subdesenvolvimento. Clara perspectiva crítica construída nas reflexões cepaliana e na crítica comunista de intelectuais como Andre Gunder Frank.

Esperar que o bolo crescesse era o mecanismo sínico para manter a viva esperança de que a região estava certa no difícil caminho para o bem-estar. Quem sabe, expressada no contexto do trecho em debate, essa ideia era uma sátira do que era defendido pelas elites latino-americanas sobre o desenvolvimento. Tudo isso também pode ser uma enorme sobre interpretação da minha parte. Em todo caso, o que encontro de valioso na metáfora brasileira, e que em realidade é o que quero mostrar nessas pressuposições, é uma referência à crítica latino-americana do desenvolvimento latino-americano. Conscientemente ou não, essa era uma forma de participar dessa grande preocupação deixada na mesa pelo desgaste do modelo de desenvolvimento dos anos 1950.

\section{Copia e royalties: dependência}

1.

Essas cadeias causais explicam o subdesenvolvimento na região. Ao estarem presentes como grandes pecados do modelo, promovem a mencionada distorção nos propósitos do processo como grande projeto social. Talvez por causa dessa preocupação os argumentos também transitem em torno do problema duplo da prática da cópia e o pagamento de royalties. Na perspectiva mais geral, ao se compreender como um atentado contra a autonomia técnica e cultural da América Latina; na crítica mais concreta, sendo uma ameaça contra o campo do design.

De diferentes documentos podem emergir dois tipos de críticas sobre a prática da cópia de produtos: o gasto de dinheiro com um ligeiro matiz norteado para o agravante de usar recursos que deveriam se inverter nas prioridades do desenvolvimento, e a cópia como garantia do fracasso da exportação 
[...] continúa en Guatemala un desarrollo industrial considerable. Dicha industria en lo que a fabricación de productos se refiere paga en regalías de Diseño cantidades fabulosas; y el comercio, ávido de nuevos productos, importa un gran porcentaje de los mismos [...] esta situación [irresponsabilidade do empresário ${ }^{41}$ ] se manifiesta a través de la importación de licencias o permisos de producción para fabricar objetos que más adelante comercializará. Dicha importación de diseños requiere el pago de regalías que en algunos casos alcanza cifras alarmantes (Arroyave et al., 1980, p. 1 e 4).

É relativamente claro que para esses guatemaltecos a existência de um profissional que projeta mercadorias dentro do país pode substituir esse gasto de recursos, destinando-os para as carências latentes da sociedade. Ou seja, seria possível alcançar a resolução de problemas reais nas condições em que se apresentam assim como justificar o valor e a importância social dessa nova disciplina no contexto.

Agora, essa relação cópia-gasto de dinheiro é acompanhada pelo grave paradoxo que engendrava no médio prazo

[...] um dos nossos maiores produtos de exportação é o calçado, que tem grande aceitação no mercado americano; pergunto: existe algum projeto de desenho industrial em relação ao calçado? Não, o desenho é imitado do italiano [...] o que se faz é copiar (Ventura, 1977, p. 2).

É importante mencionar que uma das estratégias que pretendia ajustar os problemas gerados pela ISI, foi o incentivo à industrialização por meio da promoção das exportações de bens terminados. De diferentes formas, esse projeto se estabeleceu nos países da região sem muita distinção. Em alguns deles sendo o motor que impulsiona a profissionalização acadêmica do design. Dessa postura que as preocupações pela exportação estiveram no centro do debate, sobre tudo ao se compreender que o sucesso daqueles produtos no exterior eram a garantia para fortalecer a industrialização e com ela toda a linha causal do desenvolvimento. Porém, sobre essa garantia estava a questão se nos mercados externos eram vendidos produtos latino-americanos que eram cópias de projetos de outros países. Já mencionei as sentenças de Juan Buenaventura -o funcionário de PROEXPO, na Colômbia- a respeito.

\footnotetext{
${ }^{41} \mathrm{~A}$ irresponsabilidade é minha forma de sintetizá-lo. 0 texto menciona, com tom de denúncia, que o empresário guatemalteco é ou cômodo, ou negligente, ou desleal.
} 
2.

Vários documentos afirmam que a falta de recursos para a inversão e o desenvolvimento tecnológico nacional é uma das causas que explicam que as empresas decidam copiar modelos estrangeiros e, no mais sofisticado dos casos, entrar no circuito de pagamento de patentes.

Pode ser importante relembrar, que os autores desses textos estavam interessados em justificar a importância da existência de uma profissão como o design, em uma realidade social como a latino-americana. Também pode ser útil mencionar de novo que a grande maioria deles -se não todos- chegaram ativos nesse trabalho justificativo, por causa da variada criação de argumentos para justificar a presença do design nos seus próprios países. Menciono de novo uma e outra coisa para colocar em perspectiva o assunto que estou tratando. É compreensível que a cópia seja uma preocupação para eles. Do ponto de vista profissional, essa prática invadia a jurisdição dos designers, criando assimetrias no mercado profissional.

Mas, desde o ponto de vista 'da cidadania', também é explicável a preocupação que esses autores expressavam sobre a prática da cópia e o pagamento de royalties. Evidenciando o uso de elementos da crítica que circulavam na América Latina, a enorme maioria deles se pautava em elementos de reivindicação de uma 'industrialização coerente', como caminho para a autonomia econômica e cultural. Dessa maneira, o afã por determinar as fronteiras disciplinares e a regulamentação do exercício profissional estava fundido com as reivindicações permanentes sobre o como deve ser o modelo de desenvolvimento dos nossos países. Enquanto esses novos profissionais obtêm o monopólio da criação de produtos e sistemas de comunicação visual, se justificam para eles mesmos e para a sociedade à que pertencem, como o elo que vai dar sentido ao sistema de produção e independência da região.

Era a prática da cópia ocupando o lugar dos designers na prática profissional. Era ela como sintoma da dependência cultural. América Latina copia porque o modelo estabelecido fazia com que fosse importada a tecnologia. Essa importação engendrava pelo menos que aquilo que se projetasse respondesse à lógica imposta pela tecnologia: know-how, possibilidades técnicas, manutenção, etc. Igualmente, que ao serem trazidos de fora, aqueles bens reproduziam o princípio da descontextualização. Eram sistemas pensados para necessidades de outros cenários, que ao impor a sua lógica, reproduziam 
as determinantes nas quais eram pensados, sem se preocupar com as carências particulares do contexto... uma clara invasão das circunstâncias latino-americanas. ${ }^{42}$

Seguindo a lógica dos autores dos documentos, parece que ao se lutar contra a cópia como prática pelo menos essas duas coisas ficavam resolvidas, enquanto era visualizada a conquista das grandes ilusões latino-americanas. Substituir a cópia do estrangeiro, sugeria a criação de objetos que resolvessem as necessidades e carências reais da população, e, a partir desse axioma, impulsionar a criação de tecnologia local rompendo com a importação e toda a cadeia causal que daí provinha: inovação, desenvolvimento industrial e econômico, autonomia cultural

[...] el diseñador industrial en América Latina, deberá procurar su propio sustento en la pirámide del ejercicio profesional, por lo que las escuelas de diseño industrial, deberemos formar técnicos altamente capacitados, en el proceso de materialización de objetos [...] que resuelvan necesidades prioritarias de grupos marginados, en tanto esto no se logre [...] la crisis no se hará esperar [...] deberemos formar profesionistas capaces de diseñar objetos, de diseñar la tecnología para fabricarlos y que estos objetos satisfagan las necesidades prioritarias de México (Domínguez et al., 1976(?), p. 11).

Assim, para elevar a qualidade de vida das nossas sociedades era necessário quebrar os imaginários dos snobs da América Latina. Era preciso quebrar o paradoxal orgulho que denunciava Varsavsky... aquele olhar melancólico do norte como Meca. Projetar para nossas condições, evitando que outros projetassem para nós, seguindo os seus próprios interesses, como defendia o cubano Iván Espín.

\section{Elementos de uma comunidade}

Antes de terminar essa parte, considero que existem algumas coisas interessantes para destacar. De um lado, os enunciados que compõem essa última série -design e subdesenvolvimento- parecem responder a uma necessidade maior de argumentação se

\footnotetext{
42 "tanto as grandes quanto as médias e pequenas empresas tendiam a autarquia, resolvendo elas mesmas o desenho de todo produto ou pelo menos de algumas de suas partes. A encomenda de trabalho a profissionais ou escritórios especializados em design era insignificante nas grandes e médias empresas e inexistente nas pequenas [...] As pequenas empresas costumavam receber os desenhos de fornecedores e clientes. 0 pessoal que dentro das empresas cumpria as funções do designer, na verdade não possuía qualificação para as tarefas que exerciam. Era técnicos de nível médio, autodidatas improvisados dentro da própria empresa a partir de pendores naturais para o desenho" (Escorel, 1976, p. 6).
} 
comparados com as reivindicações nacionalistas ou com o debate sobre a jurisdição do design. É como se fosse suficiente fazer um exercício de argumentação sobre a realidade econômica e social, para deixar colocada a base dos argumentos.

Agora, essa claridade argumental não provém exatamente dos autores dos textos, este sendo o segundo fato interessante a realçar. Como abordei em vários momentos, tais conformações conceituais, os seus caminhos retóricos e as rotas causais, provêm de discursos de intelectuais latino-americanos que vinham criticando o processo de desenvolvimento regional desde -pelo menos- os anos 1940. 0 tempo de difusão que essas críticas completavam na região, assim como o seu latente espírito reacionário, permitiam entender o nível de compenetração dessas ideias com a maneira de ver o mundo assim como, visivelmente, o nível de apropriação delas por parte de muitos intelectuais da região por aqueles anos. Entre esses intelectuais, claramente incluídos os autores da documentação apresentada em Bogotá em 1980.

Por último, apesar das notórias diferenças em vários assuntos, chama a minha atenção a grande coincidência para assinalar preocupações, determinar linhas causais e até caminhos para resolver as grandes encruzilhadas da região, em indivíduos que moravam em lugares distantes e que só vão se conhecer durante o processo de conformação e funcionamento da ALADI. Vários filtros explicam essas coincidências críticas. Por enquanto vou deixar mencionadas as evidentes justaposições delas com as que levantava o PNUD na própria documentação do Congresso em Bogotá.

1.

O comitê colombiano de organização do evento convocou a representação do PNUD naquele primeiro congresso inaugural da ALADI. A palestra apresentada por Bruno Guandalini, Representante Adjunto del Programa de las Naciones Unidas para el Desarrollo en Bogotá, fez uma leitura do desenvolvimento da região, realçando algumas caraterísticas que faziam dele um processo bem particular. Várias dessas características já tinham se convertido em obstáculos dele, compondo um enorme paradoxo. Encima de categorias prefiguradas, Guandalini indica os graves vazios do desenvolvimento na América Latina vista como região 
[...] el marco socioeconómico en el cual se desenvuelven en América latina los países llamados "en vías de desarrollo", puede sintetizarse de la siguiente manera: 1) una notable concentración de la propiedad de los medios de producción y en general del ingreso y riqueza en un porcentaje reducido de la población; 2) condiciones de vida (consumo, salud, vivienda, educación, empleo, protección social, etc.), precarios para la mayoría de la población; 3) exportaciones poco diversificadas, sujetas a importantes fluctuaciones de los precios en los mercados internacionales, $y$ en general insuficientes para financiar las importaciones de los bienes de Capital, las materias primas, los productos semi elaborados y otros bienes necesarios para estimular el proceso de desarrollo; 4) considerable endeudamiento externo; 5) deficiente utilización del potencial agropecuario, debido estructuras de tipo latifundio minifundio que (excepto para los productos tradicionales de exportación) dificultan la modernización del sector y un aumento de la productividad, así como la incorporación económica y social de vastos sectores de pequeños agricultores y campesinos; 6) un proceso de industrialización caracterizado por: tendencias monopólicas en varias ramas de la producción industrial; la utilización de tecnología intensiva en capital importada, lo que a menudo redunda en capacidad instalada ociosa y merma nuevas oportunidades de trabajo; un mercado interno reducido debido a la deficiente distribución del ingreso, que impide la expansión industrial hacia nuevas ramas que requieren amplia escala de producción; 7) un elevado grado de dependencia económica y tecnológica externas; 8) un acentuado desequilibrio regional; 9) la existencia de fuertes grupos políticos de presión, con actitudes muy poco favorables al cambio, en vista de los grandes beneficios que reciben dentro del contexto de las condiciones imperantes (Guandalini, 1980, pp. 1 - 2).

Gostaria lembrar a trajetória que desenha aquela curva do Gráfico 1 na página 193 e que novamente acompanhasse o meu argumento.

Ao se observar o trecho citado pode se ver que com exceção de menções sobre o problema das exportações diversas, o endividamento externo ou as referências a um mercado interno reduzido -itens 3, 4 e segunda parte do 6 respectivamente-, a descrição acerca do marco socioeconômico apresentado por Guandalini em Bogotá, contém as mesmas categorias usadas pelos autores argentinos, brasileiros, colombianos, costarriquenhos, cubanos, guatemaltecos e mexicanos, para criticar o modelo no qual estavam imersos os seus países: concentração de renda, condições de vida, características da exploração agropecuária -quando ligada da concentração dos fatores de produção-. Todas essas características da dependência estrutural do processo de industrialização, assim como das tecnologias e da economia em geral, desequilíbrio regional e arrivismo, presentes nos enunciados dos autores presentes em Bogotá, quando configuraram a crítica do modelo econômico e social dos seus países. Visto 
assim, me parece suficientemente claro que as categorias de análise usadas pelos autores da documentação apresentada em Bogotá são as mesmas que usa o PNUD para fazer o diagnóstico da região.

Agora, por sua vez, o PNUD recolhe e oferece as preocupações que a ONU estabelecia sobre o desenvolvimento, seguramente fundindo categorias com outros dos seus escritórios como o PNUMA -Programa das Nações Unidas para o Meio Ambiente-. É importante dizer que a ONU também recebe elementos críticos de outros dos seus escritórios como a CEPAL, que fez fortes críticas ao processo a partir dos anos 1960. Segundo Bielschowsky (1998), orientadas no sentido metodológico, essas críticas afetavam as perspectivas teóricas com as que se tentava compreender o problema dos 'Estilos de Desenvolvimento', assim como a concepção da declaração do desenvolvimento social como objetivo da humanidade de 1969

[...] la CEPAL responderia oficialmente al mandato conferido por la Asamblea General de evaluar la estratégia de desarrollo integral en las condiciones latinoamericanas [...] el trabajo [de Balboa e Wolfe] formula una serie de critérios para el "desarrollo integrado" o "desarrollo humano", entre los que figuran, muy a gusto de la agenda reformista de los años sesenta, la defensa de la necesidad de modificar el régimen de propiedad de tierra y el control y la utilización soberana de los recursos naturales [...] destacando que el modelo o el estilo que se adopte debería ser orientado por la planificación estatal y contar con la participación indispensable de todos los estratos de la población (Bielschowsky, 1998, p. 19).

A CEPAL como um dos focos mais importantes a partir do qual a ONU e os seus escritórios conceituaram os problemas do subdesenvolvimento. Um foco de difusão de ideias, agendas e receitas que impactaram a realidade latino-americana nos mais diversos níveis desde finais dos anos 1940. Desse ponto de vista, seria apenas esperado que as categorias formuladas por Guandalini em Bogotá coincidissem com as usadas pelos autores dos textos e responsáveis de vários dos processos de profissionalização do design na América Latina. No final, eram as categorias desenvolvidas pelos intelectuais latino-americanos que pretendiam compreender as dinâmicas da economia e a sociedade da região no cenário mundial durante o século 20. Os níveis de consciência, a sua forma no discurso e os caminhos de apropriação, serão elaborações que talvez tenham aparecido na mesa quando da justificação da existência do design, no que as relações me parecem tão autenticas como originais. Nesse momento, na embriaguez do 
sentido do chamado, o design aparecera nos discursos desses autores apaixonados, como o elo e a causa faltante para que tudo funcionasse.

2.

Assinalar a tributação das categorias dos autores ao núcleo de teses da CEPAL ou às outras correntes críticas da época, não diminui o sentido ou a legitimidade dos enunciados dessa documentação, como tampouco enfraquece a importância das criações desse grupo de latino-americanos reunidos em Bogotá.

Pelo contrário, tributando essas ligações, acredito que posso explicar duas coisas. Primeiro aquela que depois do tratado já vira uma obviedade: a coincidência das categorias e até as tendências na hora de criticar a realidade na extensão de semelhante território, por indivíduos afastados entre si. Segundo, essa tributação explica a inexistência de referências nos enunciados, quanto à definição do design. Uma e outra coisa mostram que as ideias se expressam recriando um nível de inconsciência tal, que como teses, pertencem aos autores dessa documentação pela via da apropriação, pois em algum momento das suas vidas, viraram elementos com os quais enxergavam e resolviam o mundo.

Mas, as coincidências no uso daquelas categorias, enquanto deixa evidências contundentes de uma circulação regional de paradigmas, também permite pensar em que bem configuram um jeito especial de olhar a realidade na América Latina, se convertendo em características da maneira de conformar a crítica nesse lugar do mundo para um grupo de pessoas. Era um bloco de teses que conformava determinadas características de um pensamento latino-americano que, por sua vez, era fruto da mistura entre a percepção das circunstâncias, a experiência com o contexto e do diálogo com o que vinha de fora do território... um pensamento caracterizado pela hibridação, para fazer aqui apologia de García-Canclini (2015). ${ }^{43}$ Nisso termina envolvida uma forma de compreender e determinar o design na América Latina, para a América Latina... uma forma diferenciada e correspondente com as circunstâncias.

Estou ciente de que o tom dessa minha interpretação é maniqueísta e essencialista. Uso deliberadamente para me inscrever no sentido do grande conflito da época. Aquele

\footnotetext{
43 Fazendo analogia, do "texto" com uma ideia ou um grupo delas, acho ilustrativo o silogismo de Stanley Fish ao expor a passividade ou atividade de um leitor à frente de um escrito. Esse silogismo é o epígrafe com que abro esse capítulo.
} 
conflito no qual esses latino-americanos, autores desses documentos, parecem interessados em se somar também com essa escusa em Bogotá. 0 cenário da Guerra Fria seduzia esse tipo de maniqueísmo assim como esse esforço essencialista, tanto no olhar para América Latina, quanto dela para o mundo e, parece claro dizer, era um propósito perseguido pela maioria dos fundadores da ALADI em 1980. Era uma forma inconsciente de participar da reivindicação da existência dessa realidade chamada América Latina; uma forma desconforme com esse desdenhado olhar que se produzia sobre ela por causa da sua diferença com o avassalador espírito ascético-saxão. 


\section{ALADI, uma comunidade interpretativa}

[...] La Europa que consideró que su destino, el destino de sus hombres, era hacer de su humanismo el arquetipo a alcanzar por todo ente que se le pudiese asemejar; esta Europa, lo mismo la cristiana que la moderna, al transcender los linderos de su geografía y tropezar con otros entes que parecían ser hombres, exigió a éstos que justificasen su supuesta humanidad. Leopoldo Zea (México) 1953 (GEL, 2015, p. 1).

[...] Durante mucho tiempo se supuso -y muchos aún lo siguen suponiendo- que los americanos éramos sus herederos inmaduros, y esto ha permitido que seamos, como diría Zea, víctimas de la "humanidad de medusa" europea, de sus penetrantes ojos llenos de juicio frente a los cuales nuestra "presunta" humanidad era evaluada, medida, calificada. De este modo, fuimos convertidos en meros objetos, en una parte más de la naturaleza, en suma, en una humanidad de piedra (GEL, 2015, p. 1).

Eu quero fazer aqui uma pausa na narração para abrir um parênteses. Tanto o Capítulo 2 como o Capítulo 3, mostram a trajetória de algumas das ideias que deram forma a um projeto regional como a ALADI. Com as devidas proporções, cada um desses capítulos também deixa transparecer o coração dessas ideias como aquele elemento que talvez Max Weber (2006) chamaria de "vocação" e que a partir dele o que Richard Sennett sintetizou como "auto-sacrifício voluntário de longo prazo" de uma comunidade (2012, pp. 313 - 316). Esse coração é o que movimentava as ações desses atores.

A coincidência nas formas de pensar entre esse grupo de latino-americanos é interessante dada, entre outras coisas e para mencioná-lo de novo, a similaridade nas categorias de percepção com as quais criticam a sua realidade social, a semelhança do tom de seus discursos e as estratégias de enunciação, o fato de não terem se conhecido até o início do processo de fundação da ALADI -vários anos depois de que tais ideias já tinham começado a ser construídas por cada um deles- e por fim, pela similaridade de tudo isso na extensão de um vasto subcontinente, aparentemente desligado entre as suas partes. ${ }^{1}$

\footnotetext{
${ }^{1}$ Em uma ou outra medida, ao estar tão interessados na nossas relações com a cabeça do polvo, temos esquecido compreender as mutuas relações que estão-se dando entre os tentáculos. Tal vez, se mudarmos
} 
Nessa densidade é interessante ver como para eles o exercício do design era compreendido como uma atividade tecnológica. Um exercício intelectual norteado para a resolução das carências da população, principalmente das pessoas mais vulneráveis na sociedade, onde parece repousar o grande chamado do trabalho criativo -por sua vez muito ligado com os ideais do trabalho para os outros-. Demostrei anteriormente a coerência existente entre os postulados dos diferentes latino-americanos em Bogotá sobre isso.

Igualmente é necessário realçar o profundo sentimento nacionalista que acompanha o discurso dos fundadores da ALADI. Na maioria das ocasiões, partindo de uma reivindicação dos princípios culturais de cada pais, os envolvidos foram se aproximando da necessidade de construir um olhar voltado para o que era latinoamericano. É difícil achar forçada essa estratégia de argumentos, de fato parece organicamente articulada e sobretudo, coincidentemente presente nas ideias da maioria deles. É como se reivindicar a América Latina fosse recriar um grande senso comum -de certa forma é mais ou menos assim-.

Por fim, é chave compreender tanto a concepção do design como tecnologia quanto o sentimento nacionalista desses intelectuais como dois aparentes mecanismos para criticar, diagnosticar e se pensar a mudança da realidade. É um caminho para criticar e diagnosticar com base em uma série de ideias que são repetitivas uma e outra vez e que escassamente se justificam como argumento, além do formato dos enunciados de um manifesto. Todos criticam o pagamento de royalties e a cópia de modelos com as suas consequências tecnológicas: são práticas que explicam desde o subdesenvolvimento até a dependência técnica e cultural de cada um dos países, assim como da região em geral. Mas é realmente escasso o enunciado que apresente tal assunto como um problema. Não encontraremos essa 'lucidez' nos enunciados, entre outras coisas porque essas ideias também parecem circular como sentido comum nos diversos intelectuais latinoamericanos desde os anos 1940, anos nos quais as propostas da CEPAL abriram uma linha crítica e muito própria de perspectiva sobre o desenvolvimento.

É preciso considerar que existiam pelo menos três núcleos de onde puderam se irradiar essas categorias e que poderiam explicar tais similaridades. Esses núcleos tinham a sua própria dinâmica de digerir suas respectivas ideias, criando discursos a

a dicotomia cabeça-tentáculos para uma ideia de rede, vários sentidos explicativos apareçam, tal como acredita Jean-Louis Cohen (2006). Tanto a metáfora quanto a proposta de mudança são dele. 
partir de processos complexos e mais ou menos compridos, bem chamados de mestiçagem, como visto desde narrativas externas (Gruzinski, 2000), de hibridação como o problematiza García Canclini (2015) ou de antropofagia para fazer apologia de Oswald de Andrade. Um vívido modernismo era visível nessa crítica de intelectuais latino-americanos. Um modernismo que nesse caso transitava fortemente dentro dos paradigmas da Arquitetura Moderna e um pouco menos na Arte Moderna. Para sintetiza-lo, os ideais da criação para os outros embriagou toda uma geração de jovens estudantes de arquitetura desde os anos 1950 na América Latina. Dessa forma, tanto o ato criativo quanto o domínio técnico eram a favor da resolução dos problemas de terceiros. Ambas as coisas, promessas do desenvolvimento social.

Acompanhando esse ideal modernista é necessário mencionar uma longa conexão que ligava intelectuais latino-americanos na segunda metade do século 20 -como os da ALADI- com as reivindicações nacionais do século 19 e até mesmo, a lutas das últimas décadas do século 18 em determinados grupos de individuos. Com as suas respectivas variações, desde aqueles momentos várias linhas de intelectuais latino-americanos entraram no exercício de procurar e reivindicar aquilo que era próprio como mecanismo da configuração da identidade nacional. A criação da denominação "América Latina" até poderia explica-se por isso.

Nesses núcleos, a presença de ideias externas era tão importante, quanto o questionamento interno permeado pelos interesses de indivíduos apaixonados. Esse enfoque é tão vital como aquele da interpretação in loco. Por isso é difícil acreditar que tais núcleos sejam simples atualizações de influencias recebidas por agentes externos. De fato são invenções legítimas que pretendem olhar e criticar a realidade, assim como mudá-la.

Mas, assim como é importante a tensão que dá origem a aquela antropofagia, é necessário considerar que essas ideias ganham vida a partir das convicções de um grupo de indivíduos que por sua vez tem a sua própria história. No caso da ALADI, um grupo de pessoas que nasceram a partir do final dos anos 1930 nas cidades dessa América Latina -do pesadelo e da utopia-, que vai se apropriar desses discursos conforme as suas dinâmicas e interesses. Um grupo de pessoas que tiveram a oportunidade de construir uma experiência e uma sensibilidade por meio da qual se aproximaram a criticar a realidade que lhes rodeava. 


\section{Criatividade Social}

[...] Los modernos eran, por definición, enemigos de la clase dirigente cultural; necesitaban un adversário y, si éste no existía, se lo inventaban (Gay, 2007, p. 296).

\section{Criar para resolver}

1.

A maioria dos enunciados apresentados em Bogotá em relação à definição ou à defesa do design poderiam ser sintetizados na ideia de criar com o propósito de resolver as necessidades dos outros. Um ato criador diferente daquele ato individual onde a criação parecia concentrada no prazer do autor como um fim. Aqueles enunciados podem ser sintetizados no mote da Criatividade Social que por sua vez representa uma forte discussão histórica sobre o sentido que deve ou não governar os atos criativos dos 'filhos da modernidade', principalmente aqueles que seriam produzidos pelos arquitetos na sua forma contestatária e herética: a Arquitetura Moderna. ${ }^{2}$

Antes de avançar me parece prudente dizer o seguinte. Muitas das historiografias recentes que pretendem explicar os processos de formação do campo do design nos países latino-americanos insistem que o pensamento alemão faz parte do DNA do design na região explicando a sua existência. Refiro-me aqui às escolas de design, particularmente a HfG de Ulm.

Além da suspeita que me provoca a unidirecionalidade desses enunciados, assim como algumas percepções que tinha conformado pelo contato direto com fontes primarias dos processos latino-americanos de design, a mim me parece que privilegiar a

\footnotetext{
${ }^{2}$ Como exporei, o mote 'Criatividade Social' reúne sentidos que transitam como lugares comuns em círculos de arquitetos de metade do século 20. Não faço ideia de quem o acunhou. A primeira vez que me encontrei com esse termo estava sendo usado por Rómulo Polo em uma das suas reflexões em torno das relações do Design com o cenário social colombiano (Polo, 1980d). Logo o vi mencionado em documentos dos anos sessentas, relacionados com as Conferencias Latinoamericanas de Escuelas y Facultades de Arquitectura (Subcomisión-1, 1964). Suponho que procurando ainda mais em torno dele, encontrarei menções anteriores e posteriores. Sendo parte de um senso comum, o que me parece importante é o sentido no uso do termo nos atores e não a sua origem em sentido 'positivista'. Nessa ansiedade respira de novo a armadilha do mito de origem, do qual pretendo fugir despavorido.
} 
influência da HfG de Ulm, por exemplo, limita a compreensão da complexidade dos processos latino-americanos relativos ao design em geral e, muito mais aos relacionados com ALADI. Penso em duas razões principais.

Por um lado me parece um erro metodológico pensar que a ideia de epicentro é suficiente para explicar uma questão dessa complexidade. É preciso compreender que como fenômeno social, o design se explica pela densa e heterogênea trama de condições sociais na que se produz, e não, por apenas uma causa, uma determinação ou, para dizer assim, pelo traço de uma linha reta só. A imagem de um epicentro gerador reproduz a resignação que tem incorporada a ideia 'da Influência', que por sua vez engendra a figura colonial de civilização e barbárie aonde o Ocidente possui a lógica e os outros tem que lhe demostrar a sua humanidade. ${ }^{3}$

Agora, se a ideia de influência é limitada, atribuir o design como resultado de uma causa só é realmente artificial... descobre uma prática ideológica, para não dizer religiosa. Supondo que a ideia de influência seja suficiente, no caso do design latinoamericano e na particularidade da ALADI seria necessário incluir nessa fórmula pelo menos o Royal College of Arts de Londres e a Universidade de Syracuse no Estado de Nova Iorque, com as quais Ulm estava lutando a hegemonia do poder dentro do ICSID durante os anos 1960. No final, o ICSID foi a instituição que contratou boa parte dos projetos de assistência e cooperação com escritórios da ONU, que explicam muitas relações entre designers latino-americanos e estrangeiros.

Em segunda instância, a ideia de influência de escolas de pensamento internacionais limita a compreensão da complexidade da ALADI, dado que impõe a ideia de homogeneidade a um processo que, na realidade, mostra ser totalmente o contrário. Não só não existe uma única instituição na qual os latino-americanos viajaram a estudar design -ou assuntos relacionados-, como também não foi exatamente uma prática usual, pelo menos, não no mesmo nível. Numa listagem rápida de instituições estrangeiras nas quais estiveram presentes latino-americanos envolvidos na criação da ALADI desde os anos 1950, constam instituições como a Universidade de Boston, Yale, Syracuse, o Pratt

\footnotetext{
${ }^{3}$ Nessa expressão estou juntando duas fontes. De um lado uma poderosíssima ideia do filósofo mexicano Leopoldo Zea, que dá baseamento para uma linha latino americanista na segunda metade do século 20. Ela expressa que o ethos do pensamento Ocidental cobra 'a humanidade' dos entes diferentes dele (GEL, 2015). A segunda é uma expressão de Walter Mignolo, que justamente ironiza a arrogância desse olhar Ocidental quando relacionado com os outros "el esclavo conoce la razón del amo y la razón del esclavo, en tanto el amo sólo conoce la razón del amo puesto que el esclavo, precisamente, no tiene 'razón'” (Mignolo, 2009, p. 270).
} 
Institute de Nova Iorque, o Instituto Estadual de Arte de Florência, o Politécnico de Milão, o Belmont Adult School dos Ángeles, a Universidade de Stuttgart, o Helsinki School of Economics, o Massachussets Institutte of Technology, a HfG de Ulm -um ou dois casos-, a HfG de Offenbach, entre outras. ${ }^{4}$

Assim, essa abordagem é metodologicamente limitada e seria artificial tentar impô-la nesse caso. Mais do que demostrar um capricho construído a priori -no que pode ser visível desde uma estratégia politica e ideológica por determinar 'A versão dos fatos', quanto a necessidade de aceitação daqueles que compraram a necessidade de 'demonstrar a sua humanidade'-, eu prefiro crer que estou sendo receptivo às informações sugeridas pelas fontes primárias que tenho em mãos. Como se tentando perceber as pisadas deixadas pelo cavalo, tanto no solo, quanto nos ramos das árvores, assim como na ansiedade com a qual estava sendo procurado por várias pessoas, eu estivesse olhando as pegadas que deixou o cavalo desconhecido quando passou. ${ }^{5}$

Nos diferentes documentos que tenho nas mãos, vejo muitas mais linhas de influência... variados tipos de ideias que parecem entrar em diferentes momentos em uma caixa de ressonância, para usar a figura de Serge Gruzinski (2012). Nesse processo fica claro que a chamada influência que os postulados da Arquitetura Moderna exercem é maior do que qualquer escola de design. Um fato pode ajudar. Quando as escolas de design eclodem e lutam pela sua primazia internacional, os processos que deram origem às ideias que tem na cabeça os criadores da ALADI, já tinham iniciado o seu percurso de configuração. Alguns desses processos, de fato com várias décadas de antecedência e sem ser chauvinista, sendo originados na região, como tentarei mostrar nas seguintes páginas.

\footnotetext{
${ }^{4}$ Um grupo diverso de escolas e uma prática heterogênea no relativo aos níveis: os ALADIs tomaram nesses locais desde cursos de verão e graduação até alguns de mestrado. Como com tudo o relacionado com a ALADI e com a América Latina em geral, a mistura, a irregularidade, a mestiçagem, a hibridação é o que pode ser retomado como constante. 0 monolítico desmancha no ar.

${ }^{5}$ Estou reconstruindo a cena que apresenta Umberto Eco, quando Guillermo de Baskerville e Adso de Melk estão chegando naquele monastério onde transcorre a historia do "Nome da Rosa" (Eco, 1994). Como vejo, nessa entrada -como na extensão do romance-, entre muitas coisas Eco esta jogando uma epistemologia da pesquisa, na mesma linha na qual o seu compatriota, Carlo Ginzburg, reativou o sentido do que fosse debatido na Escola dos Anais, principalmente por Marc Bloch. Estou falando do trabalho sobre aquele moleiro italiano conhecido como Menoccio, quem foi processado pela Inquisição dada a sua cosmologia (Ginzburg, 1998). Como é sabido, essa pesquisa resulta publicada no livro "O queijo e os vermes", em 1976, quatro anos antes da publicação do romance de Eco sendo um dos baseamentos metodológicos da chamada "micro história". Um trabalho decididamente empírico -apoiado em fontes primárias-, focado em processos sociais de pequena escala, que resulta descobrindo grandes processos históricos por meio de um refinado trabalho de abdução.
} 
2.

$\mathrm{Na}$ tentativa de desenhar uma trajetória dos paradigmas que defendem os fundadores da ALADI, é preciso sublinhar que eles tenham se formado como arquitetos, em finais dos anos 1950 e durante a década de 1960, em universidades que não só estavam padecendo com o radicalizado e agitado debate político daquele momento, mas que estavam fortalecendo as apostas que tinham feito em seus cursos de arquitetura como programas modernos. De formas mais ou menos diferenciadas, os fundadores da ALADI tiveram contato direto e relativamente ampliado com a Arquitetura Moderna, os seus baseamentos, promessas, desafios e problemáticas. A base parece a mesma. Em um certo sentido, uma plataforma relativamente compartilhada por todos eles. ${ }^{6}$

Por sua conta, os seus exercícios de formação complementar são diversos. As particularidades que essa heterogeneidade oferece serão visíveis no processo. Mas no intuito de compreender as similaridades é preciso olhar algumas coisas no núcleo da Arquitetura Moderna como difusora de sentidos. No final das contas, ela parece ser a matriz homogeneizadora mais direta deles.

Uma primeira coisa é o fato de que esses arquitetos estavam se formando na região, em diálogo com preceitos que tinham chegado na América Latina com alguma antecedência -20 ou 30 anos antes-. Assim, quando aqueles estudantes tiveram acesso a esses preceitos, eles já estavam, pelo menos debatidos, atualizados, traduzidos, recriados ou até criados, reinventados ou cancelados. De fato, várias das coisas que aprenderam alguns dos mestres desses jovens aprendizes, nas suas próprias jornadas de estudo e de trabalho com os sacerdotes do modernismo europeu e norte-americano, já tinham sido 'testados' nas condições das problemáticas locais, com tudo o que tal depuração de princípios e teorias representou frente à experiência prática.

No princípio dessas ideias mencionei o mote da Criatividade Social. Fazendo uma busca nos arquivos, encontrei que em alguns documentos, alguns dos fundadores da ALADI mencionam esse mote como um dos significantes do papel do design no cenário regional. Indo um pouco mais atrás, encontrei como esse mote é relativamente comum em alguns arquitetos -mestres dos fundadores da ALADI- e é usado por eles como se

\footnotetext{
${ }^{6}$ Pelo apurado, só alguns membros pertencentes às primeiras delegações brasileiras na ALADI não se formaram em arquitetura. Contudo eles tiveram contato direto com os seus paradigmas, ao serem estudantes remissos dela -abandonaram pelo design-, praticantes do seu exercício ou ao ter sido membros de famílias com integrantes arquitetos... como Joaquim Redig cujo pai era, inclusive, amigo de Lúcio Costa (Redig, 2013a).
} 
fosse um mantra. Um vocábulo no qual aparece concentrado um gigantesco poder conceitual, tão complexo que demandaria muitas palavras e enunciados para poder contorná-lo. $\mathrm{Na}$ realidade, como acontece com vários enunciados dos arquitetos modernos, é mais ou menos comum encontrar esse tipo de expressões, motes, slogans, etc., como mecanismo para dizer rapidamente algo que demandaria muito trabalho para explicar. Quiçá a ideia de que o arquiteto não precisa de argumentos para demostrar as suas teses enquanto vai exibindo a teologia na qual estava apoiada a sua liturgia, também pode explicar a ausência de elementos racionais para a defesa de suas teses. ${ }^{7}$

Não sei quem falou primeiro sobre 'criatividade social'. Se a expressão é uma síntese de longos processos e conquistas, eu concordo com o sentido dele ser um mote denso em sentidos. Desde esse ponto de vista, estou interessado nessa expressão como significante de processos, que por sua vez, precisamente, lhe outorgam significado às ações.

\section{3.}

No decorrer do século 19, as dinâmicas que estava propondo a existência da máquina, tanto nos desafios produtivos, quanto no seu impacto nas migrações e no adensamento das cidades, eram sintomas de um processo maior que se poderia sintetizar no estabelecimento da Modernidade. Como é sabido, tal processo modificou os embasamentos, redefinindo a ordem social anterior, pelo menos em alguns países europeus. Assim, processos de desencantamento e secularização aconteciam e com eles a ciência da existência da cotidianidade, o conforto e o bem-estar, esse último generalizado por Giddens como o baluarte da modernidade, quando levado às implicações da vida de todos (Giddens, 1997).

Nesse esquema e em meio à indefinida qualidade de temas desenvolvidos de forma simultânea, tanto as prioridades de alguns governos para atualizar os seus territórios às expectativas do liberalismo econômico -laissez faire, laissez passer-, quanto o exercício material para responder a essas perspectivas, fizeram com que a prática de construir pontes, vias, estações de trens, entre outras, não repousasse necessariamente na

\footnotetext{
${ }^{7}$ Apontando aquela caraterística, Peter Gay assinala dois níveis "en vista de la sublime prepotencia característica de los principales arquitectos [...] 'Nada es más importante que el arquitecto"' Ao que logo depois agrega "a otros artistas también les gustaba explicarse en público, pero eran tímidos aficionados en comparación con los arquitectos de fuertes motivaciones ideológicas, que pretendían inculcar en los lectores sus puntos de vista con proclamaciones imperiosas y rotundos párrafos de una sola frase, carentes de matices" (Gay, 2007, p. 284 e 285).
} 
expertise do outrora prestigioso arquiteto. Ele já representava a formação de uma outra época. Desde as suas concepções do tempo -paradigmaticamente diferente com a ânsia que exige o padrão da eficiência na modernidade-, até o sentido pelo qual materializava uma obra, 'O Arquiteto' se tinha significado no anacronismo, e portanto, era sinônimo do passado.

Tais obras foram concebidas por outro tipo de profissionais. Artífices, nascentes engenheiros ou até arquitetos que, nesse caso, tinham quebrado as suas relações com a academia, principal foco de difusão daquele anacronismo. Pevsner (1992) o ilustra nos casos da ponte de Coalbrookdale, Shropshire (1771-1781), a ponte de Menai (18181826), a Biblioteca de Santa Genoveva em Paris (1843-1850) ou a Estação de St. Pancras em Londres (1864), expondo, no mínimo, uma relação diferenciada entre a forma daquelas obras e a sua função... botando na mesa um debate que foi agitado e relativamente prolífico durante as seguintes décadas.

Qualquer crítico que pretendesse compreender as condições nas que vive, encontraria na época, a noção e as suas implicações: o homem moderno começou a ter ciência da cotidianidade. De certa forma, pensou que a vida estava relacionada com o presente, pelo qual, o passado estava atrás e o futuro devia se configurar... já não estava dado. Fora da especulação geral, que já produziu letras suficientes, é importante mencionar aquele fenômeno para introduzir a ideia das necessidades expressadas na cotidianidade daquele homem moderno. Um indivíduo que 'exigia' que os objetos que lhe rodeassem cumprissem com a promessa de outorga-lhe bem-estar no momento.

Gay expõe a importância que Frank Lloyd Wrigth condensava na consideração do presente, onde se estariam dando as possiblidades do conforto "lo importante es la vida cotidiana -escribió a una de sus hijas en 1921-, no mañana o ayer, sino hoy. Nunca alcanzarás nada mejor del 'ahora' si lo tomas como se debe" (Gay, 2007, p. 283). Seguramente por causa da sua relação com o presente ele compreendesse as implicações -tanto materiais como emocionais- da criação para a vida das pessoas. Nessa linha e para seguir a Gombrich, foi precisamente ele que expôs pela primeira vez aquela importância no momento da criação arquitetônica 
[...] Quien habría de lograr ese triunfo sería el estadounidense Frank Lloyd Wrigth (1869-1959). Él se dio cuenta de que lo importante en una casa eran las habitaciones, y no la fachada; si aquella era cómoda y estaba bien proyectada por dentro, adaptándose a las necesidades de su propietario, con toda seguridad ofrecería también un aspecto agradable desde fuera [...] la casa tenía que derivar de las necesidades humanas y del carácter del lugar en tanto que organismo vivo (Gombrich, 2007, p. 558).

Dessa forma que as carências das pessoas foram mais importantes que o fato de recriar um estilo formal especifico. Atendendo às necessidades habitacionais das pessoas se declarava a importância de sua cotidianidade. Resolvendo-as, determinava-se a relação entre obra arquitetônica, satisfação de necessidades e bem-estar dando um passo em direção à conquista dos ideais da modernidade.

Obviamente a claridade desse assunto -que em realidade é a definição mesma do papel social da arquitetura em meio das circunstâncias propostas pela modernidadeera o estabelecimento do sentido pelo qual era importante a criatividade do arquiteto. Além da quebra com a prática anterior da Arquitetura, aquele estabelecimento também criou um debate sobre a forma da sua obra e as maneiras de consegui-la.

A grande maioria dos arquitetos modernos compartilhavam -explicita ou implicitamente- os mesmos preceitos. Contudo, parece de novo que Wright tenha se antecedido assim como sido mais claro e até mais denso do que seus contemporâneos. Para ele a honestidade, a simplicidade e a organicidade, eram os axiomas de uma arquitetura ajustada às condições que pedia o momento. Honestidade no sentido da sensibilidade com os materiais, sem pretensões de lhes esconder... cada um deles tinha a sua própria plástica, e seus próprios ajustes para ser transformados pelo movimento mecânico que exigia a máquina. Não é necessário -de fato é um ato de irresponsabilidade histórica- usar um material para simular outro. Simplicidade, no sentido de privilegiar a função pela qual é feita um prédio. A partir do aforismo de que o mais importante de uma casa é o conforto do seu usuário nas habitações e não a sua aparência exterior -que seria derivada-, fica evidente que a forma não responderia à embriaguez escultórica da especulação formal. Ela trabalharia em prol da satisfação... era criada para satisfazer. Organicidade, como princípio que pretendia o equilíbrio. Como se a satisfação das necessidades habitacionais não fossem segmentadas. Ou seja, era preciso desenvolver sistemicamente todos os elementos que interatuariam com o usuário 
[...] Para Wright, el diseño era una labor que lo englobaba todo: concebir una casa requería trabajar de dentro afuera [sic], procedimento que sus colegas arquitectos, tendentes a crear buenas impresiones superficiales, no habían acertado a adoptar [...] era una coherencia de todos los elementos de un diseño completo, que incluía los muebles y una íntima relación con la naturaleza, tanto el césped y los árboles como las sillas, las mesas y los pomos (Gay, 2007, p. 286).

Quando digo que ele tenha se 'antecedido', me refiro aos colegas arquitetos praticantes ao mesmo tempo que ele -nos finais do século 19 nos Estados Unidos- assim como ao fato de que Wright parece ser um dos arquitetos modernos mais lúcidos quanto à reflexão do seu exercício profissional. Não pretendo decifrar aqui a genealogia desse debate, nem privilegiar o lugar de um ou de outro arquiteto. Além dessa discussão, é necessário mencionar que as preocupações relacionadas com a honestidade, a simplicidade e até a organicidade da obra arquitetônica moderna, estiveram presentes na sua própria forma e proporções nas diversas posturas de Walter Gropius, Le Corbusier e até em Mies van der Rohe. As diferenças e o privilégio que outorga Peter Gay na citação, permite pensar que, apesar das similaridades, a arquitetura moderna não conformou-se exatamente como uma massa homogênea. De fato, os quatro arquitetos que menciono podem fazer parte de matizes bem diferenciados na maneira de compreender o problema da atualização moderna do seu ofício. Me parece importante realçar que, dado os diferentes níveis e suas experiências bem particulares, vários arquitetos latino-americanos tiveram contato direto com algum desses quatro arquitetos nas suas respectivas experiências internacionais. Se não parece fácil homogeneizar os seus postulados, também parece artificioso pretender defender a ideia de que a arquitetura moderna possa se explicar pelo epicentro ' $x$ '. Como disse, se chegasse a aceitar a verticalidade da arrogante ideia de influência.

4.

Nesse cenário, o debate sobre a linguagem era vívido, ele adquiria forma por causa da discussão do lugar que deveria ocupar a máquina dentro do processo de construção de uma obra arquitetônica. De fato -como é sabido- a atualização do discurso formal da arquitetura moderna se deve em boa parte à necessidade de se atualizar frente às possibilidades produtivas permitidas pela máquina, suas ferramentas e as suas lógicas. A conhecidíssima luta contra o ornamento passou por aí, e foi justificada ao usar esse tipo de ideias para apoiar as suas teses. 
A ideia da casa como uma máquina de habitar se liga esses princípios, enquanto deixa ver a quase obsessão de Le Corbusier com a técnica e a tecnologia na criação arquitetônica. De fato, seguindo Gay (2007) ou Collins (1970), esse aspecto permitiu pensar em uma das maiores contribuições de Le Corbusier como arquiteto moderno: o problema da produção massiva no processo arquitetônico. As condições nas quais estava imersa a sociedade obrigavam a sua atualização. Em parte, o sentido dessa preocupação também transitava nos imaginários de mais outros arquitetos como, por exemplo Gropius. 0 propósito final daquela problematização era uma combinação entre a atualização estética dos princípios propostos pela modernidade e os fins pelos quais um processo produtivo adquire sentido na era da reprodutibilidade, como mais a frente problematizaria Benjamin (2012).

Assim, a experimentação técnica vista como um fim, permitia que os "Sigfridos" pudessem visualizar a forma como se significava o lugar do seu ofício no cenário da mudança social de Ocidente. ${ }^{8}$ Mas, enquanto visualizavam tal coerência, esses arquitetos também conseguiam consolidar as aproximações sociais do seu trabalho. Logravam compreender os níveis de impacto da sua obra na vida das pessoas. Se viam como participantes ativos na mudança; se persuadiam com a ideia do ajuste histórico do seu ofício ao mesmo tempo que se embriagava com a ideia do rompimento com o passado. Para quem padece a embriaguez do chamado, perceber esse nível já era uma conquista da plenitude.

Em parte, em conjunto com o discurso formal -levado à síntese por Mies van der Rohe- também se determinava uma linguagem que permitiria que a noção de estandardização e reprodutibilidade era possível no trabalho arquitetônico. Tanto Le Corbusier, quanto Gropius, sacralizaram esses credos e, de forma semelhante, conquistaram a sua posição virando os seus sacerdotes. Era a oportunidade para a serialização da produção de unidades arquitetônicas, assim como para pré-fabricar peças para a sua configuração. Era a ocasião para resolver carências habitacionais repetidas, enfeitiçados pela lógica proposta na produção mecânica. A industrialização de elementos e de unidades arquitetônicas chegava como o cumprimento de uma promessa.

\footnotetext{
${ }^{8}$ A figura "Sigfrido - San Jorge" é de Collin Rowe (1978), quem constrói uma ironia respeito dos sentidos de chamado dos arquitetos modernos já, nos anos cinquentas. Uma ironia que pretende amostrar como a heresia com a que sentiam se parte da mudança social, simplesmente se transforma em maneirismo. Sobre isso voltarei em breve.
} 
5.

Assim as virtudes do produto moderno parecem consolidadas. Uma forma sem decorações, não especulativa; um sistema de produção que não oculta materiais e que por sua vez, compreendia a sua natureza e sua plástica; uma relação estreita entre linguagem e reprodutibilidade na lógica que exigia a máquina, oportunidade para a serialização e a estandardização; uma função não só não ignorada mas convertida em sentido pelo qual se dava a experimentação formal e o processo criativo. Um grupo de valores que atualizava o lugar da arquitetura nas circunstâncias da modernidade enquanto rompia com o passado.

Sem ser parte de um manifesto, compromissos que visavam o privilégio de carências habitacionais passando por cima do divertimento dos ricos e que eram destinados para enaltecer a cotidianidade doméstica, assim como a educar o gosto, "querían estar en sintonia con su tempo [...] remodelar su época de acuerdo con sus compromisos modernos" (Gay, 2007).

Há muitos escritos sobre esse assunto, nos tons mais diversos. Só lembrarei as preocupações de Hermann Muthesius naquele interesse pela educação do gosto. Elas trazem de novo -não afirmaria que era o seu objetivo- uma relação entre forma moderna e produção como um mecanismo para 'democratizar' tanto a feitura, quanto o consumo de objetos que resolverem necessidades cotidianas nas camadas em ascensão social. Também deixa entrever uma preocupação no intercâmbio econômico, relacionado com as práticas de exportação de bens produzidos. Em síntese, exibe um certo mal-estar com a não entrada em plenitude de uma modernidade que parece ser alheia do seu núcleo cultural alemão.

Para ele, o caminho de fuga do ornamento, a imitação de um material e a especulação formal, permitiam igualmente escapar do frenesi pelas aparências e a recriação do prestígio social; fórmula de substituição usada pelas burguesias no processo de ascensão social, as quais, no esquema mais infantil de arrivismo, pretendiam ser parte de uma aristocracia despótica e anacrônica

[...] Que quede claro que el arte industrial se encuentra frente a un deber educativo de primaria importancia [...] educar a las actuales clases sociales en la solidez, frescura y simpleza burguesas. Si lo logra incidirá de la forma más profunda en nuestra vida cultural [...] influirá diretamente en el carácter de la generación [...] [suprimindo] las tendências arribistas y pretenciosas (Muthesius, 2002) 
Tanto a arquitetura, quanto as suas especialidades derivadas -nas quais adquirira forma o design nos anos seguintes-, estavam diretamente relacionadas e incidiam na vida cotidiana das pessoas. Era o material didático da doutrina. Aí, assim como as decisões estéticas, o gosto começava a ser um elemento considerável no problema comercial que ele representava (Gay, 2007, p. 316).

\section{Criar para satisfazer}

1.

Aqueles princípios chegaram na América Latina de diversas formas. Não parece tão descabido afirmar que os fundadores da ALADI tivessem acesso a tais preceitos e debates, já traduzidos, reelaborados e até modificados e inovados, nos cursos de Arquitetura Moderna que eles cursaram desde finais dos anos 1950 nas universidades da região. Tanto nas estruturas acadêmicas desses cursos -relativamente depurados-, quanto na formação dos seus mestres -como disse há pouco, alguns deles discípulos e até colegas dos sacerdotes do modernismo internacional- assim como nas experiências profissionais deles - dos seus mestres, no qual tiveram oportunidade de confrontar os preceitos modernos nas exigências latino-americanas-, aqueles jovens conseguiram ser socializados nos preceitos defendidos pelo manifesto modernista da arquitetura, o qual, com total certeza, lhes deu elementos para organizar e tornar densa a crítica da realidade social à qual tinham estado expostos desde a sua infância.

Mas é importante mencionar que é justo pensar que tudo isso adquiriu forma a partir de uma vívida mistura. Se para Wright o princípio da criatividade estava concentrado na satisfação não segmentada das necessidades de um usuário, razão pela que defendia o princípio de organicidade -aquele que mostrava a necessidade de projetá-lo tudo em função do conforto-, é verossímil que esse princípio tenha adquirido determinados matizes no contexto da realidade dos diferentes países latino-americanos. Por exemplo, a segmentação não se concentrava em um usuário em particular e quem sabe, não se restringia ao projeto da sua habitação em harmonia com a natureza e o equilíbrio da obra arquitetônica com o mobiliário, as maçanetas e as janelas, como pregava Wright. Na circunstância latino-americana aquelas necessidades segmentadas expressavam um sentido que visava com as preocupações de classe social. É dizer, não a harmonia na obra como produto para um usuário, mas sim a sua concepção como 
oportunidade de resolver a "miséria e a pobreza" na região. 0 estabelecimento de regimes liberais e populistas com bases nacionalistas vai fazer complexa a fórmula e como estrutura, vai exigir consciente e inconscientemente das criações de todos os seus integrantes.

Quero expor na continuação dois exemplos que seguramente ilustram como tudo isso se concretizou-se na América Latina do pesadelo, exotismo e sonho. ${ }^{9}$

2.

Aproximadamente entre 1938 e 1939, Carlos Ferreira foi contratado pelo Instituto de Aposentadoria e Pensões dos Industriários -IAPI- como engenheiro-arquiteto. 0 instituto era um escritório do governo do presidente Getúlio Vargas, que, durante um momento determinado agiu como instituição de crédito imobiliário para os trabalhadores da indústria. 0 governo de Vargas, principalmente aquele desses anos chamado na história brasileira como Estado Novo, de 1939 a 1945- foi um governo direcionado para a modernização do Brasil, marcando permanentemente o que vários autores assinalam como a sua grande característica: um governo populista e nacionalista.

Por sua parte, Ferreira era um carioca -nome dado ao nascido no Rio de Janeiroformado em Engenharia Civil na Escola de Minas de Ouro Preto no Brasil, uma escola com um relativo espirito liberal, respeitosa do 'ideal do prático' exposto detalhadamente por Frank Safford (1989) como ideário das elites latino-americanas em finais do século 19. Citando Carvalho, Botas defende que aquela escola procurava, já nesse momento, quebrar com a tradição livresca, conciliando o aprendizado teórico com a experiência prática (Botas, 2012, p. 15). Perceptivelmente, aquela linha na qual parecia estar interessada parte da elite, pelo menos aquela que compreendia na infraestrutura e no comércio internacional a possibilidade para o desenvolvimento das nascentes repúblicas da região.

De volta ao Rio de Janeiro, Ferreira complementou sua formação na Escola Nacional de Belas Artes -ENBA-, onde obteve o seu título em 1935. Para esse momento, Ferreira se aperfeiçoou como arquiteto na matriz curricular resultado da reforma feita por Lúcio Costa naquela escola. Uma reforma que -entre vários aspectos- conseguiu se emancipar das tradicionais Belas Artes, enquanto eram incluídos no seu núcleo

\footnotetext{
${ }^{9}$ Aquelas qualidades da América Latina é uma expressão é de Elizabeth Cancelli (2003).
} 
discricional, boa parte dos debates modernistas que aconteciam nesse momento na Europa e nos Estados Unidos. Poderia dizer que se algo estava muito claro nos paradigmas de Ferreira, por causa da qualidade daquela dupla formação, era a ideia de que a forma de um edifício é um suporte material para a função pela qual ele era pensado. Os engenheiros da época tinham claridade absoluta de que o serviço da sua respectiva obra superava a sua especulação plástica. Os arquitetos modernistas, em base da sua atualização vocacional, também tinham adotado aquele mesmo preceito.

As diversas preocupações modernistas pareciam estar na mesa, tanto no esquema ideológico da Escola reformada por Costa, quanto no trabalho desenvolvido por Ferreira no IAPI. Ao menos naquele projeto que parece ter sido o primeiro: o sistema residencial de Realengo no Rio de Janeiro, desenvolvido entre 1938 e 1943.

3.

Desafiados pela realidade de um projeto da envergadura de Realengo, uma boa quantidade de conceitos debatidos e experimentados nos centros culturais do modernismo arquitetônico com certeza iriam se traduzir em operações materiais que escapavam da elucubração.

Tanto os problemas de uma linguagem considerada nos seus mínimos detalhes, quanto os desafios produtivos puxados pela industrialização, explicariam que tais atualizações tivessem lugar na lógica de Ferreira. Além das formas como foi ou não tradutor desse debate na exótica América Latina, parece importante ver como as condições do projeto materializaram tanto as expectativas modernistas mais gerais da obra arquitetônica, quanto a sua participação na mudança e a busca pelo 'bem-estar para todos'.

As exigências do projeto em Realengo obrigaram a construção de 2344 unidades residenciais, a baixo preço -correspondente com as possibilidades de pagamento dos futuros usuários que eram obreiros- projeto que, além disso, deixasse relativamente prontos os princípios para serem replicados nos diferentes projetos de moradias que o governo tinha se proposto daí para a frente: "A preocupação central do arquiteto foi a estandardização e a produção em larga escala, buscando o barateamento do produto final com a inovação tecnológica" (Botas, 2012, p. 10).

Os projetos arquitetônicos da larga escala na concepção produtiva iam se impor, em parte nascidos de forma imposta, em parte na vocação dele como arquiteto moderno. 
Era necessário organizar o sistema produtivo, onde os princípios da serialização e da modularidade respondessem organicamente às exigências, assim como a tentativa de estabelecer um sistema Fordista de produção e a inserção de novas técnicas no processo. Aí, em diálogo com esses princípios, a estratégia da fabricação prévia de determinadas peças -grande característica nessas circunstâncias- daria uma grande mão para que o objetivo fosse alcançado.

Era a ativação de uma cadeia causal, onde a necessidade pela larga escala, impulsionava o princípio da padronização, assim como a eficiência produtiva. Uma e outra coisa permitiram um equilíbrio entre qualidade - no final das contas era o projeto de moradia de uma grande quantidade de pessoas que representavam 'o povo'- e o custo, o que claramente promoveria o acesso de uma camada social que tinha recursos escassos. Esta claro que aqui, a forma do prédio passava a ser realmente uma desculpa. ${ }^{10}$

A ativação dessa cadeia causal dependia da inovação tecnológica. É claro, era a experimentação tecnológica a que permitiria a materialização das peças, os módulos e os tipos assim como a sua reprodução seriada. Uma construção rápida, com custos baixos, que fossem coerentes com as necessidades do projeto

[...] A pesquisa do custo mínimo levou-me a considerar alguns materiais pouco usados até agora entre nós. Quero me referir principalmente ao emprego de blocos prensados de concreto usados em substituição aos tijolos comuns de cerâmica e às placas compensadas e revestidas para divisões internas. As vantagens econômicas são consideráveis e quanto às qualidades técnicas dos materiais em apreço, a construção de um grupo experimental confirmou inteiramente as previsões feitas. Carlos Ferreira em 1940 (Botas, 2012, p. 33).

4.

A pesar da circunspecção desse caso, vários elementos me lembram experiências parecidas -bastante parecidas- de projetos feitos na Colômbia. Só mencionarei que alguns anos depois de inaugurado Realengo -apenas dois ou três- o arquiteto colombiano Hernando Vargas, projetou com ajuda de Raúl Ramírez -chileno- a máquina CINVARAM, que permitia compactar determinados materiais extraídos do solo, com o propósito de lograr uns blocos prensados que substituíram os materiais tradicionais que por sua vez encareciam as unidades de moradia campesina. Projetos e preocupações nos quais trabalhou Vargas como funcionário do Instituto de Crédito Territorial -

10 Ao representar 'o povo', representavam a nação e a ideia de serem a Igreja de Deus. Grandes misticismos misturados que ajudam a configurar a identidade na América Latina. Mais a frente desenvolverei uma e outra coisa. 
aparentemente escritório colombiano homólogo com o IAPI brasileiro-. Essa inovação, da mão dada com algumas outras no processo de organização, serialização e modulação, permitiram que o custo das casas baixassem entre um 30 e um 40\%

[...] Comencé a trabajar en mi profesión para el Instituto de Crédito Territorial, en un programa de vivienda campesina, y me apasionó el tema [...] ahí trabajé dos años haciendo casitas, las más baratas. Llegué a hacer una de $\$ 600$, pero no el metro cuadrado, sino toda la casa (Vargas, 2004, p. 34).

Não é de se estranhar a similaridade entre o projeto de Ferreira e a experiência de Vargas nos mesmos anos. Esse tipo de processos estavam sendo vivenciados em vários países da América Latina, com uma relativa simultaneidade ou em anos sequencialmente seguintes. Salvas as devidas proporções e diferenças arquitetônicas e urbanísticas a que respondiam, poderia mencionar a Unidad Santa Fé na cidade do México (1954-1957), a Unidad Vecinal Portales em Santiago do Chile (1954-1964), os chamados Bloques de 23 de Enero em Caracas, Venezuela durante os anos 1950, o Edificio de Viviendas Colectivas de la Cooperativa "El Hogar Obrero" em Buenos Aires, Argentina (1941-1951) ou o Barrio La Fragua em Bogotá (1958) entre muitos outros. Era como um espectro percorrendo a região em um momento bastante particular no que se refere ao seu processo de modernização.

5.

Não quero terminar a minha descrição de Realengo sem realçar uma outra característica do projeto, que também resultara significativa para o meu argumento mais a frente. Dentre as qualidades reconhecidas por Botas no projeto, a ordem racional produtiva, as suas derivadas necessidades de reprodução e barateamento, se somavam tanto às que ela reconhece como inovações formais -ao meu ver uma relativa atualização dos debates modernos de arquitetura- como também um certo essencialismo cultural -sou eu quem assinala esse termo para o que ela defende-.

Tanto o debate do espaço mínimo e as restrições da linguagem formal assim como o lugar da máquina e a sua lógica na criação arquitetônica, interpretam umas expectativas sociais que vinham sendo estabelecidas pela modernidade. Mas em Realengo elas estavam claramente compreendidas nas condições da realidade do Rio de Janeiro, dentro do panorama do Brasil daqueles anos... estavam sendo traduzidas para essas circunstâncias. Se aqueles princípios abstratos pretendiam a conquista de 
sociedades modernas, nas condições de Realengo -talvez pela ansiedade moderna também por realçar o exótico- Botas anota um esforço no resgate e em levar a um outro patamar os elementos e os procedimentos tradicionais, vistos como exotismos e concebidos como tipicamente brasileiros e distintamente cariocas.

Não poderia ser diferente. Lembro de novo de Stuart Hall (2008), quem por sua vez segue a Hall Foster, quando relaciona aquela busca pelo exótico como uma característica tipicamente moderna. Esses intelectuais dos que falo nessa parte do argumento são, além das diferenças, personagens modernos. Uma da suas qualidades, está estreitamente ligada com aquele exotismo que sublinha Foster, encontrado neste caso de Botas, e exposto por mim em vários trechos desse meu texto. Isso é importante. Um vigoroso nacionalismo acompanhava as cruzadas intelectuais desse ampliado grupo de latino-americanos

[...] Materializado na combinação da paginação dos blocos de concreto, produzidos por uma moderna máquina trazida dos Estados Unidos, com as telhas de barro, advindas das antigas tradições construtivas brasileiras [...] de acordo com as reflexões teóricas delineadas por Lúcio Costa [o tipo de casa geminada com telhado de duas aguas de Realengo lembrando a da casa do colono rural] era adequada e, por tanto, bela [...] [assim] o arquiteto [Ferreira] empenha-se em combinar os preceitos arquitetônicos debatidos pelo grupo carioca [a ENBA orientada por Costa], sobretudo a preocupação de forjar a identidade cultural do Estado Nacional, com as necessidades pungentes de habitação operaria em massa (Botas, 2012, pp. 11, 34, 35).

É possível dizer que naquele projeto e naqueles que se lhe parecem na região na época, se terminassem encontrando dois tipos de homens que poderiam ser confundidos como dois perfis de uma forma da modernidade daquele momento na América Latina. Em uma mão 'o populista' que pretendia 'dar aos outros' dentro de um esquema como o que Richard Sennett (2012) sintetiza: na embriaguez da solidariedade -vertical, paternalista, que responde a os anseios do provedor-. Na outra, 'o humanista' que se supunha sensível à ideia da prosperidade ilimitada para todos. Podem ser falsamente divididos. Por um lado, porque no fundo as duas linhas de pensamento parecem repousar na base de um modernismo ocidental homogenista que os produz. Por outra porque a ilusão dessas características nesse meu exemplo de Realengo, indicaria que o primeiro é Getúlio Vargas e o segundo Carlos Ferreira. Em realidade, uma e outra característica está em cada um deles pelo qual cada um responde à ilusão 
do chamado conforme as categorias com as quais percebe o mundo e as habilidades e as técnicas com que pode intervi-lo.

O engenheiro-arquiteto e o político, igualmente entendidos como modernos, estavam interessados em resolver as carências habitacionais de camadas populacionais menos favorecidas. A sua maneira, cada um deles terminou impondo formas de resolver aquilo que eles, nos seus escritórios, reflexões e falas, pensavam ser graves problemas.

6.

Tentando finalizar essa ideia, quero expor alguns detalhes do curso de arquitetura da Universidade Nacional em Bogotá como segundo exemplo. Não me estenderei, considerando que já tratei vários pontos gerais do debate moderno dentro da arquitetura como disciplina e profissão, assim como da maneira como em meio de uma vívida hibridação, esses e outros conceitos se materializaram nas exigências sociais da América Latina. Se o debate geral poderia ser compreendido como a base da definição discricional e jurisdicional da arquitetura na frente das mudanças do Ocidente, a materialização exibia algumas das formas como isso foi assumido nas condições da realidade do exemplo de Realengo no Rio de Janeiro, demonstrando algumas características do exercício profissional concreto... aquele que configura a experiência e fortalece a maestria. ${ }^{11}$

A chamada Faculdade de Arquitetura até os anos 1960, desprendeu-se da Faculdade de Engenharia em 1936, inaugurando-se -como parece- com uma certa briga interna entre a corrente moderna da disciplina e um grupo de ideias que ainda defendiam uma prática neoclássica. Quiçá, dois dos mais importantes representantes desse debate tenha sido o austríaco Karl Brunner (1887-1960), claramente neoclássico e o alemão Leopoldo Rother (1894-1978) deliberadamente modernista. É possível que em torno deles tenha se configurado a luta conceitual europeia sobre a função da

\footnotetext{
${ }^{11}$ Para esse pequeno aparte, tomarei algumas considerações, referencias e reflexões do meu livro "Creatividad Social. La profesionalización del Diseño Industrial en Colombia" (Buitrago, 2012). Nesse texto, considerei pertinente fazer uma rapidíssima genealogia da ideia da Criatividade Social -como no caso da ALADI, presente nos argumentos dos encarregados da profissionalização naquele país- o que me levou até a Faculdade de Artes da Universidade Nacional em Bogotá, epicentro académico dos atores do problema que deu origem ao livro. No arquivo inativo da faculdade, encontrei uma vasta qualidade e quantidade de documentação que da conta de inúmeros processos das artes, a arquitetura e o design -até da engenhariaproduzidos desde os anos 1920 tanto na Colômbia, como na América Latina.
} 
arquitetura e a sua atualização formal nessa escola. Para quem compreende que o que vem do exterior explica os processos na América Latina, isso seria suficiente.

Porém, essa disputa dialoga tanto com as tradições da prática europeia na arquitetura de Bogotá desde o século 19, como com debates que certamente oferecia a experiência de vários engenheiros colombianos da segunda metade do mesmo século. Da mesma maneira, e alinhado com o que tento problematizar, o debate dialoga com as experiências que adquiriam os diferentes arquitetos formados durante os anos 1930 e 1940 com os sacerdotes modernistas.

Tudo isso, em vívido sincretismo, me permite pensar na chegada do debate modernista da função social da arquitetura frente à máquina e as suas implicações na forma... explica tanto a atualização da linguagem arquitetônica, quanto a problematização do sentido da ideia promulgada por Sullivan -a forma segue a função-. No contexto, propôs e submeteu à reflexão em torno do sentido da criação arquitetônica.

7.

Quem dá uma olhada na estrutura do curso de arquitetura da Nacional, encontra desde finais dos anos 1940 uma claridade relativa no programa sobre as habilidades estimuladas nos futuros arquitetos. ${ }^{12}$ Aparece uma determinada necessidade por incluir os estudantes no projeto de objetos arquitetônicos caraterísticos do processo de urbanização moderna. Nas ementas de várias dessas disciplinas o treinamento do estudante, embasado na aprendizagem do aprender fazendo, girava em torno da projetação de moradias, fóruns, escolas, crachás, prédios de apartamentos, entre muitos outros. Objetos arquitetônicos que impulsionariam a modernização, permitindo a entrada dos indivíduos nos aspectos da modernidade que menciona Peter Gay a partir das ideias de Marinetti (Gay, 2007, p. 280 e 281).

Ainda interessante, pelos significados que tem na trajetória, o que vale a pena realçar é a base de onde eles deviam partir nessa estrutura das disciplinas. Se o objeto arquitetônico pode se ver naquelas ementas como um fim predisposto desde o início do processo pelo professor, está claro que a maneira e os detalhes, deviam responder às condições percebidas pelos estudantes na relação expressada pela comunidade que ainda aprioristicamente- precisava daquelas obras na sua cotidianidade. A disciplina de

12 Existem vários vazios na documentação que poderiam se explicar pelo passo do tempo, assim como pelas mudanças de expectativas burocráticas. 
Projeto de Arquitetura, determinava as expectativas materiais do exercício, mas dispunha a situação para que os seus estudantes se familiarizassem diretamente com as pessoas morando na sua respetiva realidade.

Os arquitetos mencionados e outros europeus consagrados foram professores dessa geração de estudantes, e também foram alguns daqueles primeiros arquitetos colombianos que, desde 1942, estavam voltando das suas experiências internacionais. Dessa maneira, tanto as reflexões e experiências daqueles alemães, austríacos, franceses, italianos etc. assim como desses colombianos, estavam inseridos na cena acadêmica na prática daquelas disciplinas. Hernando Vargas tinha acumulado a experimentação com a serialização produtiva construindo aquelas unidades de moradia campesina; Hernán Viecco tinha trabalhado na UNESCO em Paris com Marcel Breuer, Pier Luigi Nervi e Bernard Zehefuss e Germán Samper, quem trabalhou com Le Corbusier nos projetos do plano padrão para Bogotá, o projeto urbanístico para Chandigarh e outros em Paris, desenvolvia o projeto "Barrio La Fragua" em Bogotá em 1958. ${ }^{13}$ Álvaro Ortega ao voltar de Harvard em 1945, se converteu gradualmente em um dos mais consagrados inventores da construção colombiana e latino-americana. ${ }^{14}$

Uma sensibilização técnica que acompanhava uma preocupação social. Como se ao ter aprendido a linguagem, o sentido fosse conquistado nas condições que impõe a realidade do contexto de cada um, digerido por um processo de antropofagia tão crítico como relacionado... uma depurada forma de resolver as necessidades nas condições. ${ }^{15}$

No intuito de sensibilizar os estudantes para o projeto de objetos relacionados com a modernidade e com base na necessidade de conhecer as determinantes dos usuários das suas obras nas condições em que habitam, o curso de arquitetura da Nacional apostava na formação de habilidades concretas, coerentes com um determinado papel social da arquitetura que obviamente correspondia à visualização de um tipo de arquiteto. Por razões que não consigo estabelecer, tais claridades apareceram alguns

\footnotetext{
13 Esse projeto era o primeiro de uma linha de interesse na moradia popular. Mais a frente faria a urbanização Carimagüa (1965) e o concurso Previ-Lima em 1968 (Gutiérrez, 2004, p. 126).

${ }^{14}$ Segundo Gutiérrez, Ortega trabalhou no Centro Interamericano de Vivienda entre 1954 e 1956, foi pesquisador associado na Universidade McGill entre 1970 e 1973, assim como consultor na ONU, OEA e CEPAL (Gutiérrez, 2004, p. 125).

15 Além de se efetivamente foram professores de determinadas camadas de arquitetos, o seu trabalho já estava no meio sendo objeto de crítica -como falando de outra coisa Rowe (1978) diz: os prédios estavam ai como evidencia-.
} 
anos depois -principalmente em 1970- quando o perfil é rotundamente definido nos documentos do curso. ${ }^{16}$

Mas, acompanhando essa reflexão, no arquivo inativo da faculdade também repousa um documento, a memória de um congresso realizado em 1964 na cidade de Córdoba na Argentina. Como antecedendo tudo que tento compreender nessa pesquisa inteira sobre ALADI, naquele congresso, uma comissão de arquitetos latino-americanos fazem a tarefa de definir o qual é o papel do arquiteto. Me parece que as coincidências entre o seguinte trecho e vários dos enunciados que expus no capítulo anterior, já não parecem simples acasos. Acredito que não há necessidade de se realçar as passagens... já que se mostram por si mesmas

[...] El arquitecto: es el professional, que orientado a la organización de espacios significativos, en los cuales ha de transcurrir la vida del hombre planteados en función de sus necesidades vitales, ha de poseer un serio domínio de su técnica, una certera concepción integradora, y una desarrollada capacidad de creación, así como el más profundo conocimiento del médio y sus problemas. Una conciencia clara de los objetivos hacia los cuales debe tenderse para satisfacer las reales necesidades de la sociedad (Subcomisión-1, 1964).

Com as variações necessárias, essa base estava presente na estrutura conceitual que forma os paradigmas de Carlos Ferreira no Rio de Janeiro. Uma estrutura que permite pensar que não é descabido pensar que Lúcio Costa, Carlos Ferreira, Hernando Vargas, Germán Samper e Álvaro Ortega não só podiam representar uma forma de entender a arquitetura no Brasil e na Colômbia, mas também a concepção e o exercício de uma forte linha de arquitetos na América Latina.

\footnotetext{
16 "la organización del espacio para satisfacer de una manera real las necesidades físicas y emocionales del hombre, la creación de establecimientos y equipos que alberguen las funciones del habitar, trabajar, circular y cultivar el cuerpo y el espíritu, implican una orientación en la carrera de arquitectura en donde el análisis de los problemas humanos, complementado con una información técnica indispensable, estimule el proceso creativo de síntesis que debe traducirse en proposiciones que tengan una trascendencia propiamente arquitectónica" (AUN, 1970).
} 


\section{Tecnologia e circunstâncias}

[...] Em 1956, a CEPAL expressara suas primeiras dúvidas sobre se a indústria, na região do mundo com maior crescimento populacional, podia absorver o excedente de mão de obra da agricultura [como observara Celso Furtado em 1966 -já aludido por Prebisch em 1963-] o problema, em parte, era a tecnologia poupadora de trabalho que a Periferia importava do Centro [...] na América Latina, no século XX, ao contrário da Europa do século XIX, a tecnologia era exógena à economia regional e destinava-se especificamente às necessidades dos países desenvolvidos (Love, 2011, pp. 209, o realce é meu).

[...] A cada Proyecto Nacional corresponde un estilo tecnológico óptimo [...] un conjunto de características cualitativas generales, comunes a todas las ramas de la tecnología (y la ciencia), deseables porque son directamente deducibles de los objetivos nacionales, y prácticas, en el sentido que ayudan a tomar decisiones pues no son compatibles con cualquier propuesta. Oscar Varsavsky (Argentina) em 1974 (Roldán, 2010, p. 12).

\section{Espelhos da miséria}

1.

Como mostrei varias vezes, a argumentação dos fundadores da ALADI homologa o design com a tecnologia, de onde ativa-se uma espécie de fórmula ou cadeia causal na qual a independência tecnológica permitiria o rompimento com a dependência econômica e cultural dos 'nossos povos'. Igualmente, também esclareci que a geração -e produção- nas circunstâncias e para as circunstâncias garante a conquista do ideal da criação: que tudo aquilo que se produzir, responda às necessidades reais do contexto, alcançando assim a qualidade de vida e o bem-estar das pessoas, especialmente aqueles que estão na periferia do processo de desenvolvimento. Tudo isso enquanto se vai acumulando o conhecimento que permite tais transformações.

Assim, a satisfação das necessidades dos marginados, resolução das problemáticas industriais e a concepção do design como ferramenta das necessidades econômicas, eram argumentações por meio das quais, aqueles intelectuais em Bogotá definiram o papel do design como tecnologia no nosso contexto, como mostrei no capítulo anterior. 
Com essa 'fórmula' eles parecem pretender a superação do subdesenvolvimento, bem acima de uma forte defesa da região como um território.

A fórmula afirma tacitamente que o desenvolvimento da tecnologia é a base para a conquista do bem-estar. De certa forma, esse é um axioma que mora no coração do Projeto Moderno em si. Está mais ou menos claro que por aí vão as preocupações tanto dos intelectuais convocados em Bogotá, como de várias camadas de latino-americanos que vinham refletindo sobre essas questões desde os anos 1940. A ciência e a tecnologia como base para o desenvolvimento econômico e social. Uma dinâmica que estimula a transformação socioeconômica, assim como eleva os níveis de produtividade e a eficiência

[...] El avance científico y tecnológico ha llegado a constituir el elemento dinámico central de las economías modernas, tanto de la socialista como de la capitalista, para elevar la productividad, el volumen del excedente y la capacidad de satisfacción de las necesidades individuales y colectivas (Sunkel, 1970, p. 77).

O trecho anterior proveem de um encargo atribuído ao autor pelo Banco Interamericano de Desenvolvimento e que foi apresentado por ele mesmo na Conferencia Latinoamericana de Planeamiento Universitario no Chile em setembro de 1969. Esses eram os anos do debate sobre as oportunidades, os desafios e sobretudo os fracassos presentados pelas politicas de desenvolvimento na América Latina. Reflexões que debatiam e misturavam desde a pretendida objetividade do analista progressista quanto o espírito reacionário da crítica revolucionária. Sunkel, chileno, era parte do grupo de intelectuais que se reuniu na CEPAL durante esses anos. De fato, ele fundou e orientou o escritório da CEPAL no Brasil entre 1959 e 1961.

O problema, inserido dentro da crítica de vários latino-americanos da época, é que em meio desse ideal, o axioma não se reproduz na realidade da região por causa da sua posição dentro do chamado "Sistema Internacional de Comércio", questão que aprofundarei mais à frente. Essa posição condenava a América Latina a um estado de subdesenvolvimento e dependência permanente com os países "do Centro".

2.

Posso extrair dois princípios do trecho de Sunkel. De um lado, a ligação que estabeleceu entre o avanço cientifico-tecnológico e o melhoramento da produtividade. A segunda, que por enquanto me interessa tratar, a ligação entre aquele avanço e a 
satisfação das necessidades individuais e coletivas. Parece-me importante notar como uma e outra ideia estão presentes nas reflexões sobre o papel do design, nos argumentos das delegações em Bogotá.

A geração de tecnologia local, embasada nas capacidades locais e sobretudo, respondendo às necessidades locais, era um preceito que parecia cada vez mais rotundo no eixo argumental que pretendia compreender as condições sociais pelas quais ALADI se deu. No Capítulo 2, mencionei o documento de Vicente Sánchez, expondo as ideias que repousavam no seu núcleo. Elas eram exatamente as preocupações desse trecho de Sunkel, ainda fossem elaboradas entre quatro ou cinco anos depois. Um grupo de enunciados que defendiam contundentemente a aproximação crítica no problema da chamada transferência tecnológica.

Tanto no documento de Sánchez, quanto nesse de Sunkel, era defendida a ideia da geração local de dispositivos materiais como mecanismo que permitam a fuga da dependência com "o Centro". No caso de Sunkel, como caminho para defender a posição que deveria ter a universidade latino-americana como agente gerador. Em Sánchez, com o propósito de defender uma postura crítica sobre a transferência de tecnologia como ilusão para resolver problemas de comunidades rurais latino-americanas.

Em geral, tais argumentos percorrem mais ou menos a seguinte lógica. As relações entre a América Latina e, primeiro a Inglaterra e logo depois os Estados Unidos, tinham se estabelecido de tal forma que os últimos terminaram se convertendo no centro gerador de ciência, técnicas, valores e ideologias, enquanto a região, enviando para eles bens primários -banana, café, carne, etc.- foi se estabelecendo como um ente receptor. 0 chamado Centro gerava novo conhecimento e nova tecnologia traduzido em novos produtos, novas formas de produção, nova maquinaria e equipamento, até a publicidade necessária para criar e dinamizar os mercados para as mercadorias. Por sua vez, nos melhores casos, os países da região conseguiram se encarregar das etapas finais da produção de algumas daquelas mercadorias -principalmente automóveis e vários tipos de eletrodomésticos-, instalando as subsidiárias das companhias estrangeiras no território, importando as suas maquinarias e os seus insumos, até usando as suas marcas, licenças e patentes -em alguns casos comprando-as, em outros simplesmente copiando-as-. Era uma estratégia de desenvolvimento por reflexo que não impactava o avanço das indústrias nacionais, portanto, que não permitia o desenvolvimento econômico e social. 
Uma dialética entre inovar ou imitar convertida na principal causa, tanto da expansão dos mercados internacionais dos Estados Unidos, vários países da Europa e Japão, quanto do problema do subdesenvolvimento

[...] Debemos por tanto esforzarnos en llegar a tener una economía basada en la innovación más bien que en la imitación, y en el último análisis debemos considerar que la investigación y el desarrollo son actividades que van a catalizar el proceso de crecimiento industrial y económico. H.C. Douglas, Asesor de Pesquisa Industrial, Departamento de Industrias, Ottawa em 1967 (Sunkel, 1970, p. 77).

A simples transferência tecnológica que tanto preocupava a Sánchez é precisamente a base desse problema. No caso mais técnico, dado que a translação da tecnologia criada no Centro, ao não ser criada nem para as condições, nem pelas condições de determinada situação, não contribuía com a ampliação da sua densidade científica e tecnológica que é o embasamento do seu bem-estar. Isso gerava atraso, heterogeneidade e assimetria tecnológica, tudo isso, se lembramos o caso daquela intervenção francesa na comunidade mexicana que expõe Sánchez -capitulo 2-, garantias do modelo de dependência da região com o Centro e significantes da desigualdade social. Já mencionei que a crítica e as preocupações de Vicente Sánchez, recolhiam vários anos de inquietações e discussões sobre o assunto. Em 1967, a primeira reunião do Grupo de Especialistas em Ciência e Tecnologia do Conselho Interamericano Cultural, já tinha expressado precisamente aquela cadeia lógica; repito: em $1967 .{ }^{17}$

Os argumentos gravitavam em torno da ideia de que nem a geração do conhecimento nem da tecnologia correspondiam à matriz cultural das circunstâncias como base fundamental do subdesenvolvimento.

\section{'Povocentrismo'}

1.

Em uma linha mais crítica, o argentino Óscar Varsavsky realçou as características dessa distorção como causa fundamental do estado social da América Latina. Ao se abandonar a ideia de que as produções devem se embasar nas circunstâncias pelas circunstâncias, na prática latino-americana se garantia que nunca se fortaleceria nem a

\footnotetext{
17 Aquele Grupo pertencia ao Programa Regional de Desenvolvimento Cientifico e Tecnológico da Organização de Estados Americanos, OEA.
} 
criatividade popular, nem a solidariedade social, assim como tampouco a sua participação -vários dos transcendentais defendidos por Sánchez para o desenvolvimento sustentável-. Pelo contrário, sendo espelho do Centro, estava-se eliminando a possibilidade de superação da miséria e da pobreza (Roldán, 2010).

Já mencionei como para intelectuais como Varsavsky esse subdesenvolvimento na região bebia de várias fontes, uma delas era a que ele chamava de 'cientificismo': uma postura que fazia com que as nossas sociedades olhassem romântica e acriticamente para o Norte -EUA e Europa- superestimando o que nesses locais fosse afirmado, e principalmente 'comprando' as hipóteses que eram produzidas nesses locais com a ironia da ilusão de liberdade investigativa

[...] ¿Qué puede tener esto de objetable? Es un tipo de dependencia cultural que la mayoría acepta con orgullo, creyendo incluso que así está por encima de 'mezquinos nacionalismos' [...] ni siquiera tiene sentido, se dice, plantear la independencia con respecto a algo que tiene validez universal, más fácil es que los católicos renieguen de Roma. Oscar Varsavsky (Argentina) em 1969 (Galafassi, 2004, p. 2).

Uma cadeia causal que explicava a dependência. Um modelo que perpetuava o local da América Latina no cenário internacional. Entre outras coisas, a ciência desse tipo de sem-saídas fez com que fosse procurado o princípio da mudança na mais variada gama de intelectuais da região. As elucubrações de Varsavsky o levam a afirmar que no fundo de tudo, naquele esquema repousava uma política científica nacional alinhada com os interesses do capital estrangeiro. Um sistema funcional e fiel cópia do sistema social de consumo. Uma estrutura na qual a criatividade era perdida gradualmente e com ela -"se desmanchando no ar"- a possibilidade de conquistar ideias novas e socialmente renovadoras.

Nessa encruzilhada, parecia haver uma saída só. No maniqueísmo próprio da época, ou se intensificava o sistema reinante, ou se visualizavam novos horizontes produtivos. Para ele, como para tantos outros no momento, tanto a ciência quanto a tecnologia deviam responder às necessidades sociais que cada contexto exigia... deviam ser circunstanciais. Altamente político, Varsavsky parecia olhar com reserva a epistemologia dedutiva, que pretendia explicar os fenômenos a partir da teoria. Para ele, a mudança social só era possível com base em um sistema tecnológico que respondesse ao que ele chamava de "estilo de desenvolvimento". Um esquema ditado pelas condições de cada realidade, com o seu próprio estilo tecnológico e científico. Uma aposta que 
compreendia os requerimentos 'do povo' e não das empresas, como a razão de ser da existência do desenvolvimento... o caminho para uma prática cientifico-tecnológica autônoma, livre do "cientificismo".

\section{2.}

Sunkel não é tão radical como parece ser Varsavsky. Ele representa uma linha crítica mais progressista. Poderia especular que Varsavsky fazia parte de uma facção de intelectuais latino-americanos que defendia uma postura heterodoxa de base comunista, quem sabe, na linha crítica que representou André Gunder Frank -que explorarei à frente-. Contudo junto com Sunkel -inclusive com Sánchez- compartem tanto um enfoque relativamente maniqueísta, como claramente uma postura circunstancial da criação do conhecimento. No contraste dos diagnósticos, os três concordam em decidir se os esforços pela conquista do bem-estar devem ser feitos na manutenção de um modelo que representa tantos males para a região ou no estabelecimento de uma nova plataforma. Obviamente a formulação já incorporava a resolução do dilema. ${ }^{18}$

Para Sunkel, o desenvolvimento autônomo estava estreitamente ligado a uma nova estrutura produtiva. Era importante -de fato era imprescindível- que as sociedades subdesenvolvidas conseguissem estabelecer uma estrutura científica e tecnológica moderna... diria eu, que fora própria e densa. Aquela estrutura devia ser capaz de se relacionar com a tecnologia da seguinte forma: se ela era estrangeira, por meio de um apreço, adaptação ou até uma transferência crítica... tudo isso feito se ela não fosse criada no contexto, que era o melhor dos casos.

Essa espécie de bifurcação me lembra duas coisas que gostaria associar aqui antes de seguir. A primeira tem a ver com o documento de Vicente Sánchez que já mencionei (Sánchez, 1978). Lembrarei rapidamente que em meio às suas preocupações com os problemas da tecnologia adequada, ele propunha um certo protocolo para a intervenção em populações carentes. Grosso modo, aquele protocolo deixava ver que no caso em que a carência que padece o grupo não possa ser resolvida com a infraestrutura disponível

\footnotetext{
18 É sintomático como essa mesma fórmula também é usada nos argumentos dos latino-americanos que defendem a criação da ALADI em Bogotá. Só para ilustra-lo, gostaria trazer o trecho com o qual se identifica o Grupo de Desenho Industrial da Fundação de Tecnologia Industrial, do Ministério de Industria e Comercio brasileiro em 1979 "partindo do fato de que a tecnologia é fundamental ao desenvolvimento de qualquer país, o que deve fazer um país periférico para alcançar o domínio tecnológico? Conforma-se com as dificuldades de produção de tecnologia [...] limitando-se a ser um importador e copiador, ou buscar soluções próprias, com os meios ao seu alcance (que nem sempre são muitos) e utilizando o seu potencial enquanto país, a herança cultural da sua comunidade e a criatividade de sua população" (INT, 1979, p. 1).
} 
no contexto -o que deveria se esgotar rigorosamente, inclusive em baixo de formas de resolução primitivas- era importante avaliar com todo cuidado e incisiva crítica a introdução de novos elementos nesses contextos. Era preciso defender até as últimas consequências o que ele denominou de "criação endógena".

A segunda foi a aproximação que conseguiu a equipe brasileira em 1979 ao determinar as relações que deveriam ser estabelecidas entre o design e as políticas nacionais de produção. 0 documento que registrou esse debate, foi entregue pela delegação desse país no congresso inaugural da ALADI em 1980. Só para lembrar, nessa aproximação os brasileiros estabeleceram que o design tinha a tarefas de criar a "tecnologia industrial endógena" -o termo é exatamente esse-, assim como controlar tanto a importação, quanto a integração de tecnologias importadas "indispensáveis ao nosso desenvolvimento" (APDINS-RJ, APDINS-PE, \& ABDI, 1979a, p. 7).

Vejo como a ideia exposta por Sunkel -da qual ele é representante aqui nessa parte do meu texto- ${ }^{19}$ foi expressada, ainda afinada e até complexificada por Vicente Sánchez no documento que redigiu em 1978 e que a organização do Interdesign mexicano usou. É relativamente esperado. Ao que parece, existe uma nítida linha que liga a Sánchez com Sunkel. 0 primeiro foi diretor do escritório latino-americano do PNUMA -Programa das Nações Unidas para o Meio Ambiente-; Sunkel foi fundador e primeiro diretor da Unidade de Desenvolvimento e Meio Ambiente CEPAL/PNUMA em 1978.20

Por sua vez, o uso do sentido e da estrutura desse argumento pelos brasileiros envolvidos no processo de conceituação do design em 1979 sem referência bibliográfica, mostra como o esquema retórico dessa linha crítica tinha sido incorporado nos sentidos comuns, nesse caso pontual, de um grupo de brasileiros reunidos nove anos depois de publicado o artigo de Sunkel. Sei que esse documento brasileiro foi antecedido por outros que foram construídos de forma gradual. Mas realço que aquele documento de Sunkel, também fazia parte de uma linha argumental que facilmente podia se remontar

\footnotetext{
19 Essa ideia vinha sendo debatida nos cenários da crítica econômica e social da região e de vários intelectuais preocupados com os problemas do desenvolvimento e o capitalismo desde os anos 1950.

${ }^{20}$ Além disso, o trânsito de ideias entre escritórios da ONU parece ter sido realmente intenso naqueles anos a esse respeito. Aquelas teses defendidas na CEPAL, eram debatidas no interior do PNUD, da UNESCO, inclusive da OIT assim como as teses levantadas no PNUMA chegavam tanto a uma, outra e a outra e vice versa. Tal circuito de teses e apostas conceituais podem explicar a proximidade de corpos associativos de designers com alguns desses órgãos durante os anos sessentas e setentas, assim como o interesse da ALADI de ser reconhecida como entidade especializada de consulta de ECOSOC -Conselho Econômico e Social das Nações Unidas-. Eram instituições revestidas de credibilidade. Da mesma forma, em um sentido mais anedótico não por isso menos importante, tanto Sunkel como Sánchez são chilenos.
} 
às primeiras críticas do argentino Raúl Prebisch na fundação mesma da CEPAL em 1948. Ideias às quais voltarei daqui a pouco.

Claro, não afirmo que o documento de Sunkel orientasse as reflexões desse grupo de brasileiros. Por uma parte, assim eles tivessem tido contato com ele -o qual ignoro-, o texto não chegava puro para ser vertido num recipiente vazio. 0 que tento expor é que esse texto de Sunkel demostra a circulação dessas ideias desde um órgão institucional de determinado nível de influência nas sociedades latino-americanas, tanto nos seus governos, como nas suas camadas de acadêmicos e intelectuais. 0 fato de que aqueles cariocas tivessem defendido essa tese dessa maneira, vincula Sunkel a eles por meio do trânsito de ideias. 0 fato de que o conteúdo e a forma seja apropriado nesse discurso carioca -somado à ausência de referência- exibe o nível de inconsciência em que já circulavam essas teses pelo Rio de Janeiro. 0 fato de que fosse mencionado na maioria da documentação apresentada pelas delegações nacionais presentes em Bogotá em 1980 guardando o seu núcleo, demostra a intensidade da ideia, a multiplicidade de fontes por onde ela se movimentava e as suas maneiras de apropriação.

3.

Parece-me interessante retomar que na fórmula que consentia Sunkel para o desenvolvimento autônomo, aquela geração era compreendida como o elemento que permitiria reverter o sentido da dependência. 0 ato criativo era visto como o caminho para a geração, que se compreendia como inovação e tecnologia. A nova estrutura, que estava conceituando Sunkel, suponha que a autonomia, ou pelo menos a quebra com a dependência com o Centro, permitiria que criar na América Latina por sua vez permitisse exportar bens manufaturados, penetrar mercados externos diversos, resistir criticamente àquilo que chegasse de fora e, como o grande epicentro -de fato é o primeiro elemento que ele lista- promover um desenvolvimento tecnológico apropriado para as nossas necessidades... um estilo de desenvolvimento 'povocêntrico', como dizia Varsavsky.

É sintomático que essas possibilidades tenham sido parte de políticas públicas em vários países desde esse momento e durante os anos seguintes. Tanto a Argentina, quanto o Brasil, a Colômbia e o México pelo menos, implementaram projetos que estimulavam a exportação de bens manufaturados que procuravam a penetração de mercados diversos. Claro que a qualidade dessa aposta respondeu à própria realidade 
de cada país. Mas, poderia afirmar que em todos eles, promoveu um processo de institucionalização do design, em geral, puxado pelas condições que gerava a aplicação dessas políticas nos respectivos governos. ${ }^{21}$

Geração compreendida como o princípio que permite que os objetos que satisfazem as necessidades sejam produzidos no sentido em que as condições exige. A ilusão de bem-estar se explicado a partir desse enfoque. Por uma parte, a ampliação da base tecnológica regional que prometia tirar a América Latina do seu papel de consumidor da tecnologia importada desde o Centro. Com ela, a resolução das variadas necessidades e carências que afligiam esse território exótico... a resolução da miséria e da pobreza que tanto tresnoitou uma cumprida linha de intelectuais latino-americanos?

Não posso desenhar a linha entre esse texto de Sunkel e a equipe da ALADI, pelo menos não desde uma expectativa positivista. Frente ao documento completo, como desse trecho em particular, não parece tão descabido pensar em que o pensamento de Sunkel estava presente na assembleia inaugural da ALADI em Bogotá. No final, de novo, tanto o conteúdo como a forma do argumento estão aí para ser comparados.

210 trânsito de designers especialistas naqueles temas eclode naqueles anos também. Isso explica, por exemplo tanto a chegada de Gui Bonsiepe à Argentina, quanto a sua mudança para o Chile e logo depois ao Brasil. 


\section{Industrialização como desejo}

[...] No jogo econômico, sempre houve cartas melhores do que outras e às vezes, muitas vezes, marcadas. Certas atividades dão mais lucro do que outras [...] mais lucrativo trabalhar no setor secundário do que no primário, no setor terciário do que no secundário. Se as trocas entre Inglaterra e Portugal, no tempo de Ricardo [1817], caracterizam-se por aquela fornecer tecidos e outros produtos industriais e este fornecer vinho, Portugal encontra-se no setor primário, em posição de inferioridade (Braudel, 1998, pp. 37-38).

\section{A disciplina das práticas}

1.

Como tenho exposto até o momento, satisfazer as necessidades da população, nas condições em que elas se apresentavam, supunha o fortalecimento social para os fundadores da ALADI. Aliás, a oportunidade para fazê-lo com a chamada 'capacidade instalada' e os meios tecnológicos locais, supunha também a possibilidade de obter o desenvolvimento econômico. Uma via clara para a autonomia. Tanto o robustecimento social, quanto o econômico, permitiriam a conquista de um melhor nível de vida para a população, assim como a fortificação da região na frente da chamada "Divisão Internacional do Trabalho". Nesse esquema, a América Latina cumpria o papel de provedor de matérias primas, endossando a estabilidade da sua balança de pagamentos nas flutuações do desenvolvimento das economias industrializadas e desenvolvidas e se expondo à "vulnerabilidade econômica".

Como falei em páginas anteriores, a ideia da tecnologia como suporte para a conquista desses preceitos, percorreu o imaginário e os planos dos mais diversos intelectuais e políticos latino-americanos, durante as décadas meridionais do século 20. Uma ideia onde o processo de industrialização era concebido como o único caminho possível para suavizar a dependência econômica com os países já desenvolvidos. A estrutura básica desse ideário foi formalmente conceituada na América Latina durante a década dos anos 1940, a partir das condições avaliadas pela experiência e o contato direto com a realidade, e não como uma imposição teórica acima dessa realidade. 
Tanto a experiência como a elaboração teórica correspondem a Raúl Prebisch, economista argentino quem embebido em um claro circunstancialismo, procura a autonomia econômica da região como mecanismo para conseguir o desenvolvimento, primeiro do seu país -final dos anos 1920- e logo depois da América Latina. Os seus postulados deram estrutura à criação da CEPAL, escritório das Nações Unidas que ele mesmo orientou entre 1950 e 1963. Talvez o exercício conceitual mais conhecido de Prebisch seja a oposição conceitual Centro-Periferia, exposto formalmente em 1944 e trabalhado por Prebisch desde décadas anteriores. A ideia percorreu e dialogou com intelectuais ao redor do mundo.

2.

A teoria da vantagem comparativa, proposta por David Ricardo no século 19 e reelaborada acima dos princípios de -entre outros- Jhon Stuart Mill e Alfred Marshall nas últimas décadas desse século, parecem ter-se misturado no Ocidente com o crescimento econômico embasado nas exportações, como promessa para a conquista de um desenvolvimento sustentado e um bem-estar possível.

A prática desse modelo econômico pressuponha uma relativa igualdade entre países dado o cálculo de que cada um dos países envolvidos exportaria aquilo que era abundante na sua realidade; a hipótese de que o comércio internacional eliminaria o poder monopolístico, assim como garantiria a disseminação dos benefícios do progresso tecnológico; a ideia -seguramente mais promissora- de que esse comércio reduziria as diferenças entre salários, rendas, e outros fatores relativos à produção no sistema mundial de comercio. Contudo, o modelo foi justificando tanto o caráter quanto o lugar dos diferentes atores econômicos naquilo que foi denominado como "Divisão Internacional do Trabalho".

Nesse panorama, o lugar que ocupava a região era um lugar de provedora de bens do setor primário, denominadas nessa época como produtos das industrias naturais. Assim, seguindo o cálculo, os países da América Latina exportavam aquilo que abundava no seus territórios, enquanto os países industrializados -como nesse momento principalmente a Inglaterra- produziam mercadorias que nossos países compravam. Boa parte das elites políticas latino-americanas sentiam-se relativamente confortáveis ocupando esse sítio. Mas a complexidade das relações econômicas e sociais com que vão 
se caracterizar os primeiros trinta anos do século 20, exporia as dificuldades para a região.

Durante esses anos, vários empreendimentos industriais tiveram lugar em vários países da América Latina. Algumas empresas configuram-se a partir da iniciativa de indivíduos interessados mais ou menos isolados, consolidando uma experiência diferenciada da prática corrente da época. Em um certo sentido, aquela iniciativa para o porvir começaria a ser defendida por eles mesmos e por alguns porta-vozes dos governos. Com proporções diferenciadas, em vários países da região se estabeleceu um confronto entre os dois tipos de industrias: as naturais e as denominadas pejorativamente como indústrias artificiais. Nesse debate pode se explicar a necessidade por uma 'teoria' que permitisse abalar o esforço industrial.

Um caso exposto por Joseph Love (2011) pode ilustrá-lo. No fato da experiência de industrialização, alguns empresários paulistas -gentilício dos habitantes de São Paulo no Brasil- encontraram-se com uma teoria que fornecia os argumentos de base científica a favor da industrialização dos países agroexportadores: o trabalho do economista romeno Mihail Manoilescu. As suas ideias se apresentavam como uma estrutura argumental que, indo além do simples complemento, praticamente exigiam a industrialização como uma plataforma para se opor ao modelo de Divisão Internacional do Trabalho.

Segundo Love, Manoilescu expõe durante os anos 1920, como a produtividade dos trabalhadores de países agroexportadores já era inferior à de seus pares nas economias industriais, exibindo claramente o fracasso do modelo para os países não desenvolvidos. Ao descolorir as premissas previstas do esquema -sobretudo a falida hipótese da disseminação tecnológica e dos seus benefícios econômicos e sociais-, Manoilescu mostrava como os argumentos do modelo neoclássico sobre a divisão internacional do trabalho eram, em realidade, justificativas para que um povo explorasse outro. Nesse caminho, um agravante: o processo estava reunindo em uma mão algumas sociedades caracterizadas pelo avanço tecnológico, econômico e social, e na outra sociedades cada vez mais atrasadas, cuja conquista do bem-estar ficava cada vez mais comprometida -de fato exibidas como sociedades em processo de empobrecimento-. Sendo esta uma região em que várias das suas camadas de intelectuais tinham se proposto, desde o século 19 , à superação da pobreza e à miséria como prioridade antes da conquista de 
outros ideais sociais (Cancelli, 2003), esse cenário se apresentava como uma obstrução irremediável que encorajava as ideias de mudança social.

\section{3.}

Os argumentos apresentados pelo trabalho de Manoilescu, ainda já perceptíveis na realidade de várias economias da América Latina, não eram exatamente visíveis. De fato, prévio à depressão de 1929, o modelo agroexportador mostrava relativos sucessos, por exemplo na Argentina ou na Bolívia. ${ }^{22}$ De certo modo, teve de se dar o desabastecimento por causa da depressão e da guerra, assim como o aumento dos preços das mercadorias para que o desequilíbrio da balança de pagamentos se tornasse uma realidade na América Latina, evidenciando cruamente a vulnerabilidade econômica das nossas sociedades.

Agora, o fato de não terem sido elementos estritamente visíveis em determinado momento, não significa que não estivessem já instalados nos raciocínios e nas preocupações dos diferentes intelectuais latino-americanos, sobretudo aqueles que vinham observando e administrando a economia dos seus países. Um deles será o equatoriano Victor Estrada que mostrou problemas relacionados com uma troca em detrimento desde 1922. Outro, o economista argentino Raúl Prebisch. Para eles as diferentes situações vividas enquanto funcionários de alto nível do seu respectivo governo, permitiu-lhes compreender as dimensões concretas da junção entre as economias industrializadas e as subdesenvolvidas relativas a esses processos de troca.

Palavras a mais, palavras a menos, as preocupações gravitavam em torno do impacto das variações econômicas que eram próprias ao capitalismo. Quando os índices de crescimento subiam, tanto as economias industrializadas quanto as agrárias cresciam de formas mais ou menos similares. Mas quando o sistema vivia uma queda, a grande maioria dos impactos eram conduzidos para as economias agrárias. A ironia expressa por Braudel pode ilustrá-lo: “a troca externa tende para o equilíbrio recíproco e não pode deixar de ser lucrativa para os dois parceiros (na pior das hipóteses, mais para um do que para outro)" (Braudel, 1998, p. 37). Isso foi percebido por Prebisch -entre outras

\footnotetext{
22 Roberto Cortés (1992, p. 30) apresenta a relação do comercio exterior argentino entre 1879 e 1914 , deixando ver que naqueles 45 anos, um pouco mais do que a metade das vezes a balança argentina foi positiva -no 60\% das vezes, principalmente entre 1889 e 1914-. No caso boliviano Herbert Klein (1992, p. 220) deixa ver que entre 1895 e 1930, o país andino só apresenta índice negativo na sua balança em 1921. Positivo significa que foi mais o exportado que o importado, ficando um saldo para o país.
} 
experiências- nas relações que a Argentina mantinha com a Inglaterra em torno do comércio da carne.

Aquela vulnerabilidade não poderia ser superada se comportando da mesma forma no sistema internacional de comércio. A industrialização não podia mais ser vista como um esforço de alguns interessados. Devia virar política de Estado. Já não um fato, mas um desejo, como problematiza Love (2011).

4.

Antes de avançar no argumento, pode ser didático trazer algumas ideias daquilo que venho realçando como 'o espírito latino-americano' durante o percurso do texto. Um sistema de relação com a realidade que parece mostrar algumas qualidades. Uma delas tem a ver com a constante de vários intelectuais latino-americanos em pegar ideias ou teorias de diversos contextos e construir uma mirada da realidade a partir da sua reelaboração. Uma antropofagia, como defendeu Oswald de Andrade em 1928. Poderia dizer, a construção de uma epistemologia que parte do estabelecimento de um diálogo entre uma aproximação empírica da realidade e uma interpretação dedutiva dela.

Agora, essa antropofagia pode ter incluído uma outra caraterística: um latente circunstancialismo. A partir do fato de perceber e refletir a experiência por meio da realidade, se dava lugar a um diálogo interno -de motivações essencialistas-, sugerindo que cada condição apresentasse as suas próprias particularidades, as que exigem entendê-las na suas respectivas complexidades, sem generalizações ou imposições trazidas de fora do problema. As coisas deveriam se compreender no seu contexto -na circunstância- e daí, procurar as dimensões de tentativas da sua solução. Um relativo esforço de preservar a autonomia respira no âmago desse princípio. É mais ou menos claro que defender o circunstancialismo é defender o fato de que a realidade que eu vivo é diferente da sua. Daí que eu deva fazer o exercício de compreendê-la e resolvê-la.

Essa digressão pode ser ilustrativa ao observar que a mais diversa gama de produtos modernos em várias partes da América Latina podem ser explicadas por esse diálogo. Com os diferentes níveis, gradações e proporções, desde as experimentações nas artes visuais, a literatura, a arquitetura, o design, talvez a música, até as formas como eram levantados diagnósticos sociais e econômicos. Um dos casos pode ser a própria experiência de Prebisch. 
5.

Fechando o parêntese, o sistema internacional de comércio foi mostrando as suas fissuras e fracassos no caso latino-americano. Nesse contexto, os diversos problemas vistos por Prebisch o levaram a procurar levantamentos conceituais que explicassem o fenômeno "[um] cuerpo analítico que deriva de un fértil cruce entre un método escencialmente histórico e inductivo, por un lado, y una referencia abstracto teórica propia [...] por el otro" (Bielschowsky, 1998, p. 1). ${ }^{23}$ Segundo Love (2011), Prebisch começou a formular uma teoria sobre a troca desigual em 1937 o que o levou a postular aquela que será uma das suas maiores contribuições à teoria econômica: a oposição Centro - Periferia.

As diferentes pesquisas de Love, lhe permitiram afirmar que a primeira vez que Prebisch falou dessa oposição, foi em uma série de palestras na Universidade de Buenos Aires na Argentina. Segundo Love, a partir do registro no caderno de um assistente naquelas palestras, a formulação ocorreu em 1944. O contexto era o problema da estabilidade monetária do sistema mundo, a custa da recessão na Periferia.

A proposta tem a uma importante grade didática como marca Ricardo Bielschowsky (1998). Ou seja, a estratégia do contraste entre 'eles e nós' -maniqueísta e essencialista-, entre outras coisas permitiu ver a região como periferia mostrando-a como uma realidade diferenciada, com as suas próprias carências, o seu próprio processo e o seu próprio ritmo de modernização. Um modo singular de industrializar, uma peculiar forma de absorver a força de trabalho e de distribuição do ingresso, assim como uma forma particular de introduzir o desenvolvimento técnico, o crescimento e o progresso, assim como contribuiu para fazer consciência de todos esses atributos desde a crítica econômica. Mostrou a região como uma região essencialmente distinta, em uma circunstância particular que justificava a particularidade e defendia a sua autonomia... uma autonomia cuidada na região desde o século 19.

Sublinhando tais ideias sobre a região, a teoria Centro-Periferia também chegava como uma teoria própria. Um aparato conceitual que vinha sendo construindo indutivamente, a partir da experiência de intelectuais da região com a realidade da região durante uns trinta anos. As preocupações do equatoriano Victor Estrada datam

\footnotetext{
23 Bielschowsky formula esse enunciado oferecendo uma explicação à ausência de referências para a CEPAL, no conjunto de contribuições à teoria econômica mundial. 0 uso aqui, dado que falar de Prebisch é quase falar da primeira parte da CEPAL.
} 
de 1922 e elas já eram um esforço por conceituar um fenômeno de pelo menos uma década.

Segundo a trajetória desenhada por Love, a ideia Centro-Periferia foi escrita por primeira vez em 1946 por Prebisch, dois anos depois de apresentadas nos seminários da UBA. O contexto foi o "segundo encontro dos diretores dos bancos centrais do hemisfério" (Love, 2011, p. 183), onde, também apresenta os Estados Unidos como Centro -já nesse momento tendo substituindo à Grã-Bretanha- e a América Latina como Periferia.

Nas leituras feitas por economistas da época, a Grã-Bretanha como Centro tinha algumas vantagens se comparada com os Estados Unidos. Os ingleses sacrificaram o seu território, apostando na industrialização, o que fazia com que dependessem da Periferia para o seu abastecimento de matérias primas. No seu caso, os Estados Unidos eram possuidores de enormes extensões de terra, fazendo deles uma economia relativamente auto abastecida. No sistema de troca, isso representava menos compra por parte deles, significando menos venda por parte da América Latina. Em síntese uma pinça que se fechava: de um lado, o bloqueio do crescimento e estancamento do progresso, por outra, o consequente aprofundamento da pobreza e da miséria.

o Centro possuía uma estrutura diversificada -produção de muitos tipos de produtos-, com sistemas de produção homogêneos -incentivos do desenvolvimento tecnológico- e criava e difundia tecnologia transmitindo os seus frutos.

De sua parte, a Periferia tinha uma estrutura pouco diversificada -quase dependia do mesmo tipo de produtos todo tempo-, com sistemas de produção heterogêneos, onde poderiam se encontrar 'tecnologias de ponta' 'recém chegadas' do Centro -ao se projetar em um outro contexto, ofereciam outra quantidade de problemas que mais a frente seriam criticados- misturadas com as mais diversas técnicas tradicionais e artesanais. Não havia criação tecnológica -no esperado sentido capitalista- e, por tanto, não existia a sua difusão. Os frutos eram calculados da transferência tecnológica importada que, ao serem redutos e patentes obsoletas no Centro, não chegavam nem mesmo a ser transmissões paternalistas das suas obsolescências. 


\section{O progresso técnico como caminho para a prosperidade}

[...] O "estruturalismo", ligado à Comissão Econômica para América Latina (CEPAL), e, subsequentemente a "teoria da dependência" foram contribuições à teoria do desenvolvimento tipicamente autóctones, distintamente latino-americanas (Love, 2011, p. 161).

1.

O desabastecimento de mercadorias sofrido na região durante a Segunda Guerra Mundial já tinha obrigado que os processos de industrialização começassem em alguns países da região. Eram processos que se caracterizavam pela substituição daqueles produtos que eram importados dos países industrializados antes da guerra e que, de certa forma, como prática, precisavam se disciplinar teoricamente

[...] Raúl Prebisch y Hans Singer, en 1950, [no interior da CEPAL] construyeron un modelo cuya idea central era que la especialización en bienes primários, por su limitado progreso tecnológico, y la tendencia decreciente de los términos de intercambio, imposibilitaban el proceso de industrialización de las economias y acrecientan su vulnerabilidad respecto a los choques externos. Los países latino-americanos y caribeños podían obtener las ventajas del avance tecnológico sólo por la industrialización (Puyana et al., 2008, p. 164).

Daí que, a partir da compreensão da América Latina na sua própria realidade -toda uma reivindicação circunstancialista-, a primeira bandeira da CEPAL fosse visualizar e formular as estratégias que estimulassem e protegessem a industrialização latinoamericana. Por causa disso, a fórmula foi a conceituação dessa prática, resumida na famosa sigla ISI: Industrialização por Substituição de Importações.

Segundo as linhas marcadas pela CEPAL, era necessário que de forma gradual se fossem substituindo as mercadorias que as economias latino-americanas compravam no mercado internacional. A receita predeterminou uma progressão entre duas etapas escalonadas que adensaram progressivamente o processo de industrialização. A primeira chamada ISI fácil, que tinha a ver com a substituição dos bens de consumo simples. A segunda, relacionada com a produção de bens intermediários e produtos de consumo duráveis. Assim, passando de uma a outra, se mudava de uma fase horizontal a uma fase vertical da ISI "de produtos simples numa frente ampla e, na segunda, uma linha integrada de produção de uns poucos produtos finais e seus insumos" (Love, 2011, p. 204). Superar a primeira fase para chegar na segunda, era se preparar para o desejado 
terceiro momento: a produção dos bens de capital... uma tentativa de plena industrialização.

2.

Dentre as contribuições da primeira fase da CEPAL -coincidente com os seus primeiros 12 anos, entre 1948 e 1960- podem se contar as análises de elementos problemáticos para o desenvolvimento da região. A CEPAL também trabalhou naqueles anos pela integração e o estabelecimento dos seus mecanismos, como a conformação do BID -Banco Interamericano de Desarrollo-, ao considerar que a criação de mercados regionais, estimularia a industrialização.

Mas a consciência do papel do Estado na fórmula do desenvolvimento, assim como o evidente circunstancialismo e autonomia para definir as estratégias econômicas relacionadas com a realidade da região, eram com claridade os seus grandes apoios conceituais. Era preciso que o Estado protegesse o início da industrialização evitando a derrota do processo no seu início. E o fato de que as prioridades gravitaram em torno desse propósito, partia da ideia de que a natureza do processo de industrialização latino-americano devia ser particular, dadas as particularidades que apresentava como região.

Para Bielschowsy (1998), só as ideias relativas à reforma agrária poderiam acompanhar às relacionadas com o progresso técnico como esse eixo fundacional e produtivo da CEPAL. Tanto uma quanto a outra, grandes aglutinadoras do pensamento progressista na região, quase sem importar o extrato ideológico. As primeiras -reforma agrária- como condição para a distribuição da renda; as segundas -progresso técnicocomo caminhos para eliminar a vulnerabilidade externa e garantir a saída da pobreza.

Assim apareciam elas como se fossem atualizadas as antigas expectativas sobre as nações latino-americanas, que tinham sido construídas pelos diversos grupos de intelectuais da região: desenvolvimento técnico, autonomia, circunstancialismo, essencialismo, superação da pobreza e da miséria. ${ }^{24}$ Reeditados, esses princípios vão circular pelo continente, eclodindo desde Santiago de Chile enquanto dialogam com as mais diversas camadas de latino-americanos, sobretudo com os jovens estudantes. E

\footnotetext{
${ }^{24}$ Aparecer é uma figura. A verdade essas preocupações nunca deixaram de estar nos raciocínios dos diferentes intelectuais da região. Elas podem se encontrar nos discursos desde o próprio século 18. A significação se atualiza em cada momento, mas a preocupação parece latente e constante.
} 
circulavam em meio à sociedade filtrados por diversos mecanismos de difusão. Estabelecendo-se como escola e oferecendo aqueles temas pelas reflexões, a CEPAL gerou uma agenda de ideias para os diversos interessados da e na região e com certeza contribuiu com a ideia de um pensamento latino-americano de largo alento. 25

0 otimismo com o ISI, assim como o registro de alguns indicadores de crescimento de alguns países da região alcançou tais níveis, que em meados da década de 1950, a CEPAL chegou a relativizar o papel das relações de dependência que a região tinha estabelecido historicamente com o Centro. Alicia Puyana (2008, p. 81) apresenta uma tabela das médias de crescimento anual da indústria na região dividida por décadas, onde é notória a curva ascendente que marca o crescimento industrial na América Latina, marcando entre 1,5\% em 1950 e 7,0\% em 1960.

O maior otimismo vinha do comportamento 'exemplar' do desempenho argentino, que para 1957 era considerado como o país mais industrializado da região: "a CEPAL parecia perguntar alto e bom som se a experiência argentina não seria o futuro da América Latina" (Love, 2011, p. 205). A isso se somou o relativo sucesso da estratégia ISI tanto no Brasil -abertamente reconhecedor da origem cepalina das suas políticas desenvolvimentistas dos anos 1950- quanto no México.

\section{Teoria da Dependência e diálogo com a esquerda-nacionalista}

1.

$\mathrm{Na}$ segunda metade dos anos 1950, surgiram ideias contraditórias sobre o processo de crescimento dos países da região. Certamente, existia um otimismo a partir dos indicadores de alguns processos de industrialização. Porém, com eles também tinham aparecido críticas mais profundas que deixavam ver que aquele otimismo poderia ser um tanto ilusório. Essas críticas partiam em grande parte da própria CEPAL. Nesse momento, se criava consciência de um certo desgaste do proposto no escritório desde 1949.

Os indicadores mostravam como a industrialização não estava acompanhando as taxas de crescimento populacional que eram impulsionadas pelos processos de

\footnotetext{
250 que parece sensato afirmar é que se somou às correntes já formuladas na região, retomando várias linhas que vinham do passado, recriando e criando mais outras. 0 que também parece justo é reconhecer que dada a institucionalidade que ela representa -um órgão consultor da ONU- a força do que diagnosticava e propunha, conseguia penetrar nos mais diversos cenários políticos desses anos.
} 
urbanização, resultando na exclusão da maioria das pessoas da modernidade e do progresso

[...] Entre 1940 y 1960 el porcentaje de latinoamericanos que vivía en zonas urbanas aumentó del 33\% al 44\%. En 1990 esta proporción había llegado al 72\%. En sólo 50 años América Latina se había transformado de región rural en región urbana [...] durante las décadas de 1950 y 1960 el crecimiento urbano fue muy rápido. En ciertos momentos, ciudades como Bogotá, Caracas y São Paulo casi duplicaban su población cada 10 años (Gilbert, 2008, p. 129).

De igual maneira, também mostrou que a pesar do crescimento industrial, o processo não conseguiu eliminar a temida vulnerabilidade nem a dependência com o Centro. Vários problemas contribuíam com o declínio do ritmo de crescimento para 1964. Em 1959, Prebisch já tinha previsto essa ironia. Era como se a promessa estivesse desmanchando no ar, na frente de todos os que apostaram que América Latina por fim tinha encontrado o seu caminho.

A crítica cepalina do processo assinalou vários elementos que poderiam explicar o desmonte do ISI durante os anos 1960. Entre eles, Love (2011) sublinha o desequilíbrio perpétuo, que fortalecera as interpretações marxistas heterodoxas e revolucionárias daqui a pouco o abordarei-; as tensões sociais promovidas pelos processos atrasados de urbanização -favelização-; as precárias estruturas sindicais possuidoras de autonomia a maioria das existentes tinham sido cooptadas pelos Estados-; as instabilidades políticas que se manifestavam de diferentes formas nos países da região -desde a violência partidarista vivida na Colômbia, até o estabelecimento de ditaduras na maioria de países do Cone Sul-; um patrão agrário fixo, uma estrutura industrial pouco diversificada e de níveis heterogêneos, assim como uma má distribuição da renda, o que somado a uma rígida estrutura social que claramente dificultava a ascensão social, resultava na dificuldade de 'aceder à modernidade' para grandes camadas populacionais. ${ }^{26}$

Nesse momento, o cenário político e social no qual se davam essas leituras contribuía igualmente com a tensão e batia no reformismo planejado. 0 desenvolvimentismo brasileiro parecia chegar ao fim com o estabelecimento do regime

\footnotetext{
26 Um caso extremo como exemplo. Gilbert (2008, p. 146) expõe indicadores desagregados por serviço público em vários países da região. No caso do fornecimento de agua em 1960, mostra como na Colômbia -o de maior cobertura dos países apresentados- o $79 \%$ da população tinha acesso ao liquido. Chile é segundo com 74\%, seguido do México com 68\%, Argentina 65\%, Venezuela 60\%, Brasil 55\%. 0 Peru fecha a lista com 47\%. Gilbert toma as informações das Nações Unidas e do Banco Mundial.
} 
militar em 1964, autoritarismo e instabilidade política que também aconteceu na Argentina em 1966. Os Estados Unidos invadiram a República Dominicana em 1965 -um eco do ocorrido 11 anos antes na Guatemala-, evidenciando a mudança no olhar do seu governo nos assuntos da região e fortalecendo ainda mais aquele espírito anti-yankee que vinha passando por varias camadas de intelectuais latino-americanos.

O olhar dos EUA sobre a região já tinha mudado quando Lyndon Johnson assumiu o poder após a morte de Kennedy. As dinâmicas expansivas que talvez poderiam caracterizar as políticas norte-americanas a respeito da região, tinham se ajustado por causa da Revolução Cubana em 1959. A formulação do "Corpos de Paz", assim como o ajuste da outrora ICA -International Cooperation Administration- na USAID -United States Agency for International Development-, as duas no governo de Kennedy, podem demonstrar isso. ${ }^{27}$ Com algumas variações, tais fundações pretendiam complementar as ações da agenda internacional norte-americana frente à ameaça da expansão do comunismo na região, enquanto fortalecia seus processos internos de desenvolvimento em plena Guerra Fria. ${ }^{28}$

Outros elementos faziam aumentar o fervor do momento. Acompanhando o triunfo da Revolução em Cuba -que estimulava a ideia da autonomia nas nossas sociedades, principalmente nos jovens estudantes da época-, camadas de intelectuais sentiram-se ainda mais motivados contra os Estados Unidos dada a sua intervenção no Vietnã, episódios como os de Bahia Cochinos, ou a crise dos misseis em 1962. Mas também com o envio de técnicos em educação como Rudolf Atcon também em 1962, que, entre outras coisas, terminou assinalando que boa parte do subdesenvolvimento das universidades latino-americanas tinha a ver com a participação política dos estudantes e os lugares que ocupava na respectiva instituição: "una representación de esa naturaleza [dos estudantes nos conselhos de direção da universidade], afirmaba [Atcon], era como admitir un espía en el estado mayor del ejército" (Jaramillo, 2007, p. 177).

\footnotetext{
27 Por sua vez ICA parece ser o ajuste da outrora FOA -Foreign Operation Administration-criada em 1953 e abolida em 1955, ano no qual é fundada ICA.

28 "os Corpos de Paz, talvez, a agencia governamental que melhor encarnou a disposição de Kennedy de, a um só tempo, reformular e reafirmar as tradições nacionais [...] os mitos de origem norte-americanos [...] utilizado para motivação da opinião pública interna como justificativa de iniciativas de política externa" (Azevedo, 2008, p. 17).
} 


\section{2.}

É nesse contexto que foram formuladas algumas teorias ao interior da CEPAL, para contestar o estruturalismo do ISI, que, com o passar da década, levou à formulação da famosa Teoria da Dependência, construída entre várias dessas críticas, e atribuída principalmente ao trabalho do brasileiro Fernando Henrique Cardoso e do chileno Enzo Faletto.

Segundo especialistas, a interpretação sociológica de Cardoso e Faletto conseguiu o nível e a precisão graças ao constante diálogo que estabeleceu com os interlocutores da esquerda latino-americana -tanto a heterodoxa, como a ortodoxa e até a revolucionáriatambém preocupada com o processo de desenvolvimento da região. Isso tentarei tratar adiante.

A ideia de que o subdesenvolvimento era uma posição e não um estado a ser superado, exibia uma limitação complicadíssima de ultrapassar tanto quanto uma clara diferença com o que tinha sido pensado nos anos anteriores pela CEPAL. Nesse esquema, defendem que um dos elementos mais problemáticos que promove o subdesenvolvimento na região é a incapacidade das burguesias latino-americanas para liderar o processo do progresso. Ela -a burguesia-, que estaria encarregada de liderar o processo de modernização latino-americano, parecia mais interessada em resolver os seus próprios apetites -com o que consumiam e viviam como se sentindo parte do Primeiro Mundo- deixando passar a necessária oportunidade para investir e renovar o sistema tecnológico, puxando o desenvolvimento, como era esperado. Era uma elite simplesmente arrivista.

Bielschowsky (1998) afirma precisamente que parte da grande iniciativa do trabalho de Cardoso e Faletto foi motivado na contraposição da tese de que as burguesias latino-americanas eram nacionalistas e que estavam comprometidas com o desenvolvimento. Assim como debater a ideia, principalmente defendida por Osvaldo Sunkel, de que a relação entre o Centro e a Periferia se dava em torno do princípio da influência. Cardoso e Faletto falariam de interdependência nos dois lados do sistema, mediados pela presença das multinacionais e com o agravante de que tanto "o setor público, quanto o capital multinacional e o setor capitalista nacional se davam as mãos sob governos autoritários" (Love, 2011, p. 218). Essa fórmula será denominada "desenvolvimento associado-dependente" por Cardoso. 
Considerando a Periferia como uma posição e não uma fase, se compreendia que os problemas da região só seriam superáveis por meio de estratégias que visavam a reforma e a mudança. Essas estratégias claramente priorizavam a transformação política que permitisse o retorno à democracia onde tinha sido assaltada, assim como fortalecida onde os processos se mostravam não formalmente ditatoriais. Insistia em reformar a distribuição de terras, quanto de ingressos -preocupações latentes desde as propostas de 1949-, passando pelas reformas tributárias, financeira, de educação e a reforma tecnológica. A proximidade dessas discussões com as questões debatidas no interior da ALADI parecem cada vez mais claras.

3.

Tanto os problemas e os diagnósticos feitos no interior da CEPAL, quanto as suas propostas estabeleciam -ou pelo menos contribuíam- com uma pauta que estava em discussão nesse momento nas diversas esferas das nossas sociedades: desde os governos e os seus críticos, até a opinião dos cidadãos, passando pelos estudantes. Dessa forma, as ideias de Cardoso e Faletto no seu famoso texto, contribuirão com o debate regional, organizando várias teses. Por exemplo, a ideia de que existe um único sistema Centro-Periferia histórico em evolução; que não existe dualismo mas interdependência ou seja, que não existem simultaneamente um sistema camponês e outro moderno sem relações na América Latina-; que as burguesias latino-americanas já demostraram a sua incapacidade em liderar os processos de modernização regional conforme as necessidades e a particularidade da região, assim como a existência de uma troca desigual como característica do sistema.

Mas aquelas ideias claramente não foram as únicas. Os diálogos entre Cardoso e Faletto -a CEPAL no sentido geral- e André Gunder Frank mostram também outra dimensão do debate. ${ }^{29}$ Concordando com aqueles quatro postulados, Frank diferia com Cardoso na ideia de que na relação entre o Centro do sistema -principalmente Estados Unidos- e a Periferia -América Latina- só existiram trocas desiguais. Para ele, havia uma clara e calculada drenagem do primeiro sob os segundos. Na mesma linha, também afirmava com contundência que o desenvolvimento do Centro tinha sido possível o

\footnotetext{
${ }^{29}$ Gunder Frank foi um economista e sociólogo luxemburguês autonomeado neomarxista radical. Formouse na Universidade de Chicago e morou em vários países da América Latina como o Brasil, o México e o Chile.
} 
tempo todo às custas da Periferia, provavelmente condenando a região a um estado de periferia infinita. ${ }^{30}$

As distâncias de Frank me permitem colocar na mesa a conjuntura do momento, tão ativa como significativa para a configuração do olhar e da crítica dos latinoamericanos da ultima metade do século 20, sobretudo aqueles que nasceram durante os anos 1930 e 1940. A partir dos fenômenos que tinha exposto nessas páginas, e inserido nas batalhas pela autonomia, a busca da identidade e as lutas pela libertação -na fala de Hobsbawm- vários grupos de intelectuais deram novas aproximações nas teorias de Marx

[...] El interés por estos problemas históricos se reavivó de forma espectacular en la década de 1970. En sus orígenes refleja los debates políticos específicos de la izquierda en aquella zona del mundo [Terceiro Mundo], y en particular en la Latinoamerica de las décadas de 1950 y 1960 (Hobsbawm, 2011, p. 360).

Guardando as devidas proporções, a conjuntura parecia uma extensão da política comunista durante a Segunda Guerra Mundial, quando, de Moscou, foi ordenado aos partidos comunistas filiados que apoiassem as burguesias locais no afã de fortalecer os aliados em contra do avanço dos nazistas (Hobsbawm, 1998). ${ }^{31}$ Ao parecer, desde aquele momento a aliança democrático-burguesa ficou 'naturalizada', pois, segundo os relatos de Love, quanto dos de Bielschowsky, o chamado da ortodoxia comunista seguia vigente durante os anos de 1960.

De sua parte, as novas leituras de Marx recuperaram -entre outras coisas- as conceituações dele e de Engels sob os modos de produção, naquela linha que começava no sistema comunal primitivo e que terminaria no sistema socialista. Nessa espécie de processo evolutivo, eles apresentavam a particularidade de um tipo de produção asiático, onde um déspota açambarcava o excedente da produção -salvo uma pequena parte-. Nessa prática, era endossada tanto a inversão, quanto o câmbio e a atualização tecnológica.

\footnotetext{
${ }^{30}$ Em um outro contexto, o próprio Fernand Braudel também estava formulando aquele princípio nesses mesmos anos (1967) "Para uma economia, uma sociedade, uma civilização, ou mesmo um conjunto político, um passado de dependência, uma vez vivido, revela-se difícil de ser rompido [...] 0 passado também tem algo a dizer. A desigualdade do mundo deriva de realidades estruturais, que demoram muito para se instalar -e demoram muito para desaparecer" (Braudel, 1998, pp. 39-40).

31 "os porta-vozes do Partido afirmavam que proletários e burgueses deviam lutar juntos, nessa fase da história, para eliminar esses resíduos feudais e conter a penetração imperialista” (Love, 2011, p. 220). Nesse esquema a burguesia latino-americana era vista como progressista.
} 
Isso estava próximo da denúncia de incapacidade da burguesia latino-americana em liderar o progresso, tanto como dos assinalamentos de arrivismo e participação consciente dela no processo de 'troca desigual' entre a metrópole e a periferia... era mais ou menos fácil acusar a burguesia regional de ser parte do Centro, ou pelo menos de trabalhar para ele acima dos interesses da sociedade que governava.

Opondo-se à postura do comunismo ortodoxo, essas novas leituras permitiram a um grupo de intelectuais compreender que, ao contrário do que se defendia, a América Latina não estava num estado feudal avançando de forma promissora para o capitalismo, que seria o seguinte escalão do esquema -a cúspide seria o socialismo-. Ela já era capitalista, participando nesse sistema desde o século 16

[...] os impérios espanhol e português no Novo Mundo, declaravam Bagú e outros, eram basicamente empresas comerciais, para as quais os títulos e os exteriores "feudais" não passavam de disfarce (Love, 2011, p. 221).

Interpretou-se, então, que o capitalismo não chegara tarde à região, pelo qual era esperado se questionar sobre a inocência histórica da burguesia local, sublinhando a sua participação consciente naquele processo de drenagem. ${ }^{32}$

Dentro dessa crítica foi observado um processo de colonização interno, para Frank estimulado pela exploração transnacional, assim como uma cadeia que ligava a metrópole com o satélite "de Wall Street à menor aldeia latino-americana [...] todas as regiões estavam ligadas por uma troca desigual de bens e, serviços, [não existia dualismo] em consequência do capitalismo subdesenvolvido" (Love, 2011, p. 223).

Love expõe como essas ideias da tese de Frank, são fruto dos diálogos que ele estabeleceu com as teses do argentino Sergio Bagú -que defendeu a ideia de uma América Latina capitalista desde o século 16-, do russo-estadunidense Paul Baran -cuja ideia expus anteriormente, de que o capitalismo gerava desenvolvimento e subdesenvolvimento ao tempo-, do mexicano Pablo González -que desenvolveu a ideia do colonialismo interno, tão vivo em várias críticas comunistas posteriores- e do também mexicano Rodolfo Stavenhagen -que argumentou a inexistência de dualismo econômico na América Latina-. A síntese que Frank consegue entre as varias teses, Love

\footnotetext{
32 A suposta inocência das burguesias latino-americanas podiam explicar os problemas da etapa industrializante durante os anos de 1950. De fato -como mencionei- Cardoso e Faletto incluíam essa variável na compreensão que eles elaboraram dentro da CEPAL. Com certa claridade, é mais ou menos notório e compreensível que o escritório da ONU para os assuntos econômicos da região não se comprometesse com posturas ideológicas que o afastaram dos preceitos do desenvolvimento.
} 
a aclama em torno da figura retórica que o luxemburguês cunha para denominar a região e o Terceiro Mundo: "o desenvolvimento do subdesenvolvimento" (Love, 2011, p. 223).

4.

Segundo Love, para Frank a América Latina estava em um processo de subdesenvolvimento desde vários séculos atrás, caracterizado pelo exercício monopolístico da metrópole que só mudava, atualizando-se nas circunstâncias históricas. Nesse panorama, conseguir um desenvolvimento adequado, próprio e autónomo, só seria possível se fosse seguido o exemplo de Cuba... o único caminho era a revolução.

Ainda que as ideias de Frank circulem escritas desde 1967, tanto os antecedentes de onde ele bebe, como o momento mesmo do debate, estão acontecendo uma década antes disso. 0 texto de Bagú usado por Love é de 1949, o de Stavenhagen de 1965 os de Baran e de González aparentemente de 1952 e 1958 respectivamente. ${ }^{33} 0$ anterior, somado às críticas e os desenvolvimentos internos da CEPAL, mostram vários filtros assim como várias ideias presentes nas pautas dos debates da região. Filtros e ideias que sem dúvida alimentaram e foram alimentados por mais outras fontes de crítica, como a Teologia da Libertação ou as atualizações modernas de disciplinas como a arquitetura.

Segundo Bielschowsky, no início dos anos 1970 a preocupação da CEPAL parece ter mudado da "redistribuição para o crescimento", para "o crescimento com homogeneização social e fortalecimento das exportações”. Não vou tratar aqui a década dos anos 1970, assim como tampouco as outras à frente. Contudo, vale mencionar mais uma questão relacionada com a CEPAL para finalizar o assunto.

Com o fortalecimento das tecnocracias e dos centros acadêmicos regionais, e entre outras coisas- tanto pelo regime imposto no Chile a partir da queda de Salvador Allende e o estabelecimento da ditadura -o que diminui drasticamente o interesse e o

\footnotetext{
${ }^{33} \mathrm{Na}$ citação de Love não é totalmente clara a fonte nesses dois casos. No caso de Baran, Love cita parte de um titulo que pode ter sido publicado em 1964 -está incompleto-, mas a obra dele que parece mais próxima do postulado tomado por Love é The Political Economy of Underdevelopment publicado em 1952. Por sua parte, as referencias que oferece sobre o texto de González são posteriores da publicação de Frank, impossibilitando que foram pegadas. Nesse caso o título do livro Estudio de la Técnica Social de 1958, parece o mais próximo da ideia do colonialismo interno. Porém, essas são aproximações realmente superficiais da minha parte ao tentar rastrear as ideias a partir dos títulos dos livros.
} 
ritmo de convocatória em Santiago, sede do escritório-, tanto como com a ascensão das futuras e renovadas receitas neoclássicas -em um cenário de crise de petróleo, petrodólares em circulação e endividamento regional-, a influência da CEPAL nos governos da região desmoronou nos anos seguintes. Apesar disso, ela conseguiu se envolver nos debates mais depurados no interior da ONU em torno do desenvolvimento.

A partir da petição da ONU, a CEPAL entregou um grupo de relativizações nascidas do estudo das condições latino-americanas à "Declaração sob o Progresso e o Desenvolvimento Social", aprovada na Assembleia Geral da ONU em 1969. Reunidas dentro do grande "desenvolvimento integrado ao desenvolvimento humano", a CEPAL listou vários elementos como possíveis garantias para o seu sucesso. Uma delas, importante pelo que aconteceu alguns anos mais à frente, destaca dois preceitos chave: de uma parte, a ideia de que as populações deveriam participar das decisões relacionadas com o seu progresso. Por outra, a ideia planteada por Marshall Wolf em 1976 de que a priori não se deve "suponer la existencia de agentes politicamente capaces y deseosos de implantar un estilo de desarrollo deseable y factible" (Bielschowsky, 1998, p. 20), como reivindicado pelo circunstancialismo, tantas vezes mencionado durante meu texto.

As menções de Sunkel e Sánchez nas páginas anteriores são significativas do nível de participação da CEPAL nas definições desses elementos. 


\section{O Povo de Deus e a ampliação da ideia de pecado}

[...] Os crentes são movidos pela fé em um bem superior, e não pela crença na vida social como fim em si mesma, e por este motivo os não católicos que trabalham nas casas de hospitalidade muitas vezes se sentem meros espetadores (Sennett, 2012, p. 319).

\section{Solidariedade e status quo}

1.

Como afirma Loaeza (2008), em uma aliança estreita entre o Catolicismo e as elites tradicionais da região, a Igreja se converteu em pilar fundamental da organização social na América Latina desde a conquista europeia do 'Novo Continente'. Ameaçada apenas pelo liberalismo do século 19, ela se estabeleceu como instituição central na estrutura cultural das sociedades da região, sendo um dos maiores sistemas produtores de sentido para os seus habitantes. A sua universalidade, se atualiza no cenário regional em torno de um vívido e permanente sincretismo aonde respira parte do que é compreendido como popular: uma grande porção da identidade dos latino-americanos.

Nessas crenças vernáculas sincretizadas pode repousar a base de uma linha de identidade na América Latina, compreendida no senso comum como 'o povo'. Nas diferentíssimas expressões desse sincretismo religioso, manifesta-se uma heterogênea quantidade e qualidade de formas de reproduzir sentidos em torno dos quais, grupos de pessoas se sentem relativamente identificados. Por tal motivo um alto valor simbólico gravita em torno do popular e da ideia do povo -defende Loaeza-, quando visto politicamente. Esse sincretismo vai se acompanhar de uma certa debilidade institucional como traço do catolicismo na América Latina. Segundo estadísticas de Burns usadas por Loaeza, uma população que significava o $42 \%$ dos freguês do mundo -a latinoamericana- tinha $13 \%$ de sacerdotes disponíveis para ela o que até poderia explicar uma forma particular de se relacionar com a verticalidade institucional.

Agora, se a estabilidade da Igreja Católica foi posta em xeque na região na convulsão do século 19, é mais ou menos claro que após da Segunda Guerra Mundial, o seu papel se encontrara seriamente ameaçado. As mudanças sociais no marco da 
Modernidade na América Latina se misturavam com os seus impactos materiais. Não só as ideias liberais de separação do poder eclesiástico e do Estado estavam se concretizando, mas com elas, a realidade dos processos de modernização estavam se tornando absolutamente visíveis. De tal maneira, a pobreza regional que sempre preocupou linhas de intelectuais, mostrava-se com dramatismo na frente de um certo sentimento de frustração e até de desilusão enquanto terminava a década dos anos 1950. Se o processo pretendia eliminar a pobreza e a miséria, os indicadores marcados pelos processos de urbanização em relação com a ocupação que dinamizava a industrialização -por exemplo- exibia um panorama sombrio, como já mostrei em páginas anteriores.

Nesse cenário, enquanto as elites tradicionais se debilitavam no seu exercício do poder, as críticas provenientes de outras frentes se fortaleciam. Somava-se à instabilidade política -generalizada na entrada dos anos 1960-, o enfraquecimento das elites e a inocultável pobreza promovida pelo processo de modernização, o auge do comunismo, que, enquanto prometia ser uma saída para o desenvolvimento da região, corroía ainda mais aquele velho lugar ocupado pela Igreja Católica. Claro, aqui estou sendo generalista demais. É óbvio que as particularidades aparecem o tempo todo. Um exemplo podem ser as expressões daquele catolicismo social da década de 1830 do que fala Richard Sennett (2012), praticado por franceses e herdados, talvez por meio dos belgas, em várias experiências latino-americanas como no Chile da primeira metade do século 20.

Com eles, também foram visíveis vários esforços mais ou menos desinstitucionalizados, motivados pelas condições em que moravam as pessoas. Se materializavam desde a criação de partidos políticos, sindicatos e cooperativas até a formação de comunidades de base e movimentos sociais que se caracterizavam por serem intervenções diretas nas situações sociais. Como se aquilo que caracteriza Sennett da comunidade como vocação baseada na fé, se concretizasse em torno da existência do Outro, ultrapassando qualquer apelo pelo formalismo institucional "para o crente, a ajuda ao próximo deve ser resultado da crença em um Outro que transcende o humano" (Sennett, 2012, p. 320). 
2.

Em meio a esse panorama, a Igreja Católica se deparou com o problema do seu lugar na administração do poder. Entre as diferentes conjunturas, as estratégias que assumiu para se atualizar nesse contexto, se desdobram em ao menos duas grandes discussões. Dois grandes princípios que a meu ver, se imiscuirão e/ou fortaleceram nas categorias críticas de intelectuais na extensão da América Latina. Um deles era a ideia da justiça social, parte do núcleo vocacional e solidário da teologia cristã. Loaeza (2008) menciona como desde os processos de colonização do século 16, tais preocupações estiveram na vocação de vários sacerdotes no 'Novo Mundo'. Bartolomeu das Casas, Bernardino de Sahagún ou Pedro Claver, com as suas diferenças e locais de intervenção, foram defensores e denunciantes da exploração de negros e indígenas.

O segundo princípio -ligado do anterior- esta relacionado com a concepção da Igreja como do Povo de Deus. Um princípio que geraria o que Sennett chama "solidariedade explicita" em torno da ideia de que todos somos filhos de Deus (Sennett, 2012, p. 355). Agora, Sennett compreende esse princípio dessa forma, quando está olhando para determinadas práticas dentro dos Estados Unidos. Para compreender como elas se davam na América Latina, parece necessário colocar um matiz. Aquela ideia de serem filhos de Deus parece traduzida, ou melhor, se produz na interpretação ou hibridação sobre uma perspectiva popular, na que a solidariedade se orienta aos menos favorecidos pelos processos de modernização. Todos podemos ser filhos de Deus, sim. Mas os mais afastados da riqueza e do bem-estar, seriam os seus filhos mais genuínos e queridos.

\section{Um catolicismo latino-americano?}

1.

Em 1955 no Rio de Janeiro no Congresso Internacional Eucarístico, foi acordada a fundação do CELAM -Conselho Episcopal Latino-americano-. O contexto da perda do lugar da Igreja nas mudanças na região, acompanhado daquele sincretismo e as misturas do evangelho com o folclore, enquanto davam um certo matiz de identidade para os habitantes dos diferentes lugares da região, eram vistos no interior da instituição como fissuras indisciplinadas da teologia católica. Era preciso assumir a América Latina como um território para a re-cristianização de modo que era preciso pensar em novos métodos para a ação social 
[...] Su catolicismo [da América Latina] era un bagaje de tradiciones y ritos de índole cultural, que carecia de contenido religioso o de fuerza como instancia de autoridad espiritual. Nada distinguía el comportamietno de estos católicos del comportamento de un protestante o de un liberal. Gnadt Vitales em 1953 (Loaeza, 2008, p. 417).

É claro que as mudanças já percebidas no território preocupavam a hegemonia do catolicismo na região. Se foi experimentada uma relativa estabilidade desde a conquista, mais ou menos atrapalhada pelo liberalismo do século 19 , as práticas da modernização mostravam tangivelmente as ameaças nas décadas meridionais do século 20. Uma das mais temidas traduzida nos permanentes assaltos ao status quo, onde por exemplo o papel de ideologias políticas resultavam chaves. 0 medo pelo comunismo espreitando, promove um determinado deslocamento de temas estritamente religiosos no centro do catolicismo, para atender assuntos políticos e ideológicos. Já mostrei como esse medo sacode posturas conservadoras. Lembrando rapidamente, as políticas dos Estados Unidos em relação com América Latina também se movimentaram por causa desse temor. Nesse caso, possibilitando a ajuda e a cooperação técnica, num processo de tentativa homogeneização em onde viajava encapsulado o design. No caso da Igreja Católica, delineando o contorno de um inimigo contra o qual se opor

[...] A propuesta del papa Juan XXIII [no interior do CELAM] analizaron la amenaza del comunismo en América Latina [...] cuando se discutieron las posibilidades de avance del comunismo fue inevitable la reflexión en torno a las condiciones que propiciaban ese avance, y el debate a propósito de las estructuras que obstaculizaban una mayor justicia social (Loaeza, 2008, p. 418).

Pensar no problema da justiça social era entrar na discussão acerca das condições sociais, econômicas e políticas da América Latina. E era discutir o sentido de se reconhecer essas condições como próprias à sua realidade. As diferentes linhas críticas que vinham desenhando a injustiça social como embasamento de vários maus no desenvolvimento da região, pareciam se ligar ao canal de uma instituição do tamanho e influência histórica da Igreja Católica. Ela, por sua vez, abria mão de uma leitura determinista orientada desde Roma, para se 'sensibilizar' com a realidade da região e aceitar a 'interpretação' dada pelo contexto.

Não que a ameaça comunista tenha iniciado essa reflexão. Como expõe Loaeza, as preocupações da Igreja com os assuntos sociais tinham antecedentes. 0 papel dos protetores coloniais de negros e indígenas, como os que já mencionei; a encíclica Rerum 
Novarum do papa Leão XIII nos finais do século 19, aonde é contornada a ideologia social da Igreja, como uma via alternativa ao liberalismo e ao socialismo "a Igreja [tratando as] questões ligadas ao trabalho e ao capital quando os governos não se mostrassem capazes de apoiar os trabalhadores" (Sennett, 2012, p. 317); as conformações de sindicatos, organizações femininas, de estudantes e partidos políticos social-democratas durante os anos 1920 em vários países da região -seguramente o Chile como o mais notório-; o pensamento reformista cristão dos anos 1930; assim como as ideias do sacerdote operário que trabalhava nas fábricas e morava com os canteiros, no que claramente era privilegiado o fato de fazer, sobre o ato de falar... a ação acima do discurso.

Ao que parece, na profunda preocupação da Igreja por perder o seu lugar na sociedade por causa das mudanças da modernidade, o catolicismo seria novamente capaz de se reinventar, mexendo nos seus embasamentos políticos para visualizar uma posição onde se localizar de acordo com as circunstâncias.

2.

O Concílio Vaticano II, que poderia se entender como desprendido dessa grande inquietação, foi instaurado por João XXIII em 1962 e concluído por Paulo VI três anos depois. Debatendo o papel da Igreja na sociedade do momento -principalmente no relacionado com a paz em meio da Guerra Fria- o Concílio representou para Igreja uma relativa proximidade com o mundo protestante, assim como uma reinterpretação do seu embasamento no caso latino-americano. Se foi apresentado um debate religioso na discussão com Norte América e Europa, na América Latina o assunto gravitou em torno do social e do político. Está claro, se a Igreja como instituição estava preocupada com a determinação do seu lugar nas sociedades da época, qualquer aproximação na América Latina devia se dar pelo menos em diálogo com o que poderia chamar 'pauta regional', e ela era claramente política. Uma forte discussão que vinha se estabelecendo nas mais diversas camadas de intelectuais latino-americanos sobre a realidade da região, os impactos da modernização nos seus processos sociais e políticos e as diversas maneiras de compreender os enormes desafios que estavam à frente. Tudo isso em meio de uma azarada luta pela primazia ideológica, na que a região parecia um espólio.

À pobreza, vinda como preocupação desde pelo menos o século 19, a instabilidade econômica e até as primeiras ameaças de assalto à democracia nos governos da região, 
se somava a paranóia que significou para as elites da região e para os Estados Unidos a chegada de Fidel Castro em Havana em 1959. Cada uma dessas coisas estava preocupando de diferente forma os diferentes grupos de latino-americanos espalhados pela região. Já mostrei como a CEPAL, assim como o comunismo heterodoxo pretendiam compreender e resolver o assunto conforme a sua respectiva concepção do problema.

Posso dizer, por uma parte, que uma espécie de vocação respirava no interior da ideia de ajudar os mais desfavorecidos naqueles processos avassaladores de modernização na América Latina. Uma vocação que pode estar relacionada com o que expõe Sennett em torno dos católicos: enquanto a 'frieza' da ajuda emprestada de laicos com pessoas necessitadas acaba por impactar as condições de vida desse outro ser humano -com o que seguramente estará contente-, para o religioso existe algo mais "um Outro [sic] que transcende o humano" (Sennett, 2012, p. 320). Isso somado também a um esquema de controle social, como sugere Loaiza na resenha que faz do trabalho de Beatriz Castro

[...] Por eso, la visita domiciliaria era, al tiempo, una expresión de contacto directo del rico con el pobre; una visita religiosa con el fin de lograr, además, un control doctrinario, confesional, sobre la población y una expresión del domínio paternal de la elite conservadora. Era, en resumen, la demostración de la superioridad de la religión católica en la vida pública (Loaiza, 2010, p. 258).

Além dos níveis daquele debate que claramente excedem o meu interesse, a ideia de ajudar os outros estava fundamentada no imaginário de vários latino-americanos desde décadas anteriores ao Concílio. Por exemplo, Camilo Torres -sacerdote colombiano que já mencionei- tinha concepções muito claras sobre o serviço para os outros. Um desses é o sentido do conhecimento e do papel social da atividade científica

[...] El servicio del bien común, aun a costa del bien individual, no es sincero ni efectivo, sino se tratan de buscar los médios más aptos; el servicio del hombre no puede concebirse sin la ciencia y la técnica. Camilo Torres (Colômbia) 1956 (Aguilera, 2002, p. 70).34

3.

Nesse esquema, Loaeza (2008) apresenta um ajuste na maneira de compreender a ideia de "mudança social" no interior na Igreja. A instituição compreendia que dadas as

\footnotetext{
34 Outra forma como isso pode ter se cristalizado está ligado da fundação do grupo MUNIPROC (Movimento Universitário de Promoção Comunal) na Universidade Nacional de Bogotá, ao que, por exemplo esteve adscrito Rómulo Polo enquanto foi estudante de arquitetura (Polo, 2014a).
} 
circunstâncias regionais, a mudança era simplesmente imparável na região. Mas, acompanhando semelhante concepção -para quem se preocupa com o status quo, a definição de mudança era mais do que um problema teológico-, a Igreja aceitara que a transformação do mundo estava nas mãos dos indivíduos, não sendo mais um produto da vontade de Deus. Mudança e ação nos indivíduos: um panorama visivelmente perturbador para os Católicos conservadores.

Para Loaeza, a inclusão daquelas ideias e o tom no que são expostas no Concílio, teoricamente terminariam comprometendo a missão da Igreja em "uma antropologia", ligando-a com o princípio da mudança social, quando era interpretada na América Latina “enfatizaba la autonomia de lo temporal [...] [determinando] que la misión de la Iglesia era estrictamente religiosa" (Loaeza, 2008, p. 420). Se ela tem razão, tais concepções terminam se concretizando nos documentos, dado que -entre outras coisas- vários deles foram redigidos por sacerdotes latino-americanos. Alguns dos quais foram formados por jesuítas progressistas -em relação com uma Igreja para os trabalhadorese outros foram formados no secularismo das ciências sociais europeias. Em um caso e no outro, esse grupo de sacerdotes tiveram acesso aprofundado às teses que se debatiam acerca dos desafios que propunha a época.

Em tudo isso consigo detectar uma característica, que na sua forma também realcei no caso do argentino Raúl Prebisch. Aqueles sacerdotes latino-americanos -assim como Prebisch e outros tantos intelectuais- em comunhão com as grandes teses sobre a mudança e os desafios do tempo, também estavam claramente sensibilizados com a sua própria experiência no cenário. Nessa experiência tudo se misturava. No caso daqueles sacerdotes, produzindo determinadas interpretações do que era orientado desde o centro da instituição e que terminaria disciplinando as ações que se empreenderiam no futuro. Ou simplesmente chegando como justificativas das ações que já vinham sendo praticadas na região. ${ }^{35}$

A grande conclusão do Concílio foi que a Igreja devia ir ao encontro do mundo. Uma Igreja voltada para as pessoas, conduzindo a conversão da sociedade no sentido primordial do catolicismo, por cima da instituição

\footnotetext{
35 Não digo que esse seja um 'jeito' latino-americano na prática do sacerdócio. Tento não cair na armadilha. Afirmo que assim procedeu uma linha de sacerdotes da época. Generaliza-o seria chauvinista e realmente insensível com os fatos. Se Camilo Torres é um dos mais importantes latino-americanos na conceitualização dessa fação da Igreja, um outro colombiano foi 'o encarregado' de dar uma estocada final em todo esse movimento. 0 sacerdote conservador Alfonso López Trujillo.
} 
[...] Esta visión propició que florecieran las particualidades nacionales y que se impusieran a la vida de la Iglesia Católica de suerte que el aggiornamento [sic] convitió al conjunto eclesial en un mosaico de realidades yuxtapuestas (Loaeza, 2008, p. 423).

4.

Sair para encontrar o mundo era aceitar a entrada dos laicos, do folclore e, da sua mão, era construir um certo essencialismo cultural... um eixo em torno do qual seria fortalecido o catolicismo como elemento da identidade social. Era compreender que a ação pastoral representava a prática da caridade, da difusão das crenças e da assistência aos necessitados. Como marco para o trabalho solidário, de combate à pobreza e de denúncia à exploração. De novo, as condições dessa "América do pesadelo, exotismo e sonho" (Cancelli, 2003), determinando tanto a tradução de princípios que chegam de fora, como a institucionalização daquelas práticas que nascem na urgência do contato com as circunstâncias.

Mas, se toda essa aparente quebra tinha deixado aqueles elementos expostos, fica claro que o Concílio, na prática, deixa na mesa a ideia de que a Igreja são os fiéis. Na América Latina, dadas as suas práticas e leituras, aqueles fiéis são o povo, de tal forma que a Igreja seria o Povo de Deus. Trabalhadores, pobres, marginados, etc., todos eles multiplicados em número dentro dos diversos argumentos latino americanistas, estavam incluídos dentro daquela concepção. Quiçá, toda aquela vocação voltada sobre a assistência dos desfavorecidos permitia cumprir com um determinado mandato divino. Não sei. $\mathrm{O}$ importante para meu argumento é a espécie de sacralização que se outorga às figuras dos desfavorecidos... sacralização que, levada ao estatuto institucional, permitira a conformação de identidade de uma imensa população latino-americana, que podia se sentir institucionalmente acolhida. 0 popular como característica essencial da oprimida e exótica América Latina. Trabalhadores e pobres como sinônimo do Povo de Deus, como sinônimo do verdadeiro. Quando me pergunto pela importância que lhe outorgam os fundadores de ALADI aos substratos populares como final do trabalho dos designers e propósito das suas criações, parece necessário ver como essa defesa é parecida com a construída pelo catolicismo latino-americano, como uma construção de sentido. 


\title{
Ação pastoral e autonomia
}

1.

Uma conjuntura não tão inesperada, estava se dando em simultânea com o Concílio. Dada uma linha histórica particular, na que estiveram envolvidas determinadas práticas em torno da democracia, o Chile conseguiu que uma pauta social orientasse o governo. ${ }^{36}$ No ano 1962, o catolicismo chileno tinha conceituado a desigualdade e a injustiça social, praticamente explicando-a pela nula distribuição da riqueza e da propriedade privada. Uma pauta evidentemente embasada nas críticas e propostas que trabalhavam os intelectuais da CEPAL no momento, que já nesse momento -entre outras coisas e como expus em páginas anteriores- dialogava com as facções heterodoxas do comunismo da região.

Aquela linha democrática, particular na história chilena da primeira parte do século 20, levou ao poder ao governo democrata-cristão de Eduardo Frei. Visto como uma terceira via na convulsionada luta ideológica que já representava a presença do liberalismo e o coletivismo, o governo Frei representou pelo menos a conquista de vários princípios para os mais desfavorecidos, assim como um bloqueio do avanço do comunismo na região... recolhia liberais, progressistas e radicais... era visto com ilusão, de fato em um momento se pensou como um modelo que poderia se replicar em outros países da região como afirma Loaeza

\begin{abstract}
[...] El programa de gobierno del presidente Frei [1964-1970], denominado Revolución en la Libertad, tenía tres puntos fuertes: la reforma agraria, la chilenalización del cobre que hasta entonces estaba en manos de empresas norte-americanas, y un amplio plan de vivenda y programas de promoción popular en los barrios pobres urbanos. Esta experiencia democrata-cristiana fue un dato importante en el processo de radicalización de los católicos latino-americanos [...] porque proporcionó el impulso original a la movilización y organización de sacerdotes, religiosos y laicos activistas en los médios populares (Loaeza, 2008, p. 422).
\end{abstract}

Aqueles pontos eram também uma política para melhorar as condições de vida dos chilenos. Distribuir a riqueza, a terra e nacionalizar a exploração do maior produto para a exportação supunha um enriquecimento relativamente homogêneo, que permitiria responder às críticas que já tinha levantado a CEPAL, em função do fracasso da

\footnotetext{
${ }^{36}$ Alguns detalhes dessas particularidades são apresentados na coletânea de Aldo Panfichi (2002), assim como, especialmente no texto de Gonzalo de la Maza e Carlos Ochsenius (2010).
} 
Industrialização por Substituição de Importações. Contudo, dados certos aspectos políticos na prática chilena, o esperado do governo de Frei não se cumpriu, decepcionando os mais diversos frentes ideológicos na América Latina que tinham se deslocado das suas promessas:

[...] En 1968, al mismo tempo que se inauguraba en Bogotá, Colombia, el Congreso Internacional Eucarístico y la II Conferencia General de CELAM, grupos importantes de la juventud democrata-cristiana le dieron la espalda a la vía reformista, denunciaron la injusticia social, la explotación, la opresión y la incapacidad de la Iglesia institucional para resolver estos problemas (Loaeza, 2008, p. 422). ${ }^{37}$

2.

A partir do exposto por Loaeza, não parece tão descabido compreender o Concílio Vaticano II como um evento no qual foi possível consignar práticas que já vinham acontecendo em várias frentes do exercício pastoral da Igreja. Da mesma forma, a experiência chilena oferecia um exemplo de como essas práticas conseguiram se alinhar com o sentido social das condições de um enclave cultural concreto, com o firme propósito de resolvê-las. Pode-se ler nessa experiência uma atualização ou uma tradução do que foi debatido no coração do Concilio... sim, claro que sim. Mas explicar aquela experiência só pela atualização e/ou a tradução é novamente, incompleto e artificial.

Como na maioria dos outros países da região, no Chile existe uma linha comprida que liga facções do clero chileno com aquelas práticas sociais da Igreja. Por exemplo, Jesuítas aparecem no panorama pelo menos desde a segunda metade do século 19 em trabalhos de intervenção social. Desde a prática de trabalhar e morar com os desfavorecidos na imagem do sacerdote canteiro que mencionei, até as afiliações da metade do século 20 com os programas de desenvolvimento econômico social, podem ilustrar esse tipo de práticas na região, nas beiras do que esta escrito, estipulado e até aceitando como interpretação católica desde Roma. Em uma sociedade que concebe a miséria e a pobreza como flagelos, o sentido de chamado de uma linha de integrantes de uma instituição como a Igreja Católica, foi organicamente promovido no interior da

\footnotetext{
37 Para esse momento da citação de Loaeza, Camilo Torres já tinha sido afastado da Universidade Nacional, do sacerdócio -do qual se demitiu em 1965- e do movimento politico que fundou, se somando à luta armada no Exercito de Libertação Nacional -ELN-. De fato, para esse momento Camilo Torres completava algo mais de dois anos de morte, logo de um enfrentamento com o exército colombiano no Departamento de Santander ao nordeste do país.
} 
assistência... com a possibilidade de, se não conseguir superar esses estados, pelo menos tornar mais plausível a cotidianidade dos outros. ${ }^{38}$

O Concílio Vaticano II terminou em 1965, especificamente no dia 8 de dezembro. Data próxima à de comemoração do fim do primeiro ano do governo de Eduardo Freire no Chile -iniciado em 3 de novembro de 1964- e com os primeiros dois meses de participação guerrilheira de Camilo Torres nas filas do ELN.

No meio daquele cenário e dentro do panorama de, por um lado a redação do Concílio Vaticano II, somada àquela experiência política no Chile, ocorreu a segunda conferência do CELAM. Sediada em Medellín, Colômbia em 1968 -três anos após do narrado no parágrafo anterior-. Essa foi a oportunidade de 'traduzir' as diretrizes do Concílio Vaticano II, ajustando-as nas interpretações da região. Loaeza apresenta antecedentes vivos para a Conferência.

Por uma parte, a instaurada Revolução em Cuba a que -em contra de muitos prognósticos- estava próxima de completar os seus primeiros dez anos. Acompanhada de outros eventos e estabelecendo a mudança como eixo social, a Revolução Cubana oferece a disjuntiva, entre um pensamento reformista e um pensamento revolucionário, radicalizando a mais diversa gama de intelectuais latino-americanos, entre os quais haviam vários sacerdotes. Assim como foi se endurecendo na postura contra o capitalismo, a Revolução também foi se radicalizando em torno da ideia da ação por cima das ideias. Essa postura sem dúvida uniu uma grande quantidade de intelectuais na região naqueles anos, como por exemplo mostra Gilman (1999).

Acompanhando a Revolução, Loaeza também apresentara a experiência chilena como antecedente vivo da Conferência em Medellín. Compreendendo nela uma linha histórica de conquistas, Loaeza considera que a ideia da democracia cristã como uma terceira opção contra do liberalismo e o socialismo em meio da Guerra Fria, congregava um grande grupo de sacerdotes que procuravam a mudança social, não importando pelo menos no início- se ela ia ser conseguida por meio de reformas ou pelo caminho das armas.

\footnotetext{
38 Adriana Petra, expõe as relações do sacerdote belga Roger Vekemans, o sociólogo brasileiro Fernando Henrique Cardoso e o cientista político argentino José Nun na conjuntura do "Projeto Marginalidade", durante os anos sessentas do século 20. Usando recursos da Fundação Ford, esse trabalho foi acusado como um caso de espionagem sociológico (Petra, 2009).
} 
O terceiro elemento colocado por Loaeza como antecedente foi a trajetória e a transformação da figura de Camilo Torres em mártir. Estava fresco. Já mencionei como ele poderia ser visto como um símbolo do comprometimento com o chamado e a ajuda dos desprotegidos. Um cidadão acomodado com todas as possibilidades sociais e econômicas que se preocupa com os outros... que se despoja do seu conforto para atender os desfavorecidos. Filho de uma família liberal de classe alta de Bogotá, Torres se ordenou sacerdote em 1947 enquanto estudava direito na Universidade Nacional na cidade. Sensibilizado com problemas sociais, em 1954 viajou para Bélgica para estudar sociologia na Universidade Católica de Lovaina. Rueda afirma que estando lá, se ligou com a Democracia Cristã, o movimento sindical cristão e com os grupos de resistência argelina que estavam em Paris (Rueda, 2002). Ele fez mais alguns cursos na Universidade de Minnesota e retornou à Colômbia. Ministrou aulas, promoveu o trabalho de intervenção social em áreas marginais urbanas e, em conjunto com Orlando Fals Borda, fundou o primeiro programa de Sociologia do país, na Universidad Nacional em Bogotá.

Sua leitura dos acontecimentos sociais e políticos do país, lhe fizeram compreender que a única via possível para a mudança das condições de vida dos marginais e dos pobres da região, estava marcada pela aliança com o marxismo e o socialismo "incluso a considerar que la violencia era lícita en situaciones de grave injusticia social” (Melo, 1991, p. 1). Em março de 1965 lançou em Medellín o Frente Unido, base política que pretendia unificar os diferentes grupos populares, comunistas, marxistas, esquerdistas independentes e dirigentes sindicais. Nesse momento, ele já não era mais sacerdote.

Segundo descreve Melo, Torres deixa se convencer pela embriaguez do argumento revolucionário como única opção para a mudança do país. Em outubro de 1965 'partiu para a montanha' se somando às filas do ELN -Exército de Libertação Nacional- nascido uns meses antes com apoio cubano. Em janeiro de 1966 anunciou publicamente a sua adesão à guerrilha, um mês antes de morrer no seu primeiro combate -completava 37 anos- 
[...] La imagen de Camilo que recorrió el mundo después de su muerte era la de un héroe y mártir que había dado su vida por los pobres de Colombia y de América Latina. Y su influencia se sintió. Surgió una guerrilla urbana en Argentina que invocaba su nombre. Chile vio el nacimiento de 'Sacerdotes para el Socialismo', un movimiento que ayudó a abrir camino para el gobierno de Salvador Allende. Más tarde, en Nicaragua, los hermanos Cardenal y otros distinguidos clérigos iban a comprometerse con la revolución sandinista contra Somoza y con la construcción de un Estado nuevo. Todos, de algún modo, encontraron su inspiración en Camilo. El fue el precursor. Para comprobarlo, es suficiente recordar la fecha de su sacrificio: Camilo murió en las montañas de Santander un año y medio antes de la quijotesca aventura y posterior muerte del Che en Bolivia (Broderick, 1980).

Camilo Torres é um personagem que marca uma geração. A citação de Broderick dá pistas da magnitude da sua imagem assim como as anedotas de pelo menos dois dos fundadores da ALADI, retribuindo o sentido da sua importância na vida cultural da região. Esse Camilo Torres é aquele que funda MUNIPROC, o movimento universitário de intervenção social na Universidad Nacional em Bogotá, no qual participou Rómulo Polo sendo ainda estudante de arquitetura. Da sua parte, Jesús Gámez, lembra emocionado

[...] En Bucaramanga estudié en el Colegio Santander. Yo fui compañero de Jaime Arenas y de Ricardo Lara... conocí con ellos al padre Camilo Torres [...] era el año 58, Cuba, Revolución cubana, esa época... pero yo no era activista, mis amigos eran activistas, yo los acompañaba (Gámez, 2016).

Só para enfatizar o sentido. Nas suas respectivas juventudes, Camilo Torres teve uma relativa proximidade pessoal tanto do primeiro presidente, como do primeiro tesoureiro da ALADI. Essa proximidade poderia se explicar pela afinidade ideológica com que os dois jovens estudantes se aproximam à crítica do mundo durante os anos 1970 alinhado com vários dos ideais que defendia Torres.

3.

A Conferência inaugurada em Medellín, se caracterizou pelo abandono da posição eclesiástica. De tal maneira, as diferentes orientações, quando indeterminadas, foram traduzidas nas condições que cada situação apresentava e não exatamente impostas. Como já mencionei, isso permitira a entrada de um relativo pluralismo na visão da Igreja, aonde as particularidades governavam. Como no caso da arquitetura que referi em páginas anteriores, ou nas conceituações da crítica econômica à tecnologia e ao 
desenvolvimento, a reivindicação pelo específico estava no coração do assunto... era uma reivindicação pelo respeito das situações... era a epistemologia das circunstâncias.

Mas, aquela desconcentração era acompanhada -talvez estimulada- pelas preocupações de longa data na região, relacionadas com o conflito social e a luta de classes. Não que elas fossem as noções com as que se debatia o problema desde antes, mas sim como a forma que adquiria no cenário de vários intelectuais da região durante o segundo tercio do século 20. Tais denominações -conflito social e luta de classes- além de estarem deixando transparecer a vivida influência das teorias em debate, pareciam se sintetizar no princípio da mudança social, como ideologia secular incorporada na preocupação do sacerdócio latino-americano que -como mencionei alguns parágrafos atrás- colocava 'o povo' como epicentro da reflexão católica. Finalmente, ele tinha sido compreendido como a Igreja de Deus.

O que se relacionava com 'o povo'? O pobre, o marginal, o popular. Era a revelação, a verdade, o sentido. Naquela perspectiva, tudo que fora empreendido, toda ação pastoral e laica, devia tê-lo como propósito. No final, tudo teria a ver com que o povo conseguira superar as suas carências melhorando a sua qualidade de vida

[...] La Iglesia como Pueblo de Dios recibió una interpretación inequívoca de una Iglesia sólo para los pobres [...] el pueblo [sic] era la fuente de la revelación espiritual y de la autoridad religiosa [...] lo importante [...] eran las condiciones de vida del pueblo (Loaeza, 2008, p. 424).

Se o povo tem em torno dele tantas virtudes e significa em tal nível tantas coisas sublimes, era apenas esperado que vários conceitos teológicos fossem ajustados em torno dele. Um desses seria a ampliação da ideia de pecado, que por sua vez poderia ter duas características simultâneas. Na primeira, as preocupações seculares das lutas de classes e o conflito social ofereciam um aparato conceitual, no qual a injustiça social se incluiria como pecado. Desde aqueles que não permitissem a plenitude da vida, até o opressor violento encaixariam nessa dimensão do pecado. Era uma tradução mais ou menos esperada no interior de uma facção católica que bebia da crítica comunista. Lembro aqui a forma como naquele momento a heterodoxia comunista assinalava tanto a prática da drenagem quanto os seus atores latino-americanos -as elites-, como explicação da perpetuação do estado de subdesenvolvimento da região... fatores da pobreza. 
A segunda característica daquela ampliação, está relacionada com a ambiguidade para aceitar a violência. Como uma apologia para a revolução, vários sacerdotes compreenderam a violência como caminho legitimo quando se procurava a quebra das condições da opressão. Mas essa mesma linha de raciocínio rechaçava enfaticamente a violência, quando ela era institucional e sobretudo, quando era uma promoção estrutural, ou seja, que perpetuava a condição de marginalidade do povo. Em último caso, se o povo é a Igreja de Deus, e ele está compreendido por pobres e marginais, tudo que não permita o seu desenvolvimento será, no mínimo, compreendido como pecado e o seu promotor, será visto como pecador.

Para a crítica econômica e sociológica, heterogeneidade e assimetria produtiva perpetuavam a América Latina em uma posição de dependência, posição que era uma clara garantia para que as suas camadas populares seguissem na marginalidade e fossem oprimidas. 0 tom das discussões que aconteceram em Medellín naquela Conferência em 1968, realçavam -sem falar neles- que esses já cabiam na definição de pecado.

Se os tecnicismos da crítica econômica e sociológica que tentei mostrar no tópico anterior -quando falei da CEPAL- eram discursos de especialistas que precisavam de tradução na cotidianidade, a ideia de pecado era fácil de digerir para qualquer católico no canto que se encontrara. No final, todos esse tecnicismos estavam sintetizados na ideia de injustiça social.

Pobre, marginado, popular, incluído no olhar exótico do moderno, reativa o sentido da vocação e do chamado em vários sacerdotes católicos e pode estar levantando uma bandeira onde aquelas características facilmente viram escusas 'da diferença', 'do próprio', 'do nacional'. A ideia de mudança, atualizando aquela mesma vocação, traduzia noções base de lutas nacionalistas em várias partes do mundo.

A consciência nessa crítica, em evidente diálogo com as diferentes fontes que a produzia -notoriamente com a heterodoxia comunista-, permitia que na Conferência fosse considerada a ideia de que o subdesenvolvimento da América Latina -centro do problema da injustiça social e da violência- era uma condição promovida pelo imperialismo, explicada a partir da vigência das estruturas que a perpetuavam. A partir daí, a sua inscrição com o diagnóstico da Teoria da Dependência, recentemente formulada no Chile a partir do trabalho de Fernando Henrique Cardoso e Enzo Faletto. Nesse contexto, é possível explicar o nascimento da conhecida Teologia da Libertação, 
como corrente teológica que pretendia problematizar conceitos da Teologia Cristã em função da problematização humanística e sociológica.

4 .

Além dos detalhes que relacionam esses princípios com a liturgia e a ação pastoral do catolicismo na região, é interessante reconhecer esse percurso de um pouco mais de uma década, como um processo no qual o olhar da América Latina sobre a América Latina conseguiu se manifestar no interior da Igreja Católica como instituição. Vários elementos poderão se assinalar como herdeiros dele. Um deles será com certeza, o fortalecimento de um elemento de identidade regional. Já o catolicismo permitia compreender no imaginário racial, que do Rio Grande para acima é uma coisa e que dele para abaixo é uma outra. Com a concreção do olhar latino-americano do catolicismo estava-se formalizando uma prática regional que, ainda respondesse às diretrizes europeias, era uma visão própria que entre várias características, era antropofágica e circunstancial. Era a América Latina dizendo o que pensa dentro da ressonância de uma instituição do alcance social e geográfico da Igreja Católica. Mas também era um dos elementos de maior sensibilidade cultural, que permitia que essa Comunidade Imaginada chamada América Latina, fosse identificada com contundência. ${ }^{39}$

As fações conservadoras dentro do Vaticano nunca conseguiram aceitar a Teologia da Libertação, nem os conceitos e interpretações que ela significava e promovia. Pelo menos desde 1972 tentava miná-la. Em 1978 João Paulo II assumiu como pontífice máximo. Com ele entraria uma ideologia de ferro que pretendera não só centralizar de novo a verticalidade do poder em Roma, como rechaçar a ideia da Igreja popular, unificar as interpretações e claro, repelir a Teologia da Libertação. Seguindo Loaeza, já no discurso de abertura que ofereceu na Terceira Conferencia do CELAM -em Puebla, México- apenas uns meses apos da sua eleição, entre outras coisas o novo Papa afirmou que a teologia do catolicismo não pode se basear em humanismos ateus; era a oportunidade de "borrar de los planteamientos católicos en la región toda huella de la influencia del análisis marxista que estaba tan presente en los años anteriores" (Loaeza, 2008, p. 430).

\footnotetext{
39 Religião, língua e território como a triada que conforma claramente a imagem de um nacionalismo do tamanho dessa região. A língua faz parte da fórmula que apresenta Benedict Anderson (1993), não necessariamente da realidade cultural da América Latina. Daqui a pouco contornarei.
} 
O rumo seria corrigido... seria resgatado, logo após esses anos obscuros de interpretações livres e folclore em frenesi. Universal: sim, claro, a Igreja seguirá sendo universal! mas nas condições determinadas acima de particularismos e desvios culturais. A verticalidade e rigorosidade daquele olhar faz com que desde Roma se castigasse duramente contraditores como ocorreu com Leonardo Boff em 1985. Naquele momento, o sacerdote brasileiro foi castigado com um ano de silêncio -o que quase se repete em 1992-. Em 1983, em Managua, na Nicarágua, igualmente o Papa reprendeu sacerdotes que faziam parte do governo sandinista. Vários outros desviados seriam redimidos daquelas trevas. 


\section{América Latina, uma Comunidade Imaginada}

[...] el discurso no es sobre América Latina sino desde América Latina, es decir desde un particular soporte cultural (Pini, 2008, p. 520).

[...] El sueño bolivariano de alcanzar una federación de naciones libres y solidarias fue frustrado por la intromisión de potencias foráneas. Por eso, a finales del siglo XIX, José Martí afirmaría con justicia que "Bolívar tiene que hacer en América todavia". En este dilatado processo, surgió también un pensamento social avanzado [...] que [...] incorporó sus sueños de justicia al imaginário compartido por las jóvenes naciones americanas [...] la estructuración de un discurso cultural autóctono, los debates sobre la identidad nacional, así como las expresiones ideológicas y estéticas propias de [...] América Latina y el Caribe, han sido temas insoslayables de la reflexión y la creación (Ayerbe, 2012, p. 7 e 8).

\section{Não saxã, latina!}

1.

Em Bogotá 1980, os fundadores da ALADI estiveram claramente interessados em determinar os limites, a jurisdição e a discricionalidade daquela ocupação chamada design, que era praticada na região. Claro que sim! Eles tentaram definir o perfil do designer latino americano, os problemas que o design devia atender como campo profissional e o seu papel social. Contudo, enquanto eles apresentavam aquelas definições, também reivindicavam a autonomia cultural, econômica e tecnológica da América Latina como território, com tal nível de convicção, frequência e similaridade entre delegações, que por momentos isso parece mais importante que as próprias justificativas sobre o design. Era vindicada uma autonomia daqueles que não permitiam à América Latina criar a sua própria realidade, como expressou no âmago da ALADI, Oscar Pamio (1981). Uma autonomia para decidir e produzir desde as circunstâncias para as circunstâncias.

Aquela reivindicação dos fundadores da ALADI procurava quebrar a histórica cadeia que amarrava a tecnologia estrangeira com a economia da região, argumentos alinhados das preocupações que já mencionei da CEPAL. Uma cadeia que terminava materializando uma insuportável dependência cultural, por tanto um alimento de uma forte mirada nacionalista. 
Como linha discursiva, essa postura nacionalista tem uma longa trajetória na região. Ela facilmente pode ligar esses intelectuais fundadores da ALADI, com algumas das ideias de projetos unionistas, como as levantadas por Simón Bolívar no Congresso do Panamá em 1826. Como nos casos de José Cecilio del Valle ou Francisco de Miranda, o projeto bolivariano procurava uma identidade continental, a necessidade de criar relações de cooperação entre as novas repúblicas e sobretudo, preservar a independência (Scarfi, 2013, p. 89). ${ }^{40}$

A necessidade de não ser anacrônico me obriga pensar que a ideia se ajusta e se resignifica no tempo. Porém, a presença da estrutura argumental, assim como a frequência em que se apresenta nos mais diversos tipos de intelectuais da região desde esses anos, na mais diversa qualidade de expressões e formatos durante aproximados 160 anos, é simplesmente notória. Parece-me que dessa forma são relativizadas várias leituras sobre como a América Latina tinha aceitado influências estrangeiras para se definir culturalmente. São organicamente questionados axiomas que, por exemplo, pretendem explicar o design pela vontade europeia no nosso 'exótico território'.

Nas seguintes páginas pretendo traçar a linha que liga o patente fervor nacionalista-latino-americano dos fundadores da ALADI, com aquela preocupação do século 19. Por favor, aceitem a minha insolência historiográfica: me parece que no caso Latino-americano posso realçar um longo 'unionismo' para um determinado grupo de intelectuais da região, que liga os anos 1820 com, pelo menos 1988, ano no qual foi iniciada a redação das novas Constituições politicas nos países da região. ${ }^{41}$

Sei que a forma como é recebido o 'unionismo' varia tanto no tempo, como nos locais. Uma coisa é a maneira como por exemplo parece ter sido recebida a ideia da federação regional proposta por Bolívar na chamada Confederação Argentina -em 1825- e como aquela recepção é reavaliada e ajustada nas conjunturas dos finais do

\footnotetext{
${ }^{40}$ Não aprofundarei ao não ser o eixo do meu argumento. Aquelas sugestões em torno da união, já aparecem tratadas em escritos de Bolívar como a "Carta de Jamaica", escrita em setembro de 1815. No percorrido desse escrito, Bolívar faz uma leitura do que vê das realidades politicas da região. Entre vários aspectos, ele reconhece as diferenças entre as sub-regiões e os problemas que implica pensar no projeto de uma 'grande pátria'. Porém reflete sobre a ideia da união como o caminho para o que chamou "regeneração". Uma união para se proteger do assedio dos intrusos, segundo o compilador da obra -pelos anos 1815- a tentativa chegada de Napoleón dada a sua derrota em Waterloo. Ver Carta al Excelentísimo Presidente de las Provicias Unidas de la Nueva Granada (22 de agosto de 1815) (Bolívar, 2009a) e Contestación de un Americano Meridional a un caballero de esta isla "Carta de Jamaica" (6 de septiembre de 1815) (Bolívar, 2009b).

${ }^{41}$ É com a conjuntura das novas constituições que entra em rigor e mais ou menos generalizada, a mais famosa fase do Neoliberalismo na região. Ela, como tratarei em um capítulo posterior, marca novas lógicas nas relações sociais na América Latina, quase virando marco histórico.
} 
século na Nação Argentina. Várias afirmações de Roque Sáenz Peña -presidente argentino entre 1910 e 1914- demonstram isso (Scarfi, 2013, p. 95). Como uma constante, uma latente imposição dos estadunidenses, nesse caso nas formulações do Projeto Panamericanista nos anos 1890, estimulavam esse tipo de buscas em intelectuais como Sáenz. Frente à ameaça da soberania e a autonomia, a estratégia parecia aproveitar e fortalecer projetos que circulavam pela região com uma certa antecedência. Se tratava de robustecer a ideia de uma grande liga que permitira preservar a autonomia e a independência das nações latino-americanas. Nesse imaginário, as fixações na religião, no território e na língua iam se impor como recurso didático.

2.

Poderia dizer que a ênfase no progresso técnico -ligado do "ideal do prático" que guarda o Projeto Moderno-, na região também esteve unido à ideia de autonomia e soberania nacional desde o início. ${ }^{42}$ Tanto a autonomia quanto a soberania, eram compreendidas como garantias do progresso e conquista de uma nova sociedade, que por sua vez estaria apoiada sob um esforço de definição de aquilo que é nosso... uma busca essencialista da identidade. Claro, inserido dentro de um processo de recente emancipação longo e doloroso -sobretudo para as ex-colônias espanholas-, tudo esforço parecia virar estratégia para conservar a independência, como tinha sido defendido por perspectivas como as de Bolívar.

O sentido essencialista será realmente ativado tanto pelos conflitos entre a França e o México, como, sobretudo, pelas práticas expansivas dos Estados Unidos. A guerra e possessão de outrora territórios mexicanos nos anos 1850 (Texas, Califórnia, Novo México, Arizona, Utah, partes de Colorado, Wyoming, Kansas e Oklahoma); o apoio público do governo dos Estados Unidos à invasão do pirata William Walker na Nicarágua entre 1855 e 1860; a declaração de guerra do governo norte-americano contra Espanha, para instituir a independência de Cuba em 1898 -dessa confrontação Estados Unidos toma possessão de Porto Rico, Filipinas e Guam (Betancourt, 2013, pp. 140-141)-; o projeto panamericanista, promovido pelo governo dos Estados Unidos também nos anos 1880; a independência do Panamá para Colômbia em 1903 graças às ações separatistas apoiadas pelos norte-americanos, entre outros acontecimentos, fez com que vários 
intelectuais da região olhassem com reserva o grande vizinho do norte. Nesse momento, -bem nos anos vinte do século 18- era eloquente a ironia com a que intelectuais da região tinham recebido a Doutrina Monroe e completavam o seu mote: "a América pelos americanos” rezava, “...do Norte” completavam os americanos do Centro e do Sul. ${ }^{43}$

As ameaças expansivas dos Estados Unidos sobre os seus vizinhos do sul, promovidas entre outras coisas pelo seu interesse por fazer um canal interoceânico na Centro América -no que esteve envolvido o pirata Walker na Nicarágua em 1850 (Quijada, 1998)-, redesenhou imagens que já tinham sido esboçadas sobre os norteamericanos desde as guerras de independência contra a Espanha.

Desse temor e das evidências do assédio, que fora concretizada a ideia de Bolívar sobre a união. Como imaginário, ela se convertia na base para passar rapidamente daqueles elementos que permitiam compreender a identidade nacional, para as características que justificassem a existência de uma região unida desde o Rio Grande até o Cabo de Hornos. Com isso se construía a ideia de que a aliança regional impediria a expansão dos Estados Unidos sobre esses territórios "la raza de la América Latina, al frente tiene la sajona raza, enemiga mortal que ya amenaza" escrevia o colombiano José María Torres Caicedo em 1856 (Pabón, 2012, p. 30).

Sentindo aquele assédio, as repúblicas emergentes da região desenharam um traço no território -uma Comunidade Imaginada diria Anderson (1993)- como forma de consolidação da autonomia e da soberania. A língua, a religião e a ideia de que essas populações compartilhavam os mesmos problemas e desafios desde a época em que eram colônias, davam o substrato para as ilusões de ser iguais. A ideia de uma América não Saxã mas Latina, era concebida em 1857. Uma projeção sobre as ex-colônias espanholas na região que procurava defender a soberania e a autonomia da região. 0 Brasil não estava inicialmente considerado nos cálculos dos intelectuais que se

\footnotetext{
${ }^{43}$ Scarfi apresenta uma anedota anti-monroe na que estiveram envolvidos Roque Sáenz pela Argentina e José Martí por Cuba na Primeira Conferencia Panamericana em Washington em 1889. Posterior à Conferencia, Martí celebra as reações argentinas às abordagens estadunidenses e ao seu latente exercício imperialista: "pero cuando el delegado argentino Sáenz Peña, dijo como quien reta, la última frase de su discurso sobre el zollverrein, la frase que es un estandarte y allí fue una barrera 'Sea la América para la humanidad', todos como agradecidos, comprendieron lo que no se decía, y le tendieron las manos" José Martí (Cuba) em 1890 (Scarfi, 2013, p. 92).
} 
preocuparam por esses assuntos nesse momento. ${ }^{44}$ A posterior ampliação do sentido da noção, permitiu a sua inclusão do país naquele imaginário a partir de $1875 .{ }^{45}$

Mónica Quijada (1998) revisa a trajetória da América Latina como denominação. Problematizando historicamente aqueles primeiros momentos nos quais se refere à região como América Latina, Quijada consegue determinar em contraste do já rastreado pelo uruguaio Arturo Ardao, que "América Latina” é uma invenção local que inicia nos raciocínios do colombiano José María Torres Caicedo em 1850. Vale a pena a menção pelo cenário desse debate como problema historiográfico. Nele acho que se expressam dois elementos importantes, que ao se repetir em vários outros cenários poderiam estar configurando duas caraterísticas do pensamento latino-americano, pelo menos, duas características da linha de raciocínios que estou tentando seguir.

Quijada inicia o seu argumento, questionando a interpretação do historiador John Leddy Phelan (1968) e o seu sucesso acadêmico. Segundo a historiadora argentina Quijada-, para o estadunidense -Phelan-, a denominação "América Latina" tinha sido um invento Francês, expressado por primeira vez em 1861 como parte de uma estratégia de expansão imperial gaulesa. Nas datas, os fatos rebatem suficientemente a interpretação do norte-americano: os escritos do colombiano José María Torres, estão datados em 1850, onze anos antes. Contudo, Quijada apresenta parte da genealogia construída por Phelan onde, ao parecer, aquela estratégia francesa de 1861 remontaria a 1836, quando o termo "América Latina" foi exposto por primeira vez por Michel Chevalier. Ainda a evidente antecedência, o sentido pelo qual Chevalier nomeou assim a região, não compartilha o seu uso no discurso dos intelectuais da região apos 1850. Para Chevalier, aquela denominação era uma forma de descrever a oposição cultural europeia que, segundo ele, tinha se reproduzido no Novo Continente: uma América germânica -na qual Chevalier incluía os Anglo-saxões- e uma América romana

\footnotetext{
${ }^{44}$ Alguns estudos deixam ver que a ideia de inclusão do Brasil naquele imaginário não foi tão simples de digerir nem tão estendida de aceitar. Martins (2012) menciona como para alguns intelectuais, como Germán Arciniegas ainda anos 1940, a ex-colônia portuguesa era mais parecida com o Canadá que com os países da região. Da mesma forma, como no caso de alguns outros países da região, para vários intelectuais brasileiros o projeto bolivariano não era exatamente desejável.

450 colombiano Arciniegas escreveu em 1949 "los indoespañoles vivimos dándole la espalda al Brasil. Ni su literatura, ni su historia, ni su arte nos son familiares. Seguimos interesándonos más por los casos de España que por las de nuestro gran vecino del sur. La propia semejanza de las dos lenguas nos aleja. Nadie estudia portugués porque es demasiado fácil. Nadie lo lee, está fuera de las líneas de menor resistencia. En el fondo, porque es difícil. Los mismos argumentos explican la actitud de recíproca indiferencia que en este caso mantiene el Brasil" (Martins, 2012, p. 97).
} 
[...] ambas ramas -la latina y la germana- se habían "reproducido" en América. Como la Europa meridional, Sud América era "latina" y "católica"; la América del Norte, por el contrario, era "protestante" y

"anglosajona" (Quijada, 1998, p. 599).

Por sua parte, o uso do nome América Latina proposto por Torres, respondia à conformação dos princípios da unidade, como um mecanismo para que os países da região se protegessem do assédio dos Estados Unidos. Vários líderes e grupos de intelectuais da época concordavam com o espirito dessa ideia. ${ }^{46}$

3.

Não acredito que seja descabido pensar que aquela denominação construída pelo francês -Chevalier- não só pudesse chegar nos ouvidos dos intelectuais da região, senão que fosse reelaborada ao contraluz dos fatos que aconteciam na região, criando um novo sentido. Essa prática de tomar ideias de outros cenários culturais -sobretudo europeusé uma constante na maneira como muitos latino-americanos tinham construído a sua relação com a realidade. Talvez, quem tenha conceituado melhor essa forma de proceder tenha sido o brasileiro Oswald de Andrade no seu famoso Manifesto Antropófago de 1928 e, talvez, a prática que significa, possa determinar uma dessas tentativas características do pensamento latino-americano que anunciei alguns parágrafos atrás.

A seguinte característica, está relacionada com o chamado circunstancialismo, prática que pode ser rastreada em camadas de intelectuais da região desde o próprio século 18, se me deixo levar pela tentação de fazer regressões consecutivas, como as chamaria Pierre Bourdieu (2010). A defesa das circunstancias estimulou -e talvez ainda o faz- a leitura crítica do que vem de longe, posto em contraste com aquilo que acontece na realidade dos intelectuais da região. Palavras mais, palavras menos, e para dizê-lo assim sem imposições teóricas impostas a priori, mas compreendendo os fatos no seu contexto e conceituando-os posteriormente, como um esforço por compreender densamente as circunstâncias. ${ }^{47}$

\footnotetext{
46 “Un Congreso de Plenipotenciarios, que afianze la independencia nacional de las diferentes Repúblicas i que se uniforme en el reconocimiento de los principios de derechos internacional. Que adopten el mismo sistema monetario i el de pesos, pesas i medidas oficiales; que se establezca un plan uniforme de correspondencia postal" Tomás Cipriano de Mosquera (Colômbia) em 1863 (Pabón, 2012, p. 30). Mosquera menciona isso sendo o primeiro presidente dos Estados Unidos de Colômbia, denominação politica vigente entre 1863 e 1886.

47 Não fora do assunto, desde um ponto de vista geográfico: 'nenhum estrangeiro tem como dizer nada dos assuntos que acontecem no território no qual nasci'. Não deixa de ser uma ilusão. As categorias com as que
} 
América Latina é um desenho que permite pensar nos elementos próprios por meio das diferenças com os outros, como um mecanismo para proteger a soberania e a autonomia das novas repúblicas.

\section{O povo como nação}

[...] Pero en ausencia de esa índole perfectamente diferenciada y autonómica, tenemos -los americanos latinos- una herencia de raza, una gran tradición étnica que mantener, un vínculo sagrado que nos une a inmortales páginas de la historia, confiando a nuestro honor su continuación en lo futuro. El cosmopolitismo, que hemos de acatar como una irresistible necesidad de nuestra formación, no excluye, ni ese sentimiento de fidelidad a lo pasado, ni la fuerza directriz y plasmante con que debe el genio de la raza imponerse en la refundición de los elementos que constituirán al americano definitivo del futuro. José Enrique Rodó (Uruguai) em 1900 (Rodó, 1976, p. 35).

1.

Na carta de intenção assinada pelos primeiros latino-americanos que deram início ao processo da ALADI em 1978, não é possível determinar exatamente a que caraterísticas que os autores se referem quando mencionam as coincidências da vida rural na América Latina. Porém, no discurso os autores conseguiram vinculá-las com a pobreza, a falta de educação, as carências de oportunidades de trabalho produtivo, o desconhecimento da ciência e a tecnologia, a desnutrição, os problemas de saúde, a ignorância e até a destruição de valores tradicionais locais (Polo, et al., 1978a). Como características, elas parecem ser o reflexo de algumas olhares sobre a América Latina chamada do "pesadelo" por Elizabeth Cancelli (2003) a partir das ideias construídas por intelectuais regionais dos séculos 19 e 20.

Cancelli expõe as concepções de intelectuais sobre América Latina a partir de algumas ideias apresentadas em determinados documentos. 0 texto usado no caso de Eduardo Prado, foi publicado em 1893, o de Manoel Bomfim em 1905, o de Paulo Prado

se constroem, criticam e resolvem essas realidades, na grande maioria dos casos dos latino-americanos são categorias impostas nas epistemologias externas. Muito apesar da vindicação e o trabalho pela tradução, como enfoque, aquelas categorias escolhem elementos para ser observados enquanto excluem outros. Vários tinham se perguntado sobre isso. Me parece que a ideia de Walter Mignolo, ainda restringido ao problema das negritudes, recolhe o sentido da ironia "no se trata pues de un "privilégio epistémico" sino del derecho que tienen los intelectuales y activistas negros de no continuar siendo hablados y representados por honestos intelectuales blancos" (Mignolo, 2009, p. 262). 
entre 1926 e 1928 e o de Oswald de Andrade em 1953. Ainda esta linha de autores pode demostrar o que achavam alguns brasileiros sobre a América Latina, pelo menos o aparecimento de algumas dessas ideias no discurso de 'nossos latino-americanos' no México, parece entregar verossimilitude à ideia de Cancelli de apresenta-los como versões da América Latina

[...] El espíritu norteamericano es un espíritu de violencia. El espíritu de las razas meridionales transmitido a los brasileños aunque más o menos viciado a través de los siglos y de las diversas amalgamas del iberismo, es un espíritu jurídico [...] que conserva siempre cierto respeto a la vida y a la libertad del hombre. Eduardo Prado (Brasil) em 1893 (Cancelli, 2003, p. 64).

Agora, não digo que nossos latino-americanos reunidos no México tivessem uma influência consciente da corrente de pensamento desses brasileiros. O que estou tentando mostrar é um lugar onde aquelas ideias gerais sobre a região estão fazendo eco. Uma certa qualidade de ideias em movimentação desde vários anos antes -pelo menos oitenta- daquele Interdesign no México em 1978. Parece-me que isso ajuda no desmonte de tantos determinismos que pretendem explicar a epistemologia do design na região como um reflexo de iniciativas europeias.

2.

As ideias da América Latina vista como um pesadelo pareciam estar alinhadas aos acontecimentos materiais da modernização urbana e social da região. Na medida em que as sociedades se tornavam cada vez mais complexas, mais evidenciavam os seus problemas sociais, aqueles que tanto preocupava determinados grupos de intelectuais da região desde o tempo da colônia e que gravitavam em torno da pobreza e da miséria.

Expus anteriormente como um dos princípios daqueles projetos unionistas dependia da configuração de uma identidade regional. Seguindo Cancelli, é possível afirmar que, em geral, uma das estratégias para conseguir o estabelecimento dessa identidade, baseava-se na comparação entre nós e os outros; eles mais ou menos formulados como inimigos -no sentido ideológico-, enquanto nós, como possuidores da verdade. É uma estratégia mais ou menos esperada na formação do pensamento ideológico. Sempre é ilustrativa a forma como -entre outras coisas- Manheim explica esse procedimento a partir de alguns trechos do evangelho de João (Manheim, 1987). 
A comparação acaba por ser eficiente na possibilidade de fortalecer o nosso, o que leva a um essencialismo. Para determinados intelectuais da região na virada do século 19 -como por exemplo Eduardo Prado-, o pensamento republicano que representa o olhar estadunidense, exibe perversões no exercício do poder, que redundariam no que ele chamava de aventureirismo. Por sua conta, o pensamento império-Brasil -ampliado por Cancelli para Latino-americano- está caracterizado por ser sereno, normativo e de grande sentido aglutinador. A ideia de Prado é uma apologia à conformação da identidade por meio de uma certa obediência à corporificação do poder e aos sentidos que o catolicismo implanta na cabeça dos integrantes da nação. Com as variações necessárias, esse princípio pode se sentir no esquema político-social com que vários países da região iniciam o século 20.48

Há duas ideias que gostaria ligar neste ponto. Segundo Cancelli, enquanto a América do Norte procurava os legados da liberdade, da cidadania e do direito, a América Latina esteve atolada e comprometida com os ideais revolucionários das lutas pela libertação, procurando a sua vez o direito à vida e o fim da privação e do medo. ${ }^{49}$ Entre várias outras coisas, o procurou a partir da construção de projetos nacionalistas regionais.

Por sua parte, se Hobsbawm (2010) tem razão, esse processo de configuração do nacionalismo passou por três momentos na América Latina até pelo menos a metade do século 20. Um primeiro -pós independência- embasado em uma retórica patriótica, a qual foi somada à busca pelos elementos de identidade apoiada em um relativo resgate das imagens culturais do mundo pré-colombiano, com o propósito de diferenciar e separar os crioulos da recentemente expulsada raça ibérica. ${ }^{50}$

\footnotetext{
${ }^{48}$ É conveniente lembrar o que vários tinham assinalado como características das republicas regionais nos seus primeiros 40 ou 50 anos de existência. Nas suas próprias proporções e diferenças em teses, para Ayerbe (2012), Scarfi (2013) e até Williamson (2009), Anderson (1993) e/ou Hobsbawm (2013) essas repúblicas do século 19, são independentes no politico, submetidas economicamente a Grande Bretanha primeiro, e logo depois aos Estados Unidos e -como é notório na ideia de Prado- conservadoras no social.

49 "trataba de establecer apenas la condición para la libertad sin que esto implicara el logro de la libertad propiamente dicha" (Cancelli, 2003, p. 60). A busca pelos direitos civis nas ideias de Hannah Arendt, afirma.

${ }^{50}$ As contradições não pareciam muito importantes na estratégia "Do ponto de vista cultural e político, as elites crioulas na América haviam sempre se identificado com os espanhóis e nutrido consideráveis preconceitos em relação aos índios. Não obstante, na iminência do rompimento com a metrópole, viram-se diante da necessidade de construir um discurso patriótico e identitário, por meio do qual deviam-se apresentar de forma distinta e em oposição aos espanhóis. Era necessário enaltecer à América, buscando unificar as populações em torno de valores, histórias e ideias comuns [...] A retórica nacionalista dos
} 
3.

Um segundo momento desse nacionalismo proposto por Hobsbawm, está relacionado com as elites locais fazendo coincidir a construção da Nação com os ideais do progresso a partir do desenvolvimento econômico e o estabelecimento de um poder central no território. Nesse momento, as elites começaram a se distanciar visivelmente das massas, procurando inserir um projeto progressista por todos os caminhos possíveis, passando -se era necessário e como efetivamente aconteceu-, por cima de todo aquilo que o impedisse. Isso ultimo lhe deixou ver a certos intelectuais da região um elitismo que dificilmente digeria enquanto contrariamente ia-se fortalecendo. No processo ficavam óbvios os vínculos cada vez mais estreitos entre tais elites e o dono do modelo: o império.

O chamado reformismo conservador do que fala Adrian Górelik (2005) construía seu caminho em uma estranha mistura com paradigmas modernos. Vários paradoxos se produziram, um deles o olhar pejorativo sobre o 'costumbrista'. Isso pode explicar porque em alguns países da região o elitismo suprimiu as imagens populares com os custos que tal coisa engendrava: exclusão política e econômica: "sólo aquellos comprometidos con el progreso o los que por lo menos lo aceptaban podrían ser considerados como los verdaderos miembros de la nación" (Hobsbawm, 2010, p. 317).

O terceiro momento proposto por Hobsbawm para o nacionalismo da região foi marcado pela Revolução mexicana e os ecos da Revolução russa. Estes movimentos criaram consciências nacionalistas embasadas no povo, ajustando-se gradualmente à complexidade social do percorrido do século, como recolhendo as experiências e os acontecimentos

[...] Eran nacionalistas en el sentido de ser [...] fundamentalmente antiimperialistas y estabelecer al "pueblo" como el objetivo básico de la acción política [...] lo que tenían en común [o movimento estudiantil argentino de 1918, o indigenismo peruano dos anos 1920 e a "brasilianidad" depois dos anos 1930] era la extensión del concepto de "nación", [incluindo] a las masas de sus habitantes (Hobsbawm, 2010, pp. 317-318).

Naquele reformismo conservador a elite tinha excluído das suas imagens nacionais todo aquele que não permitia a conquista dos ideais do avanço e do desenvolvimento

crioulos iria, então, especialmente no México e no Perú, exaltar seus passados pré-hispânicos, buscando neles as origens das identidades nacionais dos Estados em construção" (Almeida, 2001, p. 114). 
econômico: eles eram obstáculos do progresso. ${ }^{51}$ As diferentes estratégias que a elite usou são conhecidas em toda a região ao passo em que a sociedade se adensava e se tornava mais complexa. Cada uma construindo uma certa consciência em críticos políticos e intelectuais regionais que -sem muitas variações- seguiam pensando e fortalecendo a ideia da libertação como caminho para a resolução dos problemas sociais da América Latina do pesadelo. ${ }^{52}$

Se o abandono dessa América Latina cheia de problemas sociais era incompreensível para uma corrente de intelectuais latino-americanos, por sua parte os modelos que situavam os problemas sociais no coração do desenvolvimento eram mais do que bem-vindos. Estes modelos tinham uma alta carga nacionalista, na qual era fortalecida a relação entre 'a raça' e o território, como meio para a solução do pesadelo. Os costumes, as tradições. Os produtos e as essências do povo. A ideia se tornava redundante quando estabelecia o princípio de que nenhum forasteiro pode dar resposta às carências de nossos povos: "una raza capaz de vencer los desafios de lo Nuevo, sea en el sentido de un recomienzo para una civilización proscrita de Europa, sea en el sentido de lo nuevo como un Nuevo Mundo, nuevo como en una utopia" (Cancelli, 2003, p. 60). De alguma maneira, os sentimentos e os sentidos construídos por esses intelectuais durante o século 19, encontrariam nas ideias revolucionarias comunistas uma fonte para atualizar seu discurso no século 20.

Ao sentido reivindicatório da solução dos problemas sociais era somado um sentimento que considerava que a nação estava formada pelo povo, materializado em movimentos democráticos inspirados em Moscou (Hobsbawm, 2010). Um povo que os projetos de construção nacional das elites tinha deixado de lado, sobretudo quando o Estado intervencionista se projetou como uma vanguarda, em reflexo dos experimentos

\footnotetext{
51 Como se fosse cumprida a ideia de Stuart Hall "a cultura popular tem sido há tanto tempo associada às questões da tradição e das formas tradicionais de vida -e o motivo por que seu "tradicionalismo" tem sido tão frequentemente mal interpretado como produto de um impulso meramente conservador, retrógrado e anacrônico. Luta e resistência -mas também, naturalmente, apropriação e expropriação-" (Hall, 2008, p. 232).

52 Nas décadas dos anos quarentas, cinquentas e sobre tudo sessentas do século 20, além da miséria e a pobreza, a massa crítica do desenvolvimento, tinha agregado o elitismo das burguesias nacionais e a sua estreita relação com os Estados Unidos à ideia do pesadelo. Muitas destas ideias outorgadas pela crítica comunista na região. De fato, para lembrá-lo, a facção heterodoxa do comunismo até explicava os elementos relacionados com esse pesadelo, quando denunciava que a elite vinha participando do processo de drenagem da América Latina, perpetuando o seu subdesenvolvimento desde o século 16.
} 
dos Estados Unidos. ${ }^{53}$ Esses movimentos, além da inclusão do povo no centro da consolidação nacional, eram fundamentalmente anti-imperialistas, o que se combinou organicamente com aquela corrente nacionalista de intelectuais que galopava na região desde o século 19

[...] Somos a Utopia realizada, bem ou mal, em face do utilitarismo mercenário e mecânico do Norte. Somos a Caravela que ancorou no paraíso ou na desgraça da selva, somos a Bandeira estacada na fazenda. O que precisamos é nos identificar e consolidar nossos perdidos contornos psíquicos, morais e históricos. Oswald de Andrade (Brasil) em 1953 (Andrade, 1978, p. 153).

Enquanto a revolução do capital ia mostrando o seu avanço na América Latina, os diversos intelectuais da região reforçados pelas ideias daquele nacionalismo, assinalavam as suas perversões e vazios, denunciando a dependência técnica, econômica e cultural que nossos países tinham estabelecido com o império. Para alguns era a constatação de um projeto de desenvolvimento afastado do povo. Aqueles intelectuais seguiam sonhando com a revolução como caminho para consolidar o direito à vida... o fim da privação e do medo. 0 sucesso de Fidel Castro e de Che Guevara em 1959 deu o impulso para que tais ideias fortaleceram-se nos imaginários dos jovens intelectuais dos anos 1960 e 1970

[...] El principal enemigo era la burguesía que, lejos de tener intereses opuestos al imperialismo estadounidense, se identificaba básicamente con este último y funcionaba como agente local del capital monopolista norteamericano e internacional. Además, existían condiciones objetivas para llevar a cabo con éxito una revolución, y su objetivo imediato era el socialismo (Hobsbawm, 2011, p. 361). ${ }^{54}$

Se o espectro do capitalismo e o imperialismo rondavam a região e tomavam formas materiais no ritmo das mudanças sociais na América Latina, a antiga esperança da libertação oitocentista -com as suas proporções claro- adquiria novas formas e forças a partir do triunfo da Revolução em Cuba.

\footnotetext{
${ }^{53} \mathrm{Na}$ ilusão de complemento entre o Centro y a Periferia as sociedades latino-americanas no perceberam que serviam "de reflexo invertido ao êxito norte-americano do Estilo Internacional" (Arantes, 2001, p. 110), quando por exemplo se fala de arquitetura.

${ }^{54}$ Sempre pode ser ilustrativo o mote de Jaime Jaramillo Uribe "en América Latina, especialmente en los medios juveniles y estudiantiles [...] se expandió el culto a dos figuras dirigentes, Fidel Castro [y] -el Ché Guevara-. Los estudiantes de mi generación que militábamos en la izquierda teníamos en nuestros cuartos un retrato de Lenin. Los de la década del sesenta tenían uno o varios de la romántica figura del Che Guevara" (Jaramillo, 2007, p. 167).
} 


\section{"O tamanho da nossa solidão"}

1.

Está visto que um crescente pensamento anti-imperialista respirava na base das características mencionadas. Diferente do que parecia pensar Hobsbawm, aquele antiimperialismo atravessou as décadas e as fases que ele propôs, não sendo parte de apenas uma delas. Aquele pensamento, na cabeça de determinados intelectuais viam os estrangeiros com interesses colonialistas como um perigo. Como uma ameaça à autonomia

[...] El peligro yanqui [...] la politica exterior de los Estados Unidos tiende a hacer de la América Latina una dependencia y extender su dominación [...] Nadie ha olvidado que el território mexicano de Texas pasó a poder de los Estados Unidos después de una guerra injusta [...] no tengamos vocación de tropa colonial. Iberoamérica para los ibero americanos. Manuel Ugarte (Argentina) em 1901 (Ugarte, 1976, p. XVIII).

Dada a projeção internacional que adquirem os estadunidenses durante o século 20, aquela ameaça foi incrementada. Em plena Guerra Fria, as operações estadunidenses na América Latina na metade do século, exibem evidentes interesses coloniais, para o olhar de vários intelectuais latino-americanos. Ayerbe apresenta vários dos assaltos estadunidenses à autonomia de alguns países latino-americanos naquele momento

[...] La política exterior de "puertas abiertas" de la administración Truman atribuye al nacionalismo la principal responsabilidad por las crisis económicas, guerras y revoluciones de la primera mitad del siglo XX (Ayerbe, 2012, p. 83).

Claro, para quem expande a liberdade em 'nome da América', qualquer esforço por recriar o Mito de Origem é pouco, como irreverente reflexiona Azevedo (2008), e qualquer reivindicação da diferença -nesse caso estimulada pelo nacionalismo- era motivo de agressão.

Os estadunidenses não estavam muito convencidos em apoiar a região com seu desenvolvimento, argumentando que, de fato, a região deveria seguir com seu papel de provedora de matérias primas, respeitando o grande esquema da Divisão Internacional do Trabalho. Dadas as diversas conjunturas da década dos anos 1950, que culminam com a Revolução em Cuba, os Estados Unidos decidem mudar de parecer.

Azevedo apresenta uma clara cronologia que permite ver como um dos projetos bandeira do recém-eleito presidente Kennedy, se concretiza para a região: A Aliança para o Progresso: "uma reedição em escala reduzida do Plano Marshall (plano para 
recuperação europeia na pós-guerra)" (Azevedo, 2008, p. 291). Mas isso aconteceria como 'solução' norte-americana a partir de 1961. Anos antes, os Estados Unidos já estavam preocupados com o nacionalismo presente nos regimes políticos como o de Getúlio Vargas no Brasil, sobretudo, pelo que percebiam como proximidade com o fascismo e o comunismo. Poderia dizer que o nível de paranoia fica claro na invasão estadunidense na Guatemala em 1954, dada a ameaça dos interesses da United Fruit Company (Ayerbe, 2012).

Se essas percepções misturadas com o aquele expansivo espírito capitalista engendrou a invasão da Guatemala, a cordura parece em risco total quando Fidel Castro anuncia o triunfo da Revolução, cinco anos depois. A mudança na política norteamericana com a região evidenciava mais uma vez a sua ansiedade. E em seguida, a relativa tranquilidade que significava para eles a ascensão do regime militar no Brasil em 1964. ${ }^{55}$ Logo depois chega a ocupação da República Dominicana pelos Estados Unidos, os golpes militares na Argentina e no Chile, entre outros.

A região parece ser bombardeada pelos interesses estadunidenses, mobilizados angustiadamente pelos países latino-americanos nos mais diversos formatos: desde os programas de cooperação técnica, até a ocupação. Para aqueles que acreditavam na autonomia como caminho de realização, todos esse eventos eram assaltos aos princípios da vida e da soberania.

Parece-me que a denúncia feita por Oswaldo Guayasamín na sua série Reunión en el Pentágono é eloquente. 0 delirante aspecto daquele primeiro membro da série -que seria o que está sentado no extremo esquerdo daquela mesa sugerida por Guayasamín-, lembra a sua referência de mãos que matam pelas costas: "el alemán, con una mano que, a más de tocar maravillosamente el piano, con la matemática de la muerte sabe como se puede matar a millones de personas" (Efraim, 2014, p. slide 40). A série é uma representação de como uma linha de intelectuais observava o que acontecia na região. É uma caricatura do terror e da violência em clara ligação com os Estados Unidos. 0 Pentágono que os convocava, era o lugar aonde se decidia os passos porvir. Operações

\footnotetext{
55 "la revolución de abril también sobrevino como un choque para Fidel Castro y es evidente, por sus propias declaraciones, que él consideró el hecho como un grave pérdida para Cuba. En Brasil, los primeros tres meses del gobierno de Humberto Castello Branco tuvieron éxito [...] ha ejercido hasta ahora un liderazgo firme, responsable, ejecutivo, y su régimen se basó en promover un inicio promisorio en el sentido de aliviar algunos de los graves problemas económicos y sociales del Brasil. El apoyo popular al régimen se mantiene relativamente alto" Trecho de um relatório da CIA chamado Effects of the Brazilian Revolution (Ayerbe, 2012, p. 158).
} 
estadunidenses estão presentes na obra de Guayasamín no formato de denúncia. Desde a sua interpretação de "Bahia Cochinos", na tela que leva esse nome, até as alusões da CIA e o Pentágono. Uma eloquente associação com o imperialismo, visto como a morte. ${ }^{56}$
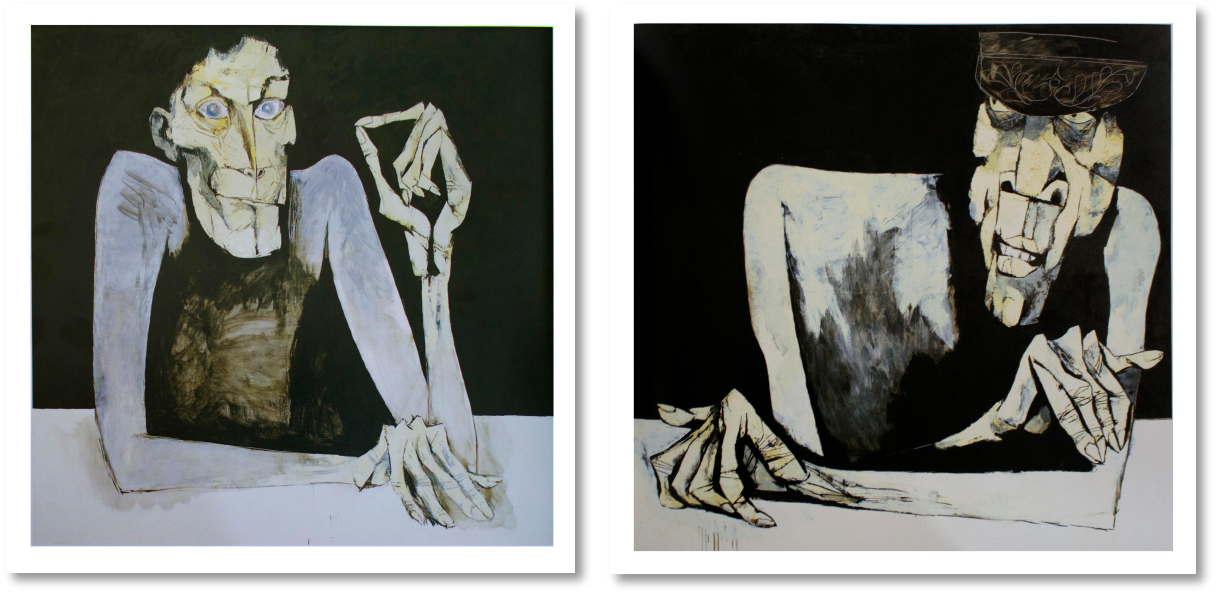

Figura 1. Esquerda Reunión en el Pentágono I. Direita Reunión en el Pentágono V. 1970 Oswaldo Guayasamín (Equador). 1,79m x 1,79 m Imagens de Kirby \& Keeble, 2014

Um profundo sentimento antiyankee percorria a região durante os anos 1960 e 1970. Dada a confrontação que significava para o momento, a retórica dos líderes cubanos dos anos 1960, estava localizada na cúspide

[...] Este es un pueblo [cubano] en el que hace pocos años los marineros norteamericanos hacían sus necesidades en la cabeza de nuestro apóstol Martí, y hoy es un pueblo enteramente erguido contra el imperialismo norteamericano [...] nosotros estamos directamente colocados contra el imperialismo yanqui, en que nos amenaza todos los días, en el que es patente su agresividad. Ernesto 'Che' Guevara (Argentina-Cuba) em 1963. (Guevara, 1970, pp. 15-16).

2.

Já mencionei como o temor da perda da soberania e da autonomia fez com que vários intelectuais da região sonhassem com a ideia de uma grande região 'unificada' que os protegessem enquanto determinam as qualidades daquilo que os ameaça. Um típico maniqueísmo, próprio dos mecanismos com os quais se constroem comunidades desde a exaltação 'do nosso', em diálogo com o perigo que representa o inimigo que nos

\footnotetext{
56 Em 1973, Guayasamín pinta "Lágrimas de sangre", um expressivo homenagem a Salvador Allende, Victor Jara e Pablo Neruda. A obra pode ser lida como uma denúncia daquele terror anunciado na série anterior, misturado com grande assombro e estupefação. Me parece que a coletânea organizada da obra do equatoriano em dialogo com trechos de obras de Neruda é ilustrativa. Ver Kirby \& Keeble (2014).
} 
assedia. Esse exercício maniqueísta apresentou-se em diferentes formatos na produção de intelectuais latino-americanos. Da retórica poética mais elaborada, até a vulgarização -não de modo pejorativo- dentro da chamada cultura pop logo após os anos 1960. Assim, poemas que seguramente respondem às expectativas estilísticas do romanticismo no século 19 tiveram o seu espírito -não tanto a sua forma- atualizado nas letras de diversas músicas dos anos 1970.

As ameaças à democracia e a repressão cotidiana aos habitantes de vários países da região, eram -entre vários outros aspectos- evidências do assédio norte-americano no território. Em uma sentida fala no seu discurso de recebimento do Nobel de literatura em 1971, Pablo Neruda fez a plateia percorrer territórios, povoados, costumes e sentidos culturais de um Chile presumivelmente afastado da modernização. Neruda destaca o contraste entre o nosso -puro, ancestral, livre- e o forasteiro -colonialista e promotor da dependência-

[...] Heredamos la vida lacerada de los pueblos que arrastran un castigo de siglos, pueblos los más edénicos, los más puros, que construyeron con piedras y metales torres milagrosas, alhajas de fulgor deslumbrante: pueblos que de pronto fueron arrasados y enmudecidos por las épocas terribles del colonialismo que aún existe. Pablo Neruda (Chile). Discurso de recebimento do prémio Nobel em literatura em 1971 (Neruda, 2014).

Um colonialismo que permitiu -ou obrigou- encontrar aquilo que é nacional... isso que é nosso. Caos e primitivismo -ideias pejorativas que triunfavam na luta de preconceitos de determinadas camadas sociais na América Latina- são relativizadas em contraste com o orgulho. No final, América Latina se tornou a utopia realizada... o paraíso aonde ancorou a Caravela perdida da que falava Oswald de Andrade

[...] América feliz, en la clemencia de su clima, en el esplendor de este cielo, inteligente, laboriosa y pacífica en la comunión social, bondadosa y fraternal en la expansión natural de la instintiva cordialidad, apartada de los egoísmos feroces que envilecen a otras civilizaciones. Manoel Bomfim (Brasil) em 1903. (Cancelli, 2003, p. 70).

[...] Por los caminos de Europa encontre el país de América que yo había dejado y en el que había vivido casi extraño y ausente. Europa me reveló hasta qué punto pertenecía yo a un mundo primitivo y caótico; y al mismo tiempo, me impuso, me esclareció el deber de una tarea americana. Juan Carlos Mairátegui (Perú) 1923-29. (Cancelli, 2003, p. 57).

Nessa lógica somos indígenas e somos negros; somos camponeses e caipiras. Somos uma raça mestiça... um povo híbrido. Uma linha desse sentido vai se reconhecer 
nas ligações com os habitantes do território antes da chegada 'dos intrusos' europeus no século 15. Vários tipos de obras reivindicam essa tese. Parece ser abordado em determinados momentos na obra do pintor peruano José Sabogal (1888-1956), do mexicano David Siqueiros (1894-1974), do equatoriano Camilo Egás (1889-1962), ou do seu colega Oswaldo Guayasamin (1919-1999). Entre outros tantos, em vários dos seus trabalhos, eles exploram a linguagem moderna na expressão artística de determinadas vanguardas -em geral expressionismo- na desculpa da reivindicação do indígena. No final, como diz García-Canclini (2015) que diz Ortiz sob Andrade: ser nacional era ser moderno.
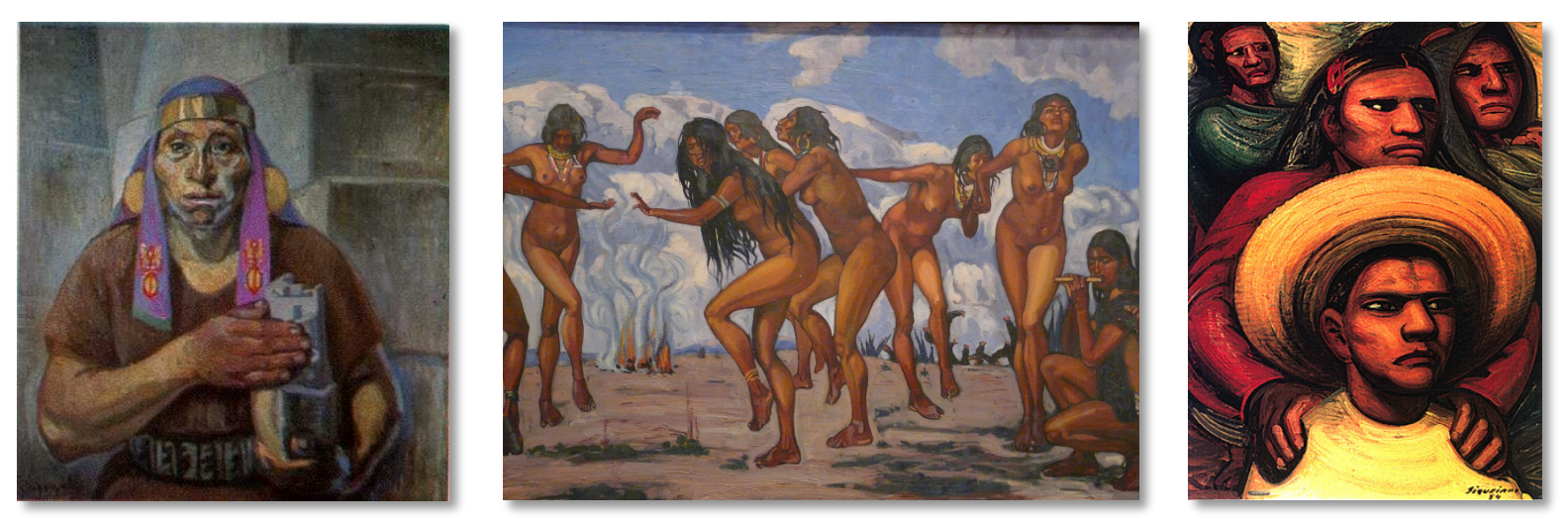

Figura 2. Esquerda, Arquitecto Quechua, 1923. José Sabogal (Perú) Centro, Danza Ceremonial, 1923. Camilo Egas (Equador) Direita, El Reto, 1954. David Siqueiros (México)

Mas, se as raízes indígenas dão um sentido sobre o orgulho nacional é claro que no trabalho de outros artistas da época foi encenada a presença da cultura afro, como no caso da brasileira Tarsila do Amaral (1886-1973), e do mestiço, como no caso dos cubanos Mario Carreño (1913-1999) e René Portocarrero (1912-1985). 

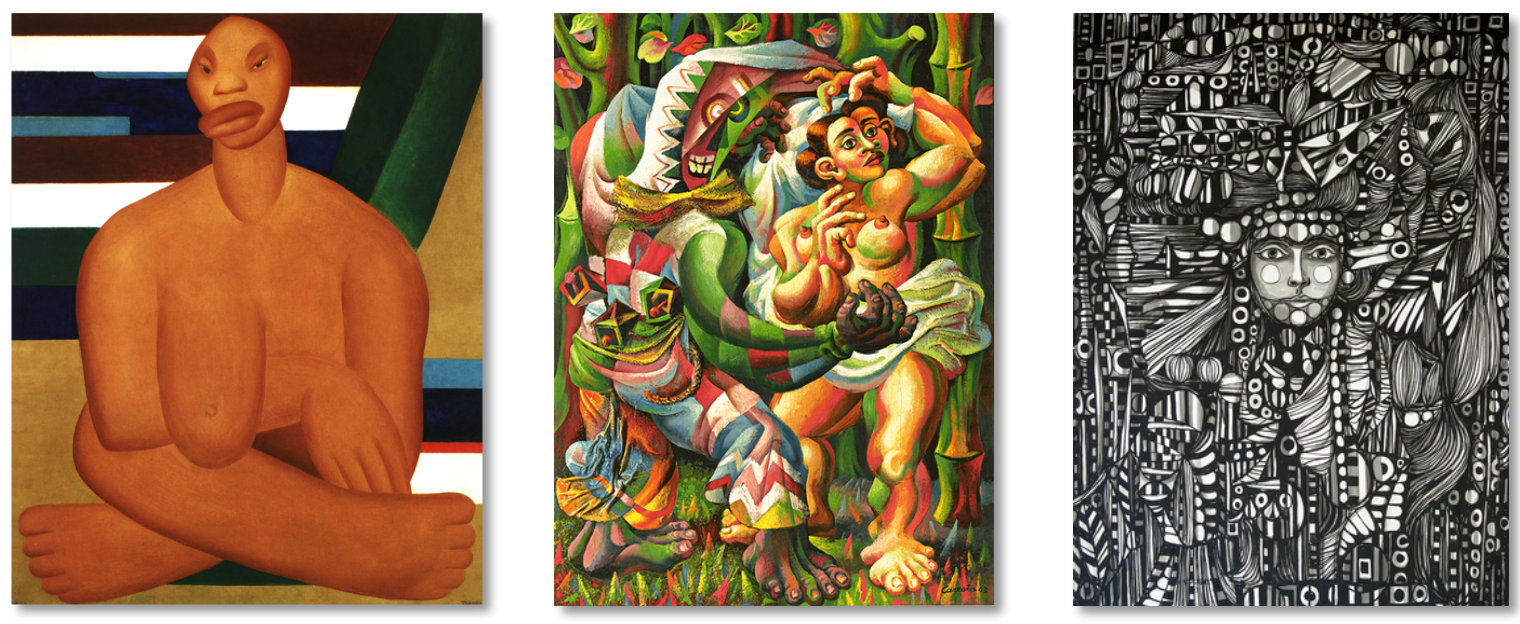

Figura 3. Esquerda, A Negra, 1923. Tarsila do Amaral (Brasil) Centro, Danza Afrocubana, 1943 Mario Carreño (Cuba)

Direita, Figura ornamentada con tocado de carnaval, 1963. René Portocarrero (Cuba)

Assim como aconteceu com as representações de camponeses, operários e canteiros, artesãos, etc., todos eles provenientes de camadas sociais que bem representavam aos costumes do povo e/ou mostrassem a pobreza. Por exemplo, as telas do cubano Carreño assim como as do equatoriano Egas, o brasileiro Vicente Monteiro (1899-1970) e até o mexicano José Clemente Orozco (1883-1949).
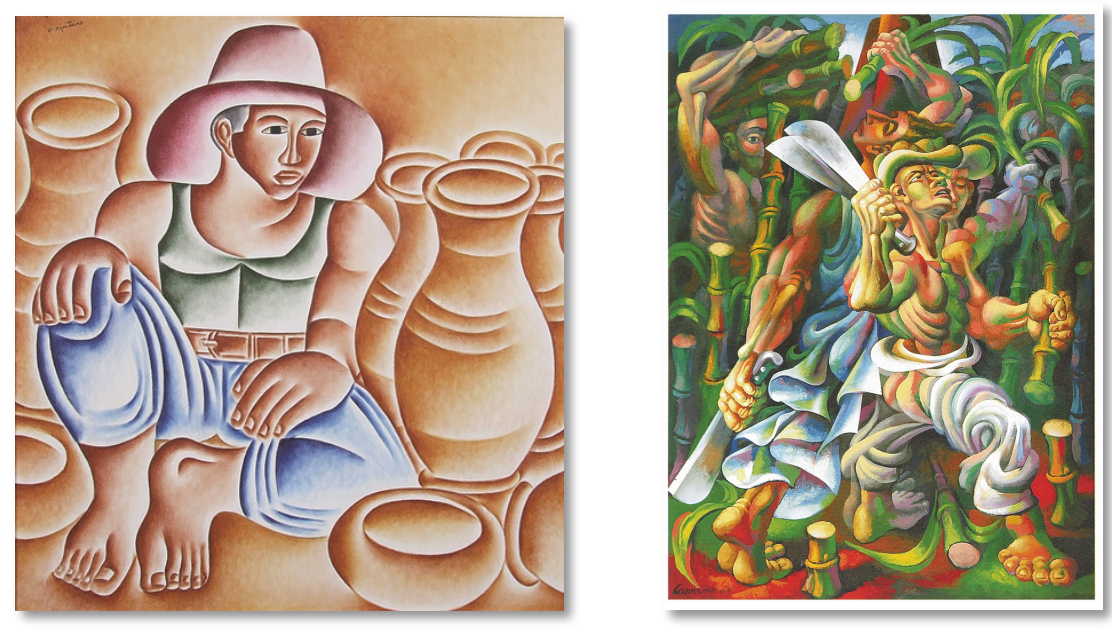

Figura 4. Esquerda. Artesão, 1930s. Vicente Monteiro (Brasil) Direita. Cortadores de caña, 1943. Mario Carreño (Cuba)

Todas essas qualidades e virtudes 'do nosso' relacionadas com a pureza e a verdade, projetadas no passado pré-colombiano, na mistura racial e/ou concentrada nos valores do povo. Do lado da exoticidade modernista mais global, no povo -na América Latina- repousava o exótico. Mas também estava significado nele tanto a ideia de nação, 
como -para lembrá-lo- a ideia de que nele estava concentrada a Igreja de Deus e portanto a verdade.

Uma clara intensidade e diversidade na circulação desses interesses na região. A grande maioria embasados em atualizações formais de vanguardas europeias apreendidas em viagens, estágios e amizades dos autores, mas traduzidas ou até interpretadas nas circunstâncias da nação, como reivindicações de alguns intelectuais do momento, como Pablo Neruda. No seu discurso de entrada na Faculdade de Filosofia e Educação da Universidade de Chile em março de 1962, ele propôs essa opção como caminho de resistência ao colonialismo

[...] En un país en que persisten todos los rasgos del colonialismo, en que la multitud de la cultura respira y transpira con poros europeos tanto en las artes plásticas como en la literatura, tiene que ser así. Todo intento de exaltación nacional es un proceso de rebeldía anticolonial y tiene que disgustar a las capas que tenaz e inconscientemente preservan la dependencia histórica (Neruda, 1971, p. 81).

\section{3.}

Outro elemento parece acompanhar essa busca dos elementos para configurar a essência da nação, uma reivindicação pela natureza das situações e a necessidade por resolvê-las conforme elas se apresentam. Um circunstancialismo, que já mencionei direta e indiretamente durante o texto.

Estabelecida inicialmente em torno da aposta política que devia nortear o processo de configuração das repúblicas, os dilemas são permanentes quando se supõe a importação de um modelo criado e implementado de fora. Guardando as proporções devidas, essa ideia parece respirar tanto na afirmação do brasileiro Eduardo Prado no início do século 20, assim como na reflexão do filósofo mexicano Leopoldo Zea, cinquenta anos depois dele

[...] Monárquico, Eduardo Prado era contundente al afirmar que tendríamos muchas "razones para odiar esta Constitución exótica (la republicana), copiada de una raza extraña (la norteamericana), sin raíces, ni antecedentes históricos entre nosotros (...) y que entrega la suerte de los Estados a tiranos locales". Eduardo Prado (Brasil) em 1904 (Cancelli, 2003, p. 62).

[...] La confusión y la dificultad se encontraban en el caos de las ideas importadas. "En política no; nuestro mundo de observación y aplicación está aquí (...) Apelar a la autoridad de los pensadores europeos es introducir la anarquía, la confusión, el embrollo en la solución de nuestras cuestiones". Leopoldo Zea (México) em 1953 (Cancelli, 2003, p. $56)$. 
No coração dessa preocupação claramente respirava a ideia de criar em função das circunstâncias que o contexto manifesta. 0 uso de modelos pré-fabricados fora dele significa um abuso. Em alguns textos dos anos 1950, o sacerdote colombiano Camilo Torres estava se perguntando o sentido do conhecimento científico e da técnica. Ele se perguntava se havia propósito em usá-los mesmo se não fossem orientados para a compreensão e satisfação das carências dos pobres e dos marginados do processo de modernização (Aguilera, 2002). O argentino Óscar Varsavsky, vinte anos depois, o expressa com veemência

[...] Se puede arrojar napalm en nombre de Cristo, se puede oprimir en nombre de Marx y se puede llegar al facsismo en nombre de la estatización de empresas, es una irresponsabilidad monstruosa seguirse guiando por etiquetas o esquemas teóricos que la realidad refuta una y otra vez. Oscar Varsawsky (Argentina) em 1975 (Roldán, 2010, p. 7).

É essa preocupação que esta motivando certamente a Pablo Robles naquele documento que compartilha com seus colegas em Interdesign 78. Mencionei trechos desse documento no capítulo 2. Só lembrarei aqui que Robles listou as 'competências' necessárias ao designer mexicano, todas elas voltadas para o conhecimento da realidade que o rodeia e as habilidades técnicas para mudá-la. Um diálogo entre aproximação crítica das condições em que moram as pessoas e a destreza para promover a que os outros possam conquistar o bem-estar. Um caminho para fugir daquilo que caracterizou como um grande inimigo: o assistencialismo, o voluntarismo e a descontextualização (Robles, 1978).

Essa preocupação presente nos diversos discursos e nos distintos formatos, também apareceu nas elaborações conceituais da crítica econômica e social de meados do século 20. Como demostrei, pode se afirmar que parte dos enunciados defendidos pelos intelectuais da CEPAL eram apoiados nesse circunstancialismo.

Como tinha mostrado, é possível ver como toda a reivindicação percorre os discursos elaborados de intelectuais e as suas obras, da mesma forma como vai se manifestando na chamada cultura pop. Só mencionarei uma música brasileira, que ao meu ver, deixa explícito o que estou tratando. Pretendendo uma exploração formal no estilo que já governava o sistema musical do rock internacional do momento, a banda paulista Secos \& Molhados incluiu uma música no seu álbum de estreia em 1973, chamada "Sangue Latino", nome que transpira essência e orgulho. Escrita por João Ricardo e Paulinho Mendoça, a música foi uma latente homenagem aos eventos que 
estão se desenrolando na região. A repressão às mais diversas formas de expressão, aos direitos civis, resistência e reivindicação da autonomia, todos como elementos que permitem pensar na identidade dessa grande comunidade imaginada. A alusão da incapacidade do Norte em compreender o que acontece, garantia do seu fracasso é também o assinalamento da sua impertinência. 0 orgulho daquilo desqualificado, por não ser bem visto, por não coincidir com o decoro... ao tempo um sinal de orgulho e um grito pela autonomia

\author{
Sangue latino \\ (Ricardo \& Mendoça, 1973) \\ Jurei mentiras e sigo sozinho \\ Assumo os pecados Uh! Uh! Uh! Uh! \\ Os ventos do norte não movem moinhos \\ E o que me resta é só um gemido \\ Minha vida, meus mortos, meus caminhos tortos \\ Meu Sangue Latino Uh! Uh! Uh! Uh! \\ Minh'alma cativa \\ Rompi tratados, traí os ritos \\ Quebrei a lança, lancei no espaço \\ Um grito, um desabafo \\ E o que me importa é não estar vencido \\ Minha vida, meus mortos, meus caminhos tortos \\ Meu Sangue Latino \\ Minh'alma cativa
}

4.

Conservadores, liberais, progressistas, comunistas e revolucionários. Dependendo do momento que se observe, nas proporções desse cenário e muito na própria forma de cada caso, todos eles defensores da autonomia latino-americana. ${ }^{57}$ As qualidades que representam os povoadores da região, ressonando, sendo amplificadas e por sua via

57 "El paso que va del intelectual comprometido al intelectual revolucionário puede traducirse en términos políticos como la diferencia entre reformismo y revolución. Las exigencias crecientes de participación revolucionaria devaluaron la nación de compromiso, bajo la cual gran parte de los intelectuales encontraron sombra y protección durante algún tiempo. Fue manifiesto el intento de redefinición del rol y la función social del intelectual, que al poner el acento en los requerimentos "revolucionários" (y no simplemente críticos, estéticos o científicos) de la práctica intelectual, afectó sus critério de legimitidad y validez" (Gilman, 1999, p. 83). 
fortalecidas na mais diversa quantidade e qualidade de expressões, dão vigência e intensificam a comunidade imaginada chamada "América Latina". Os diferentes ajustes nas circunstâncias durante esses quase 200 anos, mostram como o princípio que deu origem a essa imagem parece vigente até -pelo menos- o discurso dos fundadores da ALADI em Bogotá em 1980.

Um lugar comum cujos elementos de identificação cultural não parece necessário demostrar aos atores. A cotidianidade de cada indivíduo lhe permite afirmar que de fato existem dado o seu contato com a realidade. E o poder da imagem da Comunidade, lhe possibilita enxergar a esse mesmo indivíduo que se existe na sua própria realidade, deve se apresentar igual -o muito parecido- na realidade dos distintos 'irmãos', espalhados nos diversos cantos da América Latina. Se lembro aqui da carta que assinaram os designers latino-americanos no Interdesign 78 no México, essa lógica aflora com fidelidade

[...] La oportunidad de trabajar conjuntamente en el Interdesign'78 México nos ha permitido a los participantes latinoamericanos consolidar la consciencia de que los problemas de la región son comunes y de que las dificultades que afrontan el diseño y los diseñadores como herramientas del desarrollo de nuestros países son basicamente los mismos [...] finalmente [o estudo das problemáticas do workshop] pone en evidencia el hecho, no ciertamente casual, de que los problemas de los centros desarrollados no son los mismos de las zonas marginadas (Polo, et al., 1978a, pp. 1-2).

O nosso, igual entre nós e diferente do dos outros. 0 que lhes faz pensar que isso é assim? 0 que lhes permite acreditar que a sua experiência se reproduz nos diversos cantos dessa enorme região? Por uma parte me convenço de que uma forma de compreendê-lo está na configuração dos lugares comuns da crítica. A qualidade e por sua causa a diversidade dos formatos nos quais ela circulou, assegurou que as ideias se reproduzissem e chegassem aos mais diversos cantos da região. Um desses grandes imaginários é precisamente a ideia de que do Rio Grande até a Cabo de Hornos existe uma terra de nações soberanas e irmãs... de populações parecidas que compartilham os mesmos tipos de pesares. ${ }^{58}$

\footnotetext{
58 Quem visse os detalhes de como é que isso se dá, se convence também muito rápido de que a imagem é uma fantasia. Se é grande o desconhecimento que existe na região sobre a região, é gigantesca a ignorância que os habitantes de determinado lugar tem sobre as condições de outro, assim sejam vizinhos. 0 grande sintoma dessa gigante ignorância se manifesta no generalismo que pretende caracterizar os processos culturais da região dentro de uma enorme sacola. Uma abusiva hegemonização, que quiçá seja ao tempo
} 
Uma outra forma de compreender que eles tem essa ideia, se desenvolve precisamente desse ponto. Ao se configurar como unidade contra o inimigo, não importando tanto a heterogeneidade dessa massa que origina a ilusão de união, alguns elementos comuns se transformam em grandes qualidades fazendo das partes membros iguais. De um lado, se concretiza a ideia de união quando se entende que as ex-colônias espanholas compartilhavam a mesma historia de sangue, dor, luta e heroicidade, assim como o mesmo inimigo. De outro, se concretiza por meio de um grande aglutinador: a identidade linguística. Todas essas repúblicas falam espanhol, o que redefine as bordas do traço dessa Comunidade.

Além das contradições, e dos notórios paradoxos, a imagem do território se soma a essa ilusão, deixando pensar em que todos que moram dentro dos limites geográficos estabelecidos sejam filhos da mesma história e dos mesmos costumes, e portanto enxergam o mundo da mesma forma.

-Falamos a mesma língua e moramos no mesmo território-... -E o Brasil, que é tão enorme?-... -Bom, falamos a mesma base linguística, o português e o espanhol -em últimas, das línguas romances essas são as mais próximas- o que incluiria a sua cultura na Comunidade-.

Então, no final compartilhamos aquela base linguística, o mesmo território e, obviamente a mesma religião. Para uma sociedade conservadora no social -como Ayerbe caracteriza a conformação das republicas na América Latina- é uma tríade sublime, que sem dúvida permite pensar em que todos os que habitam da fronteira mexicana com os Estados Unidos até o Polo Sul, são seres humanos iguais

[...] Pero, mi patria, ¿es acaso el barrio en que vivo, la casa en que me alojo, la habitación en que duermo? ¿No tenemos más bandera que la sombra del campanario? Yo conservo fervorosamente el culto del país en que he nacido, pero mi patria superior es el conjunto de ideas, de recuerdos, de costumbres, de orientaciones y de esperanzas que los hombres del mismo origen, nacidos de la misma revolución, articulan en el mismo continente, con ayuda de la misma lengua. Manuel Ugarte (Argentina) em 1913 (Ugarte, 1976, p. 26).

uma evidência antropófaga. São procedimentos tipicamente Ocidentais de análises e classificação, aonde o diferente ao protocolo é igual e portanto não é digno de consideração. 
5.

É sintomático que para os fundadores da ALADI, várias dessas reivindicações estivessem presentes nos seus esforços de justificar a existência do design na região. Quando os designers latino-americanos no México afirmaram a existência de similaridades nos problemas que ameaçam nossos países, parece que, além de atualizar a corrente reivindicatória assinalada por causa da pobreza e a miséria, também estavam querendo delimitar um território fazendo valer a sua soberania. A identidade visual, projetada para o primeiro Congresso em Bogotá 1980, fortalece esse imaginário. Uma linha só percorre a forma do território; uma linha que consegue se fechar em cima, justamente na fronteira com o norte do continente... no Rio Grande.

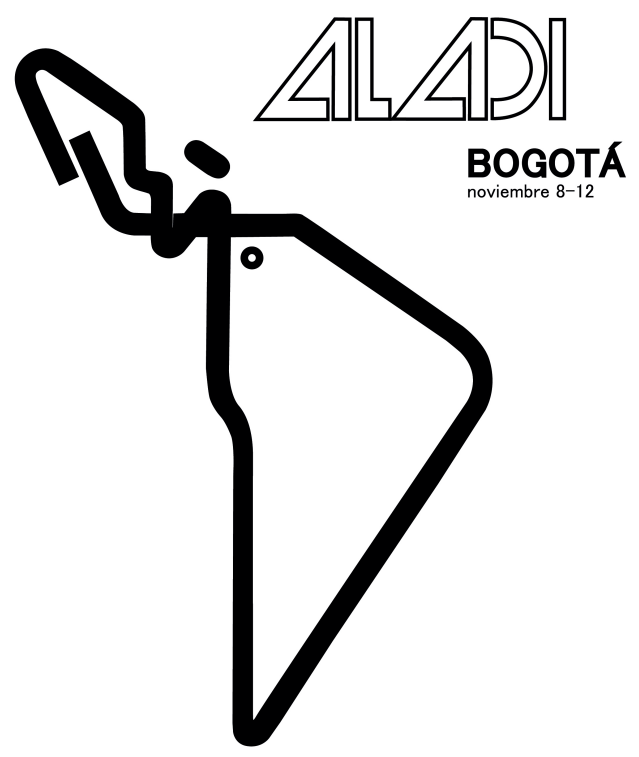

Figura 5. Identidade Visual para o primeiro congresso da ALADI. 1980. Autoria: Jesús Gámez (Colômbia)

Traçar o território como uma ação para desenhar a sua soberania. Uma soberania que permitisse que os integrantes dessa porção de terra resolverem as suas necessidades e configurarem a sua própria realidade. Se Anderson tem razão (1993), a identificação de um território é um dos princípios fundamentais na construção da identidade nacional. Dessa forma, considerando a preocupação com o assédio e com a defesa da autonomia, demarcar o território é um ato de reivindicação cultural.

Como as ideias mais gerais em vários latino-americanos, essa experimentação visual com o território tem antecedentes na região. Ainda que a grafia não corresponda plasticamente com a obra de Gámez, é famosa a peça de Joaquin Torres García “América 
Invertida". Para o que estou pretendendo, não importa tanto como Gámez parece inscrito no sistema formal da chamada "Escola Suíça” ou Torres García parece responder a um sistema visual, fugindo das suas próprias influências. ${ }^{59} \mathrm{~A}$ mim parece notório como Gámez fecha o território do assédio externo enquanto Torres García redefine o Sul geográfico como Norte conceitual na metáfora do lugar da visão, da inspiração e do porvir. A apologia de Schwartz é eloquente: "meu sul se converteu em meu norte" (Schwartz, 2013, p. 10), outorgando perspectiva histórica à peça de Gámez e sentido reivindicatório à sua motivação: "Minha vida, meus mortos, meus caminhos tortos" (Ricardo \& Mendoça, 1973).

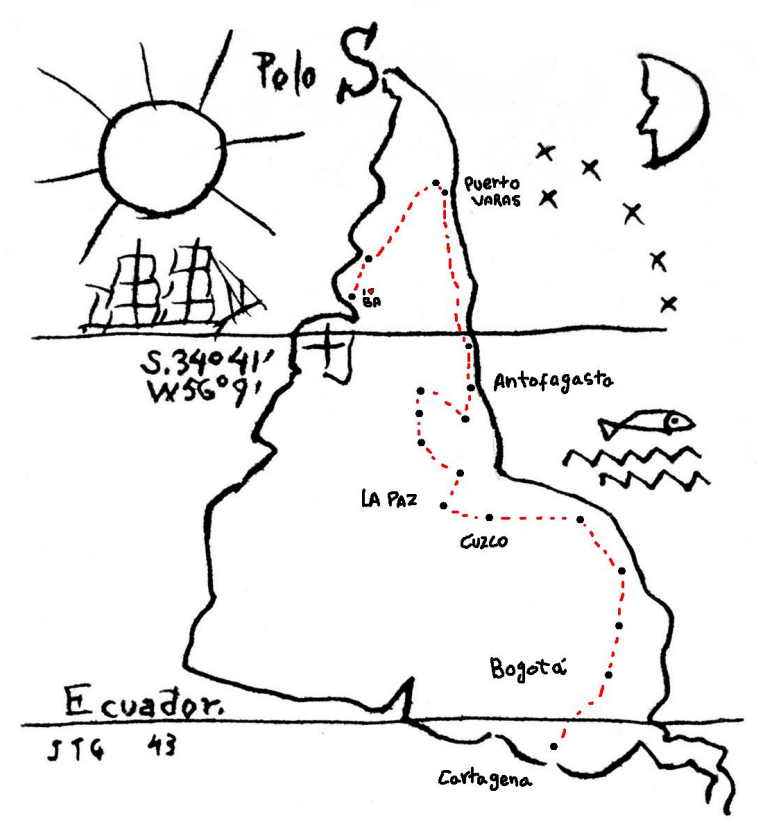

Figura 6. América Invertida, 1943. Joaquin Torres García (Uruguai)

6.

Em uma insistência no discurso visual, quando os brasileiros organizaram o terceiro congresso da ALADI e a sua terceira assembleia no Rio de Janeiro e Petrópolis respectivamente em 1984, uma língua foi acrescentada a esse território que já tinha sido

\footnotetext{
${ }^{59}$ Quem faz uma análise da linguagem da obra de Gámez encontrara determinados patrões e sínteses que deixam ver as claras influências com os postulados desse tipo de expressão visual. Agora, aquele que faz essa análise também vai encontrar as maneiras como esses princípios são interpretados por Gámez. Não são usados dentro de uma disciplinada liturgia. Eu escrevei um pequeno artigo aonde aprofundo alguns desses elementos (Buitrago \& Braga, 2014a).
} 
desenhado em Bogotá e redesenhado em Havana em $1982 .{ }^{60}$ A identidade visual do Rio 84 é um jogo tipográfico no qual estão sendo ressaltadas as similaridades das línguas que compunham a associação: o português e o espanhol.

Usando cores que relacionassem a dimensão material da terra, o projeto brasileiro estava representando o substrato no qual foi plantada a semente e onde aprofundam-se as raízes: "verde e o marrom... a terra... a terra latino-americana; então eu tomei as cores da terra mais material, ainda aí a terra seja mais conceitual... a terra: território... a nossa terra como se diz" (Redig, 2013a).
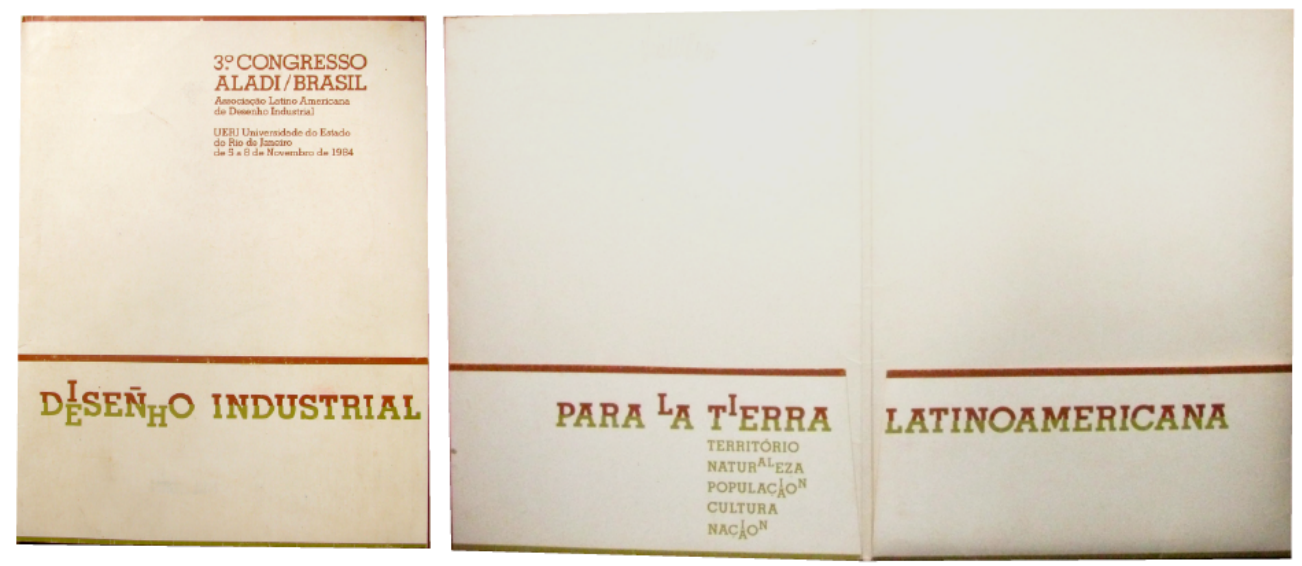

Figura 7. Capa da pasta do $3^{\circ}$ Congresso de ALADI, 1984. Projeto visual: Joaquím Redig (Brasil) Acervo Pessoal Marcos Braga (APMB)

$\mathrm{Na}$ explícita necessidade que expressaram os fundadores de ALADI em mostrar as semelhanças para consolidar a ilusão da Comunidade Imaginada, tanto a delimitação do território quanto o assinalamento da sua língua, constituem o sonho de confraternização de 'nossos povos'

[...] T(i)erra como nosso contexto de vida, como nossa realidade, $t$ (i)erra como nosso território, nossa natur(al)eza, nossa popula(ción)ção, nossa cultura, enfim, nossa na(ción)ção. T(i)erra como nossa fertilidade natural e cultural, t(i)erra como nossa história de sofrimento, exploração, e miséria, t(i)erra como nossa efusiva energia humana. Assim, diferenciadas mas integradas, como quisemos mostrar inclusive através da imagem visual de nosso encontro no Brasil (Redig, 1984, p. $3)$.

\footnotetext{
60 Santiago Pujol (Cuba) decidiu trabalhar uma reedição do projeto de Gámez com a ideia da continuidade. Dessa forma, usando o mesmo mapa, o mesmo sistema visual e o mesmo sistema estrutural, Pujol desenvolve mais alguns elementos, integrando o logo -a palavra ALADI- no mapa do Gámez (Pujol, 2015).
} 
Acho interessante que assim como no caso do território, as preocupações com a fusão entre as duas línguas também foram exploradas com antecedência na região. 0 argentino Xul Solar, explorou toda a sua vida um esotérico sistema linguístico Neocriollo- que representara a utopia da confraternização latino-americana na fusão entre o português e o espanhol. Como se estivesse parando na frente da proposta estadunidense, atualiza a forma como a Doutrina Monroe foi recebida na região. A panlíngua que tinha ser falada na Pan-América.

A sua herança cultural familiar com pais que provem não só de países externos à sua terra-natal Argentina, mas à raízes linguísticas diferentes entre eles -o pai era lituano a mãe italiana-, e as suas experiências e corredeiras pela Europa das primeiras décadas do século 20, são algumas condições sociais que podem explicar o seu interesse e destreza na língua

[...] Luego serre los oqos, i noai mas luzes. dige: "sou lu mas negro keas veido, i sou too luz, i mis nombres lux, es dize, xul al revéz". entón le digu: "¿sou tú o eres yo? si mi nombr'es el tuyo". él dige: "eres too, sou too cadauno es too". me arroibu en él, me le unu, mas luego me coxibu, i $\mathrm{pr}^{\prime}$ untu porké sou tan fiaco, tan tolo, tan meskino, porké olvidu nel mundo, i me'ponde: "te grafäré mi nombre nel pecho, ke te kemilembre" Trecho do Hexagrama 45. Xul Solar (Argentina) em 1925. (Schwartz, 2013, p. 157).

[...] Mi kerido tata: Esperaba ya este año volverme á la patria desde Londres. Envez estoi aquí desde ha poco i kedaré 2 ó 3 meses. Cansado de tanto salvajismo i atraso ke hai en Europa. Xul Solar (Argentina) entre 1919 e 1920 (Schwartz, 2013, p. 151).

Além dos detalhes na obra de Solar -que me parecem suficientemente bem trabalhados por Schwartz- a fixação na criação do Neocriollo, deixa ver o seu impulso em assinalar uma língua para o território. É claro, tanto a forma no sentido plástico, como a estrutura 'linguística' são notoriamente diferentes do caso de Redig. Como na comparação entre Gámez e Torres, tampouco me importo com essa questão. 0 que me parece inegável é o esforço que cada um faz para atribuir um código linguístico na América Latina do sonho. Um esforço aparentemente motivado pela mesma ideia apologética com a união latino-americana- sem importar o tempo ou o lugar. Umas solidariedades particulares -na fala de Anderson- como caraterísticas intrínsecas da língua com o objetivo de criar comunidades imaginadas (1993, p. 189), exploradas e visualmente traçadas no caso do regionalismo da América Latina. 
Em um parágrafo anterior afirmei que não achava que os latino-americanos presentes em Interdesign 78 simplesmente ativaram a consciência sobre as semelhanças dos problemas dos países da região ou repentinamente começaram a perceber os exercícios de intervenção dos países desenvolvidos nos assuntos latino-americanos a partir da experiência que oferecia aquele workshop no México. Como tinha tentado expor nestas paginas, tais ideias têm uma trajetória que aparentemente pode ser rastreada desde o século 19 na região. Uma trajetória que sugere que o sentido delas não parece ter mudado muito no passo do tempo, por vezes se mostrando fortalecida frente a ameaças externas e/ou acontecimentos, as vezes -como apologia a Marx'desmanchando no ar'.

\section{7.}

Princípios discricionais da Arquitetura Moderna definindo o seu papel social e o sentido do seu trabalho no contexto; concepções em torno da tecnologia como ferramenta para a conquista dos ideários modernos do bem-estar; teses, críticas e diálogos da CEPAL, do comunismo e das correntes de pensamento libertárias; visões sobre a pobreza, a solidariedade e a existência do Outro, como problematizadas pela Igreja Militante... todos esses elementos com mais outros tantos que não enxergo no momento, alimentam e são alimentados por aquele 'unionismo' regional de longa data. Fazendo meu o sentido do mote de Serge Gruzinski (2012), toda essa mistura ocorre dentro de uma espécie de "caixa de ressonância". Um caldeirão que mistura e une permanente de tudo aquilo que chega nele. Mas que -no sentido acústico- não só recebe determinados pulsos sonoros senão que também os amplifica, já não necessariamente como o pulso que ingressou, mas transformado pela sua mistura com os outros.

Essa caixa de ressonância, se estende no tempo até as primeiras décadas do século 19 quando parece ter sido criada. Um vívido pensamento latinoamericanista que transforma o sentido de todas aquelas características que mencionei nessas páginas sobre a criatividade social, o uso da tecnologia, a crítica econômica e social ao desenvolvimento e a ação social da Igreja Católica. Como caixa de ressonância é igualmente o cofre da autonomia. Dessa forma, qualquer empreendimento que use a união latino-americana como justificativa, parece mais uma desculpa para atualizar e realizar a conquista daquele ideal: a autonomia dessa exótica terra. 
A ideia de criar nas circunstâncias para as circunstâncias; o essencialismo justificando a união regional. As nossas necessidades... os nossos processos... o nosso orgulho. Tudo parece uma forma de alimentar a ideia da autonomia da comunidade. Desde a reivindicação linguística de Xul Solar durante os anos 1920 para assinar uma língua, passando pela vindicação gráfica de Torres Garcia nos anos 1940 quando da sentido ao território, e Osvaldo Guayasamín nos anos 1970 denunciando o terror do assédio, assim como o trânsito desse espírito em músicas da cultura popular, é interessante ver como esse discurso que justifica a existência do design na América Latina está suportado naquele sentido comum dos intelectuais latino-americanos que vem de longa data.

Antropofagia, essencialismo, circunstancialismo, nacionalismo, orgulho do popular... tudo aquilo em uma agitada mistura, em profundo hibridismo como diria Garcia-Canclini (2015)... tudo como atualizando o lamento de Gabriel Garcia Márquez convertido em poesia no tamanho daquela solidão

[...] Es comprensible que insistan en medirnos con la misma vara con que se miden a sí mismos, sin recordar que los estragos de la vida no son iguales para todos, y que la búsqueda de la identidad propia es tan ardua y sangrienta para nosotros como lo fue para ellos. La interpretación de nuestra realidad con esquemas ajenos sólo contribuye a hacernos cada vez más desconocidos, cada vez menos libres, cada vez más solitarios [...] ¿Por qué la originalidad que se nos admite sin reservas en la literatura se nos niega con toda clase de suspicacias en nuestras tentativas tan difíciles de cambio social? ¿Por qué pensar que la justicia social que los europeos de avanzada tratan de imponer en sus países no puede ser también un objetivo latinoamericano con métodos distintos en condiciones diferentes? [...] Este es, amigos, el tamaño de nuestra soledad. Discurso de recebimento do prémio Nobel em literatura. Gabriel García Márquez (Colômbia) em 1982 (GarcíaMárquez, 2014). 